Methotrexate versus Azathioprine in rheumatoid arthritis

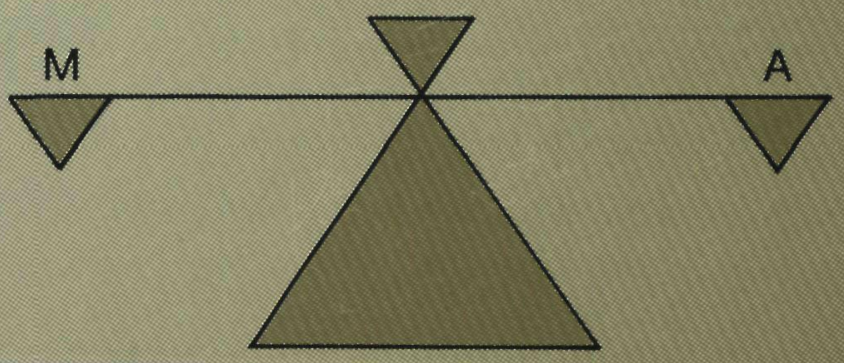

Maurice E.C. Jeurissen 

METHOTREXATE VERSUS AZATHIOPRINE

IN RHEUMATOID ARTHRITIS 



\title{
METHOTREXATE VERSUS AZATHIOPRINE IN RHEUMATOID ARTHRITIS
}

Een wetenschappelijke proeve op het gebied van de medische wetenschappen, in het bijzonder de geneeskunde

\section{PROEFSCHRIFT}

TER VERKRUGING VAN DE GRAAD VAN DOCTOR AAN DE KATHOLIEKE UNIVERSITEIT NIJMEGEN, VOLGENS BESLUIT VAN HET COLLEGE VAN DECANEN

IN HET OPENBAAR TE VERDEDIGEN

OP MAANDAG 2 DECEMBER 1991

DES NAMIDDAGS TE 1.30 UUR PRECIES

\author{
door \\ MAURITIUS EUGENIUS CAROLUS JEURISSEN
}

geboren op 31 augustus 1953 te Eindhoven 
PROMOTORES :

Prof. Dr. L.B.A. van de Putte

Prof. Dr. F.W.J. Gribnau

CO-PROMOTOR:

Dr. A.M.Th. Boerbooms

ISBN 90-90(0)4583-X

The studies presented in this thesis were performed in the Department of Rheumatology (Head: Prof. Dr. L.B.A van de Putte), University Hospital Nijmegen, The Netherlands.

The investigations were financially supported by a grant from the Dutch League against Rheumatism ('Het Nationaal Reumafonds').

Financial support by the Dutch League against Rheumatism ('Het Nationaal Reumafonds'), Inpharzam, Sarva-Syntex and Sterling Winthrop for the printing of this thesis is gratefully acknowledged. 
Niemand is verder van de waarheid dan hij die alle antwoorden al weet

Tsoeang Tsee

voor Wanneke

ter herinnering aan mijn vader 
CONTENTS

\section{CHAPTER 1 GENERAL INTRODUCTION}

1.1 Criteria and course of disease (i.c. rheumatoid arthritis) 3

1.2 Pathogenesis

1.3 Cytotoxic drugs and rheumatoid arthritis

1.4 Aim of the thesis

\section{CHAPTER 2 AZATHIOPRINE}

2.1 Chemistry, absorption, distribution, metabolism, 15

2.2 Mechanism of drug resistance 17

2.3 Mechanism of action 18

$\begin{array}{lll}2.4 & \text { Drug interactions } & 19\end{array}$

2.5 Dosage of AZA 19

2.6 Controlled clinical trials of AZA 19

2.7 Long-term experience 23

2.8 Adverse reactions 23

2.9 Fertility, pregnancy, lactation 24

2.10 Neoplasms 25

\section{CHAPTER 3 METHOTREXATE}

3.1 Chemistry, transport, polyglutamation 33

3.2 Absorption, distribution, metabolism, excretion 33

3.3 Mechanism of action 36

3.4 Drug interactions 36

3.5 Dosage of MTX 36

3.6 Leucovorin 36

3.7 Controlled clinical trials of MTX 37

3.8 Long-term experience 37

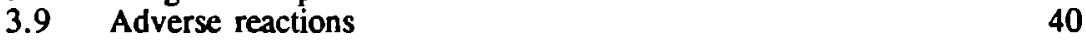

3.10 Felty's syndrome $\quad 43$

3.11 Fertility, pregnancy, lactation 44

3.12 Neoplasms 44

CHAPTER 4 METHOTREXATE THERAPY IN CONNECTIVE TISSUE DISEASES: A REVIEW OF THE LITERATURE

4.1 Abstract 53

4.2 Introduction 53

4.3 History 53

4.4 Animal studies 54

4.5 Hypothesis concerning the mechanism of action 54

4.6 Pharmacology and pharmacokinetics of MTX 55

4.7 Dosage of MTX 56

4.8 Clinical application of MTX: use in rheumatoid arthritis 56

4.8.1 Methotrexate and poly- and dermatomyositis 57

4.8.2 Methotrexate and systemic lupus erythematosus 58 
4.8.3 Methotrexate and scleroderma, sjögren's syndrome, mixed connective tissue disease

4.8.4 Methotrexate and vasculitis 59

4.9 Risk factors, drug interactions and adverse reactions 60

4.10 Conclusions and recommendations

CHAPTER 5 METHOTREXATE IN REFRACTORY RHEUMATOID ARTHRITIS

5.1 Abstract

5.2 Introduction

71

5.3 Patients and methods: $\quad 71$

- patients

- administration of MTX

71

- clinical assessments

72

- laboratory assessments

73

- HLA typing

- statistical analysis

5.4 Results:

- patients and study course

- effects on disease

- changes in serologic tests

- toxicity

5.5 Discussion

CHAPTER 6

METHOTREXATE VERSUS AZATHIOPRINE IN THE TREATMENT OF RIIEUMATOID ARTHRITIS.

\section{A FORTY-EIGHT-WEEK RANDOMIZED, DOUBLE-BLIND TRIAL}

6.1 Abstract 83

6.2 Introduction 83

6.3 Patients and methods: $\quad 84$

- patients $\quad 84$

- study design $\quad 84$

- medication regimens 85

- clinical assessment 85

- adverse reactions and withdrawals from the study 86

- laboratory assessment $\quad 86$

$\begin{array}{ll}\text { - statistical analysis } & 86 \\ 6.4 \text { Results: } & 87\end{array}$

- patient characteristics $\quad 87$

- efficacy in patients who received the same drug $\quad 87$ for 24 weeks and for 48 weeks

- efficacy as assessed by intention-to-treat analysis 90 at weeks 24 and 48 percentage improvement in disease variables and clinical response

- time to response 91

- effects on serologic and immunologic variables 93

- dosage of the trial medication, and treatment with 93 NSAIDs and corticosteroids

- adverse reactions 
CHAPTER 7 INFLUENCE OF METHOTREXATE AND AZATHIOPRINE ON RADIOLOGIC PROGRESSION IN RHEUMATOID ARTHRITIS.

\section{A RANDOMIZED, DOUBLE-BLIND STUDY}

7.1 Abstract

103

7.2 Introduction

103

7.3 Patients and methods:

-patients

-study design and medication

-clinical assessments

-radiographic assessment

-statistical analysis

7.4 Results -clinical response to therapy -radiologic response to therapy

7.5 Discussion

CHAPTER 8 SERIAL PULMONARY FUNCTION TESTS DURING A RANDOMIZED, DOUBLE-BLIND TRIAL OF AZATHIOPRINE VERSUS METHOTREXATE IN RHEUMATOID ARTHRITIS

8.1 Abstract

8.2 Introduction

8.3 Patients and methods: -patients -pulmonary function tests -statistical analysis

8.4 Results

8.5 Discussion

CHAPTER 9 RARE SIDE EFFECTS OF AZATHIOPRINE AND METHOTREXATE

9.1 Pancytopenia related to azathioprine in rheumatoid

9.2 Azathioprine induced fever, chills, rash, and

9.3 Pancytopenia and methotrexate with trimethoprim-

9.4 Eruption of nodulosis and vasculitis during methotrexate therapy for rheumatoid arthritis 


\section{ABBREVIATIONS}

ADA $\quad=$ adenosine deaminase

AICAR = aminoimidazole carboxamide ribonucleotide

AMP = adenine monophosphate

AMPS = adenylosuccinic monophosphate

APRT = adenine phosphoribosyl transferase

ATP = adenine triphosphate

AZA = azathioprine

DNA = deoxyribonucleic acid

FAICAR = formyl aminoimidazole carboxamide ribonucleotide

FGAR = formylglycinamide ribonucleotide

FH4 = tetrahydrofolate

$\mathrm{FH} 2 \quad=$ dihydrofolate

GAR = glycinamide ribonucleotide

GMP = guanine monophosphate

HGPRT = hypoxanthine guanine phosphoribosyl transferase

IMP = inosinic monophosphate

6-MP = 6 mercaptopurine

6-MMPR $=6$ methylmercaptopurine riboside

6-MPR $=6$ mercaptopurine riboside

MTX = methotrexate

PNP = purine nucleoside phosphorylase

PNT $=$ purine 5 nucleotidase

5 PRA $=5$ phosphoribosylamine

PRPP = phosphoribosyl pyrophosphate

RNA = ribonucleic acid

TGDP = thioguanine diphosphate

TGMP = thioguanine monophosphate

TGN= thioguanine

TGTP = thioguanine triphophate

TdGTP = deoxy-thioguanine triphosphate

TIMP = thioinosinic monophosphate

dTMP = deoxy-thymidylate monophosphate

TPMT = thiopurine methyltransferase

TXMP = thioxanthine monophosphate

dUMP = deoxy-uridylate monophosphate

$\mathrm{XAO}=$ xanthine oxydase

XMP $=$ xanthine monophosphate 
Chapter 1

GENERAL INTRODUCTION 

RHEUMATOID ARTHRITIS (RA) is a chronic multi-systemic and articular inflammatory disorder of unknown origin. The association between RA and the human leucocyte antigen (HLA) DR4 suggests an inherited susceptibility $(1,2)$. Women are affected two to three times more often than men (3). Rheumatoid arthritis may occur at any age, but it is generally agreed that its prevalence increases with advancing age (3).

\subsection{CRITERIA AND COURSE OF DISEASE}

The criteria for the classification of RA have recently been revised (4). A patient is said to have RA if at least four of seven criteria at least during 6 weeks are met (Table 1). Besides joint symptoms and systemic features (such as fatigue, fever, anemia and weight loss), extra-articular features e.g. subcutaneous nodules, pleuropulmonary lesions and signs of vasculitis are relatively common manifestations of RA.

There are roughly three patterns of articular course in RA. Firstly the monocyclic disease course in approximately $20 \%$ of patients. Secondly the intermittent, polycyclic course present in about $70 \%$ of patients and characterized by exacerbations and remissions. Thirdly the progressive form in about $10 \%$ of cases (2). This latter disease course is characterized by the development of destructive polyarthritis and frequent presence of extra-articular manifestations leading to considerable disability.

Several factors are considered to be associated with a less favorable clinical outcome: appearance of subcutaneous nodules, impaired functional capacity after one year of disease, presence of rheumatoid factor, antiperinuclear factor in rheumatoid factornegative patients, persistently increased erythrocyte sedimentation rate (ESR) or Creactive protein $(\mathrm{CRP})$, persistently low haemoglobin $(\mathrm{Hb})$, and HLA-DR4 $(5,6,7,8)$.

\subsection{PATHOGENESIS}

Despite extensive research, the cause of RA is still unknown. It is generally accepted that the presentation of an unknown antigen (stimulus) to a genetically susceptible individual can trigger RA (9). The responsible arthritogenic stimulus is unknown. Recently there is renewed interest in some infectious agents such as the Epstein-Barr virus and the mycobacteria (9).

The sequence of pathological processes in RA can be divided into five stages (9): The first stage is characterized by antigen presenting (via macrophages or dendritic cells) to the T-lymphocytes. The second by proliferation of $\mathrm{T}$ - and B-lymphocytes and the development of new blood vessels (neo-angiogenesis) in the synovial membrane. In this stage B-lymphocytes are stimulated, via soluble mediators (=cytokines, produced by activated macrophages and lymphocytes) to secrete immunoglobulins and rheumatoid factor. This rheumatoid factor forms large immune complexes, which activate the complement system leading to a cascade of inflammatory events. Retained immune complexes localized in cartilage and intra-articular ligaments (10), may play an important role in the chronicity of the rheumatoid inflammation $(11,12)$. In the third stage neutrophils accumulate in the synovial fluid and synovial cells proliferate markedly. In the fourth stage vascular and granulation tissue (pannus) arise from the synovial membra- 
Table 1. Criteria for the classification of Rheumatoid Arthritis (see also reference 4)
1. Morning stiffness lasting at least one hour
2. Arthritis of three or more joint areas *
3. Arthritis of hand joints \#
4. Symmetric arthritis $\$$
5. Rheumatoid nodules
6. Presence of theumatoid factor **
7. Radiographical changes $@$

- The 14 possible areas are; right or left proximal interphalangeal (PIP) joints, metacarpophalangeal (MCP) joints, wrist, elbow, knee, ankle, and metatarsophalangeal (MTP) joints.

\# Wrists, PIPs, or MCPs.

$\$$ Regarding the joint areas mentioned in the second criterium.

** By any method of which the result has been positive in $<5 \%$ of normal control subjects.

(1) These must include erosions or periarticular decalcification on hand or wrist radiographs.

ne and invade the cartilage starting from the margin. In the fifth stage there is more invasion and destruction of cartilage, while intra-articular ligaments and subchondral bone are also affected. Several enzymes such as collagenase (13) and cytokines such as interleukin-1 play a part in cartilage and bone destruction $(14,15,16)$. From stage 2 to stage 5 symptoms and clinical findings increase. Radiographically, erosions and narrowing of joint space are found in stage 5 .

The important role of T-lymphocytes $(17,18)$ in the pathogenesis of RA is reflected by several observations: Firstly, the immunohistological examination of the synovium in RA has demonstrated vast infiltration of lymphocytes. The majority of these cells are $T$ helper (CD4) cells $(19,20)$. Secondly, activation of T-lymphocytes is thought to occur after binding to the antigen presenting cell, which bears certain major histocompatibility (MHC) class 2 molecules associated with susceptibility to RA (9). Thirdly, several therapies used to diminish T-lymphocytes such as lymphapheresis $(21,22)$, thoracic duct drainage $(23,24)$, and total lymphoid irradiation $(17,25,26,27)$, have been reported to be effective in RA.

Clinically, B-cell proliferation in RA is reflected by the presence of rheumatoid factor and (polyclonal) elevated immunoglobulins. Decreased levels of C3 and C4 intra-articularly indicate complement activation.

In the next section of this chapter we shall discuss the question in which way cytotoxic drugs as azathioprine (AZA) and methotrexate (MTX) may interfere in the above mentioned processes of rheumatoid inflammation.

\subsection{CYTOTOXIC DRUGS AND RHEUMATOID ARTHRITS}

As mentioned before, RA consists of a complex process of immune and inflammatory events. Cytotoxic drugs as AZA and MTX are supposed to have (non-specific) antiinflammatory and immunosuppressive properties (28). It is generally accepted to treat RA patients with these drugs when there are features of progressive disease course such as a) 
persistently active synovitis despite treatment with so-called first line antirheumatic drugs (=non-steroidal anti-inflammatory drugs (NSAIDs) combined with second-line drugs as hydroxychloroquine, parenteral gold and/or D-penicillamine, b) development of (severe) radiologic progression, c) development of extra-articular manifestations as vasculitis (29).

The anti-inflammatory properties of AZA and MTX have been established in animal $(30,31,32)$ and human studies $(28,33,34,35)$. From the late sixties, AZA has been used by many investigators on the assumption that the drug suppressed immunological processes (36). However, despite apparent clinical benefit in autoimmune diseases, clear immunosuppression could not be demonstrated $(36,37)$. To our knowledge studies in RA patients such as recently performed for MTX about its effect on, e.g. chemotaxis, cytokines, neoangiogenesis etc., are lacking for AZA. In one open study of AZA versus cyclosporin in RA no significant changes in subsets of T-cells (CD4:CD8 ratio) were found after 24 weeks of AZA therapy (38). Furthermore there are conflicting data about the effect of AZA on theumatoid factor and immunoglobulins (Chapter 2). Many data on an anti-inflammatory effect of AZA derive from animal experiments.

Table 2. Animal studies and the influence of low-dose methotrexate

\begin{tabular}{|c|c|c|c|c|}
\hline Effect & Animal & $\begin{array}{l}\text { Dosage MTX } \\
\text { (mg/kg/day) }\end{array}$ & Author & (Ref) \\
\hline $\begin{array}{l}\text { Suppression of adjuvant } \\
\text { (AA)/ streptococcal } \\
\text { cell wall } \\
\text { arthritis (SCW) }\end{array}$ & $\begin{array}{l}\text { rat }(\mathrm{AA}) \\
\text { rat }(\mathrm{AA}) \\
\text { rat }(\mathrm{SCW}) \\
\text { rat }(\mathrm{AA}) \\
\text { rat }(\mathrm{AA})\end{array}$ & $\begin{array}{l}0.10-5.0^{*} \\
0.15-0.6 \\
0.13-0.03 \\
0.30 \\
0.13-0.06\end{array}$ & $\begin{array}{l}\text { Ward } \\
\text { Welles } \\
\text { Ridge } \\
\text { Johnson } \\
\text { Ridge }\end{array}$ & $\begin{array}{l}(30) \\
(41) \\
(42) \\
(43) \\
(44)\end{array}$ \\
\hline $\begin{array}{l}\text { Retardation of joint } \\
\text { destruction }\end{array}$ & rat & $0.13-0.03$ & Ridge & (44) \\
\hline $\begin{array}{l}\text { Suppression of influx } \\
\text { of macrophages into } \\
\text { synovium }\end{array}$ & rat & $0.13-0.25$ & $\mathrm{Hu}$ & (45) \\
\hline $\begin{array}{l}\text { Inhibition of chemo- } \\
\text { taxis (induced by LB4) } * *\end{array}$ & mice & 0.25 & Suarez & (46) \\
\hline $\begin{array}{l}\text { Decrease of IL-1 syn- } \\
\text { thesis }\end{array}$ & $\begin{array}{l}\text { rat } \\
\text { rat }\end{array}$ & $\begin{array}{l}0.13-0.25 \\
0.30\end{array}$ & $\begin{array}{l}\text { Hu } \\
\text { Johnson }\end{array}$ & $\begin{array}{l}(45) \\
(43)\end{array}$ \\
\hline $\begin{array}{l}\text { Suppression of proli- } \\
\text { feration and maturation } \\
\text { of B-lymphocytes }\end{array}$ & mice & $\begin{array}{l}10^{-7} \text { to } 10^{-8} \\
\text { Mol \# }\end{array}$ & Rosenthal & $(47)$ \\
\hline
\end{tabular}

* $0.125 \mathrm{mg} / \mathrm{kg} /$ day methotrexate (MTX) in mice or rats is analogous to $8.75 \mathrm{mg}$ MTX weekly in humans.

** LB4 means leukotriene B4

\# A solution of $10^{-7}$ to $10^{-1} \mathrm{Mol}$ MTX was added to mouse cell cultures (in-vitro study). A concentration of $10^{-1} \mathrm{Mol}$ is analogous to the serum MTX levels in RA patients 24 hours after ingestion of 7.5-15 $\mathrm{mg}$ MTX. 
Table 3. Effects of low-dose methotrexate (MTX) in human studies (RA patients)

\begin{tabular}{|c|c|c|c|c|}
\hline Effect & $\begin{array}{l}\text { In vivo } \\
\text { In vitro }\end{array}$ & $\begin{array}{l}\text { Dosage MTX } \\
\text { (mg/week } \\
\text { orally or i.m) }\end{array}$ & Author & (Ref) \\
\hline $\begin{array}{l}\text { Inhibition of LB4 } \\
\text { synthesis }\end{array}$ & in vitro & $5.0-15.0$ & Sperling & (48) \\
\hline $\begin{array}{l}\text { Decrease of chemotactic } \\
\text { migration of leucocytes }\end{array}$ & in vitro & 10.0 & O'Callagh. & (49) \\
\hline $\begin{array}{l}\text { Decrease of IgM-Rf } \\
\text { synthesis }\end{array}$ & $\begin{array}{l}\text { in vitro } \\
\text { in vivo }\end{array}$ & $\begin{array}{l}7.5-12.5 \\
7.5-15.0\end{array}$ & $\begin{array}{l}\text { Olsen } \\
\text { Alarcớn }\end{array}$ & $\begin{array}{l}(50) \\
(51)\end{array}$ \\
\hline $\begin{array}{l}\text { Decrease of IL-1 * } \\
\text { activity }\end{array}$ & $\begin{array}{l}\text { in vitro/ } \\
\text { in vivo }\end{array}$ & $10.0-15.0$ & Segal & (52) \\
\hline $\begin{array}{l}\text { Antiproliferative } \\
\text { effect: endothelial } \\
\text { cells more inhibited } \\
\text { than synovial fibro- } \\
\text { blasts \# }\end{array}$ & in vitro & $\begin{array}{l}10^{-9} \text { to } 10^{-7} \\
\text { Mol }\end{array}$ & Hirata & (53) \\
\hline $\begin{array}{l}\text { Decrease of immuno- } \\
\text { globulins }\end{array}$ & $\begin{array}{l}\text { in vivo } \\
\text { in vivo }\end{array}$ & $\begin{array}{l}7.5-15.0 \\
7.5-25.0\end{array}$ & $\begin{array}{l}\text { Boerbooms } \\
\text { Andersen }\end{array}$ & $\begin{array}{l}\text { (54) } \\
\text { (55) }\end{array}$ \\
\hline $\begin{array}{l}\text { Decrease of enzymes } \$ \\
\text { (collagenase }>\text { elastase) }\end{array}$ & in vitro & $7.5-12.5$ & Martel & (13) \\
\hline
\end{tabular}

- IL-1 means interleukin-1; IL-1 synthesis was not inhibited.

\# The effect of MTX in various concentrations added to cell cultures was studied. Inhibition of DNA synthesis of human umbilical vein endothelial cells in vitro and rabbit comeal neovascularization was studied. DNA synthesis of fibroblasts obtained from RA synovium was also measured. Neovascularization plays an important part in the formation of pannus in RA.

$\$$ Neutral protease activity was measured in cartilage and synovial membrane obtained from RA patients. These enzymes are involved in the process of cartilage matrix degradation.

Probably due to the great interest in treatment of RA patients with low-dose MTX the last decade, many studies were published about possible mechanisms of action of MTX in RA. As Tables 2 and 3 show, the effects of MTX possibly implicated in the treatment of RA, are highly divergent. In addition, high-dose intravenous MTX $\left(500 \mathrm{mg} / \mathrm{m}^{2}\right)$ followed by leucovorin rescue, given in 5 RA patients, was associated with a distinct reduction of circulating activated $T$-lymphocytes i.e. decrease in surface $D R$ expression on lymphocytes (39). Whether the observed change should be ascribed to a direct effect on T-cells or may reflect a recirculation pattern rather than total body alteration is unknown. Since the many cell types involved, interact with one another in a complex manner, there is intertwining of anti-inflammatory and immunosuppressive events. Therefore, it may be difficult to characterize a certain effect of a drug i.c of AZA or MTX as merely anti-inflammatory or immunosuppressive (40). Probably it would be better to call drugs such as MTX and AZA "immunoregulatory drugs" rather than "immunosuppressive" or cytotoxic drugs (40). 
In summary, animal and human in vivo and in vitro studies suggest that low-dose MTX has anti-inflammatory, subtle immunomodulating and antiproliferative properties (Table 2 and 3). The exact mechanism of action of this drug remains however unclear. This thesis is mainly concemed with clinical aspects rather than with mechanism of action of therapy with AZA or MTX.

\subsection{AIM OF THE THESIS}

The major objective of this thesis was to determine the place of methotrexate in the therapy of rheumatoid arthritis. In order to justify its increasing use in RA, a comparison was made with another immunoregulatory drug, azathioprine. As a variant on the treatment pyramid (56) for RA, in Figure 1 a scheme is presented in which the successive treatment steps in RA are illustrated. Onset of clinical response, short- and long-term efficacy, toxicity profile, and long-term safety are important factors in determining a place for the different antirheumatic drugs. Apart from these factors, degree of disease activity in a RA patient, presence and/or development of radiologic abnormalities, and other reasons as known drug allergy (e.g. to sulfonamides) may influence the final choice for a specific antirheumatic drug.

Chapters 2, 3 and 4 are review articles: In Chapter 2 general data (pharmacology, clinical trials in RA, adverse reactions etc.) about azathioprine and in Chapter 3 general data about methotrexate are reviewed. In Chapter 4 the use of methotrexate in connective tissue diseases is described.

Thereafter results from an open trial (Chapter 5) and a double-blind trial (Chapter 6, 7, $8,9)$ will be discussed. The following topics and questions will be dealt with:

- Is methotrexate effective in refractory RA, i.e. in RA patients with therapeutic failure or intolerance to the next anti-rheumatic drugs: hydroxychloroquine, parenteral gold, D-penicillamine and azathioprine? (Chapter 5)

- Are there differences in clinical results between RA patients treated with MTX or azathioprine, who were unresponsive to or react with toxicity to parenteral gold, Dpenicillamine or both drugs? The efficacy, toxicity and influence on seroimmunological parameters are described in a double-blind comparative trial of 64 RA patients (Chapter 6)

- Are there differences between radiographic results of RA patients who start on AZA or on MTX after one year of therapy? Is there difference in slowing of radiographic progression? (Chapter 7 )

- What kind of pulmonary abnormalities are found in a patient group with refractory RA? Are there changes in chest radiographs or results of pulmonary function tests during therapy with AZA or MTX? Is serial pulmonary function testing useful for monitoring MTX pulmonary toxicity? (Chapter 8)

In Chapter 9 four rare, but dangerous side effects of AZA and MTX are described in more detail. Three of these four adverse reactions occurred during the double-blind trial: 
pancytopenia due to AZA, severe hypersensitivity reactions due to AZA, and eruption of nodulosis related to MTX. Pancytopenia due to the combined use of MTX and other antifolate drugs is described in a fourth article of this chapter. Chapter 10 comprises final conclusions and the summary of this study.

Figure 1. Scheme of the different steps in the treatment of rheumatoid arthritis.

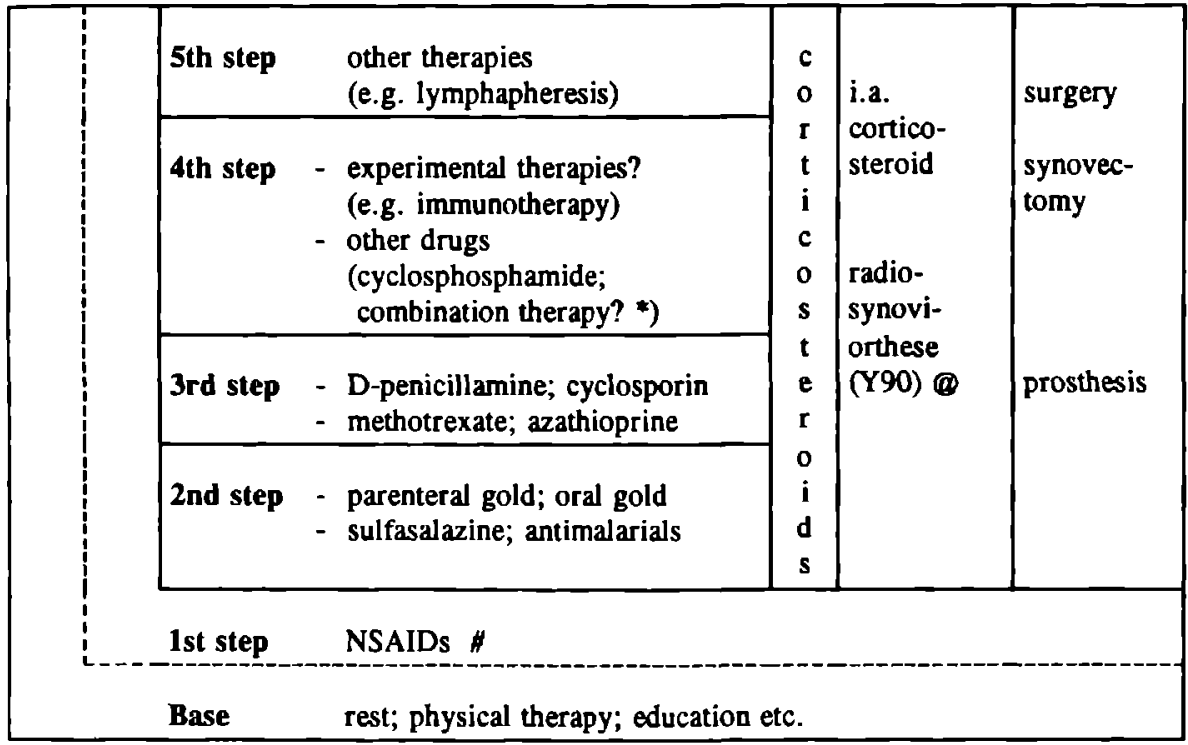

* For example parenteral gold + antimalarials

* Non-steroidal anti-inflammatory drugs

(1) Synovial irradiation by ytarium-90 silicate intra-articulary

\section{REFERENCES}

1. Wordsworth $P$. The immunogenetics of Rheumatoid Arthritis. Current Opinion in Rheumatology 1990; 2: 243-249.

2. Morel PA, Fatman CG. Immunogenetics of rheumatoid arthritis. J Rheumatol. 1989; 16: 422-423.

3. Masi AT, Medsger THA. Epidemiology of the rheumatic diseases. In: Arthritis and allied conditions. Mc Arthy DJ. Lea \& Febiger, Philadelphia 1989; 11 th ed: Ch 3.

4. Amett FC, Edworthy SM, Bloch DA, McShane DJ, Fries JF, Cooper NS. The American Rheumatism Association 1987 revised criteria for the classification of rheumatoid arthritis. Arthritis Rheum. 1988; 31: 315-324.

5. Van der Heyde DM, van Riel PL, van Rijswijk MH, van de Putte LBA. Influence of prognostic features on the final outcome in rheumatoid arthritis. A review of the literature Seminars Arthritis Rheum. 1988; 17: 284-292. 
6. Reilly PA, Cosh JA, Maddison PJ, Rasker JJ, Silman AJ. A 25 year prospective study of 100 patients. Ann Rheum Dis 1990; 49: 363-369.

7. Westgeest AA, Boerbooms AM, Jongmans M, Vandenbroucke JP, Vierwinden G, van de Putte LB. Antiperinuclear factor, indication of more severe disease in seronegative rheumatoid arthritis. J Rheumatol 1987; 14: 893-897.

8. Calin A, Elswood J, Klouda PT. Destructive arthritis, rheumatoid factor and HLA-DR4. Arthritis Rheum 1989; 32: 1121-1125.

9. Harris ED. Rheumatoid Arthritis. Pathophysiology and Implications for therapy. N Engl J Med 1990; 322: 1277-1289.

10. Cooke TD, Hurd ER, Jasin HE, Bienenstock J. Identification of immunoglobulins and complement in rheumatoid articular collageneous tissues. Arthritis Rheum. 1975; 18: 541545.

11. Cooke TD, Hurd ER, Ziff M. The pathogenesis of chronic inflammation in experimental antigen-induced arthritis.II. Preferential localization of antigen-antibody complexes to collageneous tissues. J Exp Med 1972; 135: 323-338.

12. Boerbooms AM, van den Broek WJ, Van Rens TJ, van de Putte LB. 99Tc pertechnetate uptake after total knee replacement in rheumatoid arthritis. Acta Orthop Scand 1982; 53: 125-129.

13. Martel-Pelletier J, Cloutier J, Howell DS, Pelletier J. Human rheumatoid arthritis cartilage and its neutral proteoglycans degradins proteases. The effects of antirheumatic drugs. Arthritis Rheum. 1985; 28: 405-412.

14. Pettipher ER, Higgs GA, Henderson B. Interleukin-1 induces leucocyte infiltration and cartilage proteoglycan degradation in the synovial joint. Proc Natl Acad Sci USA 1986; 82: 8749-8753.

15. Van den Berg WB, van de Loo FA, Zwarts WA, Otterness IG. Effects of murine recombinant interleukin-1 on intact homologous articular cartilage: a quantitative and autoradiographic study. Ann Rheum Dis 1988; 47: 855-863.

16. Miyaska N, Sato K, Goto M, Sasano M, Natsuyama M, Inoue K. Augmented interleukin-1 production and HLA-DR expression in the synovium of rheumatoid arthritis patients. Possible involvement in joint destruction. Arthritis Rheum 1988; 31: 480-486.

17. Gaston JSH, Strober S, Solovera JJ, Gandonz D, Lane N, Schurmann D et al. Dissection of the mechanism of immune injury in rheumatoid arthritis, using total lymphoid irradiation. Arthritis Rheum 1988; 31: 21-30.

18. Breedveld FC, de Vries RRP. Possibilities for the immunotherapy of rheumatoid arthritis. Clin Rheum 1990; 9: 171-179.

19. Meijer CJLM, van de Putte LBA, Eulderink F, Kleinjan R, Lafeber GJM, Bots GThAM. Characteristics of mononuclear cell populations in chronically inflamed synovial membranes. J Path 1977; 121: 1-8.

20. Duke OL, Panayi GS, Janosny G, Poulter LW. An immunohistological analysis of lymphocyte subpopulations and their micro-environment in the synovial membranes of patients with rheumatoid arthritis using monoclonal antibodies. Clin Exp Immunolog $1982 ; 49 ; 22-30$.

21. Karsh J, Klippel SH, Plotz PH, Decker JL, Wright DR. Lymphapheresis in rheumatoid arthritis: a randomized trial. Arthritis Rheum 1981; 24: 867-873.

22. Boerbooms AMTh, de Rooy DJRAM, Geerdink PJ, van de Putte LBA, van den Ouweland F. Lymphapherese as compared with rest period in treatment of severe rheumatoid arthritis. Clin Rheum 1984; 31: 21-27.

23. Paulus HE, Machleder HI, Levine S, Yu DJY, MacDonald WS. Lymphocyte involvement in rheumatoid arthritis: studies during thoracic duct drainage. Arthritis Rheum 1977; 20: 1249-1262.

24. Ueo T, Tanaka S, Tominaga Y, Ogawa H, Sakurami T. The effect of thoracic duct drainage on lymphocyte dynamics and clinical symptoms in patients with rheumatoid arthritis. Arthritis Rheum 1979; 22: 703-709.

25. Strober S, Tanay A, Field E, Hoppe RT, Calin A, Englemann EG. Efficacy of total lymphoid irradiation in intractable rheumatoid arthritis: a double-blind, randomized trial. Ann Intern Med 1985; 102: 441-449.

26. Trentham DE. Clinical and immunological effects of fractionated total lymphoid irradiation in refractory rheumatoid arthritis. N Engl J Med 1981: 305: 976-982.

27. Tanay A, Field EH, Hope RT, Strober S. Long-term follow-up of rheumatoid arthritis treated with total lymphoid irradiation. Arthritis Rheum 1987; 30: 1-10.

28. Hurd ER. Immune suppressive and anti-inflammatory properties of cyclophosphamide, 
azathioprine and methotrexate. Arthritis Rheum 1973; 16: 84-88.

29. Barnes CG. The choice of, and the decision to apply disease modifying drugs. Ann Rheum Dis 1982; 41: 1-2 (Suppl).

30. Ward JR, Cloud S, Krawitt EL, Jones RS. Studies on adjuvant-induced polyarthritis in rats. III. The effect of "immunosuppressive agents" on arthritis and tuberculin hypersensitivity. Arthritis Rheum 1964; 7: 654-661.

31. Stevens JE, Willoughby DA. The anti-inflammatory effect of some immunosuppressive agents. J Path 1969; 97: 367-373.

32. Currey HLF. A comparison of immunosuppressive and anti-inflammatory agents in the rat. Clin Exp Immunolog 1971; 9: 879-887.

33. Mitchell MS, Wade ME, De Conti RC, Bertino JR, Calabresi P. Immunosuppressive effects of cytosine arabinoside and methotrexate in man. Ann Intern Med 1969; 3: 535545.

34. Johnston WJ, Russell AS, Kovithavongs Th, Dasgupta M. Measures of immunologic and inflammatory responses in vitro in rheumatoid patients treated with methotrexate. J Rheumatol 1986; 13: 294-296.

35. Furst DE, Kremer JM. Methotrexate in rheumatoid arthritis. Arthritis Rheum 1988; 31: 305-314.

36. Denman EJ, Denman AM, Greenwood BM, Gall M. Failure of cytotoxic drugs to suppress immune responses of patients with rheumatoid arthritıs. Ann Rheum Dis 1970: 29: 220-231.

37. Ten Berge RJM, Schellekens PTH. A critical analysis of the use azathioprine in clinical medicine. Neth J Med 1983; 26: 167-171.

38. Förre O, Bjerkhoel F, Salvesen Ch F, Berg KJ. An open controlled randomized comparison of cyclosporin and azathioprine in the treatment of rheumatoid arthritis. Arthritis Rheum 1987: 30: 88-92.

39. Shiroky J, Allegra C, Inghirami G, Chabner B, Yarboro Ch, Klippel JH High-dose intravenous methotrexate with leucovorin rescue in rheumatoid arthritis. $J$ Rheumatol 1988; 15: 251-255.

40. Decker JL, Steinberg AD. Immunoregulatory drugs. In: Arthritis and allied conditions. A Textbook of Rheumatology. McArthy DJ. Lea \& Febiger. Philadelphia, London. 10th ed: Ch 33. 1985.

41. Welles WL, Silkworth J, Oronsky AL, Kerwar SS. Studies on the effects of low-dose methotrexate on rat adjuvant arthritis. J Rheumatol 1985; 12: 904-906.

42. Ridge SC, Rath N, Galivan J, Zabriski J, Oronsky AL, Kerwar SS. Studies on the effects of D-penicillamine, goldthioglucose and methotrexate on streptococcal cell wall arthritis. J Rheumatol 1986; 13: 895-898.

43. Johnson WJ, Dimartino MJ, Meunier PC, Muirhead KA, Hanna N. Methotrexate inhibits macrophage activations as well as intravascular and cellular inflammatory events in rat adjuvant induced arthritis. J Rheumatol 1988; 15: 745-749.

44. Ridge SC, Ferguson KM, Rath N, Galivan J, Freisheim JH, Oronsky AL. Methotrexate suppresses passive adjuvant arthritis: Studies on the metabolism of methotrexate in mononuclear cells derived from normal and adjuvant arthritic rats. J Rheumatol 1988; 15: 1193-1197.

45. Hu SK, Mitcho Y, Oronsky AL, Kerwar SS. Studies on the effect of methotrexate on macrophage function. J Rheumatol 1988; 15: 206-209.

46. Suarez CR, Pickett WC, Bell DH, McClintock DK, Oronsky AL, Kerwar SS. Effects on low-dose methotrexate on neutrophil chemotaxis induced by leukotriene B4 and C5a. J Rheumatol 1987; 14: 9-11.

47. Rosenthal GJ, Weigand GW, Germolic DR, Blank JA, Luster MI. Suppression of B-cell function by methotrexate and trimetrexate. J Immunolog 1988; 141: 410-416.

48. Sperling RI, Coblyn JS, Larken JK, Benincaso AI, Austin KF, Weinblatt ME. Inhibition of leukotriene B4 synthesis in neutrophils from rheumatoid arthritis patients treated with methotrexate. Arthritis Rheum 1990; 33: $1149-1155$.

49. O'Callaghan JW, Forrest MJ, Brooks PM. Inhibition of neutrophil chemotaxis in methotrexate treated patients. Rheumatol Intern 1988; 8: 41-45.

50. Olsen NJ, Callahan LF, Pincus Th. Immunologic studies of rheumatoid patients treated with methotrexate. Arthritis Rheum 1987; 30: 481-488.

51. Alarcơn GS, Schrohenloher RE, Bartlucci AA, Ward JR, Williams HJ, Koopman WJ. Suppression of rheumatoid factor production by methotrexate in patients with rheumatoid arthritis. Arthritis Rheum 1990; 33: 1156-1161. 
52. Segal R, Mozes E, Yaron M, Tartakovsky B. The effects of methotrexate on the production and activity of interleukin-1. Arthritis Rheum 1989; 32: 370-377.

53. Hirata S, Matsubara $T$, Saura $R$, Tatseishi $H$, Hirohata $K$. Inhibition of in vitro vascular endothelial cell proliferation and in vivo neovascularization by low-dose methotrexate. Arthritis Rheum 1989; 32: 1065-1073.

54. Boerbooms AMTh, Jeurissen MEC, van de Putte LBA. Methotrexate in refractory rheumatoid arthritis. Clin Rheumatol 1988; 7: 249-256.

55. Andersen PA, West SG, O'Dell JR, Via SS, Claypool RG, Kotzin BL. Weekly pulse methotrexate in rheumatoid arthritis. Clinical and immunological effects in a randomized double-blind study. Ann Intern Med 1985; 103: 489-496.

56. Lightfoot RW. Treatment of rheumatoid arthritis. In: Arthritis and allied conditions. A Textbook of Rheumatology. McArthy DJ. 11th ed. Lea \& Febiger, Philadelphia, London. Ch 47. 1989. 

Chapter 2

AZATHIOPRINE 



\subsection{CHEMISTRY, ABSORPTION, DISTRIBUTION, METABOLISM, EXCRETION}

Azathioprine (Imuran ${ }^{R}$ ) is a nitro-imidazole derivative of 6-mercaptopurine (6-MP) $(1 \mathrm{a}, 1 \mathrm{~b})$. Its structural formula is 6-(1 methyl-4-nitro 5-imidazolyl) thiopurine (Figure 1). Azathioprine (AZA) is well absorbed from the gastrointestinal tract. After oral administration, AZA rapidly disappears from the circulation and is extensively metabolized (see further). There is a relatively short elimination half-life ( $t^{1 / 2} / 2$ of $0.2-1$ hour (3). Within 24 hours about $50 \%$ of an oral dose AZA is excreted in the urine mainly as thiouric acid $(2,3)$. Small amounts $(10 \%)$ of unchanged AZA and 6-MP are eliminated in the urine. Approximately $12 \%$ of a dose is eliminated in the faeces. The plasma protein binding of AZA is about $30 \%$ (2). Its apparent volume of distribution (Vd) is 0.8 liter/kilogram (4).

In renal transplant patients with a mean creatinine clearance of $57 \mathrm{ml} / \mathrm{min}$ given 100 $150 \mathrm{mg} \mathrm{AZA}$ intravenously, the average $\mathrm{t}^{1 / 2}$ was $12.5 \pm 3.9$ minutes (5). In this study it was also demonstrated that a lower creatinine clearance [mean $13 \mathrm{ml} / \mathrm{min}$ (range 5-23)], did not influence the $t \frac{1}{2}$ of AZA. However, these authors point out that their results do not exclude the possibility that active AZA metabolites (i.c 6-MP ribonucleotides) may be responsible for the commonly observed intolerance to or toxicity of AZA in patients with poor renal function (5). Because of possibly reduced AZA clearance in patients with a glomerular filtration rate of less than $10 \mathrm{ml} / \mathrm{min}$, it is recommended to extend the dosage interval of AZA from 24 to 36 hours, or to reduce the dosage to $75 \%$ (3).

Pharmacokinetic data of 6-MP and AZA in RA patients are lacking. Since AZA and 6MP have to be converted to their ribonucleotides before exerting their pharmacologic action, determination of plasma levels of AZA and 6-MP is of no direct clinical value with respect to effectiveness or toxicity of AZA (6). When AZA crosses the placenta, much of the drug has been deactivated. Low foetal 6-MP levels, however, are detectable $(7,8)$.

The first step in metabolism of AZA is thiolysis by glutathione, a substance present in the liver and erythrocytes (9). The thiolysis leads to formation of gluthationyl imidazole and releases 6-MP. Thereafter methylation of the sulfhydryl group and oxidation of the

Figure 1. Structural formulas of azathioprine and 6-Mercaptopurine.

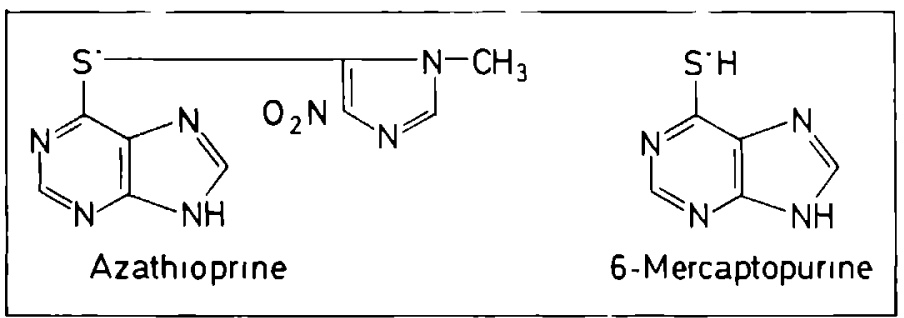


Figure 2. Metabolism of Azathioprine (AZA) and 6-Mercaptopurine (6-MP) and their influence on purine de-novo synthesis.

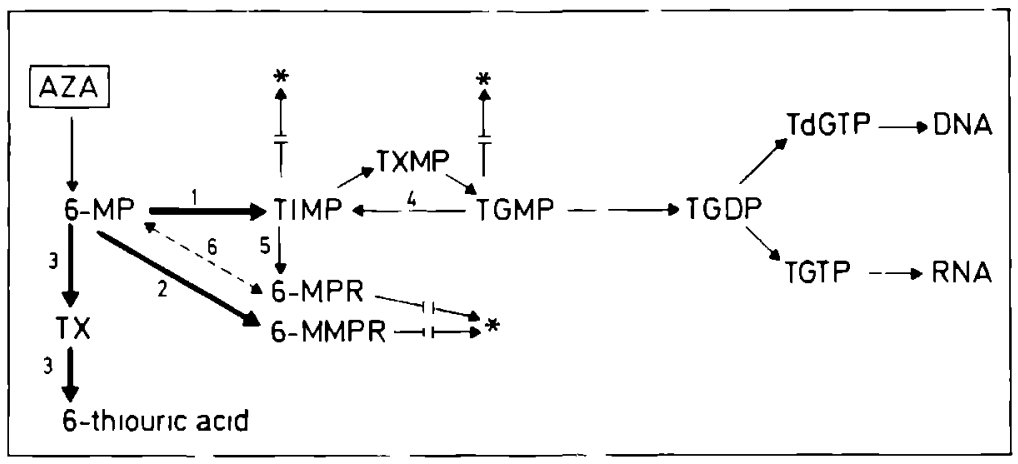

$1=$ Hypoxanthine guanine phosphoribosyltransferase (HGPRT)

$2=$ Thiopurine methyltransferase (TPMT)

$3=$ Xanthine oxydase

$4=$ GMP reductase

$5=$ Purine 5 nucleotidase (PNT)

$6=$ Purine nucleoside phosphorylase (PNP)

* = Inhibition of phosphoribosyl pyrophosphate (PRPP) amidotransferase and other enzymes of purine metabolism by 6-MP nucleotides (see also Figure 3 ).

methylated derivatives occur. The metabolism of 6-MP follows three major enzymatical routes $(10,11)$ (Fig 2), of which the first route is the most important one.

a. Conversion by the enzyme hypoxanthine guanine phosphoribosyl transferase (HGPRT), present in a.o erythrocytes. This conversion leads to thioinosinic monophosphate (TIMP), a known inhibitor of several enzymes in the purine de-novo synthesis such as inosinic monophosphate (IMP) dehydrogenase $(10,11,12)$. Finally via several enzymatic routes - incorporation into DNA and RNA synthesis occurs, which is a major mechanism of action of AZA (12). Drug resistance to AZA occurs in patients suffering from the Lesh Nyhan syndrome, an inborn error of metabolism due to deficiency of HGPRT $(13,14)$. Formation of TIMP requires phosphoribosyl pyrophosphate (PRPP) as a cofactor (10). Since methylthiopurines are inhibitors of PRPP amidotransferase and the natural nucleotides adenosine monophosphate (AMP) and guanine monophosphate (GMP) cause feedback inhibition of the same enzyme, the resultant decrease in AMP and GMP is called pseudo feedback inhibition (11) (Fig 3).

b. Oxidation by xanthine oxydase, an enzyme mainly present in the liver. Oxidation leads to formation of 6 thiouric acid, the major urinary metabolite of AZA. Other urinary metabolites are inorganic sulfate, nitromethyl thio-imidazole, 6 methylpurine derivatives and small quantities of 6-MP and $8 \mathrm{OH}-\mathrm{AZA}$. Concurrent use of allopurinol, a xanthine oxydase inhibitor, and AZA induces increased toxicity of AZA. In such a situation the dosage of AZA must be reduced by 75 percent $(11,15)$.

c. Formation of 6 methyl MP derivatives, catalyzed by thiopurine methyltransferase (TPMT). These metabolites also cause pseudo feedback inhibition (see above).

Inherited low TPMT activity with subsequent raised 6-thioguanine (TGN) levels is pro- 
Figure 3. Purine de-novo synthesis and inhibition by 6-Mercaptopurine nucleotides (= Pseudofeedback inhibition *).

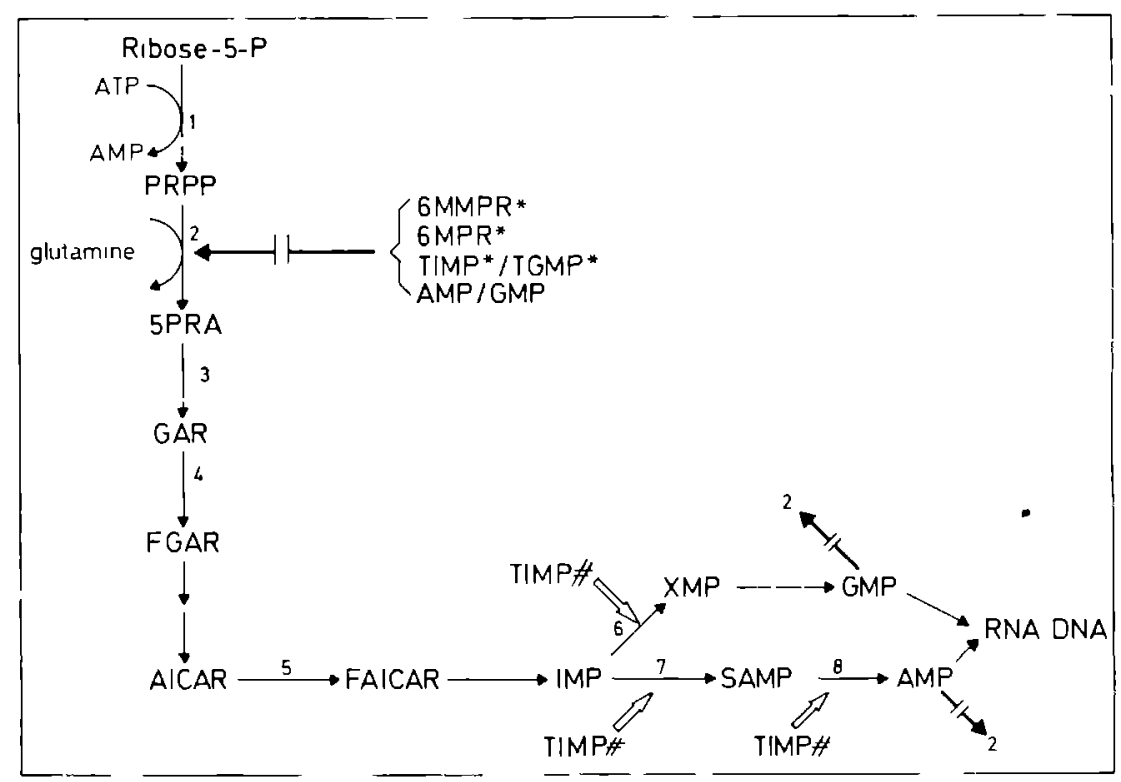

$1=$ Phosphonbosyltransferase synthetase

2 - Phosphonbosyl pyrophosphate (PRPP)amidotransferase

$3=$ Glycinamide nbonucleotide (GAR) synthetase

$4=$ GAR formyltransferase

$5=$ Amino imıdazolecarboxamide nbonucleotıde (AICAR) formyltransferase

$6=$ Inosinic monophosphate (IMP) dehydrogenase

7 - Adenylosuccinate synthetase

8 = Adenylosuccinate lyase

* = Since the natural nucleotides AMP and GMP cause feedback inhibition $(-\mapsto)$ of PRPP amidotransferase (2), the feedback by 6-MP nucleotides* is called pseudofeedback inhibition

\# = Thioınosinic monophosphate (TIMP) also inhibits the enzymes (6), (7), (8)

bably a major nsk for developing AZA induced myelosuppression $(12,16)$. 6-TGN is converted by HGPRT and leads to incorporation into DNA and RNA Very low TPMT activity occurs in 1 of 300 subjects and a low (=intermediate) activity in $11 \%$ of the population $(12,15)$

\subsection{MECHANISM OF DRUG RESISTANCE}

Drug resistance to AZA may occur due to HGPRT deficiency. It may also be caused by other mechanisms decreased drug transport, mutant form of HGPRT, loss of, or altered adenosine phosphonbosyl transferase (APRT) (11) and increase of alkalıne phosphatase activity in leucocytes $(11,17)$. Because only a minonty of leukemia patients with clinical 6-MP resistance showed low HGPRT activity $(10,18)$, other, yet unknown 
factors are probably involved in thiopurine resistance. A recent finding is that children with very high TPMT activity tolerate long periods of full doses of 6-MP. The authors suggested that conventional doses of 6-MP in these children represent undertreatment (19).

Hypothetically, a similar drug resistance to AZA in RA patients with very high TPMT activity may play a part in unresponsiveness to AZA. To our knowledge, thiopurine resistance in RA patients has not yet been investigated.

Some authors suggest that altered purine metabolism might play a part in the pathogenesis of RA. Therefore they measured some enzymes involved in purine metabolism (20). Of the three enzymes measured [purine-5-nucleotidase(PNT); purine nucleoside phosphorylase (PNP) and adenosine deaminase (ADA)], ADA and PNT had significantly lower levels than in a control group. The consequence of these findings is not yet clear.

\subsection{MECHANISM OF ACTION}

Both azathioprine (AZA) and 6-MP are purine analogues and pro drugs, that is, they must be converted to their ribonucleotides before they can exert cytotoxic activity $(16,10,11)$. Both drugs inhibit DNA and RNA synthesis early in the de-novo purine synthesis and at purine nucleotide interconversions (la,11).

The anti-inflammatory $(21,22)$ and immunosuppressive effects of thiopurines in animals, such as suppression of adjuvant arthritis, selective effect on T-cells in mice and decreased delayed type hypersensitivity in rabbits are well documented (22-24). However, extrapolation of these results to man is difficult in view of species variability and susceptibility to the drug.

Inhibition of the local inflammatory response by 6-MP in man, was shown by two authors $(25,26)$. Studying experimental inflammatory sites (skin window technique), 6MP inhibited the mononuclear cell exudation (25). In another study the polymorphonuclear cell function (chemotaxis, phagocytosis) did not change significantly in renal transplant recipients receiving AZA $(2.5 \mathrm{mg} / \mathrm{kg} / \mathrm{d})$ compared with a control group (27). A recent study in $30 \mathrm{RA}$ patients (28) demonstrated an inhibitory effect of AZA on the natural killer (NK) cell function, as also shown in renal transplant recipients (29). However, only the 4 hour, not the 24 hour NK cell function was suppressed (28). Since the role of NK cells in RA (immunoregulation?) is still unclear, the significance of this observation is unknown.

Studies focused on immunosuppressive properties of AZA in man have indicated conflicting results on the humoral immune response, possibly due to differences in nature and dose of test antigens used (29). The effect of AZA on the cellular immune response is weak and not convincing (29-32). No significant changes in CD4:CD8 ratio were found in RA patients treated with AZA $(2.5 \mathrm{mg} / \mathrm{kg} / \mathrm{d})(32)$. Finally, there are conflicting results about the effect of AZA on immunoglobulin synthesis and rheumatoid factor (3137).

In summary, data on immunosuppressive and anti-inflammatory effects of AZA in man are controversial. Despite established clinical effect in controlled clinical trials, the mechanism of action of AZA in RA remains unclear. 


\subsection{DRUG INTERACTIONS}

The increased toxicity following concurrent use of AZA and allopurinol, has been mentioned before. In renal allograft recipients the antifolate action of trimethoprim-sulfamethoxazole on the bone marrow did increase the myelosuppressive effect of AZA $(38,39)$. The inhibitory effect of AZA on non-depolarizing neuromuscular blocking drugs is probably caused by inhibition of the enzyme phosphodiesterase at the motor nerve terminal $(39,40)$. However, there is doubt about the clinical relevance of this interaction (40).

\subsection{DOSAGE OF AZA}

AZA is on the market in film coated tablets of $50 \mathrm{mg}$. Recently tablets containing 25 $\mathrm{mg}$ AZA became also available. The usual dosage for $\mathrm{RA}$ ranges from $1.5 \mathrm{mg} / \mathrm{kg}$ to maximally $2.5 \mathrm{mg} / \mathrm{kg}$ body weight, but dosages as low as $1 \mathrm{mg} / \mathrm{kg}$ can be effective (41). Vials containing $50 \mathrm{mg} \mathrm{AZA}$ are used for intravenous administration. Dose adjustment in patients with renal insufficiency was mentioned before. To avoid neonatal cytopenia it is recommended to halve the maternal dose of AZA during the third trimester of pregnancy (42).

\subsection{CONTROLLED CLINICAL TRIALS OF AZA (see also Tables 1 and 2)}

Double-blind trials of AZA compared with either placebo or other second-line drugs in some 800 RA patients have demonstrated the clinical efficacy of AZA. A significant steroid sparing effect of AZA was reported on in the first placebo controlled trial of AZA $(43,44)$. In other placebo controlled studies (AZA: $1.5-3.0 \mathrm{mg} / \mathrm{kg}$ ) significant improvement of articular indices and grip strength was present and manifest from the sixth week (45-47). After cross-over, relapse of $R A$ during placebo period developed (46). Full dose AZA $(2.5 \mathrm{mg} / \mathrm{kg}$ body weight daily) versus half dose $(1.25 \mathrm{mg} / \mathrm{kg}$ daily) was nearly equally effective (41), but in another study full dose was more effective (48). ESR remained unchanged in nearly all the trials of AZA mentioned. The number of withdrawals due to side effects ranged from 0 to $47 \%$. Radiologic results were too incomplete for interpretation.

Double-blind studies in which AZA was compared with other second-line drugs [cyclophosphamide $(49,50)$, parenteral gold $(49,52)$, chloroquine (52), D-penicillamine $(51,53,54)$, methotrexate $(34 a, 34 b)]$, did not reveal intergroup differences regarding clinical disease variables such as articular index, grip strength and morning stiffness. The rate of withdrawal due to side effects of AZA in these studies varied considerably (10$35 \%$ ). ESR fell in some studies, but remained unchanged in other studies. Radiologic results were the same on both drugs. However, radiologic data were often too limited for general conclusions regarding influence of these drugs on radiologic progression in RA. 
Table 1. Placebo controlled clinical trials of azathioprine in rheumatoid arthritis

\begin{tabular}{|c|c|c|c|c|}
\hline $\begin{array}{l}\text { Author } \\
\text { (ref) }\end{array}$ & $\begin{array}{l}\text { Number of } \\
\text { patients }\end{array}$ & $\begin{array}{l}\text { Follow-up } \\
\text { (wk) }\end{array}$ & $\begin{array}{l}\text { Dosage } \\
(\mathrm{mg} / \mathrm{kg} / \mathrm{d})\end{array}$ & Comments \\
\hline $\begin{array}{l}\text { Mason } \\
(43)\end{array}$ & 49 & 48 & 2.5 & $\begin{array}{l}\text { Signif. steroid sparing effect [all patients used steroids }(5-20 \mathrm{mg} / \\
\text { d)]; clinical data at } 48 \text { wk not mentioned; At } 120 \text { wk no benefit in } \\
30 \% \text { and withdr. due to side effects in } 30 \% \text { of patients. * }\end{array}$ \\
\hline $\begin{array}{l}\text { Levy } \\
(45)\end{array}$ & 18 & $2 \times 24$ & 3.0 & $\begin{array}{l}\text { Crossover at } 24 \text { wk; Marked or moderate clinical improv. in } 83 \% \text {; } \\
\text { Withdr. side effects in } 11 \% . \$\end{array}$ \\
\hline $\begin{array}{l}\text { Urowitz } \\
\text { (46) }\end{array}$ & 17 & $2 \times 16$ & $2-2.5$ & $\begin{array}{l}\text { Crossover at } 16 \text { wk; signif. improv. in } 4 \text { disease variables; Side } \\
\text { effects in } 23 \% \text { (no withdr.); ESR, Latex unchanged, signif. decr. } \\
\text { IgA } / \text { IgG; Radiographs ( } 10 \text { patients) no differences in placebo or } \\
\text { drug periods. } \$\end{array}$ \\
\hline $\begin{array}{l}\text { Urowitz } \\
(41)\end{array}$ & 31 & 24 & $\begin{array}{l}1-1.25 \\
\text { vs } 2-2.5 \#\end{array}$ & $\begin{array}{l}\text { Both drug groups signif. improv. in } 3 \text { disease variables; Withdr. } \\
\text { side effects in } 20 \% \text {; ESR, Latex unchanged, IgA signif. decrease. } \\
\text { In } 2 \text { patients radiographic progression after } 24 \text { wk. } \$\end{array}$ \\
\hline $\begin{array}{l}\text { Goebel } \\
(47)\end{array}$ & 30 & $2 \times 12$ & $1.5-2.0$ & $\begin{array}{l}\text { Signif. improv. in } 2 \text { disease variables; Side effects in 13\% (no } \\
\text { withdr.); signif. fall Iggs. \$ }\end{array}$ \\
\hline $\begin{array}{l}\text { Woodland } \\
(48)\end{array}$ & 42 & 24 & $\begin{array}{l}1.25 \\
\text { vs } 2.5 \\
\text { vs placebo }\end{array}$ & $\begin{array}{l}\text { Full dose more effective than half dose; signif. improv. } 3 \text { diseases } \\
\text { variables in full dose group; Withdr. side effects in } 47 \% \text { (full dose) } \\
\text { and } 29 \% \text { (half dose); ESR no signif. change. } \$\end{array}$ \\
\hline
\end{tabular}

* Long-term data from Harris et al. (44)

"No placebo group in this study

\$ Decr. = decrease; ESR = erythrocyte sedimentation rate; improv. = improvement; Iggs = immunoglobulins; Latex $=$ rheumatoid factor; signif. $=$ significant; withdr. $=$ withdrawal 
Table 2. Double-blind trials of azathioprine compared with other second-line drugs in rheumatoid arthritis

\begin{tabular}{|c|c|c|c|c|}
\hline $\begin{array}{l}\text { Author } \\
\text { (ref) }\end{array}$ & $\begin{array}{l}\text { Number of } \\
\text { patients }\end{array}$ & $\begin{array}{l}\text { Follow- } \\
\text { up (wk) }\end{array}$ & $\begin{array}{l}\text { Dosage } \\
\text { and drug }\end{array}$ & Comments \\
\hline $\begin{array}{l}\text { Currey } \\
(49)\end{array}$ & 121 & 72 & $\begin{array}{l}2.5 \mathrm{mg} / \mathrm{kg} / \mathrm{d} \\
\mathrm{AZA} \text { vs } 1.5 \\
\mathrm{mg} / \mathrm{kg} / \mathrm{d} \mathrm{CPA} \\
\text { vs } 50 \mathrm{mg} / \mathrm{wk} \text { AU }\end{array}$ & $\begin{array}{l}\text { No signif. intergroup differences except tender joint in CPA; CPA } \\
\text { and AZA steroid sparing effects; Withdr. side effects CPA (51\%), } \\
\text { AZA ( } 32 \%), \text { AU ( } 50 \%) \text {; More patients on AU marked radiologic } \\
\text { deterioration. } \$\end{array}$ \\
\hline $\begin{array}{l}\text { Levy } \\
(50)\end{array}$ & 42 & 24 & $\begin{array}{l}\text { CPA vs AZA } \\
\text { vs placebo } \\
\text { (unknown dosage) }\end{array}$ & $\begin{array}{l}\text { Crossover after } 24 \text { wk; AZA and CPA equally effective (signif. } \\
\text { decrease in } 3 \text { disease variables). } \$\end{array}$ \\
\hline $\begin{array}{l}\text { Berry } \\
(51)\end{array}$ & 65 & 48 & $\begin{array}{l}2.5 \mathrm{mg} / \mathrm{kg} / \mathrm{d} \\
\mathrm{AZA} \text { vs } 1000 \\
\mathrm{mg} / \mathrm{d} \text { D-P }\end{array}$ & $\begin{array}{l}\text { AZA and D-P equally effective; ESR signif. more decrease in } \\
\text { D-P; signif. fall Latex; Withdr. side effects AZA }(30 \%) \text {; D-P } \\
(30 \%) \text {; No radiologic differences. \$ }\end{array}$ \\
\hline $\begin{array}{l}\text { Dwosh } \\
\text { (52) }\end{array}$ & 33 & 24 & $\begin{array}{l}1-2 \mathrm{mg} / \mathrm{kg} / \mathrm{d} \\
\mathrm{AZA} \text { vs } 250 \\
\mathrm{mg} / \mathrm{d} \mathrm{ClQ} \\
\text { vs } 50 \mathrm{mg} / \mathrm{wk} \text { AU * }\end{array}$ & $\begin{array}{l}\text { No signif. differences in change of disease variables between the } \\
\text { drugs; Signif. fall ESR only in AU group; Withdr. side effects } \\
\text { AZA }(20 \%) \text {, C1Q }(10 \%) \text { and AU }(0 \%) \text {; No radiologic differen- } \\
\text { ces. \$ }\end{array}$ \\
\hline $\begin{array}{l}\text { Paulus } \\
\text { (53) }\end{array}$ & 206 & 24 & $\begin{array}{l}1.25-1.5 \mathrm{mg} / \mathrm{kg} / \mathrm{d} \\
\mathrm{AZA} \text { vs } 10-12 \\
\mathrm{mg} / \mathrm{kg} \mathrm{D}-\mathrm{P} *\end{array}$ & $\begin{array}{l}\text { Improv. nearly all (10) disease variables. No signif. intergroup } \\
\text { differences except for ESR and HB (in D-P more change); } \\
\text { Withdr. side effects AZA }(20 \%) \text {, D-P }(28 \%) \text { \$ }\end{array}$ \\
\hline
\end{tabular}

* Long-term data from Harris et al. (44)

\# No placebo group in this study

$\$$ Decr. = decrease; ESR = erythrocyte sedimentation rate; improv. = improvement; Iggs = immunoglobulins;

Latex $=$ rheumatoid factor; signif. $=$ significant; withdr. $=$ withdrawal 
Table 2. continued

\begin{tabular}{|c|c|c|c|c|}
\hline $\begin{array}{l}\text { Author } \\
\text { (ref) }\end{array}$ & $\begin{array}{l}\text { Number of } \\
\text { patients }\end{array}$ & $\begin{array}{l}\text { Follow- } \\
\text { up (wk) }\end{array}$ & $\begin{array}{l}\text { Dosage } \\
\text { and drug }\end{array}$ & Comments \\
\hline $\begin{array}{l}\text { Halberg } \\
\text { (54) }\end{array}$ & 74 & 96 & $\begin{array}{l}2.5 \mathrm{mg} / \mathrm{kg} / \mathrm{d} \\
\mathrm{AZA} \text { vs } 600 \\
\mathrm{mg} / \mathrm{d} \mathrm{D}-\mathrm{P} \\
\text { vs } 150 \mathrm{mg} / \mathrm{d} \text { Lev. * }\end{array}$ & $\begin{array}{l}\text { After } 8 \text { wk Lev. withdrawn due to agranulocytosis in } 4 \text { patients; } \\
\text { No signif. differences in change of disease variables between } \\
\text { AZA and D-P; Withdr. side effects AZA ( } 15 \%) \text {, D-P (11\%); } \\
\text { After } 96 \text { wk only } 1 / 3 \text { of the patients completed therapy (primary } \\
\text { treatment failure or relapse RA in } 48 \% \text { AZA and } 29 \% \text { D-P). No } \\
\text { signif. differences in radiologic results at } 96 \text { wk. } \$\end{array}$ \\
\hline $\begin{array}{l}\text { Hamdy } \\
(34 a)\end{array}$ & 42 & 52 & $\begin{array}{l}100-150 \mathrm{mg} / \mathrm{d} \\
\text { AZA vs } \\
10-15 \mathrm{mg} / \mathrm{wk} \\
\text { MTX }\end{array}$ & $\begin{array}{l}\text { Signif. decrease } 9 \text { disease variables in both groups. No intergroup } \\
\text { differences except for ESR (MTX signif. decrease ESR, Latex). } \\
\text { Trend toward more marked and rapid improv. in MTX; Withdr. } \\
\text { side effects AZA (10\%), MTX (10\%); No differences in radio- } \\
\text { logic results after } 24 \text { and } 52 \text { wk. \$ }\end{array}$ \\
\hline $\begin{array}{l}\text { Bell } \\
(34 b)\end{array}$ & 34 & 20 & $\begin{array}{l}100-150 \mathrm{mg} / \mathrm{d} \\
\mathrm{AZA} \text { vs } \\
10-15 \mathrm{mg} / \mathrm{wk} \\
\text { MTX }\end{array}$ & $\begin{array}{l}\text { Both drugs equally effective except more improv. grip strength in } \\
\text { MTX; Withdr. side effects AZA (35\%), MTX }(6 \%) \text {; Withdr. } \\
\text { other reasons in } 11 \% \text {. \$ }\end{array}$ \\
\hline
\end{tabular}

* $\quad \mathrm{AU}=$ parenteral gold; $\mathrm{AZA}=$ azathioprine; $\mathrm{ClQ}=$ chloroquine; $\mathrm{CPA}=$ cyclophosphamide; $\mathrm{D}-\mathrm{P}=\mathrm{D}$-penicillamine;

Lev = levamisole; MTX = methotrexate

$\$ \quad E S R=$ erythrocyte sedimentation rate; $\mathrm{HB}=$ hemoglobin; improv. = improvement; Latex = rheumatoid factor; signif. = significant; withdr. $=$ withdrawal 


\subsection{LONG-TERM EXPERIENCE}

In three retrospective long-term studies of AZA a sustained clinical improvement of about $40-50 \%$ was found after 2-3 years (55-57). Discontinuation due to adverse reactions occurred in about $20 \%$ of the patients and due to lack of effect in 14 to $44 \%$.

In a large scale retrospective study of 325 patients the probability of continuing the same second-line drug (a.o. AZA) after 3 years was only $10 \%$ (58). In a recent prospective study of 393 patients treated with AZA, discontinuation due to side effects (mainly gastrointestinal), occurred in $17.4 \%$ of the patients. Unfortunately the exact follow-up period and the number of patients withdrawn due to lack of effect were not mentioned (59).

In four prospective long-term studies of 21 (34a), 27 (44), 20 (54), and 17 (60) patients respectively, after follow-up periods of about 2 years, 30 to $50 \%$ of patients were still taking AZA. Discontinuation due to side effects occurred in 10 to $30 \%$ and due to lack of effect in 25 to $30 \%$ of patients. Radiologic evaluation disclosed progression in many patients. In one study radiologic as well as clinical results were similar for AZA and MTX (34a). However, the small number of patients at the end of that study, did not allow any conclusion about the ultimate influence of these drugs on radiologic progression in RA.

\subsection{ADVERSE REACTIONS}

The two most frequently encountered side effects of AZA are gastrointestinal complaints in about $20 \%$ and leucopenia in about $15 \%$ of patients $(14,61)$. The spectrum of adverse reactions is listed in Table 3.

Gastrointestinal complaints comprise nausea, vomiting and abdominal discomfort. Sometimes diarrhoea or mouth ulcers develop (61).

Hematological side effects such as leucopenia, pancytopenia (62), thrombocytopenia and pure red cell aplasia are mentioned in Chapter 9. A further case report of pancytopenia due to AZA was published as well (63). The hematological side effects induced by low TPMT activity were pointed out before.

Hepatotoxicity associated with AZA manifests itself with signs of cholestasis and hepatocellular damage. Underlying mechanisms are toxic, allergic or obstructive (64). There are several case reports of veno-occlusive disease and peliosis hepatis, due to nonthrombotic blockade of the venous outflow tract observed in recipients of renal transplants (65-67), systemic lupus erythematosus (68) and recently also in RA (69). The disorder is characterized clinically by hepatomegaly, ascites and variable liver enzyme elevations. Progressive liver failure with fatal outcome has been reported (70). The triad of severe liver function abnormalities, rash, and fever with chills is described in more detail in Chapter 9.

Pancreatitis attributed to AZA was found in several patients with Crohn's disease (71) and in one RA patient (72).

Azathioprine hypersensitivity has many manifestations ranging from fever (isolated or with rigors), to symptoms of a musculoskeletal (arthralgia, myalgia), cutaneous (urticaria, 
Table 3. Adverse Reactions to Azathioprine

\begin{tabular}{lll}
\hline Frequent $( \pm 15 \%)$ & Less frequent $(0-5 \%)$ & Rare $(<1 \%)$ \\
\hline gastrointestinal & $\begin{array}{l}\text { thrombocytopenia } \\
\text { leucopenia }\end{array}$ & hypersensitivity \\
mucosal ulcers & - fever \\
& & - arthralgia, \\
& myalgia \\
& - cholestasis \\
& - rash \\
& - shock \\
& - pancreatitis \\
& hematologic \\
& - pancytopenia \\
& - pure red cell aplasia \\
\hline
\end{tabular}

erythema nodosum-like), neurologic (headache, neuritis), cardiovascular (shock, hypotension), gastrointestinal (nausea, gastroenteritis, liverinjury, pancreatitis) or respiratory nature (pneumonitis) (73). Fever, diarrhoea, nausea, mimicking gastroenteritis, were found in some patients (74). There are numerous reports of life-threatening shock accompanied by other manifestations of hypersensitivity (75-79). Rechallenge with azathioprine in such cases is dangerous and should only be done under careful observation (77).

Azathioprine induced interstitial pneumonitis is another infrequent side effect. The clinical features comprise hypoxemia, low grade fever, abnormal chest radiographs and lung function tests (80-84). Histologically there is diffuse alveolar damage and in some patients interstitial fibrosis was found. Immune depositions in the lung were not demonstrated. Clinical improvement with normalization of radiographs mostly occurs within 2 weeks to 2 months. However, several patients died from superimposed infections (83). Whether the risk of infections in RA patients treated with AZA is increased, is debatable $(14,85)$. It is also a matter of debate whether AZA causes alopecia (85).

\subsection{FERTILITY, PREGNANCY, LACTATION}

In spite of exposure to immunosuppressive drugs, about $70 \%$ of 308 pregnancies of renal transplant recipients resulted in full-term infants (86). However, the possibility of neonatal immunosuppression and growth retardation of infants due to AZA cannot be excluded (87). The clinical relevance of the clastogenic effects of AZA on chromosomes of RA patients is unclear, since this abnormality disappeared on discontinuation of the drug $(88,89)$. Chromosomal abnormalities in 11 of 16 infants bom of transplant recipients returned to normal at 1 year of age (86).

The concentration of AZA in the breast milk (measured as 6-MP) is $1.2 \%$ of the maternal concentration (3). Since maximum infant plasma concentrations of 6-MP are less than $10 \%$ of maternal plasma concentrations, breast feeding of infants older than 34 
weeks is probably safe (3).

Studies of RA patients concerning male fertility during AZA therapy are scarce. In 23 patients with connective tissue diseases, AZA did not decrease sperm counts $(90,49)$. It is recommended to practice adequate contraception in women and men during the treatment period of AZA and for at least 3 months after the drug has been discontinued $(2,8)$.

\subsection{NEOPLASMS}

Much concem exists about a substantial excess of neoplasms (mainly non Hodgkin lymphoma and skin cancer) in renal transplant recipients who have received immunosuppressive drugs (85). However, in dialysis patients not receiving these drugs a similar increase of neoplasms was observed (91), so that the contribution of AZA to this increase remains unclear. A similar situation exists for RA patients. Although some authors did not find an excess of neoplasms in RA patients (92-94), there is much more evidence of an increased risk of lymphoproliferative malignancies in RA (95-100). The mean interval between the onset of RA and the diagnosis of neoplasms ranges from 11.8 to 17 years (95).

Hypotheses to explain the excess of neoplasms in auto-immune diseases are polyclonal B-cell proliferation - which triggers malignant transformation of cells - and activation of silent oncogenes by unknown antigen (96). An accelerated excess of neoplasms in RA patients treated with currently used AZA dosages (100-150 mg daily) has not been demonstrated at this moment $(101,102,55,59)$. In a study of $202 \mathrm{RA}$ patients treated with high dosage (300 mg AZA daily) and followed up for 20 years, an increased number of lymphomas (tenfold compared with fivefold in RA control group) was found (100). Further prospective studies with larger numbers of patients and longer follow-up periods ( $>10$ years) are necessary to elucidate the contribution of AZA to neoplasm induction in RA patients.

\section{REFERENCES}

1a. Elion GB, Callahan $S$, Bieber $S$, Hitchings $G H$, Rundles RW. A summary of investigations with 6-[(1 methyl-4-nitro-5 imidazolyl)thio]purine(BW57-322). Cancer Chemother Rep 1961; 14: 93-98.

1b. Elion GB. Biochemistry and pharmacology of purine analogues. Fed Proc 1967; 26: 899903.

2. Antineoplastic agents and Immunosuppressants. In: Martindale the extra Pharmacopoeia. Reynolds J.E.F. 26th edition. London, The Pharmaceutical Press, 1989.

3. Clinical Pharmacokinetics. Drug Data Handbook 1990. Mammen GJ, editor. 2nd edition. Auckland; ADIS Press Limited, 1990.

4. Bennett WM, Aronoff GR, Golper ThA, Morrison G et al. In: Drug prescribing in renal failure. Library of Congress-in-Publication data. American College of physicians. 1st ed, 1987.

5. Nan Lin S, Jessup V, Floyd M, Wang TsF, van Buren Ch T, Caprioli RM. Quantitation of plasma azathioprine and 6 mercaptopurine levels in renal transplant patients. Transplantation 1980; 29: 290-294.

6. Ding TL, Benet LZ. Determination of 6-mercaptopurine and azathioprine in plasma by 
high-performance liquid chromatography. J Chrom 1979; 163: 281-288.

7. Saarikoski S, Seppāāa M. Immunosuppression during pregnancy. Transmission of azathioprine and its metabolites from the mother to the fetus. Am J Obstetr Gynec 1973; 115: $1100-1106$.

8. Roubenoff R, Hoyt J, Petri M, Hochberg MC. Effects of inflammatory and immunosuppressive drugs on pregnancy and infertility. Semin Arthritis Rheum 1988; 18: 88-110.

9. Menard DB, Gisselbrecht Ch, Marty M, Reyes F, Dhumeaux D. Antineoplastic agents and the liver. Gastroenterology 1980; 78: 142-164.

10. Zimm S, Johnson GE, Chabner BA, Poplack DG. Cellular pharmacokinetics of mercaptopurine in human neoplastic cells and cell lines. Cancer Research 1985; 45: 4156-4161.

11. Calabresi P, Parks RE. Antiproliferative agents and drugs used for immunosuppression. In: Goodman and Gilman's. The pharmacological basis of therapeutics. MacMillan Publishing Company. New York, London, Toronto. Ch 55; 7th ed, 1985.

12. Lennard L, van Loon JA, Weinshilboum RM. Pharmacogenetics of acute azathioprine toxicity. Relationship to thiopurine methyltransferase genetic polymorphism. Clin Pharmacol Ther 1989; 46: 149-154.

13. Nyhan WL, Sweetinan L, Carpenter DG, Carter CH, Hoefnagel D. Effects of azathioprine in a disorder of uric acid metabolism and cerebral function. J Pediatric 1968; 72 : 111-118.

14. Bunch ThW, O'Duffy JD. Disease modifying drugs for progressive rheumatoid arthritis. Mayo Clin Proc 1980; 55: 161-179.

15. Decker JL, Steinberg AD. Immune regulatory Drugs. In: Arthritis and allied conditions. McArthy DJ. Lea \& Febiger, Philadelphia. Ch 33, 10th ed, 1985.

16. Lennard L, Lilleyman JS. Are children with lymphoblastic leukaemia given enough 6mercaptopurine? Lancet 1987; ii: 785-787.

17. Rosman M, Lee MH, Creasey W, Sartorelli AC. Mechanism of resistance to 6-thiopurines in human leukemia. Cancer Research 1974; 34: 1952-56

18. Zimm S, Reaman G, Murphy R, Poplack DG. Mercaptopurine resistance in patients with acute lymphoblastic leukemia. Proc Am Soc Clin Oncol 1985; 5: 34.

19. Lennard L, Lilleyman JS, van Loon J, Weinshilboum RM. Genetic variation in response to 6-mercaptopurine for childhood acute lymphoblastic leukaemia. Lancet 1990; 336: 225229.

20. Appelboom Th, Mandelbaum I, Vertongen F. Purine enzyme levels in rheumatoid arthritis. J Rheum 1985; 12: 1075-1078.

21. Stevens JE, Willoughby DA. The anti-inflammatory effect of some immunosuppressive agents. J Pathol 1969; 97: 367-373.

22. Hurd ER. Immune suppressive and anti-inflammatory properties of cyclophosphamide, azathioprine and methotrexate. Arthritis Rheum 1973; 16: 84-88.

23. Currey HLF. A comparison of immunosuppressive and anti-inflammatory agents in the rat. Clin Exp Immunol 1971; 9: 879-887.

24. Levy L. Effects of predosing animals with immunosuppressive drugs on immune and nonimmune induced inflammatory responses. Arch Intern Pharmacodyn 1974; 211: 8-17.

25. Hersh ER, Wong VG, Freireich EJ. Inhibition of the local inflammatory response in man by antimetabolites. Blood 1966; 27: 38-48.

26. Page AR, Condie RM, Good RA. Suppression of plasma cell hepatitis with 6-mercaptopurine. Am J Med 1964; 36: 200-213.

27. Losito A, Williams DG, Cooke G, Harris L. The effects on polymorphonuclear leucocyte function of prednisolone and azathioprine in vivo and prednisolone, azathioprine and 6mercaptopurine in vivo. Clin Exp Immunol 1978; 32: 423-428.

28. Cseuz R, Panayi GS. The inhibition of NK cell function by azathioprine during the treatment of patients with rheumatoid arthritis. Br J Rheumatol 1990; $29: 358-362$.

29. Ten Berge RJM, Schellekens PTh. A critical analysis of the use of azathioprine in clinical medicine. Neth J Med 1983; 26: 167-171.

30. Denman EJ, Denman AM, Greenwood BM, Gall D. Failure of cytotoxic drugs to suppress immune responses of patients with rheumatoid arthritis. Ann Rheum Dis 1970; 29: $220-231$.

31. Urowitz MB, Gordon DA, Smythe HA, Pruzonski $\mathbf{N}$ et al. Azathioprine in rheumatoid arthritis. A double-blind crossover study. Arthritis Rheum 1973; 16: 411-418. 
32 Fōrre O, Bjerkhoel F, Salvesen Ch F, Berg KJ An open controlled randomized comparison of cyclosporin and azathioprine in the treatment of rheumatoid arthritis Arthritis Rheum 1987, 30 88-92

33 Levy J, Barnett EV, MacDonald NS, Klinenberg JR, Pearson CM The effect of azathioprine on gammaglobulin synthesis in man J Clin Invest 1972, 51 2233-2238

34a Handy H, McKendry RJR, Mierins E, Liver JA Low-dose methotrexate compared with azathioprine in the treatment of rheumatoid arthritis $A$ twenty-four weeks controlled clinical trial Arthritıs Rheum 1987, 30 361-367

34b Bell M, Change CH, Keystone EC, Urowitz MB, Gladmann D, Ching CF A doubleblind, randomized, controlled trial of azathioprine and methotrexate in the treatment of rheumatoid arthritis Arthritis Rheum 1988, 31 D72 (Abstr)

35 Dwosh IL, Stein HB, Urowitz MB, Smythe HA et al Azathioprine in early rheumatoid drthritis Comparison with gold and chloroquine Arthritis Rheum 1977, 20 685-692

36 Berry H, Liyanage SP, Durance RA, Barnes CG, Berger LA et al Azathioprine and penicillamine in the treatment of rheumatoid arthritis A controlled trial Br Med J 1976, 1 1052-1054

37 Jeurissen MEC, Boerbooms AMTh, van de Putte LBA, Doesburg W, Mulder J et al Superiority of methotrexate to azathioprine in advanced rheumatoid arthritis Results of a randomized double-blınd trial Arthritis Rheum 1990, 33 S39 (Abstract)

38 Bradley PP, Warden GD, Maxwell JG, Rothoteen G Neutropenia and thrombocytopenıa in renal allograft recipients treated with trimethoprim-sulfamethoxazole Ann Intern Med $1988,93560-563$

39 Griffin JP, D'Arcy PF, Spurs CJ In A manual of adverse drug interactions Wright London, Boston, Toronto, 4th ed, 1988

40 Smith NT, Corbaseio AN In Drug interactions in anesthesia Lea \& Febiger, Philadelphia, 2nd ed, 1986, 364-365

41 Urowitz MB, Hunter T, Bockman AAM Azathıoprine in rheumatoid arthritıs A doubleblınd study comparing full dose to half dose J Rheumatol 1974, 1 274-281

42 Briggs GG, Freeman RK, Ydffe SJ In Drugs in pregnancy and lactation A reference guide to fetal and neonatal risk Williams \& Wilkıns Baltımore, London 1986, 2nd ed, $35^{\prime}-36^{\circ}$

43 Mason M, Currey HLF, Barnes CG, Dunne JF, Hazleman BL, Strickland ID Azathioprine in rheumatoid arthritis Br Med J 1969, 1 420-422

44 Harris J, Jessop JD, Chdput de Saintonge DM Further experience with azathioprine in rheumatoid arthritis Br Med J 1971, 4 463-464

45 Levy J, Paulus HE, Barnett EV, Sokoloff M, Bongert R, Pearson CM A double controlled evaluation of azathioprine treatment in rheumatoid arthritis and psoriatic drthrit1s Arthritis Rheum 1972, 15 116-117

46 Urowitz MB, Gordon DA, Smythe AA, Pruranskı W, Ogryzlo MA Azathıprine in rheumatoid arthritis a double-blınd cross-over study Arthritis Rheum 1973, 16 411-418

47 Goebel KM, Janzen R, Jeseph K, Borngen U Disparity between clinical and immune responses in a controlled trial of azathioprine in rheumatoid arthritis Eur J Clin 1976, 9 $405-410$

48 Woodland J, Chaput de Saintonge DM, Evans SJW, Sharman VL, Currey HLF Azathioprine in theumatoid arthritis double-blind study of full versus half doses versus placebo Ann Rheum Dis 1981, $40355-59$

49 Currey HLF, Harris J, Mason RM, Woodland J, Beverıdge T, Roberts CJ, Vere DW, Dixon AS et al Comparison of azathioprine, cyclophosphamide and gold in treatment of rheumatoid arthritis Br Med J 1974, 3 763-766

50 Levy J, Paulus HE, Bongert R Comparıson of azathıprine (AZ) and cyclophosphamide (CPA) in the treatment of rheumatoid arthritıs (RA) Arthritıs Rheum 1975, 18 412-413

51 Berry H, Liyanage SP. Durance RA, Barnes CG, Berger LA, Evans S Azathioprine and penicillamine in treatment of rheumatord arthritıs A controlled trial $\mathrm{Br}$ Med J 1976, I $1052-1054$

52 Dwosh IL, Stein HB, Urowitz MB, Smythe HA, Hunter T, Ogryzlo MA Azathıprıne in early rheumatoid arthritis Comparison with gold and chloroquine Arthritıs Rheum 1977, $20 \quad 685-692$

53 Paulus HE, Williams HJ, Ward JR, Reading JC, Eggen MJ, Coleman ML, Samuelson $\mathrm{CO}$, Willkens RF et al Azathioprine versus D-penicillamine in rheumatoid arthritıs patients who have been treated unsuccessfully with gold Arthritıs Rheum 1984, 27 721727 
54. Halberg P, Bentzon MW, Crohn O, Gad I et al. Double-blind trial of levamisole, penicillamine, azathioprine in rheumatoid arthritis. Dan Med Bull 1984; 31: 403-409.

55. Speerstra F, Boerbooms AMTh, van de Putte LBA, van Beusekom HJ, Kruijsen MWM, Vandenbroucke JP. Side effects of azathioprine treatment in theumatoid arthritis: analysis of 10 years of experience. Ann Rheum Dis 1982; (Suppl) 41: 37-39.

56. Pinals RS. Azathioprine in the treatment of chronic polyarthritis: long-term results and adverse effects in 25 patients. J Rheum 1976; 3: 140-144.

57. Van Wanghe $P$, Dequeker J. Compliance and long-term effects of azathioprine in 65 rheumatoid arthritis cases. Ann Rheum Dis 1982; (Suppl) 41: 40-43.

58. Thompson PW, Kirwan JR, Barnes CG. Practical results of treatment with disease modifying antirheumatoid drugs. Br J Rheum 1985; 24: 167-175.

59. Singh G, Fries JF, Spitz P, Williams CA. Toxic effects of azathioprine in rheumatoid arthritis. A national post-marketing perspective. Arthritis Rheum 1989; 32: 837-843.

60. Hunter Th, Urowitz MB, Gordon DA, Smythe HA, Ogryzes MA. Azathioprine in rheumatoid arthritis. A long-term follow-up study. Arthritis Rheum 1975; 18: 15-20.

61. Whisnant JK, Pelkey J. Rheumatoid arthritis: treatment with azathioprine (Imuran ${ }^{R}$ ). Clinical side effects and laboratory abnormalities. Ann Rheum Dis 1982; 41: 44-47.

62. Jeurissen MEC, Boerbooms AMTh, van de Putte LBA. Pancytopenia related to azathioprine in rheumatoid arthritis. Ann Rheum Dis 1988; 47: 503-505.

63. Verhelst JA, van den Enden E, Mathijs R. Rapidly evolving azathioprine induced pancytopenia. J Rheum 1987; 14: 862.

64. Jeurissen MEC, Boerbooms AMTh, van de Putte LBA, Kruijsen MWM. Azathioprine induced fever, chills, rash and hepatotoxicity in rheumatoid arthritis. Ann Rheum Dis 1990; 49: 25-27.

65. Degott C, Ruiff B, Kreis $\mathbf{H}$, Duboust A et al. Peliosis hepatis in recipients of renal transplants. Gut 1978; 19: 748-753.

66. Katzka DA, Saul SH, Jorkasky D, Sigal $H$ et al. Azathioprine and hepatic veno-occlusive disease in renal transplant patients. Gastroenterology 1986; 90: 446-454.

67. Read AE, Russel H, Wiesner H, Douglas R, Labrecque $R$ et al. Hepatic veno-occlusive disease with renal transplantation and azathioprine therapy. Ann Int Med 1986; 104: 651655.

68. Pappas Sch, Malone DG, Rabin L, Hoofnagle JH, Jones EA. Hepatic veno-occlusive disease in a patient with systemic lupus erythematosus. Arthritis Rheum 1984; 27: 104108.

69. Lemley DE, Delacy LM, Seeff LB, Ishak KG, Nashel DJ. Azathioprine induced hepatic veno-occlusive disease in rheumatoid arthritis. Ann Rheum Dis 1989; 48: 342-346.

70. Zarday Z, Veith FJ, Gliedman ML, Sobermann R. Irreversible liver damage after azathioprine. JAMA 1972; 222: 690-92.

71. Sturdevant RAL, Singleton JW, Deren JL, Law DH et al. Azathioprine-related pancreatitis in patients with Crohn's disease. Gastroenterology 1979; 77: 883-886.

72. Pozniak AL, Ahern M, Blake DR. Azathioprine induced shock. Br Med J 1981; 283: 1548.

73. Saway PA, Heck LW, Bonner JR, Kirklen JK. Azathioprine hypersensitivity. Case report and review of the literature. Am J Med 1988; 84: 960-964.

74. Assini JF, Hamilton R, Strosberg JM. Adverse reactions to azathioprine mimicking gastroenteritis. J Rheum 1986; 13: 1117-1118.

75. Keystone EC, Schabas R. Hypotension with oliguria: a side effect of azathioprine. Arthritis Rheum 1981; 24: 1453-54.

76. Cunningham T, Barraclough D, Muirden K. Azathioprine-induced shock. Br Med J 1981; 283: 923-824.

77. Rosenthal E. Azathioprine shock. Postgrad Med J 1986; 62: 677-678.

78. Major GAC, Moore PG. Profound circulatory collapse due to azathioprine. JR Soc Med 1985; 78: 1052-1053.

79. Zaltzman M, Kallenbach J, Shapiro T, Lewis $M$. Life-threatening hypotension associated with azathioprine therapy. South Afric med J 1984; 65: 306.

80. Weisenburger DD. Interstitial pneumonitis associated with azathioprine therapy. Am J Clin Path 1978; 69: 181-185.

81. Rubin G, Baume P, Vandenberg R. Azathioprine and acute restrictive lung disease. Austr NZJ Med 1972; 3: 272-274.

82. Krowka MJ, Breuer RI, Kehoe ThJ. Azathioprine associated pulmonary dysfunction. Chest 1983; 4: 696-98. 
83. Bedrossian CW, Sussman J, Conklin RH, Kahan B. Azathioprine-associated interstitial pneumonitis. Am J Clin Path 1984; 82: 148-154.

84. Carmichael DJS, Hamilton DV, Evans DB, Stovin PGI, Caene RY. Interstitial pneumonitis secondary to azathioprine. Thorax 1983; 38: 951-952.

85. Lawson DH, Lovatt GE, Gurton CS, Hennings RC. Adverse effects of azathioprine. Adv Drug React Ac Pois Rev 1984; 3: 161-171.

86. Rudolph JE, Schweitzer RT. Pregnancy in renal transplant patients. Transplantation 1979; 27: 26-29.

87. Roubenoff R, Hoyt J, Petri M, Hochberg MC, Hillman DB. Effects of anti-inflammatory and immunosuppressive drugs on pregnancy and infertility. Semin Arthritis Rheum 1988; 18: 88-110.

88. Hunter Th, Urowitz MB, Gordon DA, Smythe HA, Ogryzlo MA. Azathioprine in rheumatoid arthritis. A long-term follow-up study. Arthritis Rheum 1975; 18: 15-20.

89. Jensen MJ. Effect of azathioprine on the chromosome complement of the human bone marrow cells. Int J Cancer 1970; 5: 147-151.

90. Mason M, Brown JA, Harris J, Woodland J. Treatment of systemic lupus erythematosus. Br Med J 1973; 2: 422.

91. Kinlen LJ, Eastwood JB, Kerr DN. Cancer in patients receiving dialysis. Br Med J 1980; 280: $1401-03$.

92. Miller DG. The association of immune diseases and malignant lymphoma. Ann Intern Med 1967; 66: 507-521.

93. Oleinick A. Leukemia or lymphoma occurring subsequent to an autoimmune disease. Blood 1967; 29: 144-153.

94. Lewis RB, Castor RW, Kinsley RE. Frequency of neoplasia in systemic lupus erythematosus and rheumatoid arthritis. Arthritis Rheum 1976; 19: 1256-1260.

95. Symmons DP. Neoplasia in rheumatoid arthritis. J Rheumatol 1988; 15: 1319-1322.

96. Scla O, Schonfeld J. Cancer in auto-immune diseases. Semin Arthritis Rheum 1988; 18: 77-87.

97. Isomaki HA, Hakulinen T, Jontsenlahte V. Excess risk of lymphoma, leukemia and myeloma in patients with rheumatoid arthritis. J Chron Dis 1978; 31: 691-696.

98. Hakulinen $T$, Isomaki $H$, Knekt $P$. Rheumatoid arthritis and cancer studies based on linking nationwide registries in Finland. Am J Med 1985; 78: 29-32.

99. Laakso M, Mutro O, Isomaki H. Cancer Mortality in patients with rheumatoid arthritis. J Rheum 1986; 13: 522-526.

100. Silman AJ, Petric J, Hazleman B, Evans SJW. Lymphoproliferative cancer and other malignancy in patients treated with azathioprine: a 20 year follow-up study. Ann Rheum Dis 1988; 47: 988-992.

101. Hazleman B. Incidence of neoplasia in patients with rheumatoid arthritis exposed to different treatment regimens. Am J Med 1985; (Suppl) 78: 39-43.

102. Kirsner AB, Farber SJ, Sheon RP, Funkel RI. The incidence of malignant disease in patients receiving cytotoxic therapy for rheumatoid arthritis. Ann Rheum Dis 1982; (Suppl) 41: 32-33. 

Chapter 3

METHOTREXATE 



\subsection{CHEMISTRY, TRANSPORT, POLYGLUTAMATION}

The structural formula of methotrexate (MTX) is 4-amino-4 deoxy-N10-methylpteroylglutamic acid (Figure 1). This formula resembles that of folic acid $(1,2)$

MTX is transported via an active camer-mediated system into the hepatic cells $(1,2)$ The drug is manly converted to MTX Polyglutamates (P-Glu), catalyzed by folylglutamate synthetase (Figure 2) Polyglutamation is an important process leading to intracellular retention and accumulation of MTX, mainly in the liver and to a less extent in erythrocytes The enzyme dihydrofolate reductase (DHFR), however, is the target of action of MTX (see mechanism of action). Polyglutamate chan length increases with higher concentrations of MTX and longer duration of exposure to MTX (1) Low-dose MTX therapy in RA does not cause progressive accumulation of MTX-P-Glu in either the liver or the erythrocytes, not even after several years of therapy $(3,4,5)$. Depleted (decrease of about $80 \%$ ) hepatic folate levels were found in RA patients treated with lowdose MTX (3)

\subsection{ABSORPTION, DISTRIBUTION, METABOLISM, EXCRETION}

Several studies have indicated that MTX absorption was rapid and complete after dosages of less than $30 \mathrm{mg} / \mathrm{m}^{2}(1,2)$ Other, recent studies have demonstrated that the extent of absorption may be well under $50 \%$ for doses of $10-15 \mathrm{mg} / \mathrm{m}^{2}$ MTX (6) Food (cspecially dairy products), intestınal bactena and non-absorbable antibıtics can influence

Figure 1. Structural formulas of methotrexate, folic acid and leucovorin.

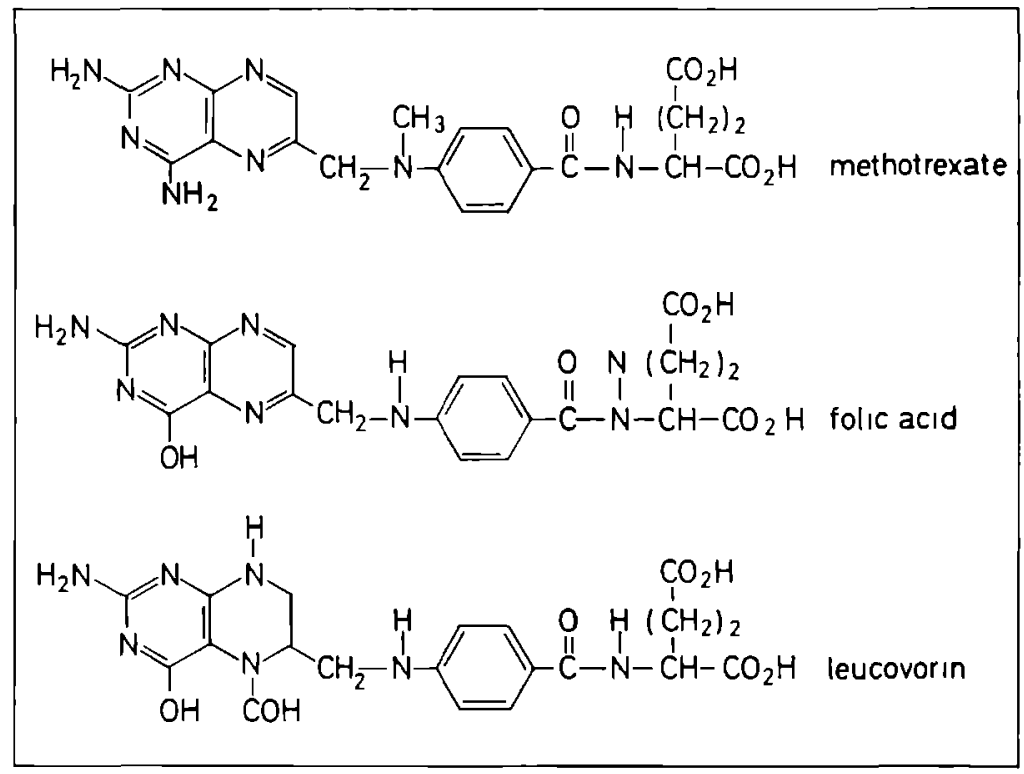


Figure 2. Influence of methotrexate (MTX) and its metabolites (MTX) polyglutamates) on purine de-novo (RNA/DNA) and pyrimidine (DNA) synthesis.

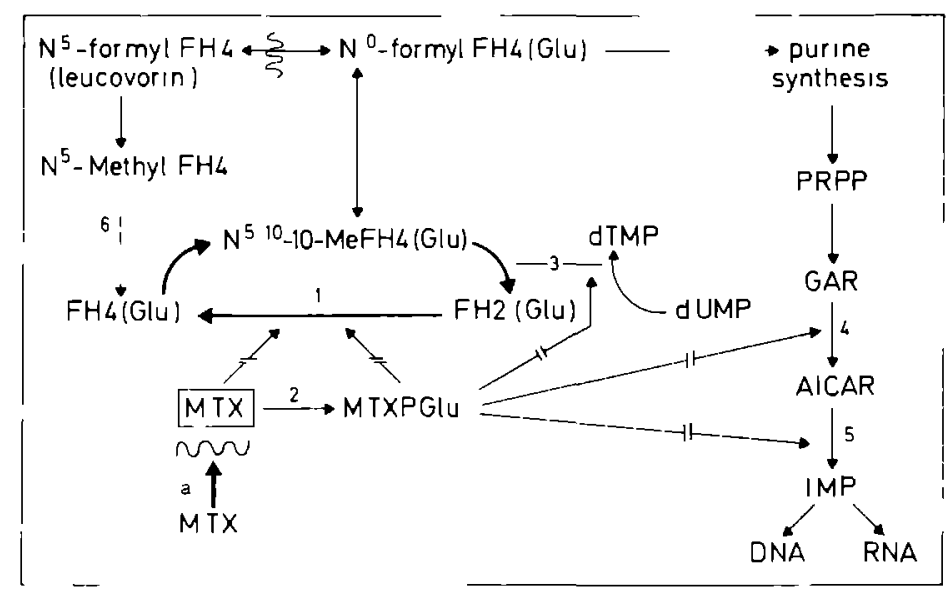

$\begin{array}{lll}\text { a } & =\text { Active transport of MTX across cell membrane } \\ 1 & =\text { Dihydrofolatereductase (DIIFR) most important target enzyme of MTX action } \\ 2 & =\text { Folylglutamatesynthetase } \\ 3 & =\text { Thymidinesynthetase } \\ 4 & =\text { GAR formyltransferase } \\ 5 & =\text { AICAR formyltransferase } \\ 6 & =\text { Methionine synthetase } \\ \text { MTXPGlu } & =\text { Methotrexate polyglutamates } \\ \text { MeFH4 } & =\text { Methylene tetrahydrofolate } \\ \text { FH2 } & =\text { Dihydrofolate }\end{array}$

Other abbreviations are mentioned in the list of Abbreviations

the absorption of MTX $(6,7,8)$. Alteration in plasma protein binding affects the amount of free extracellular MTX, which can result in increased toxicity. Fifty to seventy percent of MTX is bound to proteın, mainly albumin.

The mean bioavarlability (1.e. degree of absorption of a drug into the general circulation) for commercial MTX tablets ranges from 25-100\% (mean 73\%) (9) The volume of distnbution (Vd) of MTX is about $1 \mathrm{~L} / \mathrm{kg}$. The Vd of 7-OH MTX is much smaller (10). $\mathrm{High}$ values of $\mathrm{Vd}(>1 \mathrm{~L} / \mathrm{kg})$ mean high tissue concentrations compared with plasma and vice versa

Distribution. Recent pharmacokınetic studies of low-dose MTX $(7.5-15 \mathrm{mg} / \mathrm{wk})$ therapy in RA and psonasis patients have demonstrated a biphasic disappearance of MTX $(5,6,9,11)$. The mean initial (distnbution) half-life $(t 1 / 2)$ was found to range between 01 and 12 hour, the mean terminal (elimination) t $1 / 2$ between 45 and 65 hours $(5,6,11)$. In one study ( 9 ) different mean initial and terminal t $1 / 2$ values (3.3 and 149 hours respectively) were found. Perhaps decreased renal function in several patients in this study may explain the different results compared with the three other studies 
Distribution and accumulation of MTX in tissues and organs depend on factors such as blood flow to the organs, permeation of MTX into tissues, the amount of intracellular PGlu and the level of DHFR (2). Proximal tubules of kidney, liver and intestinal epithelium preferentially contain MTX $(7,12)$.

The recovery of DNA synthesis of duodenal cells in mice was found to occur only when plasma MTX concentrations were $1 \times 10^{-8} \mathrm{M}$ or less (13). In view of this observation, a safe, critical 24 hour MTX plasma level of about $10^{8} \mathrm{~mol} / 1$ in RA patients has been recommended (14). In several pharmacokinetic studies of RA and psoriasis patients treated with low-dose MTX (7.5-15 mg/wk), 24 hour MTX levels of less than $4 \times 10^{-8}$ $\mathrm{mol} / 1$ were found $(3,6,9,11)$. The critical MTX level recommended for patients with malignancies is much higher $(15 a, 15 b)$.

In the presence of pleural or peritoneal effusions, MTX may be trapped in these socalled 'third spaces'. These spaces may act as reservoirs and may result in prolonged plasma disappearance of MTX, which can lead to increase of toxicity $(1,2)$. Entry of MTX across the blood-brain barrier occurs slowly and is limited. With doses of 5-100 $\mathrm{mg} / \mathrm{m}^{2} \mathrm{MTX}$, the cerebrospinal fluid MTX levels are about $1 \%$ of the plasma concentration (2). MTX synovial fluid levels obtained from RA patients were similar (5) or higher (16) than MTX serum levels. Ratios of MTX in synovial fluid: MTX in serum of 0.9-1.2 (5) to 1.6-7.0 (16) were found.

Metabolism. At low doses of MTX there is relatively little metabolism (2). However with increasing doses (mainly high-dose MTX), 7-OH MTX, the major metabolite of MTX, becomes more important. The 7-OH compound is formed by aldehyde oxidase in the liver. Like MTX, 7-OH MTX is polyglutamated (2). Due to its high protein binding (91-93\%), it is suggested that 7-OH MTX is, at least in part, involved in drug interaction between (high-dose) MTX and nonsteroidal anti-inflammatory drugs (NSAIDs) (10). In low-dose MTX used in rheumatic diseases, the $7-\mathrm{OH}$ compound is probably not clinically important (17a).

Excretion. Renal excretion is the major $(80-90 \%)$ route of MTX elimination $(1,2)$. At low plasma MTX concentrations, there is renal reabsorption. At higher concentrations the clearance of MTX exceeds that of inulin, indicating active tubular secretion as well as glomerular filtration $(1,2)$

Methotrexate kinetics were studied in 14 RA patients treated with $15 \mathrm{mg}$ MTX weekly. Mean kinetic variables did not differ significantly when patients were treated with or without NSAIDs. However in three patients with decreased renal clearance $(<50$ $\mathrm{ml} / \mathrm{min}$ ), elimination half-life and area under serum concentration versus time curve (AUC) of MTX increased markedly. This urges caution in prescribing MTX therapy in RA patients with diminished $(<50 \mathrm{ml} / \mathrm{min})$ renal function (9). The biliary secretion of MTX is less important than the renal excretion. Most of the MTX, excreted in the bile, is reabsorbed (enterohepatic circulation). Only a small percentage (1-2\%) is found in the stools as unchanged drug. The biliary elimination is increased in impaired renal function $(8,17 \mathrm{~b})$. 


\subsection{MECHANISM OF ACTION (see also Chapter 1 and 4)}

MTX, 7-OH-MTX, and MTX-P-Glu are inhibitors of folate dependent enzymes such as dihydrofolate reductase (DHFR), thymidine synthetase (TS), 5 aminoimidazole-4-carboxamide ribonucleotide (AICAR) transformylase and glycinamide ribonucleotide (GAR) transformylase. All these folate dependent enzymes are involved in the pyrimidine (DNA) synthesis and the de-novo purine synthesis of DNA and RNA $(1,2,18)$ (Figure 2). Of these enzymes, dihydrofolate reductase (DHFR) is the major one. The 7-OH MTX compound is a less active inhibitor of DHFR than MTX itself (18). Inhibition of DHFR leads to depletion of tetrahydrofolates (FH4). FH4s are essential for DNA, RNA and protein synthesis.

\subsection{DRUG INTERACTIONS}

In addition to the data mentioned in Chapter 4, the combination of MTX with other antifolate drugs such as trimethoprim and trimethoprim-sulfamethoxazole (=cotrimoxazole), can increase myelosuppression or folate deficiency in some patients $(19,20)$.

\subsection{DOSAGE OF MTX}

In Chapter 4 the dosage of MTX used in RA and other connective tissue diseases is discussed. In 1988 low-dose MTX (7.5-15 mg/wk) was approved by the Food and Drug Administration (FDA) for the treatment of RA (21). Unlike the situation in psoriasis (22), there appears to be little scientific rationale for use of the divided dosage regimen of three fractional dosages of $2.5 \mathrm{mg}$ MTX every 12 hours in RA (23). The psoriatic epidermal cell has a rapid rate of proliferation: duration of psoriatic cell cycle 37.5 hours (hr) compared with $457 \mathrm{hr}$ for the normal epidermal cell (22). Within the period of $36 \mathrm{hr}$ almost all psoriatic cells would theoretically enter the MTX-susceptible S-phase [i.e DNA synthesis period $(16 \mathrm{hr})]$ of the cell cycle (22).

\subsection{LEUCOVORIN}

Leucovorin, the formyl derivative of folinic acid (Figure 2), is used as a 'rescue technique' to reduce MTX toxicity. The substance decreases the entry of MTX into the cells and repletes the intracellular pool of FH4. From uncontrolled and several placebo controlled studies, there are conflicting results about the influence of leucovorin on toxicity and efficacy of MTX. In two studies there was decrease in toxicity (e.g stomatitis) with unchanged efficacy $(24,25)$ of MTX. In two other studies $(26,27)$ there was no effect at all, whereas in one study there was decrease of MTX toxicity but worsening of RA activity (28). Probably, different clinical results may be caused by the wide range in used dosages (range 1 to $45 \mathrm{mg}$ ) and time of administering leucovorin [daily (25) or e.g on three consecutive days (28)]. Recently the results of an uncontrolled study (22), were confirmed by a double-blind study (29). In this trial folic acid supplementation $1 \mathrm{mg}$ daily significantly lowered toxicity scores without affecting the efficacy of MTX during 6 
months of low-dose therapy with MTX (29). In case of pancytopenia due to MTX (7.5$15 \mathrm{mg} / \mathrm{wk}$ ), leucovorin has been recommended as a 'rescue' therapy, in dosages of four times $10-20 \mathrm{mg}$ daily until recovery occurs (30).

\subsection{CONTROLLED CLINICAL TRIALS OF MTX (See also Table 1)}

Double-blind trials of MTX compared with either placebo or with other second-line antirheumatic drugs in about $700 \mathrm{RA}$ patients have proven the clinical efficacy of MTX beyond all doubt. Beside significant decrease in articular indices and disease variables such as moming stiffness and pain scores, significant decreases in several laboratory values such as ESR $(31,32,33,34)$, rheumatoid factor (33) and immunoglobulins (31) were found. The percentage of withdrawals due to side effects of MTX was about $10 \%$ except for one study (30\%) (33).

Double-blind clinical trials in which MTX was compared with other second-line antirheumatic drugs comprise five studies, our clinical study of AZA versus MTX excluded (Chapter 6). In two studies of MTX versus parenteral gold, both drugs had the same clinical efficacy $(35,36)$. Side effects were more frequently found in patients treated with parenteral gold. Two studies in which azathioprine (AZA) was compared with MTX revealed the same clinical efficacy for AZA and MTX $(37,38)$. The numbers of patients studied in the latter two trials, however, were 100 small (42 and 34 respectively) for definite conclusions. Recently MTX was found to be more effective and better tolerated than oral gold (auranofin) (39).

In only one controlled clinical trial of MTX were radiographic data reported (37). Radiographic results from our double-blind study of AZA versus MTX are described in Chapter 7.

\subsection{LONG-TERM EXPERIENCE}

Using life table analysis the overall probability of continuing low-dose MTX in 152 RA patients was $70 \%$ after 1 year, $55 \%$ after 3 years and 50\% after 6 years (40). These percentages form a positive contrast to the overall probability of less than $20 \%$ of three other second-line antirheumatic drugs after 5 years: $19 \%$ for sulfasalazine, $17 \%$ for Dpenicillamine and $8 \%$ for parenteral gold (41). Toxic effects (30\%) rather than lack of effect $(8 \%)$ were the major reasons for discontinuation of MTX. Gastro-intestinal toxicity, elevated liver enzymes included, was the most common side effect in the long run. Only the occurrence of side effects independently affected the overall probability of continuation of MTX. Other factors such as age, sex, and disease severity failed to affect it $(42,43)$. 


\begin{tabular}{|c|c|c|c|c|}
\hline $\begin{array}{l}\text { Author } \\
\text { (ref) }\end{array}$ & $\begin{array}{l}\text { Number } \\
\text { of } \\
\text { patients }\end{array}$ & $\begin{array}{l}\text { Duration } \\
\text { study (wk) }\end{array}$ & $\begin{array}{l}\text { Dosage } \\
\text { (mg/wk) } \\
+ \text { drug }\end{array}$ & Comments \\
\hline $\begin{array}{l}\text { Thompson } \\
\text { (34) }\end{array}$ & 48 & $2 \times 6$ & $\begin{array}{l}10 \mathrm{i} . \mathrm{m}^{*} \\
\text { vs } 251 . \mathrm{m} \\
\text { vs placebo }\end{array}$ & $\begin{array}{l}\text { After } 6 \text { wk placebo group switched to MTX, other } \\
\text { groups continued MTX; MTX groups signif. impr. } \\
\text { in all (6) disease variables; ESR also signif. impr.; } \\
\text { Side effects } 30 \% \text {, Withdr. side effects } 4 \% . \$\end{array}$ \\
\hline $\begin{array}{l}\text { Andersen } \\
\text { (31) }\end{array}$ & 15 & $2 \times 13$ & $\begin{array}{l}10-25 * \\
\text { i.m } \\
\text { vs placebo }\end{array}$ & $\begin{array}{l}\text { - Crossover study; Signif. impr. in all (9) disease } \\
\text { variables; ESR and Iggs also signif. decrease. No } \\
\text { change in Latex, T-cells, and proliferation tests; } \\
\text { Side effects } 26 \% \text {, Withdr. side effects } 7 \% . \$\end{array}$ \\
\hline $\begin{array}{l}\text { Weinblatt } \\
\text { (32) }\end{array}$ & 35 & $2 \times 12$ & $\begin{array}{l}7.5-15 * \\
\text { oral } \\
\text { vs placebo }\end{array}$ & $\begin{array}{l}\text { - Crossover study; Signif. impr. in all (8) disease } \\
\text { variables but grip strength; ESR and grip strength } \\
\text { signif. decrease at } 24 \text { wk; Side effects 52\%, } \\
\text { Withdr. side effects } 3 \% \text {. }\end{array}$ \\
\hline $\begin{array}{l}\text { Williams } \\
\text { (33) }\end{array}$ & 186 & 18 & $\begin{array}{l}7.5-15 * \\
\text { oral } \\
\text { vs placebo }\end{array}$ & $\begin{array}{l}\text { Signif. impr. in all (13) disease variables; ESR and } \\
\text { Latex signif. decrease; Withdr. side effects } 30 \% \\
\text { (elevated liver enzymes most common). }\end{array}$ \\
\hline $\begin{array}{l}\text { Morassut } \\
\text { (36) }\end{array}$ & 35 & 26 & $\begin{array}{l}12.5 \mathrm{MTX} \\
\text { vs \# } \\
50.0 \mathrm{AU} \\
\text { i.m }\end{array}$ & $\begin{array}{l}\text { - Both drugs similar efficacy; Signif. impr. in } 9 \text { (AU) } \\
\text { and } 7 \text { (MTX) disease variables; ESR signif. de- } \\
\text { crease; Side effects MTX (35\%), AU (50\%), } \\
\text { Withdr. side effects MTX (11\%), AU (35\%). }\end{array}$ \\
\hline $\begin{array}{l}\text { Suarez } \\
\text { (35) }\end{array}$ & 40 & 26 & $\begin{array}{l}10.0 \mathrm{MTX} \\
\text { vs \# } \\
50.0 \mathrm{AU} \\
\text { i.m }\end{array}$ & $\begin{array}{l}\text { - Similar efficacy both drugs; Signif. impr. in } 8 \\
\text { (AU) and } 6 \text { (MTX) disease variables; ESR signif. } \\
\text { decrease; Signif. more withdr. side effects in AU } \\
\text { (33\%) than MTX (11\%). }\end{array}$ \\
\hline
\end{tabular}


Table 1. continued

\begin{tabular}{|c|c|c|c|c|}
\hline $\begin{array}{l}\text { Author } \\
\text { (ref) }\end{array}$ & $\begin{array}{l}\text { Number } \\
\text { of } \\
\text { patients }\end{array}$ & $\begin{array}{l}\text { Duration } \\
\text { study (wk) }\end{array}$ & $\begin{array}{l}\text { Dosage } \\
\text { (mg/wk) } \\
+ \text { drug }\end{array}$ & Comments \\
\hline $\begin{array}{l}\text { Weinblatt } \\
\text { (39) }\end{array}$ & 281 & 36 & $\begin{array}{l}7.5-15 \mathrm{MTX} \\
\text { oral } \\
\text { vs } 6.0-9.0 \\
\text { oral gold } \\
\quad \mathrm{mg} / \mathrm{d}\end{array}$ & $\begin{array}{l}\text { - Signif. impr. in all (8) disease variables in both } \\
\text { treatment groups; Response to MTX earlier and } \\
\text { signif. better; Side effects gold ( } 83 \%), \text { MTX } \\
\text { (73\%), Withdr. side effects gold ( } 44 \%) \text {, MTX } \\
(12 \%) .\end{array}$ \\
\hline $\begin{array}{l}\text { Hamdy } \\
(37)\end{array}$ & 42 & 52 & $\begin{array}{l}10-15 \mathrm{MTX} \\
\text { oral } \\
\text { vs } 100-150 \\
\text { AZA } \mathrm{mg} / \mathrm{d} \#\end{array}$ & - Similar efficacy AZA and MTX.@ \\
\hline $\begin{array}{l}\text { Bell } \\
(38)\end{array}$ & 34 & 20 & $\begin{array}{l}10-15 \mathrm{MTX} \\
\text { oral } \\
\text { vs } 100-150 \\
\text { AZA mg/d }\end{array}$ & - Similar efficacy AZA and MTX.@ \\
\hline
\end{tabular}

* Mg weekly methotrexate

\# AU = parenteral gold (mg weekly); AZA = azathioprine; MTX = methotrexate

\$ ESR = erythrocyte sedimentation rate; impr. = improvement; Latex = rheumatoid factor; signif. = significant; withdr. = withdrawal

@ More details are described in Table 2, Chapter 2 (Azathioprine) 


\subsection{ADVERSE REACTIONS}

An overview of the different adverse reactions to MTX is given in Chapter 4. Some additional information about central nervous system (CNS) toxicity, hematologic toxicity, the risk of infections due to MTX and hepatotoxicity will be presented in this paragraph.

CNS toxicity is a rare side effect of MTX. It comprises symptoms such as headache, dizziness, light-headedness and sometimes confusion and depression. CNS symptoms recurred after rechallenge with MTX in 5 RA patients (44).

With regard to hematological toxicity sustained elevation of MCV ( $>104 \mathrm{fl}$ ) was recently found to be a predictor of impending hematologic toxicity (45). The duration of MTX therapy in $6 \mathrm{RA}$ patients with hematologic toxicity (pancytopenia $n=3$; megaloblastic anemia, leucopenia, thrombocytopenia, all $n=1$ ) ranged between 13 and 62 months. Four of 6 patients received leucovorin, $10 \mathrm{mg}$ four times daily. Within 48 hours blood indices improved.

Whether the risk of infections is increased in RA patients treated with MTX is unknown. In several large scale (retrospective) studies, 2 to $4 \%$ of patients experienced minor or major (e.g sepsis) infections during MTX therapy $(42,46,47)$. In a case-control study no difference in number of infections between patients treated with azathioprine or MTX was found (47). From several studies there is lack of evidence of immunosuppressive properties i.c. influence on T-cells of low-dose MTX $(31,48)$. Reactivation of hepatitis B virus infection after discontinuation of MTX in one patient (49), Listeria meningitis in another patient (46) and Pneumocystis carinii infection in three patients $(50,51,52)$ suggest an impairment of the (cellular) immune function in individual patients. In a recent retrospective study it was shown that peri-operative MTX therapy did not increase the risk of local postoperative complications or poor wound healing in RA patients undergoing total joint arthroplasty (53).

The hepatotoxicity of low-dose MTX therapy in psoriasis has been established. The divergent percentages of fibrosis (4-35\%) and cirrhosis (0-25\%) in psoriasis patients treated with MTX are probably caused by differences in study design, dosage regimen and total weekly dosage of MTX, duration of follow-up and the presence of risk factors (see Chapter 4 and references 54,55,56,57). Furthermore fibrosis and cirrhosis in psoriatics not treated with MTX vary considerably (0-20\%). Rapidly progressive liver disease with clinically important cirrhosis (ascites, esophageal varices) due to MTX therapy was reported in four case studies $(58,59,60,61)$. A liver biopsy after a cumulative dosage of $1.5-2.0 \mathrm{~g}$ MTX is still being recommended by dermatologists (62) and gastroenterologists (54).

The lack of relevant MTX hepatotoxicity in RA patients after about 1.5-2.0 g MTX cumulatively, contrasts strongly with the reports in psoriasis (54). Probably, avoidance and awareness of risk factors (mainly alcohol abuse), lower weekly MTX dosage and speculatively- lesser propensity for liver damage in RA (54), may explain this observation.

There is agreement among rheumatologists not to perform a pre-MTX liver biopsy, unless there is doubt about pre-existent liver disease $(63,64,65,66,67)$. The necessity to 
Table 2. Hepatotoxicity and low-dose methotrexate (MTX) in rheumatoid arthritis

\begin{tabular}{|c|c|c|c|c|c|c|c|c|c|c|}
\hline $\begin{array}{l}\text { Author } \\
\text { (reference) }\end{array}$ & $\begin{array}{c}\text { Study } \\
\text { design } \\
0\end{array}$ & $\begin{array}{l}\text { Number } \\
\text { of } \\
\text { patients }\end{array}$ & $\begin{array}{l}\text { Weekly } \\
\text { dose MTX } \\
\text { in mg }\end{array}$ & $\begin{array}{l}\text { Mean dose } \\
\text { of MTX } \\
\text { cumulatively } \\
\text { (range) }\end{array}$ & $\begin{array}{l}\text { Fatty c } \\
\text { pre } \\
\text { MTX } \\
\text { (\% of }\end{array}$ & $\begin{array}{l}\text { hanges } \\
\text { post } \\
\text { MTX } \\
\text { atients) }\end{array}$ & $\begin{array}{l}\text { Fibrosis } \\
\text { pre }\end{array}$ & post & $\begin{array}{l}\text { Cirrh } \\
\text { pre }\end{array}$ & $\begin{array}{l}\text { osis } \\
\text { post }\end{array}$ \\
\hline $\begin{array}{l}\text { Di Bartholomeo } \\
\text { (71) }\end{array}$ & $\mathbf{p}$ & 26 & $7.5-22.5$ & \pm 1500 & $*$ & n.m & 0 & 0 & 0 & 0 \\
\hline $\begin{array}{l}\text { Mackenzie } \\
(72)\end{array}$ & $\mathbf{p}$ & 60 & $7.5-22.5$ & $\begin{array}{l} \pm 1800 \\
(500-4400)\end{array}$ & n.m & $6 \%$ & 0 & $\begin{array}{l}1.5 \\
\text { (IIIa) }\end{array}$ & 0 & 0 \\
\hline $\begin{array}{l}\text { Weinstein } \\
\text { (73) }\end{array}$ & $\mathbf{p}$ & 17 & $5.0-7.5$ & $\begin{array}{l} \pm 2000 \\
(915-3705)\end{array}$ & n.d & 71 & n.d & $\begin{array}{l}35 \\
\text { (II) }\end{array}$ & n.d & 0 \\
\hline $\begin{array}{l}\text { Koo } \\
(74)\end{array}$ & $\mathbf{p}$ & 82 & $2.5-12.5$ & $\begin{array}{l} \pm 3100 \\
(727-8400)\end{array}$ & n.d & n.d & 0 & $\begin{array}{l}5 \\
\text { (IIIa) }\end{array}$ & 0 & 0 \\
\hline $\begin{array}{l}\text { Lanse } \\
\text { (75) }\end{array}$ & $\mathbf{p}$ & 30 & $7.5-15.0$ & $\begin{array}{l} \pm 1500 \\
(227-6909)\end{array}$ & 37 & 37 & 13 & $\begin{array}{l}13 \& \\
\text { (gr n.m) }\end{array}$ & 0 & 0 \\
\hline $\begin{array}{l}\text { Tolman } \\
(76)\end{array}$ & $\mathbf{p}$ & 29 & 7.5 & $\frac{ \pm 1500}{(787-3355)}$ & n.d & n.d & n.d & $\begin{array}{l}33 \\
\text { (IIIa) }\end{array}$ & 0 & 0 \\
\hline $\begin{array}{l}\text { Aponte } \\
\text { (77) }\end{array}$ & $\mathbf{p}$ & 21 & $5.0-15.0$ & $\begin{array}{l} \pm 8800 \\
(4750-9990)\end{array}$ & n.d & 5 & n.d & $\begin{array}{l}25 \\
(\mathrm{IIIa} / \mathrm{b})\end{array}$ & n.d & 0 \\
\hline $\begin{array}{l}\text { Willkens } \\
\text { (78) }\end{array}$ & $\mathbf{p}$ & 59 & $\mathbf{n} \cdot \mathbf{m}$ & $\begin{array}{l} \pm 1500 \\
\text { (n.m) }\end{array}$ & n.d & 29 & n.d & $\begin{array}{l}21 \\
\text { (gr n.m) }\end{array}$ & n.d & 0 \\
\hline $\begin{array}{l}\text { Shergy } \\
\text { (79) }\end{array}$ & $\mathbf{r}$ & 210 & n.m & $\begin{array}{l} \pm 1500 \\
(1100-2500)\end{array}$ & n.d & n.d & n.d & $\begin{array}{l}3 \\
\text { (gr n.m) }\end{array}$ & n.d & 0 \\
\hline $\begin{array}{l}\text { Leonard } \\
(80)\end{array}$ & $\mathbf{r}$ & 29 & $7.5-15.0$ & $\begin{array}{l} \pm 1500 \\
(n . m)\end{array}$ & n.d & n.d & n.d & $\begin{array}{l}34 \\
\text { (IIIa) }\end{array}$ & n.d & 0 \\
\hline
\end{tabular}


Table 2. continued

\begin{tabular}{|c|c|c|c|c|c|c|c|c|c|c|}
\hline \multirow{2}{*}{$\begin{array}{l}\begin{array}{l}\text { Author } \\
\text { (reference) }\end{array} \\
\begin{array}{l}\text { Ytterberg } \\
\text { (81) }\end{array}\end{array}$} & \multirow{2}{*}{$\begin{array}{c}\begin{array}{c}\text { Study } \\
\text { design } \\
0\end{array} \\
p\end{array}$} & \multirow{2}{*}{$\begin{array}{l}\begin{array}{l}\text { Number } \\
\text { of } \\
\text { patients }\end{array} \\
22\end{array}$} & \multirow{2}{*}{$\begin{array}{l}\begin{array}{l}\text { Weekly } \\
\text { dose MTX } \\
\text { in } \mathrm{mg}\end{array} \\
10.0\end{array}$} & \multirow{2}{*}{$\begin{array}{l}\begin{array}{l}\text { Mean dose } \\
\text { of MTX } \\
\text { cumulatively } \\
\text { (range) }\end{array} \\
\pm 1000 \\
\text { (n.m) }\end{array}$} & \multicolumn{2}{|c|}{$\begin{array}{l}\text { Fatty changes } \\
\text { pre post } \\
\text { MTX MTX } \\
\text { (\% of patients) }\end{array}$} & \multicolumn{2}{|c|}{$\begin{array}{l}\text { Fibrosis } \\
\text { pre post }\end{array}$} & \multicolumn{2}{|c|}{$\begin{array}{l}\text { Cirrhosis } \\
\text { pre post }\end{array}$} \\
\hline & & & & & n.d & 5 & n.d & $\begin{array}{l}6 \\
(\mathrm{gr} n . \mathrm{m})\end{array}$ & n.d & 0 \\
\hline $\begin{array}{l}\text { Björkmann } \\
\text { (69) }\end{array}$ & $\mathbf{p}$ & 26 & n.m & $\begin{array}{l} \pm 2500 \\
(390-9100)\end{array}$ & n.d & 61 & n.d & $\begin{array}{l}15.4 \\
\text { (gr n.m) }\end{array}$ & n.d & 0 \\
\hline $\begin{array}{l}\text { Rau } \\
\text { (82) }\end{array}$ & $\mathrm{p}$ & 40 & $10.0-15.0$ & $\begin{array}{l} \pm 1300 \\
(200-3000)\end{array}$ & 17 & 17.5 & 15 & $\begin{array}{l}25 \\
(\text { IIIa/b) }\end{array}$ & 0 & 0 \\
\hline $\begin{array}{l}\text { Brick } \\
\text { (66) }\end{array}$ & p & 96 & $7.5-25.0$ & $1500-3400$ & 38 & 41 & 0 & $\begin{array}{l}3 \$ \\
\text { (IIIa) }\end{array}$ & 3 & 2 \\
\hline $\begin{array}{l}\text { Kremer } \\
\text { (65) }\end{array}$ & $p$ & 27 & $7.5-17.5$ & $1400-3700$ & 63 & $43-57$ & 0 & $\begin{array}{c}8-29 \\
(I I I a / b) \\
* *\end{array}$ & 0 & 0 \\
\hline
\end{tabular}

(1) $\mathrm{p}=$ prospective; $\mathrm{r}=$ retrospective

* Pre MTX liver biopsies in only 4 patients (grade I or II Roenigk classification (62))

\# Liver biopsy findings in a control group of 25 patients with severe RA

\& Pre MTX liver biopsies in 30 patients (9 RA, 18 psoriatic arthritis, 3 psoriasis)

\$ Pre MTX liver biopsies in 62 patients. Post MTX biopsies in 35 patients

** Measured annually after 2 years (26 patients) and 5 years (7 patients)

n.m Not mentioned; $n . d=$ not done

gr Grade of histologic abnormality in the liver according to the classification of Roenigk (62): grade I = normal; grade II = fatty infiltration, nuclear variability, portal inflammation; grade III = fibrosis mild (A) or severe (B); grade IV = cirrhosis 
obtain a liver biopsy after a cumulative dosage of $1.5-2.0 \mathrm{~g}$ MTX in RA patients, especially in those with no risk factors, remains an unsolved question. In 1987 the American College of Physicians recommended a liver biopsy after a cumulative dose of $1.5 \mathrm{~g}$ MTX (63). In the meantime these guidelines have been adjusted and the authors (68) now suggest to individualize the decision and to perform a liver biopsy after weighing the relative risk of a liver biopsy ( 1 in 10.000 fatal) against the risk of liver damage ( 1 in 1000). Other authors no longer perform biopsies in low risk patients (65) or delay their decision until a cumulative dosage of $2.5 \mathrm{~g}$ MTX (66).

In Table 2, fifteen recent, mostly prospective studies $(65,66,69-82)$ on MTX and liver histology in RA patients are listed. Several conclusions can be drawn from the results of liver biopsies in about 750 patients:

Firstly, no cirrhosis developed during MTX therapy. Secondly, there is a tendency to more fibrosis in the post-MTX group in some studies. Thirdly, the progression in fibrosis in some individual patients after sequential liver biopsies until 5 years was clinically unimportant (69). Additionally, in psoriatics with established cirrhosis who continued to use MTX, the course of the liver disease was mild and did not lead to overt liver disease (83). Fourthly, the experience in RA patients who have received a cumulative dosage of more than $2 \mathrm{~g}$ MTX is insufficient at this moment to allow determination of the ultimate effect of MTX on the liver after prolonged treatment (5-10 years). Therefore, long-term studies with serial liver biopsies are still needed.

MTX induced liver damage can only be detected reliable by liver biopsies. Other (noninvasive) tests such as repeated measurements of liver enzymes, hepatic ultrasonography and scans and aminopyrine breath tests are too insensitive $(57,61,64,79)$. The implication of electron microscopic findings (increased number of lysosomes and collagen deposition in the perisinusoidal spaces in the liver) in RA patients treated with MTX is still unclear (69). Acute reversible hepatic failure due to low-dose MTX in RA has been reported (85). Recently it was demonstrated that the concomitant use of (hydroxy)chloroquine and MTX decreases the hepatotoxicity of MTX (86). The mechanism of this interaction is speculative. Levels of (hydroxy)chloroquine in the liver are several hundred times higher than in plasma. Perhaps the inhibitory effect of (hydroxy)chloroquine on (hepatic) lysosomes plays a part in this interesting interaction (86).

In summary, when known risk factors with regard to hepatotoxicity of MTX are avoided, low-dose MTX therapy in RA is quite a safe treatment.

\subsection{FELTY'S SYNDROME}

Beside the data mentioned in Chapter 4 about the effect of MTX in extra-articular manifestations of RA such as Sjögren's syndrome and vasculitis, MTX was recently administered in another (uncommon) extra-articular feature of RA viz. Felty's syndrome. Felty's syndrome is characterized by splenomegaly and neutropenia. The cause of the neutropenia is probably multifactorial, e.g including abnormal chemotaxis, reduced release of polymorphonuclear leucocytes (PMNs) from bone marrow, shortened lifespan of PMNs, interaction of PMNs with immune complexes and presence of IgG neutrophil antibodies $(87,88)$. In three case studies $(89,90,91), 6$ RA patients with Felty's syndrome 
were successfully treated with low-dose MTX (5-7.5 mg weekly). An elevation of neutrophil counts occurred within 1-2 months after starting MTX. Recurrent infections ceased in the majority of these patients. MTX was also able to decrease IgG antineutrophil antibodies (89).

\subsection{FERTILITY, PREGNANCY, LACTATION}

MTX can pass the placenta and the drug has teratogenic properties (92). Three of eight pregnancies of women with RA, exposed to low-dose MTX in the first trimester, ended in spontaneous abortion (92). MTX has probably no effect on ovarian function in patients receiving high-dose MTX for malignancies $(93,94 a)$. Breast feeding during therapy with MTX is contraindicated because of potential toxicity (94b). In male patients with malignancy, severe oligospermia was observed, resolving after cessation of MTX therapy (95). Although there is one case report of MTX induced oligospermia on low-dose MTX (96), two other studies of 10 and 26 psoriasis patients respectively $(97,98)$ revealed no unfavourable effects of MTX on semen quantity and quality.

To our knowledge no oligospermia has been reported in RA patients treated with lowdose MTX. Recently impotence was described in three RA patients; it improved after discontinuation of MTX (99). In view of the established teratogenic effect of MTX, adequate contraception during MTX therapy is absolutely indicated. Congenital malformations due to MTX comprise features such as multiple skeletal abnormalities and even anencephaly $(100,101)$. There is no evidence of an increased incidence of congenital abnormalities in children born of women who have been treated with MTX in the past $(102,103)$.

\subsection{NEOPLASMS}

Large scale, partly retrospective, studies of psoriasis patients treated with low-dose MTX have revealed no increased incidence of malignancy $(104,105)$. In view of the increased incidence of neoplasms in RA patients, regardless of their treatment (see section Azathioprine 'neoplasms'), the question whether MTX causes an excess of malignancies in RA is unsolved. There are only two small, uncontrolled series of 59 and $78 \mathrm{RA}$ patients in which 6 and no neoplasms, respectively, were found $(107,108)$. One case report of a thymoma during MTX therapy has been published (108). Controlled, large scale studies concerning this issue are therefore highly necessary.

\section{REFERENCES}

1. Jolivet J, Cowan KH, Curt GA, Clindemann NJ, Chabner BA. The pharmacology and clinical use of methotrexate. N Engl Med 1983; 309: 1094-1104.

2. Bertino JR. The general pharmacology of methotrexate. In: Methotrexate Therapy in Rheumatic Disease. Wilke WS editor. 1st edition. New York, Basel; Marcel Dekker, 1989. 
3. Kremer JM, Galivan J, Streckfuss A, Kamen B. Methotrexate metabolism analysis in blood and liver of rheumatoid arthritis patients. Association with hepatic folate deficiency and formation of polyglutamates. Arthritis Rheum 1986; 29: 832-835.

4. Schröder H, Foged EK. Methotrexate in erythrocytes of patients with psoriasis. Eur J Clin Pharmacol 1986; 30: 453-456.

5. Furst DE, Herman R, Hoffmann J, Koehnke R, Veig-Pedersen P. Serum kinetics, synovial fluid levels and liver concentrations of methotrexate in 41 rheumatoid arthritis patients given methotrexate. Arthritis Rheum 1988; 31: (Suppl) D83 (Abstr).

6. Sinett MJ, Groff GD, Raddatz DA, Franck WA, Bertino JS. Methotrexate pharmacokinetics in patients with rheumatoid arthritis. J Rheumatol 1989; 16: 745-748.

7. Evans WE. Anticancer drugs in children. Clin Pharmacokin 1987; 12: 186-213.

8. Furst DE. Clinical Pharmacology of very low-dose methotrexate for use in rheumatoid arthritis. J Rheumatol 1985; 12: 11-14 (Suppl).

9. Ahern M, Booth J, Loxton A, McArthy P, Meffin P, Kevatt S. Methotrexate kinetics in rheumatoid arthritis: Is there an interaction with non steroidal anti-inflammatory drugs. J Rheumatol 1988; 15: 1356-1360.

10. Slördal L, Sager G, Aarbakke J. Pharmacokinetic interaction with methotrexate. Is 7hydroxymethotrexate the culprit? Lancet 1988; i: 591-592.

11. Kamel RS, Al-Hakun MH, Rademaker M, Meyrick Thomas RH, Munro DD. Pharmacokinetics of small doses of methotrexate in patients with psoriasis. Acta Derm Venereol 1988; 68: 267-270.

12. Darzynkiewicz Z, Rogers AW, Barnard EA. Autoradiography with tritiated methotrexate and the cellular distribution of folate reductase. Science 1966; 151: 1528-1530.

13. Chabner BA, Young RC. Threshold methotrexate concentration for in vivo inhibition of DNA synthesis in normal and tumorous target tissues. J Clin Invest 1973; 52: 1804-1811.

14. Edelmann J, Biggs DF, Fakhredden J, Russell AS. Low-dose Methotrexate kinetics in arthritis. Clin Pharmacol Ther 1984; 35: 382-386.

15a. Stoller RG, Handke KR, Jacobs SA et al. The use of plasma pharmacokinetics to predict and prevent methotrexate toxicity. N Engl J Med 1977; 297: 630-634.

15b. Bleyer WA. The clinical pharmacology of methotrexate. New application of an old drug. Cancer $1978 ; 41: 36-51$.

16. Tishler M, Caspi D, Graff E, Segal R, Peretz H, Yaron M. Synovial and serum levels of methotrexate during methotrexate therapy of rheumatoid arthritis. Br J Med 1989; 28: 422-423.

17a. Furst DE. Clinical Pharmacology of low-dose Methotrexate. In: Methotrexate Therapy in Rheumatic Disease. Wilke WS editor. Ist edition. New York, Basel; Marcel Dekker, 1989.

17b. Nuernberg B, Koehnke R, Solsky M, Hoffman J, Furst DE. Biliary elimination of lowdose methotrexate in humans. Arthritis Rheum 1990; 33: 898-902.

18. Sholar PW, Baram J, Seither R, Allegra CJ. Inhibition of folate dependent enzymes by 7 OH-methotrexate. Biochem Pharmacol 1988; 37: 3531-3534.

19. Jeurissen MEC, Boerbooms AMTh, van de Putte LBA. Pancytopenia and methotrexate with trimethoprim-sulfamethoxazole. Ann Intern Med 1989; 11: 261 .

20. Shiroky J, Watts CS, Neville C. Combination of methotrexate and sulfasalazine in the management of rheumatoid arthritis. Case observations. Arthritis Rheum 1989; 32: 11601164.

21. Mason DH, Furst DE. Methotrexate in rheumatoid arthritis and related diseases. Curr Opinion Rheum 1989; 1: 44-51.

22. Weinstein GD, Frost Ph. Methotrexate for psoriasis. A new therapeutic schedule. Arch Derm 1971; 103: 33-38.

23. Furst DE, Kremer JM. Methotrexate in rheumatoid arthritis. Arthritis Rheum 1988; 31: 305-314.

24. Morgan SL, Bagott JE, Vaughn WH, Austin J, Young P, Alarcón GS. Folic acid supplementation in methotrexate treated rheumatoid arthritis patients. A double-blind placebo controlled study. Arthritis Rheum 1989; 32: R40 (Abstr).

25. Morgan SL, Saway A, Alarcón GS. Folic acid treatment in methotrexate treatment in rheumatoid arthritis patients: Comment on the article by Furst and Kremer. Arthritis Rheum 1989; 32: 113-114.

26. Buckley LM, Cooper SM, Vacek PM. The use of leucovorin after low-dose methotrexate in patients with rheumatoid arthritis. Arthritis Rheum 1988; 31: S115 (Abstr). 
27. Hanrahan PS, Russell AS. Concurrent use of folinic acid and methotrexate in rheumatoid arthritis. J Rheumatol 1988; 15: 1078-1080.

28. Tishler $M$, Caspi D, Fishel $B$, Yaron $M$. The effects of leucovorin (folinic acid) on methotrexate therapy in rheumatoid arthritis patients . Arthritis Rheum 1988; 31: 906-908

29. Morgan S, Bagott JE, Vaughn WH, Young PK, Austin JV, Krumdieck CL. The effect of folic acid supplementation on the toxicity of low-dose methotrexate in patients with rheumatoid arthritis. Arthritis Rheum 1990; 33: 9-18.

30. Mackinnon SK, Starkebaum G, Willkens RF. Pancytopenia associated with low-dose pulse methotrexate in the treatment of rheumatoid arthritis. Semin Arthritis Rheum 1985; 15: 19-126.

31. Andersen PA, West SG, O'Dell JR, Via SS, Claypool, Kotzen BL. Weekly pulse methotrexate in rheumatoid arthritis. Clinical and immunological effects in a randomized double-blind study. Ann Intern Med 1885; 103: 489-496.

32. Weinblatt HJ, Coblyn JS, Fox DA et al. Efficacy of low-dose methotrexate in rheumatoid arthritis. N Engl J Med 1985; 312: 818-822.

33. Williams HJ, Willkens RF, Samuelson CO et al. Comparison of low-dose oral pulse methotrexate and placebo in the treatment of rheumatoid arthritis. Arthritis Rheum 1985; 28: 721-730.

34. Thompson RN, Watts C, Edelman J, Esdaille J, Russell AS. A controlled two-center trial of parenteral methotrexate therapy for refractory rheumatoid arthritis. J Rheumatol 1984; 11: 760-763.

35. Suarez-Almaroz ME, Fitzgerald A, Grace M, Russell AS. A randomized controlled trial of parenteral methotrexate compared with sodium aurothiomalate. J Rheumatol 1988; 15 : 753-756.

36. Morassut P, Goldstein R, Cyr M, Karsh J, McKendry R. Gold sodium thiomalate compared to low methotrexate in the treatment of rheumatoid arthritis. A randomized , double-blind study 26-week trial. J Rheumatol 1989; 16: 302-306.

37. Handy H, McKendry RJR, Mierins E, Liver JA. Low-dose methotrexate compared with azathioprine in the treatment of rheumatoid arthritis. Arthritis Rheum 1987; 30: 361-367.

38. Bell M, Chang Ch, Keystone EC, Urowitz MB, Gladman D, Ching Ch. A double-blind randomized controlled trial of azathioprine (AZA) and methotrexate (MTX) in the treatment of rheumatoid arthritis. Arthritis Rheum 1988; 31(Suppl): D72 (Abstract).

39. Weinblatt ME, Kaplan H, Germain BF, et al. Low-dose methotrexate compared with auranofin in adult rheumatoid arthritis. Arthritis Rheum 1990; 33: 330-338.

40. Alarcon GS, Tracy IC, Blackburn WD. Methotrexate in rheumatoid arthritis. Toxic effects as the major factor in limiting long-term treatment. Arthritis Rheum 1989; 32: 671-676.

41. Situnayke RD, Grindulis KA, McConkey B. Long-term treatment of rheumatoid arthritis with sulfasalazine, gold or penicillamine. A comparison using life table methods. Ann Rheum Dis 1987; 46: 177-183.

42. Fehlauer CS, Carson CW, Cannon GW et al. Methotrexate therapy in rheumatoid arthritis : 2-year retrospective follow-up study. J Rheumatol 1989; 16: 307-312.

43. Kremer JM, Lee JK. A long-term prospective study of the use of methotrexate in rheumatoid arthritis. Arthritis Rheum 1988; 31: 577-583.

44. Wernick K, Smith DL. Central nervous system toxicity associated with weekly low-dose methotrexate therapy. Arthritis RHeum 1989; 32: 770-775.

45. Weinblatt ME, Fraser P. Elevated mean corpuscular volume as a predictor of hematologic toxicity due to methotrexate therapy. Arthritis Rheum 1989; 32: 1592-96.

46. Gispen JG, Alarcón SA, Johnson JJ, Acton RT, O'Barger, Koopman WJ. Toxicity to methotrexate in rheumatoid arthritis. J Rheumatol 1987; 14: 74-79.

47. McKendry RJR, Cyr M. Toxicity of methotrexate compared with azathioprine in the treatment of rheumatoid arthritis. A case-control study of 131 patients. Arch Intern Med $1989 ; 149: 685-689$.

48. Olsen NJ, Callahan LF, Pincus Th. Immunologic studies of rheumatoid arthritis patients treated with methotrexate. Arthritis Rheum 1987; 30: 481-487.

49. Flowers MA, Heathcote J, Wanless JR et al. Fulminant hepatitis as a consequence of reactivation of hepatitis $B$ virus infection after discontinuation of low-dose methotrexate. Ann Intern Med 1990; 12: 381-382.

50. Perruquet JL, Harrington ThM, Davis DE. Pneumocystis carinii pneumonia following methotrexate therapy for rheumatoid arthritis. Arthritis Rheum 1983; 26: 1291-1292. 
51. Wallis PJ, Ryatt KS, Constable TJ. Pneumocystis carinii pneumonia complicating lowdose methotrexate treatment for psoriatic arthropathy. Ann Rheum Dis 1989; 48: 247249.

52. Leff RL, McKenzie R. Rheumatoid arthritis, methotrexate therapy and pneumocystis carinii pneumonia. Ann Intern Med 1990; 112: 716.

53. Perhala RS, Wilke WS, Clough JD, Segal AM. Local infectious complications following large joint replacement in rheumatoid arthritis patients treated with methotrexate versus those not treated with methotrexate. Arthritis Rheum 1991; 34: 146-152.

54. Lewis JH, Schiff E. Methotrexate-induced liver injury. Guidelines for detection and prevention. Am J Gastroenterology 1988; 12: 1337-1344.

55. Weinstein GD, Roenigk $\mathbf{H H}$, Maibach $\mathbf{H}$, Cosmides J, Halprin $\mathbf{K}$. Psoriasis-liverinteractions. Results of an international study. Arch Derm 1973; 108: 36-42.

56. Van de Kerkhoff PCM, Hoefnagels WHL, Van Haelst UJG, Mali JW. Methotrexate maintenance therapy and liver damage in psoriasis. Clin Exp Derm 1985; 10: 194-200.

57. Nyfors A. Liver biopsies from psoriatics related to methotrexate therapy. Findings in post methotrexate liver biopsies from 160 psoriatics. Acta Path Microb Scand 1977; 85: 511 518.

58. Coe RO, Bull FE. Cirrhosis associated with methotrexate treatment of psoriasis. J Am Acad Assoc 1968; 206: 1515-1520.

59. Muller SA, Farrow GM, Martalock DL. Cirrhosis caused by methotrexate in the treatment of psoriasis. Arch Derm 1969; 100: 523-530.

60. Epstein EG, Craft JD. Cirrhosis following methotrexate administration for psoriasis. Arch Derm 1969; 100: 531-534.

61. Reynolds FS, Lee WM. Hepatotoxicity after long-term methotrexate therapy. South Med J 1986; 79: 536-539.

62. Roenigk HH, Auerbach R, Maibach HI, Weinstein GD. Methotrexate guidelines revised. J Am Acad Derm 1982; 6: 145-155.

63. Tugwell $P$, Bennett $K$, Gent $M$. Methotrexate in rheumatoid arthritis. Indications, contraindications, efficacy and safety. Ann Intern Med 1987; 107: 305-312.

64. Szanto E, Sandstedt B, Kollberg B. Hepatotoxicity associated with low-dose, long-term methotrexate treatment of rheumatoid arthritis. Scand J Rheumatol 1987; 16: 229-234.

65. Kremer JM, Lee RG, Tolman KG. Liver histology in rheumatoid arthritis patients receiving long-term methotrexate therapy. A prospective study with baseline and sequential biopsies samples. Arthritis Rheum 1989; 32: 121-127.

66. Brick JE, Moreland LW, Al-Kawas F, Chang WL, Layne RO, Di Bartholomeo AG. Prospective analysis of liver biopsies before and after methotrexate therapy in rheumatoid arthritis. Semin Arthritis Rheum 1989; 19: 31-44.

67. Bridges SI, Alarcón GS, Koopman WJ. Methotrexate-induced liver abnormalities in rheumatoid arthritis. J Rheumatol 1989; 16: 1180-1183.

68. Tugwell P, Bennett K, Bell M, Gent M. Methotrexate in rheumatoid arthritis. Feedback on the American college of physicians guidelines. Ann Intern Med 1989; 110: 581-583.

69. Björkmann DJ, Hammond EH, Lee RG, O'Clegg DO, Tolman KG. Hepatic ultrastructure after methotrexate for rheumatoid arthritis. Arthritis Rheum 1988; 31: 1465-1472.

70. Kremer JM, Kaye GI. Electron microscopic analysis of sequential liver biopsy samples from patients with rheumatoid arthritis. Arthritis Rheum 1989; 31: 1202-1213.

71. Di Bartholomeo AG, Mayes $\mathbf{M}$, Bathon JM. Methotrexate in rheumatoid arthritis: $\mathbf{A}$ longitudinal study of liver biopsies. Arthritis Rheum 1984; 27: S61 (Abstract).

72. Mackenzie AH,. Hepatotoxicity of prolonged methotrexate therapy for rheumatoid arthritis. Clev Clin Q 1985; 52: 129-135.

73. Weinstein A, Marlowe S, Korn J. Low-dose methotrexate of rheumatoid arthritis. Longterm observations. Am J Med 1985; 79: 331-336.

74. Koo AP, Mackenzie AH, Tuthill RJ. Liver histology in rheumatoid arthritis before and prolonged methotrexate therapy. Arthritis Rheum 1985; 28: S14 (Abstract).

75. Lanse SB, Arnold GL, Gowans JD, Kaplan MM. Low incidence of hepatotoxicity associated with long-term, low-dose oral methotrexate in the Ireatment of refractory psoriasis, psoriatic arthritis and rheumatoid arthritis

Dig Dis Science 1985; 30: 104-109.

76. Tolman KG, Clegg DO, Lee RG, Ward JR. Methotrexate and the liver. J Rheumatol 1985; 12: 29-34.

77. Aponte I, Petrelli M. Histopathologic findings in the liver of rheumatoid arthritis patients treated with long-term bolus methotrexate. Arthritis Rheum 1988; 31: 1457-1464. 
78. Willkens RF, Clegg DO, Ward JR,. Liver biopsies in patients on low-dose pulse methotrexate. Arthritis Rheum 1985; 28: S77 (Abstract).

79. Shergy WJ, Polisson RP, Caldwell DS et al. Methotrexate-associated hepatotoxicity. Retrospective analysis of 210 patients with rheumatoid arthritis. Am J Med 1988; 85: 771-774.

80. Leonard PA, Clegg DO, Carson CC et al. Low-dose pulse methotrexate in rheumatoid arthritis. An 8-year experience with hepatotoxicity. Clin Rheumatol 1988; 6: 575-582.

81. Ytterberg SR, Knodell RG, Mahowald ML. Lack of methotrexate hepatotoxicity in rheumatoid arthritis. Contemp Gastroenterolog 1988; 1: 21-26.

82. Rau $R$, Karger Th, Herborn $G$, Franzel $H$. Liver biopsy findings in patients with rheumatoid arthritis undergoing long-term treatment with methotrexate. J Rheumatol 1989; 16: $489-493$.

83. Zachariae H, Kragballe K, Sögaard H. Methotrexate induced liver cirrhosis. Br J Med 1980; 102: 407-412.

84. Scully Ch J, Lundberg MS, Leonard PA. et al. The aminopyrine breath test for detecting hepatotoxicity in RA patients. Arthritis Rheum 1989; 32: R24 (Abstract).

85. Clegg DO, Furst DE, Tolman KG, Pague $R$. Acute reversible hepatic failure associated with methotrexate in the treatment of rheumatoid arthritis. J Rheumatol 1989; 16: 11231126.

86. Fries JF, Singh G, Lenert L, Furst DE. Aspirin, hydroxychloroquine, and hepatic enzymes abnormalities with methotrexate in rheumatoid arthritis. Arthritis Rheum 1990; 33: 1611-1619.

87. Breedveld FC, Fibbe WE, Hermans J, van der Meer J, Cats A. Factors influencing the incidence of infections in Felty's syndrome. Arch Intern Med 1987; 147: 915-920.

88. Breedveld FC, Lafeber GJM, de Vries E, Van Krieken JH, Cats A. Immune complexes and the pathogenesis of neutropenia in Felty's syndrome. Ann Rheum Dis 1986; 45: 696702.

89. Fiechtner JJ, Miller Dr, Starkebaum G. Reversal of neutropenia with methotrexate treatment in patients with Felty's syndrome. Correlation of response with neutrophilreactive IgG. Arthritis Rheum 1989; 32: 194-201.

90. Isasi C, Lopez-Martin JA, Trujilllo MA, Andrew JL, Palacio S. Felty's syndrome: response to low-dose methotrexate. J Rheumatol 1989; 16: 983-985.

91. Allen LS, Groff G. Treatment of Felty's syndrome with low-dose oral methotrexate. Arthritis Rheum 1986; 29: 902-905.

92. Kozlowski RD, Steinbrunner JV, Mackenzie AH, Clough JD, Wilke WS, Segal AM. Outcome of first-trimester exposure to low-dose methotrexate in eight patients with rheumatic disease. Am J Med 1990; 88: 589-592.

93. Shamberger RC, Rosenberg SA, Seipp CA, Sherins RJ. Effects of high-dose methotrexate and vincristine on ovarian and testicular functions in patients undergoing postoperative adjuvant treatment of osteosarcoma. Cancer Treatm Rep 1981; 65: 739-746.

94a. Rustin GJ, Booth M, Dent J. Pregnancy after cytotoxic chemotherapy for gestational trophoblastic tumors. Br J Med 1984; 288: 103-106.

94b. Clinical Pharmacokinetics. Drug Data Handbook 1990. Mammen GJ, editor. 2nd edition. Auckland; ADIS Press Limited, 1990.

95. Mathur U, Datta SL, Mathur BB. The effect of aminopterin induced folic acid deficiency on spermatogenesis. Fertil Steril 1977; 28: 1356-1360.

96. Sussmann A, Leonard JM. Psoriasis, methotrexate and oligospermia. Arch Dermatol 1980; 116: 215-217.

97. El-Beheiry A, El-Mansy E,, Kamel N, Salama N. Methotrexate and fertility in men. Arch Androlog 1979; 3: 177-179.

98. Grunnet E, Nyfors A, Brogaard Hansen $K$. Studies on human semen in topical corticosteroid treated and in methotrexate treated psoriatics. Dermatologica 1977; 154: 7884.

99. Blackburn WD, Alarcón GS. Impotence in three rheumatoid arthritis patients treated with methotrexate. Arthritis Rheum 1989; 32: 1341-1342.

100. Milunsky A, Graef JW, Gaynor MF. Methotrexate induced congenital malformations. J Pediatr 1968; 72: 790-795.

101. Powell HR, Ekert H. Methotrexate induced congenital malformation. Med J Austr 1971; 1076-77.

102. Ross GT. Congenital anomalies among children bom of mothers receiving chemotherapy for gestational trophoblastic neoplasms. Cancer 1976; 37: 1043-47. 
103. Blatt J, Mulvihill JJ, Zugler JL. Pregnancy outcome following cancer chemotherapy. Am J Med 1980; 69: 828-832.

104. Bailin PL, Tindall JP, Roenigk HH. Is methotrexate therapy for psoriasis carcinogenic? A modified retrospective-prospective analysis. J Am Med Assoc 1975; 232: 359-362.

105. Stern RS, Zierler S, Parrish JA. Methotrexate used for psoriasis and the risk of non cutaneous or cutaneous malignancy. Cancer 1982; 50: 869-872.

106. Willkens RF, Marks CR. Malignancies occurring during methotrexate treatment of rheumatoid arthritis. In: Biologically based immunomodulators in the therapy of rheumatic diseases. Pincus SH, Pisetsky DS, Rosewasser LJ eds. Elsevier Science Publishing Co 1986. New York, Amsterdam, London.

107. Hoffmeister RT. Methotrexate therapy in rheumatoid arthritis: 15 years experience. Am J Med 1983 (Suppl): 69-73.

108. Coburn KK, Cao JD. Thymoma associated with rheumatoid arthritis in a patient taking methotrexate. J Rheumatol 1986; 13: 437-439. 

Chapter 4

\section{METHOTREXATE THERAPY IN CONNECTIVE TISSUE DISEASES: A REVIEW OF THE LITERATURE}

M.E.C. Jeurissen, A.M.Th. Boerbooms and L.B.A. van de Putte

Department of Rheumatology, University Hospital, Nijmegen, The Netherlands

Neth J Med 1989; 35: 44-58 (Reproduced with permission) 



\subsection{ABSTRACT}

Low-dose methotrexate (MTX) therapy is now widely used with considerable success in refractory rheumatoid arthritis. Experience with the drug in other connective tissue diseases and vascultitis has been limited. This article reviews hypotheses about the mode of action of MTX, phamacology and pharmacokinetics, reasons to use cytotoxic agents in the different diseases, and results of MTX therapy. Risk factors, adverse reactions and drug interactions of MTX with other drugs are mentioned. Although based on a small number of patients, data about remarkable clinical improvement in polymyositis, systemic lupus erythematosus and vasculitis suggest that MTX is a potent and effective drug in connective tissue diseases other than rheumatoid arthritis. However, controlled trials are needed to assess the exact value of the drug in these diseases. Neth $J$ Med 1989; 35: 44-58.

Key words: Methotrexate; Rheumatoid arthritis; Collagen vascular disease

\subsection{INTRODUCTION}

Since 1980, many reports have been published concerning methotrexate (MTX) therapy in rheumatoid arthritis (RA) refractory to other slow-acting antirheumatic drugs, such as gold salts and D-penicillamine. Uncontrolled studies and short-term randomized trials have demonstrated the efficacy of MTX in RA with acceptable side effects (1-3).

Considering the enthusiasm and the number of reports on MTX administered in RA, it is surprising that controlled trials with MTX used in other connective tissue diseases (CTDs) are lacking. Experience with the drug in diseases such as polyarteritis nodosa (PAN) and systemic lupus erythematosus (SLE) has been limited to case reports. Polyand dermatomyositis are the only CTDs for which MTX has been administered in a larger number of patients.

The purpose of our article is to discuss the mechanism of action of MTX and review the literature about the pharmacology, pharmacokinetics and clinical use of MTX in RA, other CTDs and vasculitis. Furthermore, we discuss the drug interactions and adverse reactions of MTX. Finally, we make some recommendations about the use of MTX.

\subsection{HISTORY}

In 1948, childhood leukaemia was the first disease in which MTX was administered. In 1951, Gubner et al. (4) described a favourable effect of aminopterin in 3 patients with psoriasis, 3 out of 6 with psoriatic arthritis, 6 out of 7 with RA and one patient with lupus erythematosus (arthritis and skin lesions in remission).

The impressive results with corticosteroids, reported at the same time, probably overshadowed the interest in MTX until approximately 1980. The only reports of experience with MTX in RA published during this time were those by Gross et al. and Hofmeister $(5,6)$. Gross used a weekly intravenous dose of $50 \mathrm{mg}$ MTX according to the dosage 
recommended at that time by Miescher and Riethmüller ( 7 ) for collagen vascular diseases. During the 1960's MTX was successfully used in the treatment of severe, disabling psoriasis and the drug was approved for this indication by the Food and Drug Administration in 1971. Weinstein and Frost (8) recommended an intermittent regimen of MTX in three fractional doses at 12-hour intervals weekly. This regimen, based on the 37-h cell cycle of the psoriatic epidermal cell, is still used by many dermatologists and rheumatologists.

\subsection{ANIMAL STUDIES}

Immunosuppressive effects of high-dose MTX have already been reported in animals and in man $(9,10)$. MTX appeared to have a particular effect on the primary immune response ( $=$ cellular proliferative phase), but had little or no effect on secondary, delayed type hypersensitivity (11). Interpretation of the results of studies using different species of animal, different antigens and different modes of drug administration does, however, make extrapolation to human RA difficult. Several studies using animal models for polyarthritis, such as streptococcal wall arthritis and Freund adjuvant arthritis, have demonstrated the efficacy of MTX in suppressing the inflammation in joints and to some degree erosive damage (12-14). Inhibition of neutrophil chemotaxis induced by leukotriene B4 and complement C5a in a mouse model, using low-dose MTX, has been demonstrated (15). The same effect of MTX had already been described in patients with psoriasis (16). In rat adjuvant arthritis it was recently shown that MTX inhibited both the influx of activated macrophages into the synovium and also products of macrophage activation such as interleukin-1 (IL-1) and prostaglandin $E_{2}$ (17).

\subsection{HYPOTHESIS CONCERNING THE MECHANISM OF ACTION OF MTX}

The cell specific (S phase of DNA synthesis) effect on the rapidly proliferating psoriatic cell and inhibition of penetration of leukocytes into the epidermis are grounds for treating psoriasis with MTX $(8,16)$. However, the mechanism by which MTX decreases rheumatic synovitis has not been clearly identified. The synovitis in RA is a complex system of immune and inflammatory processes triggered by an unknown antigen. Several factors such as proteolytic enzymes, oxygen radicals, prostaglandins and lymphokines cause cartilage and bone damage. In this complex process the central and important role of the monocyte/macrophage as an antigen presenting cell to the $T$-cell has been established (18). Due to this close cell-to-cell interaction stimulated by interleukins, B-cells are triggered to proliferate and produce immunoglobulins.

In several studies MTX was shown to reduce the absolute number of circulating monocytes as compared with elevated pretreatment values $(19,20)$. However, no effect was demonstrated on elevated $\mathrm{T} 4 / \mathrm{T} 8$ ratios and in vitro proliferation responses of lymphocytes to mitogens $(22,23)$. In the study of Andersen et al. (22) and in our study (24), a 20 to $30 \%$ decrease in immunoglobulins was found. In one study a significant decrease in IgM rheumatoid factor (radioimmunoassay) was demonstrated (23).

Hypotheses about the mechanism of action of MTX postulated by various authors are: 
inhibition of progenitor cells of macrophage/monocyte localized in the bone marrow $(18,19)$, decrease of proliferation of synovial lining cells $(20)$, interference with chemotactic factors $(15)$, decrease of IL-1 synthesis $(17,25,26)$ and finally an inhibitory effect on activated macrophages $(17,26)$.

How MTX suppresses activity in other CTDs such as polymyositis (PM) and SLE is a matter for speculation. In 4 patients with CTD (3 SLE, 1 PM) MTX appeared to suppress the primary and secondary immune response associated with partial or complete remission (27).

The relatively rapid onset of MTX in RA (mostly within 4 to $8 \mathrm{wk}$ after initiation of treatment), together with the rapid relapse after discontinuation of MTX, suggests a more anti-inflammatory effect. The anti-inflammatory effect is possibly created by modulating the immune system due to influence on macrophages and/or lymphokines.

\subsection{PHARMACOLOGY AND PHARMACOKINETICS OF MTX}

MTX is classified as an antimetabolite due to folic acid antagonism. Competitive blockade of the enzyme dihydrofolate reductase (DHFR) causes inhibition especially of DNA synthesis and also RNA and protein synthesis (1). According to pharmacokinetic studies the serum level of MTX peaks about $2 \mathrm{~h}$ after oral or intramuscular administration. There is an important interindividual variation between the 24-h MTX serum concentration in the same patient when given orally or intramuscularly (28). Low-dose MTX kinetic studies in RA patients have revealed a triphasic half-life, resembling that in patients receiving high-dose MTX (29). RA patients receiving $7.5 \mathrm{mg}$ or $15 \mathrm{mg}$ weekly had about the same serum MTX levels $30 \mathrm{~h}$ after administration of the drug (30). Measurement of MTX serum levels in low-dose therapy is not of value in assessing the effective dosage in a patient, but may be of value in the case of a suspicion of toxicity (prolonged and high MTX levels) or in non-responders, who have very low MTX levels due to malabsorption (28).

MTX is a weak acid with a pKa in the range 4.8 to 5.5 (1). It can precipitate in acid urine. Renal toxicity due to precipitation of MTX can occur with high-dose MTX but very rarely in a low-dose regimen (1). Fifty to seventy percent of MTX is bound to protein, mainly albumin. Drug interactions owing to displacement of MTX from albumin binding sites, will be discussed below. With regard to the triphasic disappearance of MTX, the initial half-life of 1-2 $\mathrm{h}$ represents body distribution, the second (2-4 h) renal clearance and the third phase $(10 \mathrm{~h})$ enterohepatic circulation and redistribution from socalled third spaces as pleural and peritoneal cavities (31). In low-dose MTX therapy about $90-95 \%$ of the drug is found unchanged in the urine after $24-30 \mathrm{~h} \mathrm{(30)}$. At low plasma MTX levels tubular reabsorption exists. At higher levels the clearance of MTX exceeds that of inulin, indicating active tubular secretion as well as glomerular filtration (31).

The metabolite, 7-hydroxy MTX, found in the urine, may contribute to drug interactions and nephrotoxicity of high-dose MTX (31-33). The significance of that metabolite in low-dose MTX is unknown. Accumulation of MTX in the liver occurs chiefly in the form of polyglutamates (30). These metabolites can also inhibit the enzyme DHFR (31). 
Whether these polyglutamates and (severe) folate depletion are responsible for long-term toxicity is unclear $(34,35)$. Perhaps some depletion of folate levels is necessary for a clinical response to MTX (35). Theoretically, resistance to MTX can be caused by extrinsic defects (malabsorption) or intrinsic factors such as decreased affinity to DHFR and increased levels of DHFR (35). In RA patients treated with MTX, DHFR levels were markedly increased (36). However, no correlation was found between clinical efficacy of MTX and the levels of DHFR.

\subsection{DOSAGE OF MTX}

The oral dosage of MTX recommended for RA is 7.5 to $15 \mathrm{mg}$ weekly in one single dose or divided into three fractional doses at $12-\mathrm{h}$ intervals. Some authors have used a higher dosage of MTX (25 mg) (22). In a study of RA patients in which $10 \mathrm{mg}$ MTX was compared with $25 \mathrm{mg}$ parenterally, the higher dose was not found to produce better results (37). However, the follow-up of 12 wk was short. There are no trials evaluating advantages of intramuscular MTX as compared with oral MTX. In cases of malabsorption, doubts about patient compliance and in some cases of gastrointestinal complaints, the intramuscular route can be used instead of the oral.

The dosage of MTX administered in other CTDs such as polymyositis is mostly about $50 \mathrm{mg}$ weekly. That dose has been chosen empirically. It is recommended to increase the MTX dosage with weekly fractions of 10 to $15 \mathrm{mg}$ to the final dosage of $50 \mathrm{mg}$ (38). If the clinical situation has improved and stabilized, the frequency of drug administration can be reduced to biweekly or monthly. Although the intravenous route of MTX is sometimes used in the treatment of CTDs, there are neither convincing pharmacological data nor controlled trials to show that this route should be preferred to the intramuscular or the oral route (39).

\subsection{CLINICAL APPLICATION OF MTX: USE IN RHEUMATOID ARTHRITIS}

In uncontrolled trials comprising about $300 \mathrm{RA}$ patients who received $7.5-25 \mathrm{mg}$ MTX weekly, benefit has been found in 48 to $80 \%$ of patients with a distinct decrease in inflamed joints and erythrocyte sedimentation rate (1). Most of these studies lack prospective design and they differ in duration of follow-up, monitoring parameters and route of administration. In our own prospective open trial of MTX in refractory RA we found a statistically significant improvement in 12 of 14 patients with regard to clinical and laboratory variables, also after 12 months follow-up (24). Four placebo controlled and partly crossover trials of $300 \mathrm{RA}$ patients have been performed. These short-term trials (12-18 wk) were comparable with regard to in- and exclusion criteria and monitoring parameters $(22,37,40,41)$. The initial dose in these studies was $7.5 \mathrm{mg}$ and if required increased to $15 \mathrm{mg}$ after 6 wk. It was only in the study of Andersen (22) that the total dosage was increased to $25 \mathrm{mg}$. Calculations of the clinical benefit to the patients from these 4 controlled trials demonstrated a $39 \%$ reduction in pain, 37\% reduction of joint count for tenderness and swelling and $46 \%$ reduction in morning stiffness related to a $95 \%$ confidence interval (42). The ultimate question whether MTX 
is a disease modifying drug, i.e. whether the drug has the potential to retard radiographic progression, has to be evaluated in larger prospective trials. Kremer et al. have reported a disease modifying effect of MTX in an open prospective study in 7 of 11 patients after 2 yr of treatment (43). In the same patients a sustained clinical improvement was found, which reached a plateau after about 6 months. In another study, MTX was effective in suppressing disease activity in the long-term, but a disease modifying effect was not demonstrated (44). In our opinion the conclusion of Nordstrom et al. (44) had been based on findings of too small a patient group. Moreover, the measure points for assessing the radiographs showed (too) much inter- and intra-individual variability (45). Finally in a recent prospective study of 14 patients with a mean follow-up of 3 yr (range 2.5-3.5 yr), worsening of radiographs ( 6 patients), no change ( 3 patients) but also healing of erosions (5 patients) was observed (46).

\subsubsection{METHOTREXATE AND POLY- AND DERMATOMYOSITIS}

Polymyositis (PM) and Dermatomyositis (DM) are inflammatory disorders of striated muscle. The pathogenesis of PM and DM has still not been completely elucidated, but there is some evidence that cytotoxic lymphocytes take part in the process of muscle inflammation and injury (38). In patients with PM and pulmonary fibrosis an increased percentage of anti-Jo-1 antibodies has been found, but the significance of these and other antibodies is still uncertain $(38,47)$. Although not based on controlled studies, corticosteroids are the drugs of first choice in the treatment of PM/DM. The concurrent administration of cytotoxic agents such as azathioprine or MTX appears to be beneficial in suppressing immune mediated disease activity, steroid sparing effect or in cases of steroid resistance. A generally accepted definition of steroid resistance is lacking. Some authors define this point after $80 \mathrm{mg}$ prednisone, others after $40-60 \mathrm{mg}$, administered daily for 1-3 months (48-50). Retrospective studies of MTX therapy for PM/DM have been listed in Table 1. Bohan et al. (48) suggested a better clinical response to MTX than to azathioprine and cyclophosphamide. The results of Medzger et al. (49) were impressive, with clinical improvement in $77 \%$ of patients and a marked steroid sparing effect of $30 \mathrm{mg}$ prednisone daily after more than $1 \mathrm{yr}$ of treatment. In nearly all patients benefiting from MTX therapy, CPK values normalized, muscle strength improved and skin disease and/or dysphagia resolved.

Clinical response to MTX of PM/DM is reported between 4 to 20 wk after initiation of therapy. Normalization of muscle enzymes almost always precedes the improvement of muscle strength by several weeks. Pulmonary involvement in PM/DM is.an important cause of morbidity and mortality (47). Whether patients with PM/DM and pulmonary fibrosis have an increased risk of developing MTX pneumonitis, has to be evaluated. The prognosis of $\mathrm{PM} / \mathrm{DM}$ patients treated with different immunosuppressive agents is still limited. With a follow-up of about 7-8 yr the cumulative mortality varies between 28 and $47 \%$ (38). Prospective controlled trials are therefore necessary to evaluate the efficacy and safety of the different cytotoxic drugs especially MTX. 
Table 1.

Methotrexate therapy in polymyositis and dermatomyositis

\begin{tabular}{lllll}
\hline Author (year) & $\begin{array}{l}\text { Patients } \\
\text { with MTX } \\
\text { (mg } \\
\text { weekly) }\end{array}$ & $\begin{array}{l}\text { Patients } \\
\text { with } \\
\text { concurrent } \\
\text { prednisone } \\
\text { (mg daily) }\end{array}$ & $\begin{array}{l}\text { Average } \\
\text { follow- } \\
\text { up } \\
\text { (months) }\end{array}$ & Results \\
\hline Malaviya (1968) & $4(25-100)$ & $3(100-150)$ & 6 & $\begin{array}{l}4 \text { good clinical } \\
\text { improvement }\end{array}$ \\
Sokoloff (1971) & $7(35-60)$ & $6(10-80)$ & $4-5$ & 5 good response \\
Arnett (1973) & $5(25-50)$ & $5(20-50)$ & 7 & 4 good response \\
Metzger (1974) & $22(20-75)$ & $22(15-100)$ & 15 & $\begin{array}{l}17 \text { good response; } 5 \\
\text { no response. } \\
\text { Average reduction of } \\
\text { steroid by 35 mg } \\
\text { daily. }\end{array}$ \\
Bohan (1977) & 25 (avera- & $24(40)$ & 52 & $\begin{array}{l}16 \text { improved; } 6 \\
\text { ge 42) }\end{array}$ \\
& & & & $\begin{array}{l}\text { Average reduction of } \\
\text { steroids by } 25 \text { mg } \\
\text { daily. }\end{array}$ \\
\hline
\end{tabular}

\subsubsection{METHOTREXATE AND SYSTEMIC LUPUS ERYTHEMATOSUS}

SLE is an immunologically mediated multi-organ disorder associated with the presence of a variety of circulating auto-antibodies and characterized by antigen-antibody interaction, complement fixation and deposition of immune complexes in the tissues. A decreased number of T- and B-cells is a common manifestation in active SLE. In proliferative nephritis (Classes III and IV), inflammatory cells, mainly monocytes, are localized in the glomeruli. These cells may be partly responsible for the glomerular injury owing to release of proteolytic enzymes (54). Corticosteroids are still the drugs of choice in the treatment of SLE. Cytotoxic drugs, such as cyclophosphamide and azathioprine, can be beneficial in cases of nephritis, vasculitis, steroid resistance and undesirable steroid complications.

MTX has only sporadically been used in the management of SLE. In 1965, 10 patients with SLE were treated with i.v. MTX, 50 to $100 \mathrm{mg}$ weekly, with very rapid clinical improvement. Side effects were absent (7). Clinical improvement was reported in 6 SLE patients with severe systemic complications treated altemately with MTX $12.5-20 \mathrm{mg}$ weekly and azathioprine $1.5-2.0 \mathrm{mg} / \mathrm{kg} /$ day (55). Successful treatment of one patient with severe SLE (vasculitis, pleuro-pericarditis) has recently been reported (56). In another recent study with a follow-up of 4-30 months, 6 of 11 patients improved (7.5 mg MTX weekly) (57). Despite caution in cases of decreased renal function, it is worthwhile evaluating the efficacy of MTX in both cutaneous LE as SLE. 


\subsubsection{METHOTREXATE AND SCLERODERMA, SJÖGREN'S SYNDROME, MIXED CONNECTIVE TISSUE DISEASE}

As far as we know, MTX has not been administered in patients with Mixed CTD and primary Sjögren's syndrome. In one patient with RA and secondary Sjögren's syndrome treated with MTX, a favourable response of ocular manifestations was documented (58).

Experience with MTX in scleroderma has also been limited to one study (59). In that study two patients were described: one with CREST syndrome (calcinosis, Raynaud, oesophagus dysmotility, sclerodactyly, teleangiectasia) and the other with diffuse scleroderma. Both patients were also suffering from Sjogren's syndrome with biopsy proven lesions in salivary and parotid glands. The renal function was normal. In the second patient there was significant pulmonary fibrosis. In both patients the general condition, flexibility of the skin and Raynaud phenomenon improved with $25 \mathrm{mg}$ MTX biweekly (59).

\subsubsection{METHOTREXATE AND VASCULITIS}

The vasculitis in RA and SLE is mostly a leukocytoclastic vasculitis of the small vessels manifesting in cutaneous ulcers and/or purpura and nailfold lesions (60). In rare cases a severe vasculitis resembling PAN occurs. Vasculitis in RA is an expressions of the severity of the disease (61).

Treatment of the underlying disease (61) is essential in the management of the vasculitis. In less severe forms without imminent organ dysfunction corticosteroids alone can achieve complete remission. In cases of rapidly deteriorating organ function addition of cytotoxic drugs is recommended. The striking response and improved survival of patients suffering from Wegener's granulomatosis and treated with cyclophosphamide (2 $\mathrm{mg} / \mathrm{kg} / \mathrm{day}$ ) and corticosteroids (initially $1 \mathrm{mg} / \mathrm{kg} /$ day) have led to the use of that regimen for other forms of severe vasculitis (61).

However, trials comparing the efficacy and safety of the different cytotoxic drugs are lacking. Several case studies have reported successful treatment with MTX and corticosteroids in PAN (62-65), Wegener's granulomatosis (66), unclassified vasculitis and rheumatoid vasculitis $(65,67,68)$. In these patients MTX was administered in doses between 10 and $50 \mathrm{mg}$ weekly orally or parenterally. Tiliakos described the healing of severe rheumatoid ulcers unresponsive to cyclophosphamide and skin grafting with 10-15 mg MTX weekly. The ulcers as well as the synovitis disappeared within 45-100 days (67). Another study reported a dramatic clinical response to $10 \mathrm{mg}$ MTX weekly in 8 patients with rheumatoid vasculitis (68). In other vasculitis syndromes such as Behçet disease or giant cell arteritis, no studies of MTX treated patients are known to us. Contrary to the beneficial effect of MTX on vasculitis, one author reported induction of small vessel vasculitis due to low-dose MTX (69). Whether subcutaneous nodules develop in RA during MTX treatment is debatable. In a controlled trial nodules receded more often than they appeared (41). 


\subsection{RISK FACTORS, DRUG INTERACTIONS AND ADVERSE REACTIONS TO METHOTREXATE}

Risk factors. MTX toxicity depends on several factors such as duration of exposure to the drug, interval of dosage (daily more toxic than weekly) (2) and susceptibility of target tissues, especially those with high cell tumover like bone marrow and gastrointestinal epithelium. For each tissue there is a critical threshold level and minimal duration of exposure necessary for damaging that tissue (2). On the basis of large scale toxicity studies of psoriasis patients, the following risk factors were found to have an increased toxicity potential (70): diminished renal function (clearance $<50 \mathrm{ml} / \mathrm{min})(70,71)$, liver disease, alcoholism, leukopenia $\left(<3.5 \times 10^{9} / 1\right)$, thrombocytopenia $\left(<150 \times 10^{9} / 1\right)$, active peptic ulcer disease, active infections (e.g. pyelonephritis), obesity and diabetes mellitus. In RA the last two conditions are debatable as risk factors $(2,71,72)$. Development of hypalbuminaemia during MTX therapy as a predictor of liver disease has to be confirmed (42). The problem of pre-existent lung fibrosis will be discussed below.

Drug interactions. The mechanisms by which other drugs can increase the toxicity potential of MTX are: (a) displacement from albumin binding sites, (b) competition with renal tubular transport, (c) inhibition of renal excretion, and (d) impairment of MTX efflux from cells. In Table 2 the drugs are listed in which mechanisms (a) and (b) play an important role in drug interactions with MTX. The metabolite 7-OH-MTX (91-93\% bound to protein) is probably more involved in drug interactions than the parent compound $(50-60 \%$ bound to protein) $(33,73)$. Potentially nephrotoxic drugs such as aminoglycosides and amphotericin B decrease the renal excretion of MTX $(31,73)$. Simultaneous administration of low-dose MTX and NSAIDs rarely gives rise to nephrotoxicity (42). Reports about this side effect mainly concern high-dose MTX used in oncology (7577) or with pre-existent decreased renal clearance (79). Addition of diuretics to NSAIDs and MTX is potentially more dangerous (decrease of renal blood flow due to inhibition of renal prostaglandins). Examples of drugs impairing MTX efflux from cells are coumarin and probenecid (31). The combination of MTX with etretinate (vitamin A derivative) is probably more hepatotoxic (78).

In contrast with drugs increasing MTX toxicity, there are drugs which decrease the effect (and toxicity) of MTX due to several mechanisms such as reduction of intestinal absorption (non-absorbable antibiotics), inhibition of cellular uptake (hydrocortisone, folates, cephalotin), elevation of the enzyme DHFR (triamterene) and accumulation of intracellular purines (allopurinol) (73).

Adverse reactions (see Table 3). No HLA association between either side effects or clinical response to MTX has been found in RA patients (80-82). Gastrointestinal complaints (nausea, vomiting, diarrhoea) may be mild. In high-dose MTX severe gastrointestinal ulceration and haemorrhage have been reported (83). In low-dose therapy they are rare $(80,84)$. In cases with mild gastrointestinal symptoms one can diminish the dosage of MTX or try to administer MTX intramuscularly. 
Table 2. Drug interactions with MTX (increased toxicity potential)

Competition tubular secretion

NSAIDs

Sulphonamides

Diuretics

Penicillins

Probenecid
Displacement albumin

binding sites

1 Rarely in low-dose MTX therapy. The combination NSAIDs + diuretics + MTX is potentially more dangerous (see text).

2 Theoretically also additive folate antagonism.

3 Increased toxicity also due to inhibition of MTX efflux from the cell.

Elevation of liver enzymes was a frequent occurrence (10-58\%), but led to cessation of therapy in only $5 \%$ of cases (85). Liver function tests do not predict the presence or development of liver fibrosis/cirrhosis $(82,85,88)$. Levels of hepatic MTX polyglutamates or depleted hepatic folate levels do not correlate with either elevated liver enzymes or liver biopsy findings (30). It is recommended that MTX be temporarily discontinued, when elevated liver enzymes attain two to three times the normal value. In psoriasis patients there is probably an increased risk of hepatotoxicity after cumulative administration of 2-4 g MTX (86). Long-term studies in RA patients do not reveal increased liver toxicity after $2 \mathrm{~g}$ (= $5 \mathrm{yr}$ of $7.5 \mathrm{mg}$ MTX weekly) $(43,85,87)$. Although there are data on liver biopsy findings in RA patients treated with 3-4 g MTX as compared with a control RA group (87), the number of patients is insufficient to allow determination of the ultimate effect of MTX on the liver. Although debatable, it is still recommended to obtain a liver biopsy after a cumulative dose of $1.5-2 \mathrm{~g}$ MTX $(82,89)$.

The clinical picture of MTX pneumonitis is characterized by fever, non-productive cough, dyspnoea, bibasilar rales on auscultation and hypoxaemia $(90,91)$. The leukocyte count is mostly normal, with sometimes eosinophilia. Early in the course, the chest radiograph may be clear, but later on bilateral interstitial infiltrates develop and sometimes hilar adenopathy and pleural effusion. MTX pneumonitis has not been related to the cumulative dose, age or route of administration. The clinical course, together with the histological findings (93), suggests a hypersensitivity reaction. However, after rechallenge this side effect did not always recur (91). Pulmonary function tests after 2 years of MTX therapy have revealed no substantial changes (92). 
Table 3. Adverse reactions to methotrexate

\begin{tabular}{lcl}
\hline Frequent & Less frequent & Rare $(<1 \%)$ \\
\hline $\begin{array}{c}\text { Gastrointestinal } \\
(3-20 \%)\end{array}$ & Stomatitis & Nephrotoxicity \\
$\begin{array}{c}\text { Elevation liver enzymes } \\
(10-58 \%)\end{array}$ & $(2-10 \%)$ & Alopecia \\
& $(0-3 \%)$ & Dermal toxicity \\
& Pulmonary & Headache, dizziness \\
& $(0-5 \%)$ & Photosensitivity \\
& & Gynaecomastia \\
\hline
\end{tabular}

Possible predisposing risk factors (pre-existent lung disease, other pneumotoxic drugs) have to be further evaluated $(91,93)$.

Important risk factors in the development of haematological toxicity (leucopenia, thrombocytopenia, megaloblastic anaemia, pancytopenia) are: impaired renal function, decreased serum albumin, pre-existent marrow abnormality and concurrent other drugs, especially sulphonamides (94). The possible influence on human folate metabolism, displacement of albumin binding sites and inhibition of tubular secretion are factors responsible for drug toxicity between MTX and trimethoprim-sulphamethoxazole (Bactrimel) $(95,96)$.

Rare side effects are dermal toxicity (urticaria, erythema, impetiginous lesions), photosensitivity (97), gynaecomastia (98), oligospermia (99) and possibly increased susceptibility to infections (100). Because MTX is teratogenic, adequate birth control measures have to be taken. Finally at this time there is no evidence that MTX is a carcinogenic drug $(101,102)$, but further long-term prospective studies are necessary.

\subsection{CONCLUSIONS AND RECOMMENDATIONS}

In the past few years low-dose MTX (7.5-15 mg weekly) has become an important and effective second line drug in RA. The disease modifying effect of the drug, i.e. its potential to decelerate radiographic progression is not yet known because too few patients have been studied. The mechanism of action of MTX remains unclear, but it probably has anti-inflammatory and immune modulating properties. Although based on uncontrolled studies and sometimes a small number of patients, there are convincing data that MTX is a potent and effective drug in the treatment of several other rheumatic diseases and vasculitis. With the present knowledge of the pharmacology, drug interactions and risk factors and an adequate control scheme, the use of MTX in rheumatic diseases appears to be a quite safe procedure with acceptable side effects. Baseline blood and urine measurements should include: haemoglobin, leukocytes and differential count, platelets, hepatic enzymes, serum albumin, creatinine, ECC, urinalysis.

Various drug monitoring schedules have been proposed for MTX, but they differ considerably in the time required to perform the blood tests $(42,70,72,89,103)$. The guidelines we used in our department are partly based on the aforementioned schedules, but partly also on our own experience with MTX in RA. This control scheme is as 
follows: during the first 4 wk, blood cell counts, and in the second and fourth weeks, renal and liver function tests as well. Thereafter (if the values are normal), monthly blood tests for the following 5 months. After 6 months (if there is a stable situation), blood tests every 1-2 months.

Pre-treatment liver biopsies are only necessary in the case of suspected pre-existing liver disease. The need to perform a liver biopsy after a cumulative dose of more than $1500 \mathrm{mg}$ is debatable, but still recommended until more data are available $(82,89)$. Baseline chest radiograph and pulmonary function tests (for instance spirometry, $\mathrm{CO}$ diffusion, arterial blood gas analysis) should strongly be considered (42).

Adverse reactions focused on long and liver toxicity and the risk of malignancy have to be evaluated in long-term prospective studies.

\section{Acknowledgment}

We wish to thank Mrs. Marion Janssen for her excellent secretarial help.

\section{REFERENCES}

1. Letendre PW, De Jong DJ, Miller DR. The use of methotrexate in rheumatoid arthritis. Drug Intell Clin Pharm 1985; 19: 349-358.

2. Healy $\mathrm{AH}$. The current status of methotrexate use in rheumatoid diseases. Bull Rheum Dis 1986; 36: 1-10.

3. Boerbooms AMT. Methotrexate and rheumatoid arthritis. Clin Rheumatol 1985; 4: 387388.

4. Gubner R, August S, Ginsberg V. Therapeutic suppression of tissue reactivity. II. Effect of aminopterin in rheumatoid arthritis and psoriasis. Am J Med Sci 1951; 221: 176-182.

5. Gross $D$, Enderlen $M$, Fehr $K$. Die immunosuppressive Behandlung der progedient chronische Polyarthritis mit Antimetabolica and Cytostatica. Schweiz Med Wschr 1967; 97: 1301-1310.

6. Hoffmeister RT. Methotrexate in rheumatoid arthritis. Arthritis Rheum 1972; 15: 114.

7. Miescher PA, Riethmüller G. Diagnosis and treatment of systemic lupus erythematosus. Semin Hematol 1965; 2: 1-28.

8. Weinstein GD, Frost P. Methotrexate for psoriasis. A new therapeutic schedule. Arch Dermatol 1971; 103: 33-38.

9. Turk JL. Studies on the mechanism of action of methotrexate and cyclophosphamide on contact sensitivity in the guinea pig. Int Arch Allergy 1964; 24: 191-200.

10. Mitchell MS, Wade ME, De Conti RC, Bertino JR, Calabresi P. Immunosuppressive effects of cytosine arabinoside and methotrexate in man. Ann Int Med 1969; 70: 535-540.

11. Hurd ER. Immunosuppressive and anti-inflammatory properties of cyclophosphamide, azathioprine, and methotrexate. Arthritis Rheum 1973; 16: 84-88.

12. Ridge SC, Rath N, Galivan J, Zabriske J, Oronsky AL, Kerwar SS. Studies on the effect of D-penicillamine, gold thioglucose and methotrexate on streptococcal cell wall arthritis. J Rheumatol 1986; 13: 895-898.

13. Welles WL, Silkworth J, Oronsky AL, Kerwar SS, Galwan J. Studies on the effect of low-dose methotrexate on rat adjuvant arthritis. J Rheumatol 1985; 12: 904-906.

14. Crossley MJ, Spowage M, Hunneyball JM. Studies on the effect of pharmacological agents on antigen-induced arthritis in BALB/c mice. Drugs Exp Clin Res 1987; 5: 273277. 
15. Suarez CR, Pickett WC, Bell DH, McClintock DK, Oronsky AL, Kerwar SS. Effect on low-dose methotrexate on neutrophil chemotaxis induced by leukotriene $B$, and complement $C_{s .}$. J Rheumatol 1987; 14: 9-11.

16. Kerkhof van de PCM, Bauer FW, Massen-de Grood RM. Methotrexate inhibits the leukotriene $\mathrm{B}_{4}$ induced intra-epidermal accumulation of polymorphonuclear leukocytes.

Br J Dermatol 1985; 113: 251-255.

17. Johnson WJ, Dimartino MJ, Meunier PC, Muirhead KA, Hanna N. Methotrexate inhibits macrophage activations as well as vascular and cellular inflammatory events in rat adjuvant induced arthritis. J Rheumatol 1988; 15: 745-749.

18. Förre $O$, Waalen $K$, Thoen J, Hovig $T$. Macrophages and dendritic cells in rheumatic diseases. In: Gupta $S$, Talal $N$, eds. Immunology of rheumatic diseases. New YorkLondon: Plenum Medical Book Company, 1985; 543-562.

19. Johnston CA, Russell AS, Kovithavongs Th. Dasgupta M. Measures of immunologic and inflammatory responses in vitro in rheumatic arthritis treated with methotrexate.

J Rheumatol 1986; 13: 294-296.

20. Weinstein A. Mehotrexate: a prospective on its use for theumatoid arthritis. J Rheumatol 1985; suppl 12: 1-2.

21. Stevens JE, Willoughby DA. The anti-inflammatory effect of some immunosuppressive agents. J Pathol 1969; 27: 367-373.

22. Andersen PA, West SG, O'Dell JR, Via SS, Claypool RG, Kotzen BL. Weekly pulse methotrexate in rheumatoid arthritis. Clinical and immunological effect in a randomized double-blind study. Ann Intern Med 1985; 103: 489-496.

23. Olsen NJ, Callahan LF, Pincus Th. Immunologic studies of rheumatoid arthritis patients treated with methotrexate. Arthritis Rheum 1987; 30: 481-487.

24. Boerbooms AMT, Jeurissen MEC, Van de Putte LBA. Methotrexate in refractory rheumatoid arthritis. Clin Rheumatol 1988; 7: 249-256.

25. Miller LC, Dinarello CA. Methotrexate inhibits interleukin-1 activity. Arthritis Reum 1986; suppl S86: D20.

26. Hu SK, Mitcho Y, Oronsky AL, Kerwar SS. Studies on the effect of methotrexate on macrophage function. J Rheumatol 1988; 15: 206-209.

27. Swanson MA, Schwartz RS. Immunosuppressive therapy. The relation between clinical response and immunologic competence. N Engl J Med 1967; 277: 163-170.

28. Freeman-Narrod M, Gerstly BJ, Engstrom PF, Bornstein YS. Comparison of serum concentrations of methotrexate after various routes of administration. Cancer 1975; 36 : 1619-1624.

29. Christophides N, Louis WJ, Lucas I, Moon W, Vogda Fye. Renal clearance of methotre$x$ ate in man during high-dose oral and intravenous infusion therapy. Cancer Chemother Pharmacol 1981; 6: 59-64.

30. Kremer JM, Galivan J, Streckfuss A, Kamen B. Methotrexate metabolism analysis in blood and liver of theumatoid arthritis patients. Arthritis Rheum 1986; 29: 832-835.

31. Schornagel JH, McVie JG. The clinical pharmacology of methotrexate. Cancer Treatm Rev 1983; 10: 53-75.

32. Jacobs SA, Stoller RG, Chabner BA, Johns DG. 7-Hydroxymethotrexate as a urinary metabolite in human subjects and rhesus monkeys receiving high-dose methotrexate.

J Clin Invest 1976; 57: 534-538.

33. Slördal L, Sager G, Aarbakke J. Pharmacokinetic interactions with methotrexate: is 7 hydroxymethotrexate the culprit? Lancet 1988; 12: 591-592.

34. Kamen BA, Nylen PA, Camitta BM, Bertino JR. Methotrexate accumulation and folate depletion in cells as possible mechanism of chronic toxicity to the drug. Br J Haematol 1981; 49: 355-360.

35. Morgan SL, Bagott JE, Altz-Smith M. Folate status of rheumatoid arthritis patients receiving long-term, low-dose methotrexate therapy. Arthritis Rheum 1987; 30: 13481356.

36. Rodenhuis SJ, Kremer JM, Bertino JR. Increase of dihydrofolate reductase in peripheral blood lymphocytes of rheumatoid arthritis patients treated with low-dose oral methotrexate. Arthritis Rheum 1987; 30: 369-374.

37. Thompson RN, Watts C, Edelman J, Esdaile J, Russell AS. A controlled two-centre trial of parenteral methotrexate therapy for refractory theumatoid arthritis. J Rheumatol 1984; 11: $760-763$. 
38. Kagen LJ. Polymyositis/Dermatomyositis. In: McCarthy DJ, ed. Arthritis and allied conditions. Philadelphia: Lea \& Febiger 1985; 971-993.

39. Christophides N, Huskisson EC. Methotrexate therapy in steroid resistant polymyositis: a clinical and pharmacokinetic study (abstract). Ann Rheum Dis Heberden Society 1982; 315.

40. Weinblatt ME, Coblyn JS, Fox DA, et al. Efficacy of low-dose methotrexate in rheumatoid arthritis. N Engl J Med 1985; 312: 818-822.

41. Williams HJ, Willkens RF, Samuelson CO, et al. Comparison of low-dose oral pulse methotrexate and placebo in the treatment of rheumatoid arthritis. Arthritis Rheum 1985; 28: $721-730$.

42. Tugwell P, Bennett K, Gent M. Methotrexate in rheumatoid arthritis. Indications, contraindications. Efficacy and safety. Ann Int Med 1987; 107: 358-366.

43. Kremer JM, Lee JK. The safety and efficacy of the use of methotrexate in long-term therapy for rheumatoid arthritis. Arthritis Rheum 1986; 29: 822-831.

44. Nordstrom DM, West SW, Andersen PA, Sharp JT. Pulse methotrexate therapy in rheumatoid arthritis. A controlled prospective roentgenographic study. Ann Intern Med 1987; 107: 797-801.

45. Boerbooms AMT, Jeurissen MEC, Van de Putte LBA. Pulse methotrexate therapy in rheumatoid arthritis (letter to the editor). Ann Intrn Med 1988; 108: 905.

46. Weinblatt ME, Trentham DE, Fraser PA, Holdsworth DE, Folchuk KR, Weissman BN, Coblyn JS. Long-term prospective trial of low-dose methotrexate in rheumatoid arthritis. Arthritis Rheum 1988; 31: 167-175.

47. Hochberg MC, Feldman D, Stevens MB. Adult onset polymyositis/dermatomyositis: an analysis of clinical and laboratory features and survival in 76 patients with a review of the literature. Semin Arthritis Rheum 1986; 15: 168-178.

48. Bohan A, Peter JB, Bowman RL. A computer assisted analysis of 153 patients with polymyositis and dermatomyositis. Medicine 1977; 56: 255-285.

49. Metzger AL, Bohen A, Goldberg LS, Bluestone R, Pearson CM. Polymyositis and dermatomyositis: combined methotrexate and corticosteroid therapy. Ann Int Med 1974; 81: $182-189$.

50. Ansell BM. Management of polymyositis and dermatomyositis. In: Clinics in rheumatic diseases. Inflammatory disorders of muscle. London-Philadelphia: WB Saunders Company 1984; 10: 205-213.

51. Malaviya HN, Many A, Schwartz RS. Treatment of dermatomyositis with methotrexate. Lancet $1968 ; 2: 485-488$.

52. Sokoloff MC, Goldberg LS, Pearson CM. Treatment of corticosteroid resistant polymyositis with methotrexate. Lancet $1971 ; 1: 14-17$.

53. Arnett FC, Whelton JC, Zizic TM. Methotrexate therapy in polymyositis. Ann Rheum Dis 1973; 32: 536-546.

54. Pollak VE, Pirani CL. The kidney in systemic lupus erythematosus. In: Wallace DJ, Dubois EL, eds. Dubois' lupus erythematosus. Philadelphia: Lea \& Febiger, 1987: 105129.

55. Cruchaud A, Pometta D, Rousso C. Treatment of systemic lupus erythematosus with immunosuppressive drugs. Helv Med Acta 1967; 34: 5-22.

56. Davidson JR, Graziano FM, Rothenberg RJ. Methotrexate therapy for severe systemic lupus erythematosus. Arthritis Rheum 1987; 30: 1195-1196.

57. Rothenberg RJ, Graziano FM, Grandone JT, Goldberg JW, Bjarnason DF, Finesilver AG. The use of methotrexate in steroid-resistant systemic lupus erythematosus. Arthritis Rheum 1988; 31: 612-615.

58. Scharf JM, Meyer E, Nahir M, Zonis S. Effects of immunosuppressive drugs on the morphology of the microvilli in Sjögren's syndrome. Scand J Rheumatol 1986; suppl 61: 215-219.

59. Welin J, Grolleau JY, Barriere H. Scleroderma and Gougerot-Sjōgren syndrome. Effect of methotrexate therapy. Sem Hôp Paris 1973; 49: 37-41.

60. Fauci AS. Vasculitis. In: McCarthy DJ, ed. Arthritis and allied conditions. Philadelphia: Lea \& Febiger, 1985; 942-961.

61. Christian CL, Sergent JS. Vasculitis syndromes: clinical and experimental models. Am J Med 1976; 61: 385-392.

62. Tannenbaum H. Combined therapy with methotrexate and prednisone in polyarteritis nodosa. Can Med Assoc 1980; 123: 893-894. 
63. Leib ES, Restivo C, Paulus HE. Immunosuppressive and corticosteroid therapy of polyarteritis nodosa. Am J Med 1979; 67: 941-947.

64. Fraga A, Mintz G, Orozco JH. Immunosuppressive therapy in connective tissue diseases other than rheumatoid arthritis. J Rheumatol 1974; 1: 374-391.

65. Mitchell MS, Gifford RH, Bertino JR, Kenney JD, Malawista SE. The treatment of disseminated vasculitis with methotrexate. Inflammation 1976; 1: 285-295.

66. Capizzi RL, Bertino JR. Methotrexate therapy of Wegener granulomatosus. Ann Int Med 1971; 74: 74-79.

67. Tiliakos N. Pulse methotrexate therapy for intractable rheumatoid cutaneous ulcers. Arthritis Rheum 1985; suppl.28: S37.

68. Espinoza LR, Espinoza CG, Vasey FB, Germain BF. Oral methotrexate therapy for chronic rheumatoid arthritis ulcerations. J Am Acad Dermatol 1986; 15: 508-512.

69. Marks CR, Willkens RF, Wilske RR, Brown PB. Small vessel vasculitis and methotrexate. Ann Intern Med 1985; 103: 612-613.

70. Roenigk HH, Auerbach R, Maibach HI, Weinstein GD. Methotrexate guidelines-revised. J Am Acad Dermatol 1982; 6: 145-155.

71. Wilke WS, Mackenzie AH. Methotrexate therapy in theumatoid arthritis. Drugs 1986; 32: $103-113$.

72. Furst DE, Kremer JM. Methotrexate in rheumatoid arthritis. Arthritis Rheum 1988; 31: 305-314.

73. Evans WE, Christensen ML. Drug interactions with methotrexate. J Rheumatol 1985; 12: 15-20.

74. Bell MJ, Geddie WR, Gordon OA, Reynolds WJ. Pre-existing lung disease in patients with rheumatoid arthritis may prednisone to methotrexate lung. Arthritis Rheum 1986; suppl: S75.

75. Thijss A, Kubar J, Milano G, Namer M, Schneider M. Clinical and pharmacokinetic evidence of a life-threatening interaction between methotrexate and ketoprofen. Lancet 1986; 256-258.

76. Maiche AG. Acute renal failure due to concomitant action of methotrexate and indomethacin. Lancet 1986; i: 1390.

77. Singh RR, Malavya AN, Pandy JN, Guleria JS. Fatal interaction between naproxen and methotrexate. Lancet 1986; 1: 1390.

78. Zachariae H. Dangers of methotrexate/etrinitate combination therapy. Lancet $1988 ; 422$.

79. Brussaard HE, Van Eijk CLA, Van Toorn DW, Van Seters WA, De Wit RFE. Acute bone marrow suppression during treatment with low doses of methotrexate. Ned Tijdschr Geneeskd 1987; 131: 2369-2372.

80. Gispen JG, Alarcón GS, Johnson JJ, Acton RT, Barger BO, Koopman WJ. Toxicity to methotrexate in rheumatoid arthritis. J Rheumatol 1987; 14: 74-79.

81. Alarcón GS, Billingsley LM, Clegg DO, et al. Lack of association between HLA-DR2 and clinical response to methotrexate in patients with rheumatoid arthritis. Arthritis Rheum 1987; 30: 218-220.

82. Kremer JM, Lee JK. A long-term prospective study of the use of methotrexate in rheumatoid arthritis. Arthritis Rheum 1988; 31: 577-584.

83. Nesbit M, Krivit W, Heyn R, Sharp $H$. Acute and chronic effects of methotrexate on hepatic, pulmonary and skeletal systems. Cancer 1976; 37: 1048-1054.

84. Weinblatt ME. Toxicity of low-dose methotrexate in rheumatoid arthritis. J Rheumatol 1985; 12: 35-39.

85. Leonard PA, Clegg DO, Carson CC, Cannon GW, Egger MJ, Ward JR. Low-dose pulse methotrexate in rheumatoid arthritis: an 8 year experience with hepatotoxicity. Clin Rheumatol 1987; 6: 575-582.

86. Bookbinder SA, Espinoza LR, Fenske NA, Germain BF, Vasey FB. Methotrexate: its use in rheumatic diseases. Clin Exp Rheumatol 1984; 2: 185-193.

87. MacKenzie AH. Hepatotoxicity of prolonged methotrexate therapy for rheumatoid arthritis. Cleveland Clin Q 1985; 52: 129-135.

88. Szanto E, Sandstedt B, Kollberg E. Hepatotoxicity associated with low-dose, long-term methotrexate treatment of rheumatoid arthritis. Scand J Rheumatol 1987; 16: 229-234.

89. Health and Public Policy Committee, American College of Physicians. Methotrexate in rheumatoid arthritis. Ann Int Med 1987; 107: 418-419.

90. St.Clair EW, Rice JR, Snyderman R. Pneumonitis complicating low-dose methotrexate therapy in rheumatoid arthritis. Arch Int Med 1985; 145: 2034-2038. 
91. Carson CW, Cannon GW, Egger MJ, Ward JR, Clegg DO. Pulmonary disease during the treatment of rheumatoid arthritis with low-dose pulse methotrexate. Semin Arthritis Rheum 1987; 16: 186-195.

92. Tebib JG. Pulmonary management in methotrexate therapy of rheumatoid arthritis. Proceedings European Congress Rheum. Athens, 1987; P545.

93. Searles G, Mckendry RJR. Methotrexate pneumonitis in rheumatoid arthritis. Potential risk factors. Four case reports and a review of the literature. J Rheumatol 1987; 14: 1164-1171.

94. Mackinnon SK, Starkebaum G, Willkens RF, Pancytopenia associated with low-dose pulse methotrexate therapy of rheumatoid arthritis. Semin Arthritis Rheum 1985; 15: 119 126.

95. Thomas MH, Gutterman LA. Methotrexate toxicity in a patient receiving trimethoprimsulfamethoxazole. J Rheumatol 1986; 13: 440-441.

96. Maricic M, Davis M, Gall EP. Megaloblastic pancytopenia in a patient receiving concurrent methotrexate and trimethoprim-sulfamethoxazole treatment. Arthritis Rheum 1986; 29: 133-135.

97. Neiman RA, Fye K. Methotrexate induced false photosensitivity reaction. J Rheumatol 1985; 12: 334-335.

98. Del Paine DW, Leek JC, Jakle C. Gynaecomastia associated with low-dose methotrexate therapy. Arthritis Rheum 1983; 26: 691-692.

99. Susman A, Leonard JM. Psoriasis, methotrexate and oligosperma. Arch Dermatol 1980; 16: $215-217$.

100. Clements PJ, Davis J. Cytotoxic drugs. Their clinical application to the rheumatic diseases. Semin Arthritis Rheum 1986; 15: 231-254.

101. Bailin PL, Tindall JP, Roenigk HH. Is methotrexate therapy for psoriasis carcinogenic? A modified retrospective-prospective analsysis. J Am Med Assoc 1975; 232: 359-362.

102. Stern RS, Zierler S, Parrish JA. Methotrexate used for psoriasis and the risk of noncutaneous or cutaneous malignancy. Cancer 1982; 50: 869-872.

103. Wilkse KR, Campbell PM. Network Physician Organization and guidelines for reviewers of rheumatic disease care. Bull Rheum Dis 1987; 37: 1-10. 

Chapter 5

\title{
METHOTREXATE IN REFRACTORY RHEUMATOID ARTHRITIS
}

\begin{abstract}
A.M.Th. Boerbooms, M.E.C. Jeurissen, A.A.A. Westgeest, H. Theunisse, L.B.A. van de Putte

Department of Rheumatology, Academic Hospital Nijmegen, Geert Grooteplein Zuid 8, 6525 GA Nijmegen, The Netherlands.
\end{abstract}

Clin Rheumatol 1988; 7: 249-256 (Reproduced with permission) 



\subsection{ABSTRACT}

Fourteen patients with severe theumatoid arthritis refractory to hydroxychloroquine, gold-thioglucose, D-penicillamine and azathioprine completed a 6-month open study with oral methotrexate ( 2.5 to $5 \mathrm{mg}$ every 12 hours, three doses weekly). Twelve of them were followed up for 12 months. Compared with pretreatment values, there was a significant reduction in duration of morning stiffness $(p<0.01)$, in the number of tender or painful joints $(p<0.02)$, number of swollen joints $(p<0.01)$, visual analog scale, patient's assessment of joint discomfort and overall well-being $(p<0.01)$ after 2 , 6 , and 12 months. Likewise there was an improvement in the erythrocyte sedimentation rate $(p<0.001), C$-reactive protein $(p<0.01)$ and the levels of $\operatorname{IgG}, \operatorname{IgM}$ and $\operatorname{IgA}$ $(p<0.01)$. Two patients were withdrawn from the study, one for severe diarrhoea and one because of a depression. Adverse reactions during methotrexate therapy included nausea (5/16) and transaminase elevation (4/16). We conclude that this pilot study provides evidence that a weekly low-dose of methotrexate is effective in the short-term treatment for patients with rheumatoid arthritis, refractory to hydroxychlomquine, aurothioglucose, D-penicillamine and azathioprine.

Key words: Refractory Rheumatoid Arthritis, Methotrexate, Immunoglobulins

\subsection{INTRODUCTION}

Methotrexate (MTX), a folic acid antagonist, has already been used in the treatment of rheumatoid arthritis (RA) as early as 1951 (1). In spite of favourable effects of MTX, it was not until after 1980 that further reports in open (2-4) and double-blind controlled (58) studies were published. In all these studies the patients had previous therapeutic failure or unacceptable side effects with gold salts and/or D-penicillamine. In West European countries patients of this category are usually treated with azathioprine and less often with cyclophosphamide (9-11).

We report the antirheumatic efficacy and safety and the associated immunoglobulin changes during low-dose oral weekly methotrexate for patients with severe adult onset rheumatoid arthritis in whom hydroxychloroquine, gold-thioglucose, D-penicillamine and azathioprine had failed to produce a response or had been toxic.

\subsection{PATIENTS AND METHODS}

\section{Patients}

Sixteen patients with classical or definite rheumatoid arthritis according to the American Rheumatism Association criteria (12) gave informed consent and entered into the predetermined protocol. All patients were Caucasian. Clinical characteristics of the patients studied are given in Table I. All patients had previously been treated with hydroxychloroquine, gold-salt therapy, D-penicillamine and azathioprine. These drugs had 
Table 1. Characteristics of the $\mathbf{1 6}$ patients at the study entry

$\begin{array}{lc}\text { Age (yr) } & 59 \\ \text { mean } & 45-70 \\ \text { range } & 9 / 7 \\ \text { Female/male } & 16 \\ \text { Disease duration (yr) } & 5-33 \\ \text { mean } & \\ \text { range } & 7 \\ \text { Functional class } & 9 \\ \text { II } & \\ \text { III } & 14 \\ \text { Rheumatoid factor } & 14 \\ \text { Latex } \geq 1 / 80 & 9 \\ \text { Waaler Rose } \geq 1 / 64 & 5 \\ \text { HLA-DR4 positive } & 8 \\ \text { Previous hip, knee or shoulder } & 16 \\ \text { arthroplasty } & 5 \\ \text { Prednisone ( } \leq 10 \text { mg daily) } & \\ \text { NSAIDs } & \end{array}$

been discontinued because of ineffectiveness or toxicity. Except in cases of toxicity, each of these second-line antirheumatic drugs had been given for at least 6 months. Other criteria for entry were onset of the disease after the age of 16 and the presence of active disease, defined by at least 6 tender joints or painful on motion and 3 swollen joints and one of the following two features, 45 minutes of morning stiffness or a Westergren erythrocyte sedimentation rate (ESR) $\geq 28 \mathrm{~mm} /$ hour. All of the patients were taking contraceptive precautions if appropriate. Excluded from the study were patients with a history of renal, liver or cancer disease, liver enzyme levels 2 times the upper limit of normal, abnormal serum creatinine levels ( $\geq 120 \mu \mathrm{mol} / 1)$, insuline-dependent diabetes, alcoholism, active peptic ulcer disease, white cell counts $<3.5 \times 10^{9} / 1$, platelet count $<150 \times 10^{9} /$ and functional class IV according to the criteria of Steinbrocker et al. (12).

Concomitant use of nonsteroidal anti-inflammatory drugs (NSAIDs) was permittted. Dosage of these drugs was kept constant from one month prior to the start of MTX therapy until the end of the study period. A maximum dose of $10 \mathrm{mg}$ prednisone daily was allowed. Decrease of the dose was allowed during the study. All changes on dose of prednisone were recorded. The study protocol was approved by the Ethics Committee of the hospital.

\section{Administration of MTX}

MTX tablets of $2.5 \mathrm{mg}$ were ingested in equal numbers on three consecutive occasions at 12-hour intervals beginning on the same day of each week. For the first 8 weeks, three tablets were taken weekly. At 8 weeks thereafter the dose could be increased to six tablets weekly if no satisfactory response was noted by the investigator. Satisfactory response was defined as a decrease of at least 30 percent compared with the pretreatment values of all of the following clinical disease variables: 1) duration of morning stiffness, 2) Ritchie articular index, 3) the patient's overall assessment of disease activity and well- 
being on a visual analog scale (VAS). In case of side effects the doses could be diminished to $5 \mathrm{mg}$ weekly, given on two doses of $2.5 \mathrm{mg} 12$ hours apart.

\section{Clinical assessments}

Each patient was examined monthly for 6 months and then every 2 months by the same investigators (AB or $\mathrm{HT}$ ). The clinical disease variables determined at each visit consisted of: 1) duration of moming stiffness, 2) the patient's overall assessment of disease activity and well-being on a visual analog scale (VAS) of $10 \mathrm{~cm}$ with a score of 10 being the worst $(100 \%)$ and 0 being absent or normal $(0 \%)$ respectively, 3) number of diarthrodial joints with swelling, 4) number of joints with tendemess on pressure and/or pain on passive motion, 5) Ritchie articular index (13), 6) functional class according to Steinbrocker $(14), 7)$ daily prednisone consumption in $\mathrm{mg}$. Joints with prosthesis or ankylosis and joints which received intra-articular injections during the study were excluded from analysis.

\section{Laboratory assessments}

Laboratory tests for drug toxicity were obtained every week during the first month, monthly during the following 5 months and then every 2 months. These tests included haemoglobin concentration $(\mathrm{Hb})$ leucocyte count and white blood cell differentiation, platelet counts, serum levels of creatinine, serum glutamic oxaloacetic transaminase, glutamic pyruvic transaminase and alkaline phosphatase. Serum was also analyzed for titers of rheumatoid factor (Latex fixation and Waaler-Rose test), C-reactive protein (radioimmunodiffusion assay), Westergren erythrocyte sedimentation rate (ESR), concentrations of immune complexes by a Clq-binding assay (15), quantitative determination of immunoglobulin levels of IgG, IgM and IgA class (16); urinalysis of protein excretion were performed every 2 months.

The mean ESR of the patients one year before entering the study was $59 \mathrm{~mm} / \mathrm{h}$. The ESR was measured every 2 months. Methotrexate was withheld, if the white blood cell count decreased below $3.5 \times 10^{9} / 1$, the platelet count decreased below $150 \times 10^{9} / 1$, the creatinine level rose above $130 \mu \mathrm{mol} / 1$, or liver enzymes increased to more than twice the upper limit of normal. These tests were repeated weekly until normalisation of the test(s). Thereafter methotrexate therapy was restarted in an equal or lower dose.

\section{HLA typing}

HLA typing was done with standard NIH microlymphocytotoxicity techniques. DR typing was done on B-lymphocyte enriched suspensions obtained after rosetting with AET-treated sheep red blood cells. A control group consisting of 66 patients with definite or classical RA were also DR typed (17). All sera were standardized according to the 8th and 9 th International Histocompatibility Workshop sera. 
Table 2. Clinical and laboratory changes (mean \pm SEM) at entry and after 2 and 6 months methotrexate treatment in 14 patients

\begin{tabular}{|c|c|c|c|c|c|}
\hline Variable & Entry & 2 months & $\mathbf{P}$ & 6 months & $\mathbf{P}$ \\
\hline $\begin{array}{l}\text { Duration of morning stiffness } \\
\text { (min) }\end{array}$ & $98 \pm 22$ & $52 \pm 17$ & $<0.002$ & $47 \pm 16$ & $<0.01$ \\
\hline $\begin{array}{l}\text { No. of joints tender to pressure } \\
\text { or painful on passive motion }\end{array}$ & $21.3 \pm 3.7$ & $14.5 \pm 3.1$ & $<0.02$ & $14.1 \pm 3$ & $<0.01$ \\
\hline Ritchie-articular index & $20.1 \pm 3.2$ & $12.4 \pm 2.4$ & 0.001 & $12.2 \pm 2.2$ & $<0.01$ \\
\hline No. of swollen joints & $16.9 \pm 1.5$ & $11 \pm 0.9$ & 0.001 & $10.8 \pm 1.8$ & $<0.01$ \\
\hline $\begin{array}{l}\text { Visual analog scale joint dis- } \\
\text { comfort and overall well-being } \\
(0-100 \%)\end{array}$ & $63.8 \pm 5.1$ & $38.2 \pm 3.2$ & 0.002 & $36.8 \pm 7.3$ & $<0.01$ \\
\hline $\begin{array}{l}\text { Westergren sedimentation rate } \\
(\mathrm{mm} / \mathrm{h})\end{array}$ & $65.6 \pm 8.2$ & $37.4 \pm 4.3$ & 0.001 & $33.8 \pm 7.1$ & $<0.001$ \\
\hline C-reactive protein (mg/l) \# & $45.9 \pm 6.5$ & $26.1 \pm 6.5$ & 0.01 & $16.0 \pm 3.9$ & $<0.01$ \\
\hline Hemoglobin (mmol/l) & $7.2 \pm 0.4$ & $7.4 \pm 0.3$ & NS & $7.8 \pm 0.3$ & NS \\
\hline $\begin{array}{l}\text { Immunoglobulin levels }(\mathrm{g} / \mathrm{l}) * \\
\text { IgG } \\
\text { IgM } \\
\text { IgA }\end{array}$ & $\begin{aligned} & 16.8 \pm 1.4 \\
& 2.9 \pm 0.5 \\
& 3.6 \pm 0.3\end{aligned}$ & $\begin{aligned} 14.6 \pm 1.3 \\
2.5 \pm 0.5 \\
3.1 \pm 0.2\end{aligned}$ & $\begin{array}{c}<0.01 \\
0.002 \\
0.001\end{array}$ & $\begin{array}{r}13.0 \pm 1.0 \\
2.3 \pm 0.4 \\
2.8 \pm 0.3\end{array}$ & $\begin{array}{l}<0.002 \\
<0.01 \\
<0.002\end{array}$ \\
\hline Prednisone (mg/day) & $5.0 \pm 5.0$ & $5.0 \pm 1.5$ & NS & $3.5 \pm 1.2$ & NS \\
\hline
\end{tabular}

\# Normal serum C-reactive protein $<8.6 \mathrm{mg} / \mathrm{l}$

* Normal serum immunoglobulin concentrations (mean $\pm \mathrm{SD}$ ): $\mathrm{IgG} 12.5 \pm 2.1 \mathrm{~g} / \mathrm{l}, \mathrm{IgM} 1.1 \pm 0.4 \mathrm{~g} / \mathrm{l}, \mathrm{IgA} 2.0 \pm 0.6 \mathrm{~g} / 1$ 


\section{Statistical analysis}

Continuous disease variables were analyzed using the Student's t-test for paired samples, comparing changes after 2,6 and 12 months therapy with the entry visit in the same patients. A value of $<0.05$ was considered to be statistically significant.

\subsection{RESULTS}

\section{Patients and study course}

Sixteen patients fulfilled the 4 entry criteria of active disease and started with MTX therapy. Fourteen patients completed 6 months of the protocol and 12 patients completed 12 months. Two of 16 patients were excluded from analysis due to side effects. One patient was withdrawn because of diarrhoea two weeks after initiation with methotrexate and one was withdrawn after 2 months of therapy because of complaints from depression. Two other patients were withdrawn because of unsatisfactory results after 6 months of therapy. The weekly doses of methotrexate could be maintained at $7.5 \mathrm{mg}$ during the study in 9 patients. It had to be increased to $15 \mathrm{mg}$ in 3 patients because of inefficacy and decreased to $5 \mathrm{mg}$ in 2 patients because of side effects.

All patients had concomitant medication of NSAIDs. The prednisone dosage could be decreased in 4 patients (Table 2).

\section{Effects on disease}

Significant improvement occurred in 12 of the 14 patients who were followed over a 6month period. In comparison with entry values improvement was noted at months 2 and 6 in the duration of moming stiffness, the number of joint discomfort and overall wellbeing. Also the erythrocyte sedimentation rate and the $\mathrm{C}$-reactive protein improved significantly. Haemoglobin was slightly increased from 7.2 (SEM 0.4) to 7.8 (SEM 0.3) after 6 months of methotrexate therapy (Table 2).

Figure 1 and 2 show the clinical and laboratory improvement in the 12 patients who were followed-up for 12 months. A marked improvement in these patients was already seen after one month of therapy increasing up to 6 months; thereafter changes were minimal

\section{Changes in serologic tests}

No significant changes in mean rheumatoid factor titres and Clq-binding were associated with methotrexate therapy. Rheumatoid factor titers decreased in the Latex fixation test by two tube dilutions in 3 patients and increased by 2 tube dilutions in one patient during the treatment with methotrexate. All the immunoglobulin levels in the patients studied were increased before methotrexate therapy and decreased significantly after methotrexate treatment. Decreases of serum IgG, IgM, IgA levels were respectively 
Figure 1. Mean changes in selected clinical variables in 12 patients after methotrexate therapy.

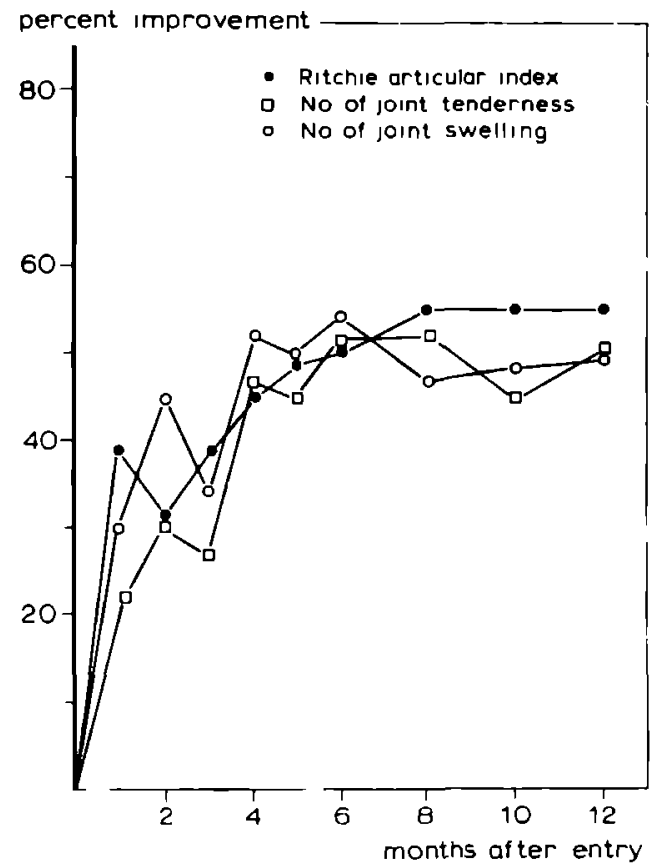

$23 \%, 21 \%$ and $22 \%$ after 6 months of methotrexate therapy in 14 patients. The decrease of the immunoglobulins in the 12 patients with a follow-up of 12 months showed a progressive decrease till approximately 6 months (Figure 2). Only the IgG and IgA levels decreased to normal values.

No difference in HLA-DR4 frequency between these RA patients ( 9 out of the 16, $56 \%$ ) and the RA control group (36 out of the 66, 55\%) was found.

\section{Toxicity}

Serious side effects during methotrexate therapy were noticed in one patient who developed severe diarrhoea after 2 weeks of methotrexate therapy (cumulative dose 15 $\mathrm{mg}$ ). Without the drug the diarrhoea resolved during a six-day hospitalization. Methotrexate therapy was not restarted in this patient. Another patient developed a depression; after 3 months the methotrexate therapy was restarted, but now intramuscularly. The depression did not disappear after stopping MTX. During 12 months of methotrexate therapy, 8 of 16 patients $(50 \%)$ had one or more types of adverse reactions, chiefly gastrointestinal or elevated transaminase levels (Table III). These side effects were mild and disappeared after the medication was decreased or withheld for a short period. 


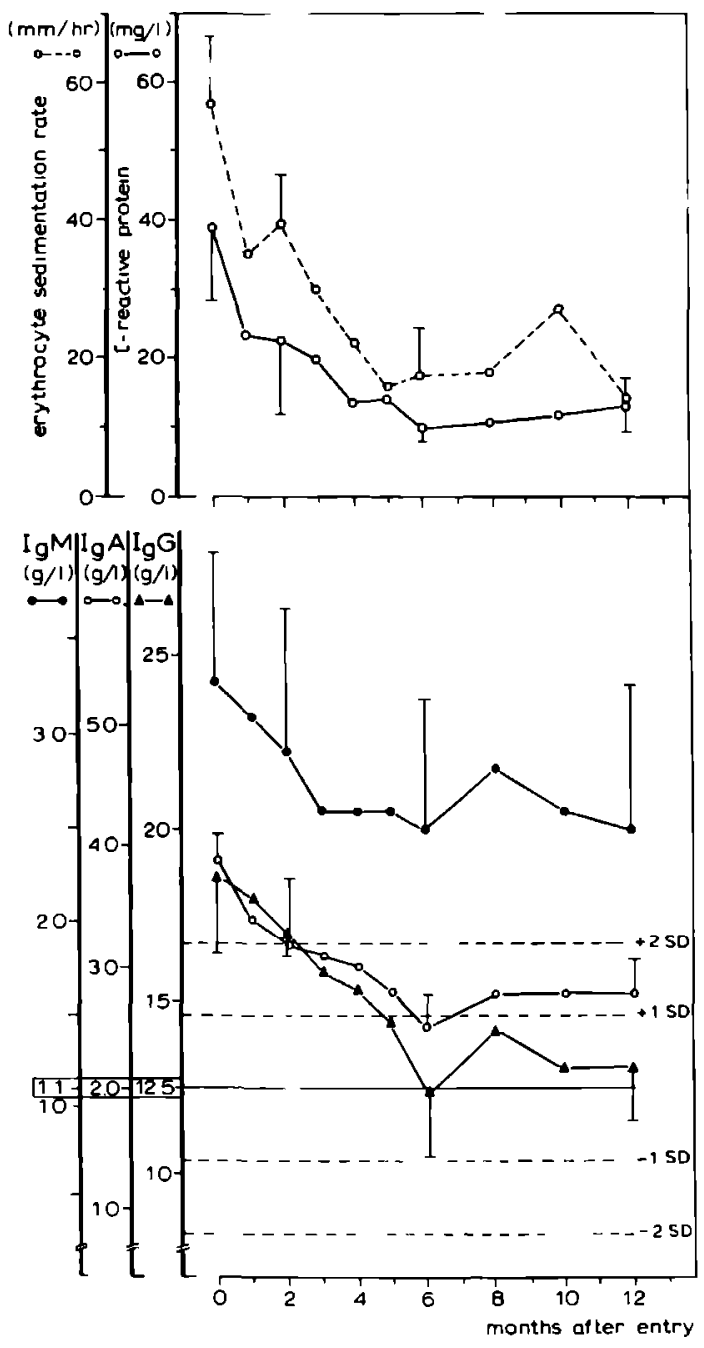

Figure 2.

Time sequence of changes in erythrocyte sedimentation rate, C-reactive protein, IgM, IgA and IgG serum levels. Data are presented as mean ( \pm SEM) for twelve patients. Normal level CRP $<8.6 \mathrm{mg} / \mathrm{l}$. The horizontal continuous line represents the mean immunoglobulin levels.

\subsection{DISCUSSION}

Treatment of patients with severe longstanding rheumatoid arthritis refractory to hydroxychloroquine, gold-salt, D-penicillamine and azathioprine is a difficult problem. Data on treatment with methotrexate for these groups of patients are lacking. In this prospective open study, most of these patients treated with a weekly low-dose methotrexate therapy showed a marked clinical improvement after 2, 6 and 12 months. The results of this study were in accordance with uncontrolled (2-4) and controlled (5-8) reports, in which the patients were at least resistant to gold and/or D-penicillamine. 
Table 3. Adverse reactions and withdrawals during methotrexate therapy in 16 patients

\begin{tabular}{|c|c|c|}
\hline Adverse reaction & No. of patients & $\begin{array}{l}\text { No. of withdrawals } \\
\text { (months after MTX) }\end{array}$ \\
\hline $\begin{array}{l}\text { Elevated transaminase } \\
\text { Nausea } \\
\text { Vomiting } \\
\text { Diarrhoea } \\
\text { Abdominal pain } \\
\text { Anorexia } \\
\text { Headache } \\
\text { Depression }\end{array}$ & $\begin{array}{l}4(25 \%) \\
5(31 \%) \\
1 \\
1 \\
1 \\
1 \\
1 \\
1\end{array}$ & $1(1 / 2)$ \\
\hline
\end{tabular}

Improvement of all clinical variables measured was associated with a decreased erythrocyte sedimentation rate, C-reactive protein and immunoglobulin levels IgG, IgM and IgA. Decreases of IgG, IgM, IgA in approximately the same magnitude, as in our study, were also described by Andersen et al. (5) in a double-blind methotrexate-placebo study. It was not, however, established in a double-blind methotrexate-azathioprine trial (18), but in that study the exact values of immunoglobulin levels were not noted. A possible reason for the difference in results could be the fact that the immunoglobulins were not or less increased at the start of methotrexate. Two patients did not complete the 6 month study, one because of severe diarrhoea and one because of depression, the latter probably not being related to methotrexate therapy. Two other patients were withdrawn because of unsatisfactory results after 6 months therapy. Gastrointestinal problems (31 percent) and transaminase elevation (25 percent) were the most common adverse reactions to methotrexate in this open study. These side effects disappeared after diminishing the methotrexate dosage.

Reported frequencies of minor side effects as stomatitis, nausea, abdominal cramps, diarrhoea, malaise and liver function test abnormalities ranged from $6.25 \%$ to $63.9 \%$ $(5,7,19)$. The close control of the patients which enabled us to detect early signs of toxicity and stop the medication and the small number of patients in our study may explain why the most serious side effects that can occur with low-dose methotrexate administration, e.g. bonemarrow suppression (20) or acute pulmonary toxicity $(21,22,23)$ were absent. The dosage schedule selected for this study was based on experience with methotrexate treatment of psoriasis. Weinstein and Frost (24) suggested a regimen of 3 doses weekly at 12 -hour intervals to provide a pharmacologic effect for the 37-hour cycle of rapid psoriatic cell tumover. However, there appears to be little difference in therapy for patients with psoriasis between this regimen and that in which methotrexate is given in a single weekly dose (20). To our knowledge there is no double-blind study in patients with rheumatoid arthritis, in which a series of three divided doses administered on an intermittent oral schedule over a 36-hour period each week is compared with a single weekly oral dose.

Only in 3 out of the 12 patients with a follow-up of 12 months was the dosage increased from 7.5 to $15 \mathrm{mg}$ methotrexate after 2 months of therapy. In the double-blind 
placebo-methotrexate multicentre study of Williams et al. (8) the dosage was increased after 6 weeks of therapy in $2 / 3$ of the patients. There were many differences, however, among their patient population and ours.

In conclusion, this open pilot study shows that patients with rheumatoid arthritis, unresponsive to or with a toxic reaction to hydroxychloroquine, gold, D-penicillamine and azathioprine and able to tolerate low-dose pulse methotrexate therapy, improved significantly with methotrexate therapy. Side effects were common, but mild, except in one patient with severe diarrhoea. All side effects disappeared after discontinuation of the drug. Of course, lengthy prospective trials with a greater number of patients are required to determine the ultimate place of methotrexate in the treatment of patients with severe recalcitrant rheumatoid arthritis. To compare the efficacy and the safety of methotrexate and azathioprine in the treatment of refractory RA, we started a double-blind trial.

\section{Acknowledgment}

We wish to thank Mrs. Marion Janssen for her excellent secretarial help.

\section{REFERENCES}

1. Gubner R, August S, Ginsberg V. (1951) Therapeutic suppression of tissue reactivity. 11. Effect of aminopterin in theumatoid arthritis and psoriasis. Am J Med Sci 1951; 221: 176-182.

2. Groff GD, Shenberger KN, Wilke WS, Taylor TH. Low doses oral methotrexate in rheumatoid arthritis: an uncontrolled trial and review of the literature. Semin Arthritis Rheum 1983; 12: 333-34.

3. Hoffmeister RT. Methotrexate therapy in rheumatoid arthritis: 15 years experience. Am J Med 1983; 75: 69-73.

4. Wilkens RF. Reappraisal of the use of methotrexate in rheumatic disease. Am J Med 1983; 74: 19-25.

5. Andersen PA, West SG, O'Dell JR, Via CS, Claypool RG, Kotzin BL. Weekly pulse methotrexate in rheumatoid arthritis: clinical and immunologic effects in randomized double-blind study. Ann Intern Med 1985; 103: 489-496.

6. Thompson RN, Waits C, Edelman J, Esdaille J, Russell AS. A controlled two centre trial of parenteral methotrexate therapy for refractory rheumatoid arthritis. J Rheumatol 1984; 11: 760-763.

7. Weinblatt ME. Coblyn JS, Fox DA, Fraser PA, Holdsworth DE, Glass DN, Trentheim DE. Efficacy of low-dose methotrexate in rheumatoid arthritis. N Engl J Med 1985; 312: 818-822.

8. Williams HJ, Willkens RF, Samuelson CO, Alarcón GS, Guttadauria M, Yarboro C, Polisson RP, Weiner SR, Luggen ME, Billingsley LH, Dahl SL, Egger MJ, Reading JC, Ward JR. Comparison of low-dose oral pulse methotrexate and placebo in the treatment of rheumatoid arthritis. Arthritis Rheum 1985; 28: $721-729$.

9. Mulder de PHM, van de Putte LBA, Gribnau FWJ. Cytotoxische farmaca bij de behandeling van reumatoide arthritis. Ned Tijdschr Geneeskd 1980; 124: 2126-31.

10. Boerbooms AMTh. Behandeling van reumatoide arthritis. In: Klinische immunologische aspekten van reumatische ziekten. Kater L, red Pfizer 1983: 81-84.

11. Boerbooms AMTh. Methotrexate and theumatoid arthritis. Clin Rheumatol 1985; 4: 387 . 388. 
12. Ropes MW, Bennet GA, Cobb S, Jocox R, Jesser RA. Diagnostic criteria for rheumatoid arthritis: 1958 revision. Ann Rheum Dis 1959; 18: 49-53.

13. Ritchie DM, Boyle JA, McInnes JN, Greieveson P, Buchanan W. Clinical studies with an articular index for assessment of joint tenderness in patients with rheumatoid arthritis. Q J Med 1968; 37: 393-397.

14. Steinbrocker $\mathrm{O}$, Traeger $\mathrm{CH}$, Batteman RC. Therapeutic criteria in rheumatoid arthritis. JAMA 1949; 140: 659-662.

15. Zubler RH, Lange G, Lambert PH, Mieschier PA. Detection of immune complexes in unheated sera by a modified ${ }^{125} \mathrm{~J}-\mathrm{C} 1 \mathrm{q}$ binding test. J Immunol 1976; 116: 262-235.

16. Mancini $G$, Carbonara $A D$, Heremans JF. Immunoquantification of antigens by single radial immunodiffusion. Immunochemistry 1965; 2: 235-254.

17. Speerstra F, Reekers P, van de Putte LBA, Vandenbroucke JP, Rasker JJ, de Rooij DJRAM. HLA-DR antigens and proteinuria induced by aurothioglucose and D-penicillamine in patients with rheumatoid arthritis. J Rheumatol 1983; 10: 948-953.

18. Handy H, McKendry JR, Mierins E, Liver JA. Low-dose methotrexate compared with azathioprine in the treatment of rheumatoid arthritis. Arthritis Rheum 1987; 30: 361-368.

19. Gispen JG, Alarcon GS, Johnson JJ, Acton RT, Barger BO, Koopman W. Toxicity to methotrexate in rheumatoid arthritis. J Rheumatol 1987; 14: 74-79.

20. Roenigk HH Jr, Auerbach R, Maibach HJ, Weinstein GD. Methotrexate guidelines: revised. J Am Acad Dermatol 1981; 112: 977-981.

21. Sostman HD, Matthay RA, Putman CE, Smith GJW. Methotrexate induced pneumonitis. Medicine 1976; 55: 371-388.

22. Carson CW, Cannon GW, Egger MJ, Ward JR, Clegg DO. Pulmonary disease during the treatment of rheumatoid arthritis with low-dose pulse methotrexate. Semin Arthritis Rheum 1987; 16: 187-195.

23. St.Clair EW, Rice JK, Snyderman R. Pneumonitis complicating low-dose methotrexate therapy in rheumatoid arthritis. Arch Intern Med 1985; 145: 2035-2038.

24. Weinstein HD, Frost P. Methotrexate for psoriasis: a new therapeutic schedule. Arch Dermatol 1971; 103: 33-38. 
Chapter 6

\section{METHOTREXATE VERSUS AZATHIOPRINE \\ IN THE TREATMENT OF RHEUMATOID ARTHRITIS. \\ A FORTY-EIGHT-WEEK RANDOMIZED, DOUBLE-BLIND TRIAL}

Maurice E.C. Jeurissen ${ }^{1}$, Agnes M.Th. Boerbooms', Levinus B.A. van de Putte', Wim H. Doesburg ${ }^{2}$, Jan Mulder', Johannes J. Rasker ${ }^{3}$, Marijn W.M. Kruijsen ${ }^{3}$, Joost F. Haverman', Henk J. van Beusekom ${ }^{3}$, Wim Hissink Muller', Marcel J.A.M. Franssen", and Dirk-Jan R.A.M. de Rooy ${ }^{6}$

Department of Rheumatology ${ }^{1}$, University Hospital Nijmegen, Department of Statistical Consultation ${ }^{2}$, University Hospital Nijmegen, The Netherlands.

Departments of Rheumatology, Medisch Spectrum Twente Enschede ${ }^{3}$, Bosch Medicentrum 's Hertogenbosch", Maria and Elisabeth Hospital Tilburg', St Maartenskliniek Nijmegen ${ }^{6}$.

Arthritis Rheum 1991; 34: 761-772 (Reproduced with permission) 



\section{I ABSTRACT}

We conducted a double-blind, randomized trial comparing azathioprine (AZA) and methotrexate (MTX) in the treatment of patients with rheumatoid arthritis in whom parenteral gold and/or D-penicillamine treatment had been unsuccessful. Patients were randomly assigned to receive either AZA (100 mg daily) or oral MTX (7.5 mg weekly). After 8 weeks, the dosage was increased depending on the clinical improvement. Sixtyfour patients were followed up for 48 weeks (33 AZA, 31 MTX). Comparison of values at week 24 with baseline values revealed significant improvement in 12 of 13 disease variables in the MTX group and in 6 of 13 in the AZA group. Comparison between the 2 treatment groups at 24 weeks, by area-under-the-curve analysis, showed significantly more improvement in the MTX group in terms of the swollen joint count, pain score, erythrocyte sedimentation rate, C-reactive protein level, hemoglobin level, thrombocyte level, and disease activity score. A significant overall clinical improvement (disease activity score) was found in 7 of 20 patients treated with AZA and 18 of 30 patients treated with MTX after 24 weeks of therapy, and in 6 of 12 AZA-treated patients and 19 of 25 MTX-treated patients after 48 weeks. The number of withdrawals due to side effects was significantly higher in the AZA group. After 48 weeks, only 12 patients from the AZA group (36\%), but 25 from the MTX group (81\%), were still using the initial drug. These results demonstrate MTX to be superior to AZA in the treatment of rheumatoid arthritis, with a more rapid clinical improvement which is sustained after 1 year, accompanied by a lower rate of serious adverse reactions.

\subsection{INTRODUCTION}

The role of cytoloxic drugs, especially low-dose methotrexate (MTX; 7.5-15 mg weekly), in the treatment of rheumatoid arthritis (RA) is currently the subject of much debate (1-3). Since immune mechanisms are considered to play a crucial role in the pathogenesis of RA, immunosuppressive, cytotoxic drugs have been used in RA for many years, but almost exclusively in disease that has already been demonstrated to be refractory to other disease-modifying antirheumatic drugs. Until recently, most rheumatologists in Western Europe have used azathioprine (AZA) or, less often, cyclophosphamide, to treat RA patients in whom parenteral gold and/or D-penicillamine (DP) have been ineffective and/or have produced side effects (4). In an open study, we have demonstrated the clinical efficacy of MTX for patients whose RA had failed to respond to, or who had unacceptable side effects from, hydroxychloroquine, aurothioglucose, DP, and AZA (5). Many controlled trials have compared AZA with other second-line drugs in the treatment of RA at all stages, and have not demonstrated superiority of AZA (6-11). In RA patients not previously treated with second-line drugs, low-dose MTX was found to act earlier than parenteral gold, but its efficacy was similar to that of the gold $(12,13)$. Studies of the value of MTX treatment in advanced RA that has been unresponsive to parenteral gold and/or DP have consisted of placebo-controlled trials (14-17) and longterm, open prospective trials (18-21). 
To date, 2 short-term, double-blind studies comparing AZA with MTX in the treatment of RA have been reported ( 1 in abstract form) $(22,23)$. No statistically significant differences were found between the 2 drugs, but there was a trend toward more efficacy in the MTX group. The number of patients in these studies, however, was small. To obtain more data about the role of MTX in the treatment of RA patients who have experienced side effects or lack of efficacy with parenteral gold and/or DP, we conducted a doubleblind trial comparing AZA and MTX, focusing on the efficacy and toxicity of both drugs. Influences on serologic and immunologic parameters were also evaluated.

\subsection{PATIENTS AND METHODS}

Patients. To participate in the trial, patients were required to meet the following criteria: 1) active classic or definite rheumatoid arthritis according to the 1958 criteria of the American Rheumatism Association (ARA) (24) (patients also fulfilled the 1987 revised ARA criteria for RA (25); 2) active disease defined by the presence of $\geq 3$ swollen joints, $\geq 6$ joints that were painful or tender on motion, erythrocyte sedimentation rate (ESR) $\geq 28 \mathrm{~mm} /$ hour, and moming stiffness of $\geq 45$ minutes (at least 3 of these 4 features had to be present); 3) age between 16 and 75 years; and 4) unsuccessful treatment with parenteral gold, DP, or both (lack of efficacy after a minimum treatment period of 6 months or development of unacceptable adverse effects). Exclusion criteria consisted of 1) previous therapy with AZA or MTX; 2) childbearing potential; 3) functional class IV according to the Steinbrocker criteria $(26)$; 4) acute or chronic infection (e.g., pyelitis, tuberculosis); 5) obesity (>15 kg above ideal body weight); 6) liver function abnormality, defined as the result of any liver function test exceeding twice the normal value, or presence of a known liver disease; 7) renal disease, defined by a serum creatinine level $>130 \mu$ moles/liter and/or a creatinine clearance rate of $<50$ $\mathrm{ml} /$ minute as estimated according to the method of Cockcroft and Gault (27); 8) hematologic abnormality e.g., leukocyte count $<3.5 \times 10^{9} /$ liter or platelet count $<150 \times$ $10^{\circ} /$ liter; 9) malignancy; 10) insulin-dependent diabetes mellitus; 11) alcoholism or alcohol abuse (>4 oz/day); 12) use of other antifolate drugs (such as sulfonamide derivatives) or allopurinol; 13) active peptic ulcer disease; 14) history of poor compliance with medication regimens.

Study design. Sixty-four eligible patients from 5 different clinics were enrolled in the trial, during the period November 1986 through November 1988. The protocol was approved by each institution's ethics committee, and each patient gave informed consent prior to study entry. Medical treatment and clinical evaluation of all patients was performed by the same rheumatologist (MECJ). All clinical evaluations were performed at roughly the same time of the day. Other second-line-drugs were discontinued at least 4 weeks before study entry.

The first phase of the study was a double-blind, parallel trial of 24 weeks duration. Patients who showed good response were continued in the double-blind trial until the forty-eighth week. Those who were partial or poor responders began an open phase of treatment, also until the forty-eighth week. Patients were randomly allocated to either the 
MTX group or the AZA group in blocks of 6 patients, stratified for functional class II or III. All patients were followed up on an outpatient basis as much as possible. Seven of the 64 patients were hospital inpatients at the start of their therapy.

As in other studies $(10,12,16,17)$ good (or marked) improvement of a disease variable was defined as $\geq 50 \%$ improvement over the initial value, partial (or moderate) response as $30-49 \%$ improvement, lack of response (stable condition) as 0-29\% improvement, and worsening if the final values were worse than the initial values. We used a definition of "overall" clinical improvement that was based on the following parameters, similar to those used to define active RA in the study inclusion criteria: 1) patient's pain assessment, using a $100-\mathrm{mm}$ visual analog scale (VAS; $0 \mathrm{~mm}=$ no pain and $100 \mathrm{~mm}=$ very severe pain); 2) Ritchie articular index (28); 3) ESR; 4) moming stiffness. Good overall improvement was defined as $\geq 50 \%$ improvement in at least 3 of these 4 disease variables, partial (moderate) improvement as 30-49\% improvement in at least 2 of the 4 variables (and no worsening in the other variables), stable disease as 0-29\% improvement in the 4 disease variables, and worsening as deterioration in the variables compared with baseline values.

In patients who had less than moderate overall improvement 8 weeks after start of the trial, the dosage of the study drug was increased. Depending on a patient's overall clinical improvement at 24 weeks, it was decided whether the double-blind procedure should be continued. The study drug was withdrawn in patients with no effect, worsening, or serious adverse reactions. Patients in whom the initial study drug was withdrawn received the alternative drug in an open phase (i.e., AZA instead of MTX, and vice versa), unless there were contraindications. In order to assess disease activity in one composite score without the need of correction for multiple statistical testing, we used the previously validated disease activity score (DAS), which includes the variables Ritchie articular index, number of swollen joints, ESR, and general health (by VAS) $(29,30)$. To measure patient compliance, remaining pills were counted every 2 months.

Medication regimens. Using a double-dummy technique, all patients were initially given the normal dosage of the study drug, i.e., either 2 daily tablets each containing 50 mg AZA with 3 weekly placebo capsules resembling MTX (in 3 divided doses every 12 hours) or 3 weekly capsules each containing $2.5 \mathrm{mg}$ MTX with 2 daily placebo tablets resembling AZA. Depending on the clinical effect after 8 weeks, the dosage was increased to either $150 \mathrm{mg}$ AZA daily with $6 \mathrm{MTX}$ placebo capsules weekly or $15 \mathrm{mg}$ MTX weekly with $3 \mathrm{AZA}$ placebo tablets daily. If toxicity occurred, trial medication could be temporarily reduced to $50 \mathrm{mg} \mathrm{AZA/day} \mathrm{or} 5 \mathrm{mg} \mathrm{MTX/week.}$

The dosages of nonsteroidal anti-inflammatory drugs (NSAIDs) and prednisone ( $\leq 10$ mg daily) were kept stable for at least 4 weeks before study entry. Patients were instructed not to change the dosage of any medication throughout the study. Intra-articular corticosteroid injections were administered only in rare instances. Injected joints and joints on which surgery had been performed were excluded from all assessments.

Clinical assessment. Eight clinical variables were assessed monthly during the first 6 months and every 2 months thereafter, until the forty-eighth week. These were (a) 
Ritchie articular index (possible range 0-78); (b) number of swollen joints (possible range 0-46); (c) number of tender joints (possible range 0-53); (d) patient's assessment of pain, using a 100-mm VAS (possible range 0-100); (e) patient's general health assessment, using a VAS; (f) morning stiffness; (g) grip strength, using a sphygmomanometer (Tonometer, von Recklinghausen, FRG) (possible range $0-300 \mathrm{~mm} \mathrm{Hg}$; the mean value of 3 measurements of each hand was recorded); (h) functional class according, to the Steinbrocker criteria.

Adverse reactions and withdrawals from the study. At each visit, patients were routinely questioned about symptoms possibly related to AZA or MTX toxicity. Minor to moderate toxicity (e.g., gastrointestinal [GI] symptoms, stomatitis) sometimes required dosage adjustment or temporary discontinuation (1-3 weeks) of trial medication. Trial medication was temporarily withheld if the leukocyte count decreased to $<3.5 \times 10^{\circ} /$ liter or the platelet count to $<150 \times 10^{9} /$ liter, if the serum creatinine level rose to $>130$ $\mu$ moles/liter, or if liver enzyme levels exceeded twice the upper limit of normal. Patients were permanently withdrawn from the initial treatment if they experienced severe adverse reactions or if their clinical condition deteriorated to such an extent as to necessitate other therapy. Permanent withdrawal also occurred if patients failed to take trial medication or to keep scheduled clinic appointments.

Laboratory assessment. During the first month of treatment, hemoglobin (Hgb) levels and leukocyte (and differential count) and platelet counts were measured weekly, and kidney and liver function were assessed (by measurement of serum creatinine levels, and gamma glutamyl transferase (GGT) levels, alkaline phosphatase, serum aspartate aminotransferase (AST), and serum alanine aminotransferase (ALT) respectively) every 2 weeks. Thereafter, these values were obtained every 4 weeks. The following laboratory variables were measured every 4 weeks from the initiation of treatment: ESR (Westergren), C-reactive protein (CRP), mean corpuscular volume. The estimated creatinine clearance rate was calculated at baseline and at 24 weeks and 48 weeks. Urinalysis, measurement of total serum protein and serum protein electrophoresis, and testing for serum IgA, IgG, IgM, antinuclear antibody, rheumatoid factor (RF; by the latex fixation and Rose-Waaler methods), C3, and C4 were performed every 8 weeks. Patients were regarded as $R F$ positive if the latex fixation titer was $\geq 1: 80$ and/or the Rose-Waaler titer was $\geq 1: 64$. Tissue typing for HLA-A, B, and D phenotypes was performed using standardized sera from the 8th and 9th International Histocompatibility Workshops. To obtain uniformity in testing methods and laboratory units used with patients from the 5 cooperating clinics, all laboratory tests were performed at University Hospital, Nijmegen, except for ESR, blood cell counts, and kidney and liver function tests.

Statistical analysis. Because patients were randomly assigned to the 2 treatment groups, there was only a $5 \%$ chance of statistically significant differences occurring in baseline variables. Nevertheless, we investigated the validity of the treatment group allocation procedure, using standard statistical tests. The differences in baseline and demographic characteristics were assessed using the chi-square test for nominal variables and Student's 
2-tailed test for other variables, such as age and duration of RA.

After 24 weeks of treatment, all clinical data were analyzed using 2 different approaches. First, the degree of change from baseline to week 24 values was compared between the 2 treatment groups, using a Student's 2-tailed test for those patients who completed 24 weeks of treatment with the originally assigned drug. We also performed an intent-to-treat analysis, whereby all patients who were initially randomized to receive either AZA or MTX were assessed at the twenty-fourth and forty-eighth weeks regardless of whether they had withdrawn from the original drug and switched to another secondline drug. Second, the area-under-the-curve (AUC) was calculated, to utilize all data at each 4-week interval during the first 24 weeks. For this analysis, a relative value is used [AUC/(baseline $x$ 24)]. The relative AUC was compared between the 2 groups, using both an intent-to-treat approach and an approach that included only patients who continued taking the same drug throughout the 24 weeks. Moreover, in the AZA group, a comparison was made between patients who withdrew $(n=13)$ and patients who continued to take AZA for 24 weeks $(n=20)$.

All efficacy results are presented as mean differences from baseline. Ninety-five percent confidence intervals were calculated. An improvement of the DAS by $\geq 1.08$ was considered statistically significant (29). All randomized patients were included in the safety analysis.

\subsection{RESULTS}

Patient characteristics. Of the 64 patients enrolled in the study, 33 were randomized to receive AZA and 31 to receive MTX. There were no significant differences between the 2 treatment groups in any demographic or clinical variables at study entry, except that the MTX group had a higher proportion of women $(P<0.01)$ (Table 1) and the AZA group had a higher proportion of patients who were taking prednisone $(P=0.04)$. No significant differences in disease variables (number of swollen joints, Ritchie articular index, pain score, duration of morning stiffness, ESR) were found between AZA patients who were and those who were not taking prednisone at entry into the study. These disease variables also did not differ significantly between female and male patients in the AZA group at study entry. Previous therapy with other second-line drugs was comparable between the 2 groups (Table 1). The duration of RA was comparable in the 2 groups (7 patients in the AZA group and 7 in the MTX group had relatively early disease [defined arbitrarily as 1.5-4.5 years], 11 in the AZA group and 9 in the MTX group had disease duration of 4.5-9 years, and 15 in the AZA group and 15 in the MTX group had disease of $>9$ years duration).

Efficacy in patients who received the same drug for 24 weeks and for 48 weeks. Since only patients who completed at least 24 weeks of the same drug were included in the analysis of the efficacy of AZA versus MTX, 50 patients (20 AZA, 30 MTX) were eligible for this analysis. Thirteen patients in the AZA group permanently stopped taking the trial medication within the first 3 months because of severe side effects. One MTX patient was withdrawn before week 24 because of noncompliance. In this patient, MTX 
Table 1. Patient characteristics at baseline, by treatment group *

\begin{tabular}{|c|c|c|}
\hline Variable & $\begin{array}{l}\text { Azathioprine } \\
\text { group } \\
(\mathrm{n}=33)\end{array}$ & $\begin{array}{l}\text { Methotrexate } \\
\text { group } \\
(n=31)\end{array}$ \\
\hline \multicolumn{3}{|l|}{ Age (years) } \\
\hline Mean $\pm S D$ & $55.8 \pm 9.3$ & $57.3 \pm 9.5$ \\
\hline Range & $34-71$ & $38-71$ \\
\hline \multicolumn{3}{|l|}{ Disease duration (years) } \\
\hline Mean $\pm S D$ & $9.4 \pm 5.6$ & $12.8 \pm 10.0$ \\
\hline Range & $1.5-26.5$ & $1.5-40$ \\
\hline Female/males & $17 / 16$ & $26 / 5$ \\
\hline $\begin{array}{l}\text { Steinbrocker functional } \\
\text { class II/III }\end{array}$ & $26 / 7$ & $25 / 6$ \\
\hline HLA-DR4 positive & 22 & 19 \\
\hline $\begin{array}{l}\text { Rheumatoid factor positive } \\
\text { (latex fixation titer } \geq 1: 80 \text { ) }\end{array}$ & 33 & 29 \\
\hline Subcutaneous nodules & 11 & 11 \\
\hline Joint prosthesis & 7 & 7 \\
\hline \multicolumn{3}{|l|}{ Previous second-line drugs } \\
\hline Aurothioglucose & $33(100)$ & $30(97)$ \\
\hline D-penicillamine & $23(70)$ & $25(81)$ \\
\hline Hydroxychloroquine & $26(79)$ & $25(81)$ \\
\hline Sulfasalazine & $8(24)$ & $7(23)$ \\
\hline Auranofin & $4(12)$ & $2(6)$ \\
\hline
\end{tabular}

* Unless otherwise indicated, values are the number of patients; values in parentheses are percentages.

\# $\mathrm{P}=0.01$

was resumed in an open phase 5 weeks later.

When week 24 values were compared with baseline values within each treatment group (Table 2), the MTX group had significant improvement in more clinical and laboratory variables than did the AZA group (12 of 13 versus 6 of 13). After 48 weeks of treatment with the same drug, 13 of 13 variables had improved significantly from baseline in the MTX group, compared with 10 of 13 in the AZA group. At both 24 weeks and 48 weeks, improvement was consistently more pronounced in the MTX group than in the AZA group for nearly all efficacy measures. After 24 weeks, the difference in improvement between the AZA-treated patients and the MTX-treated patients was significant for the swollen joint count, ESR, and $\mathrm{Hgb}(\mathrm{P}<0.02)$ (Table 2).

Figure 1 shows the mean values for 5 clinical and laboratory variables as measured at each 4-week interval up to week 24 , in both treatment groups. In order to use these findings from each 4-week assessment, an AUC analysis for weeks 0-24 was performed (Table 3). This analysis showed significantly greater improvement in the number of swol- 
Table 2. Clinical and laboratory variables: mean \pm SD values at baseline and changes from baseline after 24 weeks and 48 weeks of treatment with the same drug

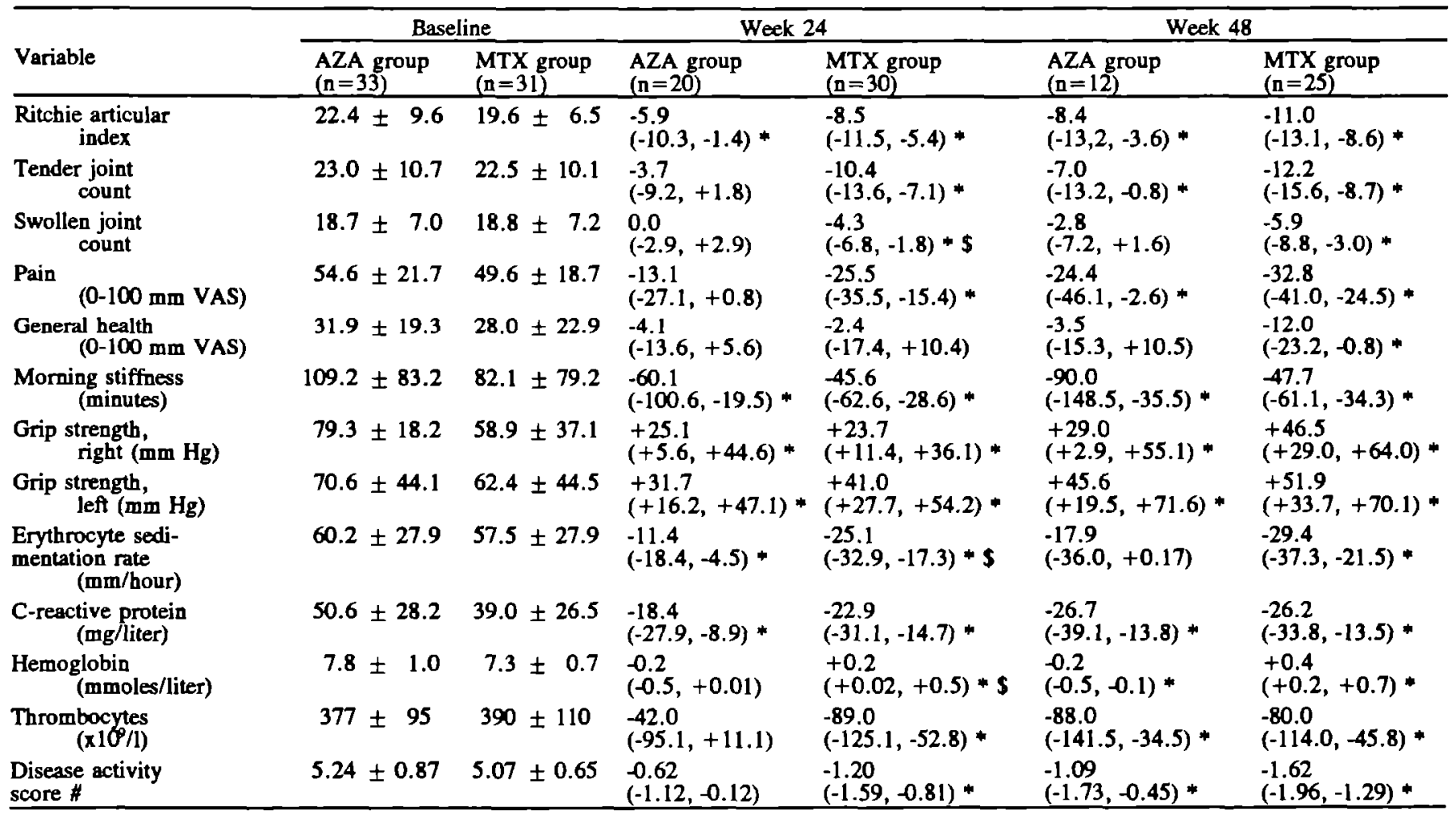

Values in parentheses are $95 \%$ confidence intervals. AZA = azathioprine; MTX = methotrexate; VAS = visual analog scale Significant change from baseline

Significant difference from the AZA group $(P<0.02)$

\# See Patients and Methods for description of the disease activity score. An improvement of $\geq 1.08$ is significant 
Table 3. Relative area-under-the-curve (AUC) between week 0 and week 24 , by intention-to-treat analysis (IT) and by analysis of patients who continued the same treatment for the 24 weeks (same) *

\begin{tabular}{|c|c|c|c|c|c|c|}
\hline \multirow[b]{2}{*}{ Variable } & \multicolumn{2}{|c|}{ AZA group } & \multicolumn{2}{|c|}{ MTX group } & \multicolumn{2}{|c|}{$\begin{array}{l}\text { P, AZA } \\
\text { vs MTX }\end{array}$} \\
\hline & $\begin{array}{c}\text { IT } \\
(n=33)\end{array}$ & $\begin{array}{c}\text { Same } \\
(n=20)\end{array}$ & $\begin{array}{c}\mathrm{IT} \\
(\mathrm{n}=31)\end{array}$ & $\begin{array}{c}\text { Same } \\
(n=30)\end{array}$ & IT & Same \\
\hline $\begin{array}{l}\text { Ritchie articular } \\
\text { index }\end{array}$ & $\begin{array}{l}0.81 \\
(0.71,0.90)\end{array}$ & $\begin{array}{l}0.82 \\
(0.67,0.96)\end{array}$ & $\begin{array}{l}0.74 \\
(0.65,0.82)\end{array}$ & $\begin{array}{l}0.74 \\
\quad(0.65,0.82)\end{array}$ & 0.08 & 0.07 \\
\hline $\begin{array}{l}\text { Tender joint } \\
\text { count }\end{array}$ & $\begin{array}{l}0.89 \\
(0.74,1.04)\end{array}$ & $\begin{array}{l}0.95 \\
(0.72,1.18)\end{array}$ & $\begin{array}{l}0.73 \\
(0.65,0.81)\end{array}$ & $\#$ & 0.17 & 0.12 \\
\hline $\begin{array}{l}\text { Swollen joint } \\
\text { count }\end{array}$ & $\begin{array}{l}1.03 \\
(0.94,1.12)\end{array}$ & $\begin{array}{l}1.08 \\
(0.95,1.21)\end{array}$ & $\begin{array}{l}0.94 \\
(0.85,1.02)\end{array}$ & $\#$ & 0.10 & 0.02 \\
\hline Pain (VAS) & $\begin{array}{l}0.87 \\
(0.72,1.01)\end{array}$ & $\begin{array}{l}0.93 \\
(0.70,1.15)\end{array}$ & $\begin{array}{l}0.66 \\
(0.54,0.77)\end{array}$ & $\#$ & 0.04 & 0.03 \\
\hline Morning stiffness & $\begin{array}{l}0.65 \\
(0.51,0.78)\end{array}$ & $\begin{array}{l}0.68 \\
(0.49,0.86)\end{array}$ & $\begin{array}{l}0.68 \\
(0.56,0.79)\end{array}$ & $\#$ & 0.95 & 0.97 \\
\hline $\begin{array}{l}\text { Grip strength, } \\
\text { right }\end{array}$ & $\begin{array}{l}1.25 \\
(1.09,1.41)\end{array}$ & $\begin{array}{l}1.23 \\
(1.00,1.46)\end{array}$ & $\begin{array}{l}1.64 \\
(1.21,2.06)\end{array}$ & $\#$ & 0.22 & 0.18 \\
\hline $\begin{array}{l}\text { Grip strength, } \\
\text { left }\end{array}$ & $\begin{array}{l}1.41 \\
(1.19,1.62)\end{array}$ & $\begin{array}{l}1.48 \\
(1.15,1.80)\end{array}$ & $\begin{array}{l}2.02 \\
(1.41,2.62)\end{array}$ & $\#$ & 0.15 & 0.35 \\
\hline $\begin{array}{l}\text { Erylhrocyte sedi- } \\
\text { mentation rate }\end{array}$ & $\begin{array}{l}0.86 \\
(0.77,0.95)\end{array}$ & $\begin{array}{l}0.72 \\
(0.63,0.80)\end{array}$ & $\begin{array}{l}0.67 \\
(0.60,0.73)\end{array}$ & $\#$ & 0.002 & 0.009 \\
\hline $\begin{array}{l}\text { C-reactive } \\
\text { protein }\end{array}$ & $\begin{array}{l}0.74 \\
(0.62,0.86)\end{array}$ & $\begin{array}{l}0.75 \\
(0.58,0.91)\end{array}$ & $\begin{array}{l}0.42 \\
(0.30,0.53)\end{array}$ & $\#$ & 0.002 & 0.004 \\
\hline Hemoglobin & $\begin{array}{l}0.96 \\
(0.94,0.98)\end{array}$ & $\begin{array}{l}0.95 \\
(0.93,1.02)\end{array}$ & $\begin{array}{l}1.00 \\
(0.98,1.02)\end{array}$ & $\#$ & 0.01 & 0.01 \\
\hline Thrombocytes & $\begin{array}{l}0.96 \\
(0.88,1.03)\end{array}$ & $\begin{array}{l}0.99 \\
(0.86,1.11)\end{array}$ & $\begin{array}{l}0.85 \\
(0.81,0.89)\end{array}$ & $\#$ & 0.004 & 0.003 \\
\hline $\begin{array}{l}\text { Disease activity } \\
\text { score }\end{array}$ & $\begin{array}{l}0.93 \\
(0.88,0.97)\end{array}$ & $\begin{array}{l}0.94 \\
(0.88,0.99)\end{array}$ & $\begin{array}{l}0.86 \\
(0.83,0.90)\end{array}$ & $\#$ & 0.03 & 0.02 \\
\hline
\end{tabular}

- Values in parentheses are $95 \%$ confidence intervals. AZA = azathioprine;

MTX = methotrexate;

VAS $=$ visual analog scale.

\# Equal results as in IT.

len joints, pain score, ESR, CRP level, thrombocyte count, Hgb level, and DAS in the MTX group, compared with the AZA group.

Efficacy as assessed by intention-to-treat analysis at weeks 24 and 48 . To assess the final outcome of all patients who entered the study, an intention-to-treat analysis was performed. Twenty-four weeks after initiation of the study, the 31 patients originally allocated to the MTX group showed significantly more improvement in the pain score, 
Table 4. Number of patients with good ( $\geq 50 \%$ ) improvement, partial (30-49\%) improvement, stable condition (0-29\% improvement), or worsening in clinical and laboratory variables, after 24 weeks of treatment with the same drug, by treatment group

\begin{tabular}{lccccc}
\hline & \multicolumn{2}{c}{$\begin{array}{c}\text { Azathioprine group } \\
(\mathrm{n}=20)\end{array}$} & & \multicolumn{2}{c}{$\begin{array}{c}\text { Methotrexate group } \\
(\mathrm{n}=30)\end{array}$} \\
\cline { 2 - 3 } \cline { 5 - 6 } Variable & $\begin{array}{c}\text { good/partial } \\
\text { improvement }\end{array}$ & $\begin{array}{c}\text { stable/ } \\
\text { worse }\end{array}$ & $\begin{array}{c}\text { good/partial } \\
\text { improvement }\end{array}$ & $\begin{array}{c}\text { stable/ } \\
\text { worse }\end{array}$ \\
\hline $\begin{array}{l}\text { Ritchie articular } \\
\text { index }\end{array}$ & $9 / 2$ & $4 / 5$ & & $12 / 7$ & $8 / 3$ \\
$\begin{array}{l}\text { Tender joint } \\
\text { count }\end{array}$ & $7 / 1$ & $6 / 6$ & & $15 / 4$ & $10 / 1$ \\
$\begin{array}{l}\text { Swollen joint } \\
\text { count }\end{array}$ & $3 / 1$ & $6 / 10$ & & $5 / 8$ & $10 / 7$ \\
$\begin{array}{l}\text { Pain (visual ana- } \\
\text { log scale) }\end{array}$ & $8 / 2$ & $4 / 6$ & & $17 / 4$ & $4 / 5$ \\
$\begin{array}{l}\text { Morning stiffness } \\
\begin{array}{l}\text { Grip strength, } \\
\text { right }\end{array}\end{array}$ & $9 / 4$ & $4 / 3$ & & $13 / 11$ & $6 / 0$ \\
$\begin{array}{c}\text { Grip strength, } \\
\text { left }\end{array}$ & $4 / 6$ & $5 / 5$ & & $6 / 9$ & $12 / 3$ \\
$\begin{array}{l}\text { Erythrocyte sedi- } \\
\text { mentation rate }\end{array}$ & $6 / 6$ & $5 / 3$ & & $10 / 8$ & $9 / 3$ \\
$\begin{array}{l}\text { C-reactive } \\
\text { protein }\end{array}$ & $3 / 4$ & $11 / 2$ & $15 / 4$ & $10 / 1$ \\
\begin{tabular}{l} 
Thrombocytes \\
\hline
\end{tabular} & $8 / 4$ & $6 / 2$ & $20 / 1$ & $8 / 1$ \\
\hline
\end{tabular}

ESR, CRP level, Hgb level, thrombocyte count, and DAS, compared with the 33 patients assigned to the AZA group, as shown by AUC analysis (Table 3). After 48 weeks, there were no significant differences in the mean values of clinical and laboratory variables compared with baseline (results not shown).

Percentage improvement in disease variables and clinical response. As shown in Table 4, more MTX-treated than AZA-treated patients had good or partial improvement (judged by percentage change) in each individual disease variable after 24 weeks of treatment with the same drug. After 24 weeks of treatment with the same drug, 23 of 30 patients in the MTX group and 12 of 20 in the AZA group had achieved good and/or partial overall improvement (as defined in Patients and Methods). A lack of clinical effect after 24 weeks was found in 4 MTX-treated patients and 8 AZA-treated patients. When the clinical response was assessed according to the composite DAS, 18 of 30 MTX-treated patients (60\%) and 7 of 20 AZA-treated patients (35\%) had improved significantly after 24 weeks of treatment with the same drug. After 48 weeks of treatment with the same drug, 6 of 12 patients in the AZA group (50\%) and 19 of 25 in the MTX group (76\%) had significant improvement in the DAS.

Time to response. In addition to the more pronounced clinical response to MTX, a more 

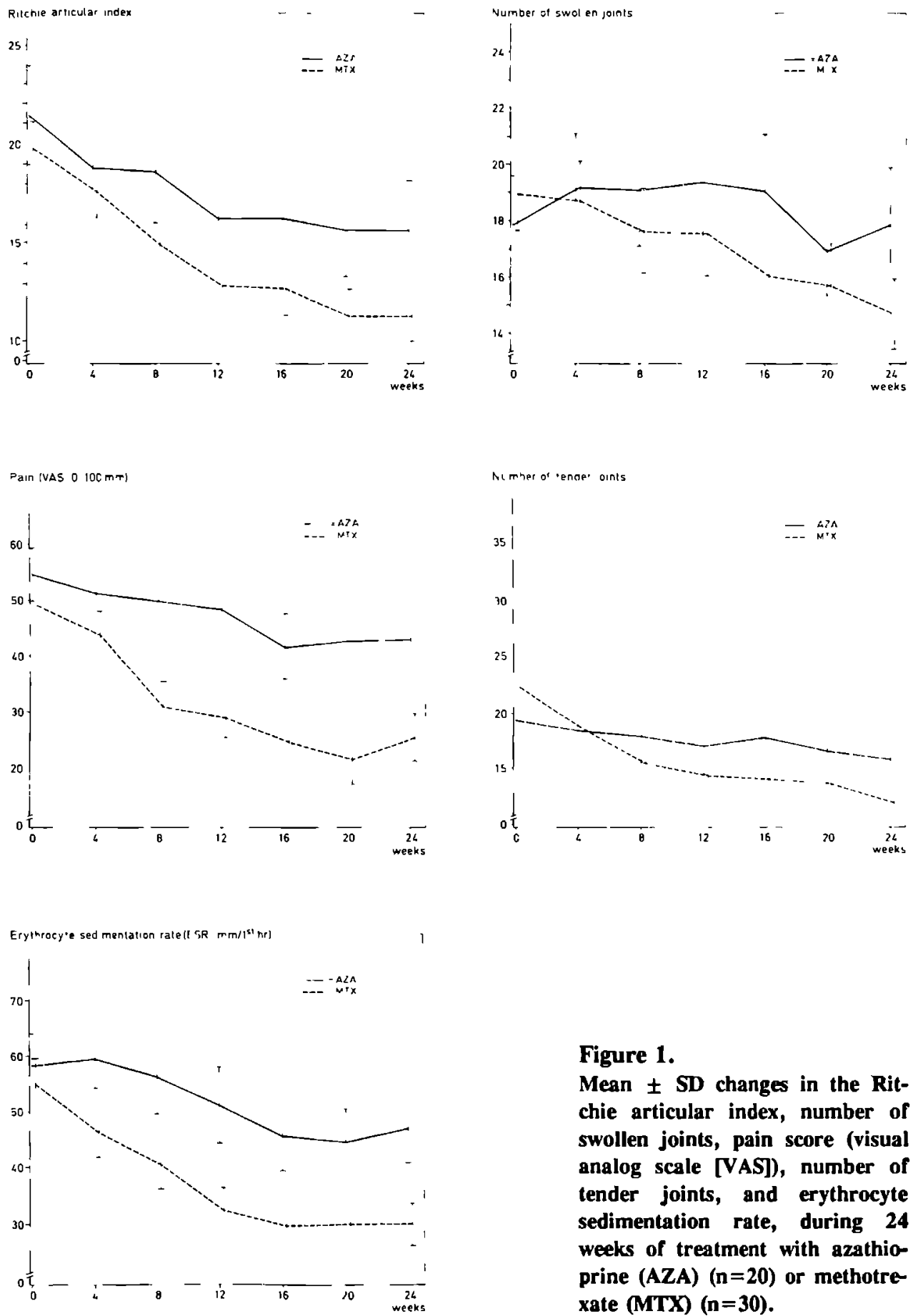

Figure 1.

Mean \pm SD changes in the Ritchie articular index, number of swollen joints, pain score (visual analog scale [VAS]), number of tender joints, and erythrocyte sedimentation rate, during 24 weeks of treatment with azathioprine (AZA) $(n=20)$ or methotrexate (MTX) $(n=30)$. 
rapid and sustained clinical response to MTX was demonstrated. Among those who continued treatment with the same drug, the numbers of patients in the AZA group and the MTX group, respectively, who had significant improvement in the DAS were as follows: 1 and 0 at week 4,1 and 7 at week 8,1 and 8 at week 12,3 and 12 at week 16,5 and 15 at week 20 , and 6 and 18 at week 24 .

Effects on serologic and immunologic variables. Mean baseline values of IgA, IgG, and IgM were above-normal in both treatment groups. After 24 weeks and 48 weeks, there was a 10-25\% decrease in the immunoglobulin levels in both groups (the greatest decrease was in IgA, the smallest in IgG). During therapy, the mean C3 level decreased significantly $(P \leq 0.02)$, to the high end of the normal range, in both groups, whereas $C 4$ levels fell only slightly. The mean RF titer by latex fixation, which was $1: 2,523$ in the AZA group and 1:1,753 in the MTX group at baseline, had decreased by more than $60 \%$ $(P=0.001)$ in both groups after 24 weeks and 48 weeks.

Dosage of the trial medication, and treatment with NSAIDs and corticosteroids. More patients from the AZA group (58\%) than from the MTX group (43\%) needed to have their drug dosage increased after 8 weeks. The number of patients who switched to another second-line drug after discontinuation of the trial drug is shown in Figure 2. The mean \pm SD dosage of AZA for patients who took the drug for up to 24 weeks was 2.06 $\pm 0.67 \mathrm{mg} / \mathrm{kg}$ body weight daily. The mean \pm SD dosage of MTX in that period was $8.80 \pm 2.22 \mathrm{mg}$ weekly. In 3 patients ( $2 \mathrm{AZA} ; 1 \mathrm{MTX}$ ), the dosage of NSAIDs was increased during the trial; the mean corticosteroid dosage did not change in any patient. During the double-blind phase of the study, 5 patients ( $3 \mathrm{AZA} ; 2$ MTX) required a single intra-articular injection of steroid.

Adverse reactions. Table 5 summarizes the adverse reactions that occurred in the 2 treatment groups. The frequency of side effects was similar in both groups. GI reactions were the most frequent side effect of AZA. In 2 of 5 patients who discontinued AZA treatment within the first 10 weeks because of GI side effects, severe vomiting developed after ingestion of only a single tablet. In contrast to the liver enzyme abnormalities found in the MTX group, which were characterized mainly by elevated AST and ALT levels, the liver dysfunction seen in the AZA group was of a cholestatic nature in 3 patients. These liver function abnormalities occurred initially within 2-4 weeks after starting the trial, and again, to a greater extent, after rechallenge with AZA. Levels of alkaline phosphatase and GGT rose to 3-10 times the normal values. In 1 of the AZA-treated patients, liver dysfunction was accompanied by fever and acute dermatitis (31). Hypersensitivity reactions consisting predominantly of fever occurred in 2 other patients (31).

The major side effect of MTX found in this trial was elevation of liver enzyme levels, in $58 \%$ of the patients. The elevation was generally $2-3$ times the normal values; the increase was 5-fold over normal in 1 patient. After temporary discontinuation of the drug or adjustment of the dosage, these values retumed to normal in all patients. In 7 of 9 MTX-treated patients who developed mouth ulcers, elevated liver enzymes were also found, after a mean treatment duration of 8.3 weeks. In 4 patients who started treatment 
Table 5. Adverse reactions and withdrawals during 48 weeks of therapy, by treatment group *

\begin{tabular}{|c|c|c|c|c|}
\hline \multirow[b]{2}{*}{ Reaction } & \multicolumn{2}{|c|}{$\begin{array}{c}\text { Azathioprine group } \\
(\mathrm{n}=33)\end{array}$} & \multicolumn{2}{|c|}{$\begin{array}{l}\text { Methotrexate group } \\
\quad(\mathrm{n}=31)\end{array}$} \\
\hline & reaction & $\begin{array}{l}\text { withdrawal } \\
\text { due } \\
\text { to reaction }\end{array}$ & reaction & $\begin{array}{l}\text { withdrawal } \\
\text { due } \\
\text { to reaction }\end{array}$ \\
\hline \multicolumn{5}{|l|}{ Gastrointestinal } \\
\hline Mouth ulcers & 3 & & 9 & \\
\hline $\begin{array}{l}\text { Nausea, vomiting, } \\
\text { or abdominal pain }\end{array}$ & 18 & 5 & 9 & \\
\hline $\begin{array}{c}\text { Ulcer (gastric/ } \\
\text { duodenal) }\end{array}$ & 3 & & & \\
\hline Diarrhea & 1 & & & \\
\hline $\begin{array}{l}\text { Elevated liver } \\
\text { enzymes }\end{array}$ & 7 & $3 \$$ & 18 & \\
\hline \multicolumn{5}{|l|}{ Hematologic } \\
\hline Leukopenia & 3 & 1 & 1 & \\
\hline $\begin{array}{l}\text { Thrombocytopenia } \\
\text { Pancytopenia }\end{array}$ & 1 & 1 & 3 & \\
\hline Hypersensitivity & & & & \\
\hline Dermatitis & $3 \mathrm{~s}$ & & 2 & 1 \\
\hline $\begin{array}{l}\text { Fever } \\
\text { Other }\end{array}$ & $3 @$ & $3 \mathbf{s}$ & & \\
\hline $\begin{array}{l}\text { Central nervous } \\
\text { system }\end{array}$ & 3 & 1 & 2 & \\
\hline $\begin{array}{l}\text { Nodulosis } \\
\text { Infection }\end{array}$ & 1 & & $\begin{array}{l}1 \\
4\end{array}$ & 1 \\
\hline Total withdrawals & & $13 * *$ & & 2 \\
\hline
\end{tabular}

* Values are the number of patients. Several patients had more than 1 adverse reaction. All withdrawals of azathioprine due to side effects occurred between week 0 and week 12; withdrawals of methotrexate occurred at week 24 .

\# Seven of 9 patients also developed elevated liver enzyme levels after a mean treatment period of 8.3 weeks after development of mouth ulcers.

$\$$ One patient had a triad of fever, dermatitis, and severe liver dysfunction.

(Q) Two of 3 patients also had chills.

** $P=0.03$ versus the methotrexate group.

with AZA but switched to MTX, mouth ulcers also developed during MTX treatment, followed by elevations in liver enzyme levels.

Hematologic side effects leading to permanent withdrawal from the trial occurred in 2 AZA-treated patients: 1 developed pancytopenia (32) and the other developed recurrent leukopenia $\left(2.8 \times 10^{9} / \mathrm{liter}\right)$ and tonsillitis. In $3 \mathrm{MTX}$-treated patients, thrombocytopenia ( $\geq 110 \times 10^{9} /$ liter) developed, but in all 3 cases it disappeared after temporary discontinuation of or lowering the dosage of MTX. Central nervous system symptoms (headache, dizziness) became so troublesome in 1 AZA-treated patient as to necessitate discontinuation of the drug. Development of nodules in uncommon sites was the cause of discontinuation of MTX in 1 patient (33). No increase or decrease of subcutaneous nodules was 


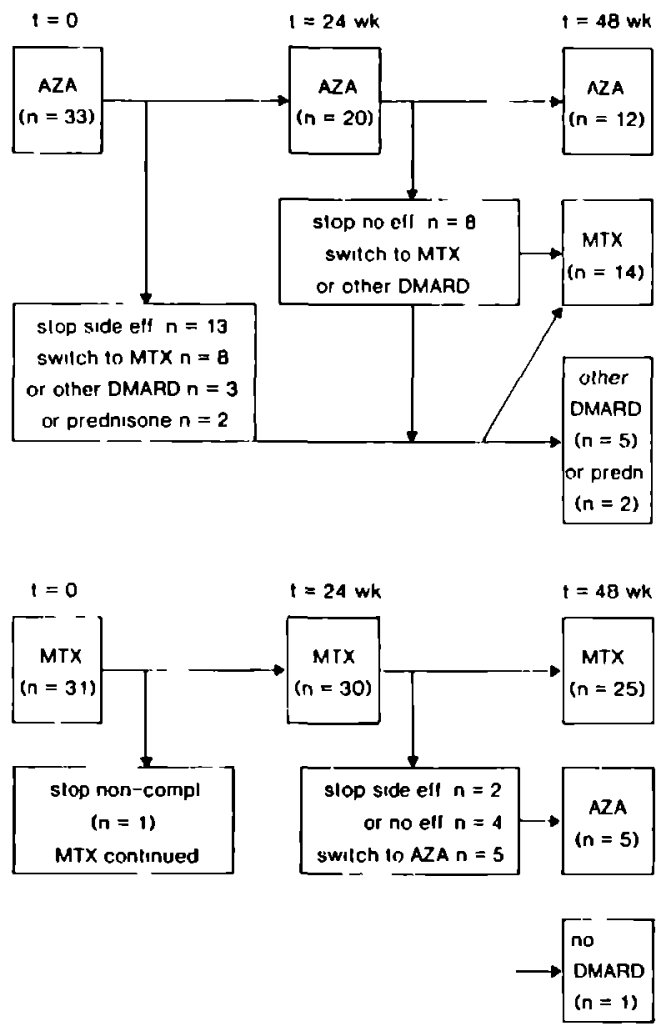

Figure 2.

Course of treatment in patients randomized at baseline $(t=0)$ to receive azalhioprine (AZA) ( $\mathbf{n}=$ 33) or methotrexate (MTX) ( $n=$ 31). The follow-up period was 48 weeks; assessments of treatment course are shown for week 24 (t $=24$ wk) and week $48(t=48$ wk). Stop side eff. = stopped because of side effects; DMARD $=$ disease-modifying antirheumatic drug, such as sulfasalazine or D-penicillamine; stop no eff. = stopped because of lack of effect; predn. = prednisone; stop non-compl. = slopped because of non-compliance.

found in other patients during the follow-up period. Infection developed in 4 MTXtreated patients (pneumonia in 2, sinusitis in 1, pyelitis in 1). MTX was withdrawn for 23 weeks during antibiotic treatment in these patients, then resumed without further complication, including in the patient with pyelitis, who underwent surgery for a large pyelic stone.

\subsection{DISCUSSION}

In the traditional rheumatoid arthritis treatment pyramid, azathioprine is prescribed after parenteral gold and DP (34). The place of methotrexate in this pyramid has not yet been established. Time to clinical response, short- and long-term efficacy, toxicity profile, and long-term safety are important factors in determining the place of a secondline antirheumatic drug. Since AZA $(35,36)$ and MTX $(14-17)$ have already proven to be superior to placebo in the treatment of RA, a comparison with placebo was not included in the present study.

The dosages of AZA and MTX used most frequently in RA range between $1.25 \mathrm{mg} / \mathrm{kg}$ and $2.5 \mathrm{mg} / \mathrm{kg}$ daily $(6-11,35,37)$ and between $7.5 \mathrm{mg}$ and $15 \mathrm{mg}$ weekly $(7-12)$, respec- 
tively. The mean dosages of AZA $(2.06 \mathrm{mg} /$ day) and of MTX $(8.8 \mathrm{mg} /$ week $)$ in this study were in accordance with the dosages used in previous investigations. Following randomization, the 2 treatment groups ( $33 \mathrm{AZA}, 31 \mathrm{MTX}$ ) were comparable with regard to demographic (Table 1), clinical, and laboratory variables (Table 2). The baseline differences between the groups in the female:male ratio and the use of steroid therapy probably did not influence the study results, since baseline disease variables did not differ significantly between patients in the AZA group who were and those who were not receiving prednisone, or between female and male patients in the AZA group. To avoid interobserver variability, all patients were evaluated by the same physician.

Individual clinical and laboratory variables were assessed both in terms of changes from baseline values within each treatment group (Table 2) and in terms of betweengroup differences in the degree of the changes (Tables 2 and 3), after 24 weeks of therapy. It is clear from the data in both Table 2 and Table 3 that MTX was superior to AZA. Although differences in clinical and laboratory variables in the 12 AZA-treated and 25 MTX-treated patients who completed 48 weeks of the same therapy were not significantly different, there was a trend toward more improvement in the MTX group (Table 2). Statistically significant differences between the groups could have been missed because of the low number of patients remaining in the AZA group at 48 weeks.

The area-under-the-curve analysis (Table 3 ) provided additional information, from each 4-week assessment up to week 24. By this analysis, the number of swollen joints, pain score, ESR, CRP level, Hgb level, thrombocyte count, and disease activity score all showed significantly greater improvement in the MTX group compared with the AZA group. Figure 1 shows the course of the disease variables during that period. As recommended by others $(10,12,16,17)$, we also measured the percent improvement in each disease variable after 24 weeks (Table 4). More patients from the MTX group than from the AZA group had good ( $\geq 50 \%$ ) or partial (30-49\%) improvement in individual clinical and laboratory variables. The percentages of MTX-treated patients with good improvement in the tender joint count $(50 \%)$ and in the swollen joint count $(17 \%)$ in our study were comparable with percentages reported by Williams and colleagues (32\% and $21 \%$, respectively) (17) and by Weinblatt and colleagues (54\% and $39 \%$, respectively) (16). The percentages of AZA-treated patients with at least partial improvement in the tender joint count (40\%) and the swollen joint count (20\%) were comparable with percentages reported by Paulus and colleagues (44\% and $38 \%$, respectively) (10).

To assess outcome in all patients who were entered into the study, regardless of whether they completed the protocol, an intent-to-treat analysis was performed. After 24 weeks, there was significantly more improvement in the patient group that was started on MTX $(n=31)$ compared with the group that started on AZA $(n=33)$ (Table 3). After 48 weeks, no significant differences in the individual disease variables were found.

To measure the clinical response to AZA and MTX according to a single parameter, we used the disease activity score $(29,30)$. After 24 weeks and 48 weeks of treatment with the same drug, a higher percentage of MTX-treated patients than AZA-treated patients had significant improvement in the DAS. In the period between week 8 and week 24, 2-3 times more MTX-treated than AZA-treated patients had significant improvement in the DAS. This underscores again the more pronounced and earlier 
response to MTX compared with AZA.

The number of patients who were still taking MTX after 1 year (80\%) is consistent with results from other studies after at least 1 year $(19-22,38)$. The much smaller percentage of patients who were still taking AZA after 1 year $(36 \%)$ is also consistent with other published results (11). The 10-25\% decrease in immunoglobulin levels in both treatment groups, although significant, was somewhat less than was found in our open trial of MTX study treatment (5) and in a placebo-controlled study of MTX treatment (15).

The major adverse reactions noted in this trial (Table 5) were elevated levels of liver enzymes in MTX-treated patients and gastrointestinal complications in AZA-treated patients, which is consistent with earlier reports (38-43). The rate of withdrawal due to side effects of AZA (39\%) was comparable with that occurring in some double-blind studies $(6,23,36)$, but higher than that found in others $(\sim 20 \%)(9,10)$. Adverse reactions to MTX, though common, were mostly mild and transient. A notable observation was the high number of severe liver dysfunction reactions and severe hypersensitivity reactions in AZA-treated patients, most of which developed within 4 weeks (Table 5). Similar findings have been reported previously (23). Severe vomiting after 1 single dose of AZA in 2 patients might also be considered a hypersensitivity reaction (44). We do not have an explanation for the high number of severe adverse reactions to AZA. No differences in HLA tissue type, clinical disease variables, type of NSAID used, or previous adverse reaction to other second-line drugs were found between the patients who withdrew from AZA treatment and those who were able to continue the treatment. To our knowledge, mouth ulcers heralding liver dysfunction after approximately 8 weeks of treatment with MTX, which we found in 7 patients, has not been reported before. In all patients mouth ulcers were mild and alleviated with local therapy. Whether the infections observed in MTX-treated patients were coincidental or were treatment-related is unclear. Both patients with pneumonia (causative agent unknown) were nonsmokers and had no immunoglobulin deficiency. After recovery and reinstitution of MTX, no infections have recurred thus far. A diagnosis of MTX pneumonitis was unlikely, based on the clinical findings, response to antibiotics, and disease course.

The absence of a significant difference in efficacy between AZA and MTX reported by Hamdy et al. (22), in a double-blind study of 42 RA patients, was not confirmed by our results. Patient selection criteria, demographic characteristics, and dosage of trial medication were comparable in their study and ours. Our patients may have had more active disease at baseline, as reflected by higher mean values in the ESR and VAS pain score, and lower grip strength. The disease variables used in the 2 studies were almost identical. In contrast with our results, there was almost no decrease in the ESR in either treatment group in the study by Hamdy et al., whereas the swollen joint count decreased markedly in both groups. Their report gives no data on changes in the $\mathrm{Hgb}$, thrombocyte, or CRP levels. Differences in the number of patients studied (42 versus 64) and in the dropout rate (10\% versus $39 \%$ ) may also be causes for the divergence between our results and those reported by Hamdy and colleagues.

It was difficult to compare our results with those of a second double-blind trial of AZA versus MTX (23), since the findings of that study are presented in abstract form. AZA 
and MTX were shown to have similar efficacy in that short-term (20-week) study of 34 patients. Improvement in grip strength was the only variable for which there was a statistically significant difference between the 2 treatment groups, with greater improvement among those who received MTX. Those authors also found a high percentage of withdrawals due to side effects in the AZA group ( $>40 \%$ ).

In conclusion, this double-blind trial demonstrated superiority of methotrexate to azathioprine in the treatment of $\mathrm{RA}$, as indicated by most of the clinical and laboratory variables individually and by the overall clinical response, after 24 weeks and 48 weeks of therapy. The earlier and more sustained clinical improvement in MTX-treated patients was accompanied by a significantly lower rate of serious adverse reactions. These results suggest that MTX should precede AZA in the treatment pyramid for rheumatoid arthritis.

\section{Acknowledgment}

We are grateful to Marion Janssen and Bianca Schippers for administrative assistance, to J. Benneker, pharmacologist, for her contribution and support to this study, and to the Wellcome Company and the Lederle Company for supplying, respectively, the azathioprine and the methotrexate used in the trial.

Supported by a grant from the Dutch League against Rheumatism.

\section{REFERENCES}

1. Tugwell P, Bennett K, Bell M, Gent M. Methotrexate in theumatoid arthritis: feedback on American College of Physicians guidelines. Ann Intern Med 1989; 110: 581-583.

2. Wilske KR, Healey LA. Remodeling the pyramid: - a concept whose time has come. J Rheumatol 1989; 16: 575-577.

3. Hess EV, Luggen ME. Remodeling the pyramid - a concept whose time has not come. J Rheumatol 1989; 16: 1175-1176.

4. Boerbooms AMTh. Methotrexate and theumatoid arthritis. Clin Rheum 1985; 4: 387-388.

5. Boerbooms AMTh, Jeurissen MEC, Westgeest AAA, Theunisse HAM, Van de Putte LBA. Methotrexate in refractory rheumatoid arthritis. Clin Rheum 1988; 7: 249-256.

6. Currey HLF, Harris J, Mason RM, Woodland J, Beveridge T, Roberts CJ et al. Comparison of azathioprine, cyclophosphamide and gold in the treatment of rheumatoid arthritis. Br Med J 1974; 3: 763-766.

7. Dwosh IL, Stein HB, Urowitz MB, Smythe HA, Hunter T, Ogryzlo MA. Azathioprine in early rheumatoid arthritis: comparison with gold and chloroquine. Arthritis Rheum 1977; 20: 685-692.

8. Levy J, Paulus HE, Bangert R. Comparison of azathioprine and cyclophosphamide in the treatment of rheumatoid arthritis (abstract). Arthritis Rheum 1975; 18: 412-413.

9. Berry H, Liyanage SP, Durance RA, Barnes CG, Berger LA, Evans S. Azathioprine and penicillamine in treatment of rheumatoid arthritis: a controlled trial. Br Med J 1976; 1: 1052-1054.

10. Paulus HE, Williams HJ, Ward JR, Reading JC, Egger MU, Coleman ML et al. Azathioprine versus D-penicillamine in rheumatoid arthritis patients who have been treated unsuccessfully with gold. Arthritis Rheum 1984; 27: 721-727. 
11. Halberg P, Bentzon MW, Crohn O, Gad I. Double-blind trial of levamisole, penicillamine, azathioprine in rheumatoid arthritis. Dan Med Bull 1984; 31: 403-409.

12. Suarez-Almazor ME, Fitzgerald A, Grace M, Russell AS. A randomized controlled trial of parenteral methotrexate compared with sodium aurothiomalate. J Rheumatol 1988; 15: 753-756.

13. Morassut P, Goldstein R, Cyr M, Karosh J, McKendry RJR. Gold sodium thiomalate compared to low-dose methotrexate in the treatment of rheumatoid arthritis: a randomized double-blind 26 week trial. J Rheumatol 1989; 16: 302-306.

14. Thompson RN, Watts C, Edelman J, Esdaile J, Russell AS. A controlled two center trial of parenteral methotrexate for refractory rheumatoid arthritis. J Rheumatol 1984; 11: 760763.

15. Andersen PA, West SG, O'Dell JR, Via CS, Claypool RG, Kotzin BL. Weekly pulse methotrexate in rheumatoid arthritis: clinical and immunological effects in a randomized double-blind study. Ann Intern Med 1985; 203: 489-496.

16. Weinblatt ME, Coblyn JS, Fox DA, Fraser PA, Holdsworth DE, Glass DN et al. Efficacy of low-dose methotrexate in rheumatoid arthritis. N Engl J Med 1985; 312: 818822.

17. Williams HJ, Willkens RF, Samuelson CO Jr, Alarcón GS, Guttadauria M, Yarboro C et al. Comparison of low-dose oral pulse methotrexate and placebo in the treatment of rheumatoid arthritis. Arthritis Rheum 1985; 28: 721-729.

18. Weinblatt ME, Trentham DE, Fraser PA, Holdsworth DE, Falchuk KR et al. Long-term prospective trial of low-dose methotrexate in rheumatoid arthritis. Arthritis Rheum 1988; 31: 167-175.

19. Kremer JM, Lee JK. A long-term prospective study of the use of methotrexate in rheumatoid arthritis: update after a mean of fifty-three months Arthritis Rheum 1988; 31: 577-584.

20. Weinstein A, Marlowe S, Korn J. Low-dose methotrexate of rheumatoid arthritis. Longterm observations. Am J Med 1985; 79: 331-336.

21. Hanrahan PS, Scrivens GA, Russell AS. Prospective long-term follow-up of methotrexate therapy in rheumatoid arthritis: Toxicity, efficacy and radiological progression. $\mathrm{Br} J$ Rheumatol 1989; 28: 147-153.

22. Handy H, McKendry RJR, Mierins E, Liver JA. Low-dose methotrexate compared with azathioprine in the treatment of rheumatoid arthritis: a twenty-four-week controlled trial. Arthritis Rheum 1987; 30: 361-368.

23. Bell M, Chang C-H, Keystone EC, Urowitz MB, Gladman D, Ching C-F. A double-blind randomized controlled trial of azathioprine and methotrexate in the treatment of rheumatoid arthritis (abstract). Arthritis Rheum 1988; 31 (suppl 4): S 114.

24. Ropes MW, Bennett GA, Cobb S, Jacox R, Jessar RA. 1958 Revision of diagnostic criteria for rheumatoid arthritis. Bull Rheum Dis 1958; 9: 175-176.

25. Arnett FC, Edworthy SM, Bloch DA, McShane DJ, Fries JF, Cooper NS et al. The American Rheumatism Association 1987 revised criteria for the classification of rheumatoid arthritis. Arthritis Rheum 1988; 31: 315-324.

26. Steinbrocker O, Traeger $\mathrm{CH}$, Batterman RC. Therapeutic criteria in rheumatoid arthritis. JAMA 1949; 140: 659-662.

27. Cockcroft DW, Gault MH. Prediction of creatinine clearance from serum creatinine. Nephron 1976; 16: $31-41$.

28. Ritchie DM, Boyle JA, McInnes JN, Greieveson P, Buchanan W. Clinical studies with an articular index for assessment of joint tenderness in patients with rheumatoid arthritis. Q $J$ Med 1968; 37: 393-397.

29. Van der Heyde DM, van 't Hof MA, van Riel PL, Theunisse HA, Lubberts EW, van de Putte LBA. Judging disease activity in clinical practice in rheumatoid arthritis: first step in the development of a 'disease activity score'. Ann Rheum Dis 1990; 49: 906-909.

30. Van der Heyde DM, van 't Hof MA, van Riel PL, Theunisse HA, Lubberts EW, Lolkema $W$ et al. Validity of disease activity variables in rheumatoid arthritis. $\mathrm{Br} J$ Rheumatol 1990; 24 (suppl 2): 82.

31. Jeurissen MEC, Boerbooms AMTh, van de Putte LBA, Kruijsen MWM. Azathioprine induced fever, chills, rash and hepatotoxicity in rheumatoid arthritis. Ann Rheum Dis 1990; 49: 25-28.

32. Jeurissen MEC, Boerbooms AMTh, van de Putte LBA. Pancytopenia related to azathioprine in rheumatoid arthritis. Ann Rheum Dis 1988; 47: 503-505 
33. Jeurissen MEC, Boerbooms AMTh, van de Putte LBA. Eruption of nodulosis and vasculitis during methotrexate therapy for rheumatoid arthritis. Clin Rheum 1989; 8: 418419.

34. Lightfoot RW. Treatment of rheumatoid arthritis, Arthritis and allied conditions. Edited by DJ McArthy. Tenth edition, Philadelphia, Lea \& Febiger, 1985.

35. Urowitz MB, Gordon DA, Smythe HA, Pruzanski W, Ogryzlo MA. Azathioprine in rheumatoid arthritis: a double-blind, cross-over study. Arthritis Rheum 1973; 16: 411418.

36. Woodland J, Chaput de Saintonge DM, Evans SJW, Sharman VL, Currey HLF. Azathioprine in rheumatoid arthritis: double-blind study of full versus half doses versus placebo. Ann Rheum Dis 1981; 40: 355-359.

37. Urowitz MB, Hunter Th, Bookman M, Gordon DA, Smythe HA, Ogryzlo MA. Azathioprine in rheumatoid arthritis: a double-blind study comparing full dose to half dose. J Rheumatol 1974; 1: 274-281.

38. Alarcón GS, Tracy JC, Blackburn WD Jr. Methotrexate in rheumatoid arthritis: toxic effects as the major factor in limiting long-term treatment. Arthritis Rheum 1989; 32: 671-676.

39. Weinblatt ME. Toxicity of low-dose methotrexate in rheumatoid arthritis. J Rheumatol 1985; 12: 35-39.

40. Gispen JG, Alarcón GS, Johnson JJ, Acton RT, Barger BD, Koupman WJ. Toxicity to methotrexate in rheumatoid arthritis. J Rheumatol 1987; 14: 74-79.

41. Bunch T, O'Duffy JD. Disease modifying drugs for progression of theumatoid arthritis. Mayo Clin Proc. 1980; 55: 161-179.

42. Whisnant JK, Pelkey J. Rheumatoid arthritis: treatment with azathioprine (Imuran ${ }^{\mathrm{R}}$ ). Clinical side effects and laboratory abnomalities. Ann Rheum Dis 1982; 41: 44-47.

43. Singh G, Fries J, Spitz P, Williams CA. Toxic effects of azathioprine in rheumatoid arthritis: a national postmarketing prospective. Arthritis Rheum 1989; 32: 834-837.

44. Saway PA, Heck LW, Bonner JR, Kerklin JK. Azathioprine hypersensitivity. Case report and review of the literature. Am J Med 1988; 84: 960-964. 


\section{INFLUENCE OF METHOTREXATE AND AZATHIOPRINE ON RADIOLOGIC PROGRESSION IN RHEUMATOID ARTHRITIS. A RANDOMIZED, DOUBLE-BLIND STUDY}

Maurice E.C. Jeurissen', MD, Agnes M.Th. Boerbooms', MD, Levinus B.A. van de Putte', MD, Wim H. Doesburg ${ }^{2}$, MSc, Albert M. Lemmens ${ }^{3}$, MD

Department of Rheumatology, University Hospital Nijmegen ${ }^{1}$

Department of Statistical Consultation, University Hospital Nijmegen ${ }^{2}$

Department of Radiology, University Hospital Nijmegen ${ }^{3}$, The Netherlands.

Ann Intern Med 1991; 114: 999-1004 (Reproduced with permission) 

Objective; To compare the effects of azathioprine and methotrexate on progression of radiologic damage in patients with meumatoid arthritis.

Design: Double-blind, randomized 48-week trial.

Patients: Sixty-four patients with active theumatoid arthritis who either have not responded to or who have reacted with side effects to at least parenteral gold and Dpenicillamine.

Interventions: Either azathioprine, $100 \mathrm{mg}$ daily, or methotrexate, $7.5 \mathrm{mg}$ weekly, was administered orally. Depending on the clinical effect after 8 weeks, the dosage was increased to either azathioprine, $150 \mathrm{mg}$, or methotrexate, $15 \mathrm{mg}$. The dosages for nonsteroidal anti-inflammatory drugs and prednisone were held stable.

Measurements: Clinical and labonatory assessments were done by the same physician every 4 weeks for the first 24 weeks and every 8 weeks thereafter. Radiographs of hands, wrists, and feet obtained at baseline and after 24 and 48 weeks were scored by one rheumatologist blinded to medication and clinical findings.

Main Results: Initial radiologic scores were comparable in both groups and correlated with disease duration $(r=0.38)$. An intention-to-treat analysis after 24 and 48 weeks showed significantly fewer new erosions in the methotrexate group compared with the azathioprine group (difference, 2.0 [95\% CI, 0.2 to 3.9] and 3.5 [CI, 1.3 to 5.8], respectively). The change in total joint score was also significantly less pronounced in the methotrexate group compared with the azathioprine group after 24 weeks (difference, 2.8 ICI, 0.2 to 5.27) and after 48 weeks (difference, 3.9 [CI, 0.3 to 7.4]). Radiologic stabilization after 48 weeks was present in $10 \%$ of the azathioprine group compared with $29 \%$ of the methotrexate group.

Conclusions: Patients with rheumatoid arthritis treated with low-dose methotrexate showed significantly less radiologic progression than patients treated with azathioprine. This result suggests that methotrexate therapy is clinically superior in these patients.

\subsection{INTRODUCTION}

Radiologic damage is one of the most important outcome measures for rheumatoid arthritis (1). Besides suppression of joint inflammation leading to reduction in pain and stiffness, one of the major objectives of therapy with slow-acting antirheumatic drugs is the prevention or slowing of progression of radiologic damage.

Slowing of radiologic progression has been demonstrated for oral gold (2) and sulfasalazine (3) in early rheumatoid arthritis ( $\leq 2$ years) and for parenteral gold $(4,5)$ and perhaps for cyclophosphamide (6) in patients with disease of longer duration. Comparison between azathioprine and other second-line drugs such as parenteral gold (7), D-penicillamine (8), and methotrexate (9), with regard to their inhibitory effect on radiologic progression in patients with disease of long duration, has not shown significant intergroup differences.

On the basis of results of five open prospective studies of low-dose methotrexate in 
rheumatoid arthritis, no definite conclusions can be drawn about a slowing effect of methotrexate on radiologic progression. Two investigators found no radiologic progression and even radiologic improvement after 2 years of therapy in most of their patients (10, 11). Three others found no radiologic improvement and found progression in several patients despite clinical improvement (12-14).

In order to compare the influence of azathioprine and methotrexate on the radiologic progression in rheumatoid arthritis, we evaluated the radiographs of hands, wrists, and feet obtained during a double-blind 48-week study of patients with rheumatoid arthritis. Results described previously (15) have shown the clinical superiority of methotrexate therapy in these patients after 24 and 48 weeks of therapy.

\subsection{PATIENTS AND METHODS}

\section{Patients}

Sixty-four patients with active definite or classical rheumatoid arthritis from five clinics were enrolled from November 1986 to November 1988. The protocol was approved by each institution's ethics committee, and each patient gave informed consent before the study. All patients were either unresponsive to or had had side effects to parenteral gold. Further, three quarters of the patients had received previously hydroxychloroquine and the same percentage of patients had had D-penicillamine. A few patients had also received oral gold and salazopyrine. The dosages of nonsteroidal anti-inflammatory drugs (NSAIDs) and prednisone ( $\leq 10 \mathrm{mg} / \mathrm{d}$ ) were held stable for at least 4 weeks before study entry.

Active rheumatoid arthritis was defined by the presence of at least three of four criteria: six or more joints that were tender or, during motion, were painful; three or more swollen joints; an erythrocyte sedimentation rate above $28 \mathrm{~mm} / \mathrm{h}$; and moming stiffness for at least $\mathbf{4 5}$ minutes. Exclusion criteria included abnormal liver function (any liver function test result exceeding twice the normal value), abnormal renal function (creatinine clearance $<50 \mathrm{ml} / \mathrm{min}$ ), hematologic abnormalities (leukocyte count $<3.5 \mathrm{x}$ $10^{9} / 1$, platelet count $<150 \times 10^{9} / \mathrm{l}$ ), marked obesity (15 kg above ideal weight), insulindependent diabetes mellitus, malignancy, alcoholism, active peptic ulcer disease, functional class IV according to Steinbrocker (16), inadequate contraception, infections, use of allopurinol or antifolate drugs such as sulphonamides, and age less than 16 years or over 75 years.

\section{Study design and medication}

After they were stratified by functional class, patients were randomly allocated by the statistician in blocks of six to receive either methotrexate or azathioprine. The initial dosage of methotrexate was $7.5 \mathrm{mg}$ weekly given in divided doses of $2.5 \mathrm{mg}$ each in three consecutive 12-hour intervals. The initial dosage of azathioprine was $100 \mathrm{mg}$ daily (50 mg twice daily). Using a double-dummy technique, all patients received either two 
tablets containing $50 \mathrm{mg}$ of azathioprine daily with three methotrexate-placebo capsules weekly or three capsules weekly, each containing $2.5 \mathrm{of} \mathrm{mg}$ methotrexate (divided-dosage regimen), with two azathioprine-placebo tablets daily. If the overall clinical improvement (see definition below) was less than partial after 8 weeks, the trial medication was increased to methotrexate, $15 \mathrm{mg}$ weekly, or azathioprine, $150 \mathrm{mg}$ daily. The double-blind protocol was maintained until week $\mathbf{4 8}$ for patients with a good overall improvement after 24 weeks. Patients who had no effect after 24 weeks or who had side effects received the alternative drug in an open phase (that is, azathioprine instead of methotrexate and vice versa) and were followed until week 48 .

\section{Clinical assessments}

Clinical and laboratory evaluations were done every 4 weeks for the first 24 weeks and every 8 weeks thereafter. During the study period, clinical investigations and treatment of the patients studied in the different participating clinics were always done by the same physician. The overall clinical response arbitrarily comprised four disease variables: patient's pain assessment using a visual analog scale from $0 \mathrm{~mm}$ (no pain) to $100 \mathrm{~mm}$ (very severe pain); Ritchie articular index; Westergren erythrocyte sedimentation rate in $\mathrm{mm} / \mathrm{h}$; and moming stiffness expressed in minutes. A good overall improvement was defined as $50 \%$ or more improvement of at least three variables, and partial or moderate improvement was defined as $30 \%$ or more and less than $50 \%$ of at least two of four (and no worsening of other) disease variables. In accordance with other studies $(17,18)$ improvement by $50 \%$ or more in one separate disease variable was considered to be good (marked) improvement, whereas improvement by $30 \%$ or more and less than $50 \%$ was considered to be partial (moderate) improvement.

\section{Radiographic assessment}

Radiographs of hands, wrists, and feet were taken at baseline and after 24 and 48 weeks of treatment. All radiographs had the same quality and granulation. They were all scored by one experienced rheumatologist who was unaware of the clinical and laboratory findings and the drugs the patients had received. The radiographs were evaluated under identical conditions and in chronologic order for each patient. The radiographs of the hand were scored according to the modified method of Sharp (19). Because there is no agreement on scoring radiographs of the feet, we decided to score the radiographs in the way that was recently described in another double-blind trial of rheumatoid arthritis (3). In that study, the maximum possible score of erosions in the joints of the feet was fixed at 10 and that of the hands at 5 because erosions in the feet were much more pronounced than those in the hands.

Erosions in the following joints were counted: the 8 proximal interphalangeal joints, the 2 interphalangeal joints of the thumbs, the 10 metacarpophalangeal joints, the right and left first metacarpal bone, distal right and left bones of the radius and ulna, bones of the right and left carpus (trapezium bone and trapezoid bone [as one unit; multangular], navicular bone and lunate bone). Further, 10 metatarsophalangeal joints and the right and 
left inter-phalangeal joints of the big toes were scored. Erosions were qualitatively scored between 1 to 5 depending on the amount of damage. A minimal interruption of the cortical surface was scored as 1 , whereas larger defects were scored as 2 to 5 , depending on the size of involved surface of the joint. As mentioned before, the maximal erosion score in a joint in the foot was 10 compared with 5 in the hand. The maximum scores for erosions were therefore 160 in the hands and 120 in the feet.

The grades of joint space narrowing were defined as ranging from 1 to 4 ( 1 = focal doubtful; 2 = general; [that is, less than $50 \%$ of the original space involved]; 3 = general but more than $50 \%$ involved, or subluxation; 4 = ankylosis). Joint-space narrowing was assessed in the 8 proximal interphalangeal joints, the 10 metacarpophalangeal joints, third, fourth, and fifth carpometacarpal joints of the right and left hand, right and left multangular-navicular joints, right and left capitate-navicular-lunate joints, right and left radiocarpal joints, the 10 metatarsophalangeal joints, and the 2 interphalangeal joints of the big toe. The maximum scores for joint space narrowing were 120 in the hands and 48 in the feet. The total radiologic score included the erosion score and the joint-space narrowing score.

Depending on the degree of radiologic progression, patients were divided into four categories: no change, change between 1 and 5 , change between 6 and 10 , or change between 11 and 30 . No change in the total score after 24 or 48 weeks was considered to be radiologic stabilization. A change by more than 10 units was considered to be marked radiologic deterioration. To analyze for intra-observer agreement, 30 pairs of radiographs from five patients, chosen at random, were scored twice. To measure the interobserver agreement, the same radiographs were scored by a second experienced rheumatologist.

The results with regard to the reliability of measurements $(R$, also called intraclass correlation), calculated according to Fleiss (20), were as follows: The intra-observer scores showed almost no variation, with an $R$ of 0.99 for erosions and joint-space narrowing in hands and feet. Some degree of variation between observers was found in the measurement for joint-space narrowing in the left hand $(R=0.67)$ and right hand $(R=0.87)$, but very little was found in the feet $(R=0.99)$. The variation between observers with regard to the measurement of erosions in hands and feet was very low $(\mathrm{R}=0.98)$. Because scoring of radiographs was time consuming and the variation between observers was low, all trial radiographs were scored by one observer.

\section{Statistical analysis}

For a group size of 30 patients each, real differences in mean values of at least $0.7 \mathrm{x}$ SD (SD = the standard deviation of the variate under interest, for example, the 24-week change in erosions) will result with a probability of $80 \%$ in a statistically significant difference between the two corresponding sample means (alpha [type I error] $=0.05$, beta [type II error] $=0.20$, two sided t-test). So, in this study it could be expected that real differences in mean 24-week changes in erosions with a magnitude of 3 or more would be significant $(\mathrm{P}<0.05)$.

Differences in demographic characteristics between the two treatment groups were jud- 
Table 1. Demographic, Clinical and Laboratory Variables at Baseline *

\begin{tabular}{|c|c|c|c|}
\hline Baseline Variable & $\begin{array}{l}\text { Azathioprine } \\
(\mathrm{n}=33)\end{array}$ & $\begin{array}{l}\text { Methotrexate } \\
(n=31)\end{array}$ & $P$ value \\
\hline Age, y & $55.8 \pm$ & $57.3 \pm 9.5$ & $>0.2$ \\
\hline Disease duration, $y$ & $9.4 \pm 5.6$ & $12.8 \pm 10.0$ & $>0.10$ \\
\hline $\begin{array}{l}\text { Women:men, n } \\
\text { Functional class }\end{array}$ & $17: 16$ & $26: 5$ & 0.01 \\
\hline $\begin{array}{l}\text { II:III, } \mathbf{n} \\
\text { Number of patients with }\end{array}$ & 26 & $25: 6$ & $>0.2$ \\
\hline HLADR4 & 22 & 19 & $>0.2$ \\
\hline Latex titer $\geq 1: 80$ & 33 & 29 & $>0.2$ \\
\hline Subcutaneous nodules & 11 & 11 & $>0.2$ \\
\hline Joint prosthesis & 7 & 7 & $>0.2$ \\
\hline Tender joints count & $23.0 \pm 10.7$ & $22.5 \pm 10.1$ & $>0.2$ \\
\hline Ritchie articular index & $22.4 \pm 9.6$ & $19.6 \pm 6.5$ & 0.2 \\
\hline Swollen joints count & $18.7 \pm 7.0$ & $18.8 \pm 7.2$ & $>0.2$ \\
\hline Pain score (VAS), mm & $54.6 \pm 21.7$ & $49.6 \pm 18.7$ & $>0.2$ \\
\hline Morning stiffness, min & $109 \pm 83$ & $82 \pm 79$ & 0.19 \\
\hline $\begin{array}{l}\text { Erythrocyte sedimenta- } \\
\text { tion rate, } \mathrm{mm} / \mathrm{h}\end{array}$ & $60.2 \pm 27.9$ & $57.5 \pm 27.9$ & $>0.2$ \\
\hline
\end{tabular}

* Where appropiate, values are expressed as means \pm SD. VAS = visual analog scale; HLADR4 = Human leukocyte antigen DR4.

ged using chi-square tests for nominal variables whereas for other variables, such as age and disease duration, the Student two-sample test was used. Results of radiologic scores were analyzed for patients who completed 24 and 48 weeks of the same drug. These results were also analyzed using an intention-to-treat approach, that is, regardless of whether patients discontinued the trial medication and switched to other second-line drugs. The mean changes in the radiologic scores after 24 and 48 weeks between the two groups were compared first without including possible confounders, using the Student two-sample test, and second including possible confounders, using multiple regression analysis. Ninety-five percent confidence intervals $(95 \% \mathrm{CI})$ were calculated for the differences between those groups in averaged changes for radiologic scores.

\subsection{RESULTS}

Except for gender $(P=0.01)$, demographic and baseline clinical variables did not differ between the 33 patients in the azathioprine group and the 31 patients in the methotrexate group (Table 1). No significant differences in clinical disease variables such as erythrocyte sedimentation rate, Ritchie index, swollen joints, and pain score, however, were found between the female and the male patients treated with azathioprine. Eight patients from the azathioprine group and two patients from the methotrexate group 
already used prednisone ( $\leq 10 \mathrm{mg} / \mathrm{d}$ ) at the start of the study. Initial disease variables did not differ significantly between patients from both treatment groups with and without prednisone. The two treatment groups comprised almost the same number of patients whose disease duration was between 1.5 and 4.5 years (azathioprine, 7; methotrexate, 7); patients whose disease duration was between 4.5 and 9 years (azathioprine, 11; methotrexate, 9); and patients whose disease duration was longer than 9 years (azathioprine, 15; methotrexate, 15).

\section{Clinical response to therapy}

During the treatment period, 13 patients from the azathioprine group were withdrawn within 12 weeks because of severe side effects such as hypersensitivity reactions $(n=3)$, liver dysfunction $(n=3)$, hematologic adverse reactions $(n=2)$, or severe gastrointestinal symptoms $(n=5$ ) (Figure 1). Eight patients in the azathioprine treatment group discontinued azathioprine therapy after 24 weeks because of lack of clinical effect. Fourteen patients who discontinued azathioprine because of side effects or lack of effect switched to methotrexate. The remaining seven patients switched to prednisone $(n=2)$, salazopyrine $(n=3)$, D-penicillamine $(n=1)$, or no drug $(n=1)$ for various reasons, such as severe pancytopenia or prolonged liver dysfunction (both due to azathioprine).

In the methotrexate group four patients discontinued therapy after 24 weeks because of lack of effect and switched to azathioprine. At 24 weeks, two patients from the methotrexate group were withdrawn because of side effects (dermatitis and severe nodulosis, respectively). One of these patients was given azathioprine; the other patient refused other therapy. The number of withdrawals because of side effects in the methotrexate group ( $n=2$ ), was less than the number of withdrawals because of side effects in the azathioprine group $(n=13)(P<0.03)$.

After 8 weeks, $21 \%$ of the patients in the azathioprine group and $54 \%$ in the methotrexate group had a good or partial overall clinial improvement. Twenty patients in the azathioprine group and 30 in the methotrexate treatment group completed 24 weeks of the same drug therapy. A good or partial overall improvement in these same-drug groups at 24 weeks was found in $60 \%$ of the patients treated with azathioprine and in $80 \%$ of patients treated with methotrexate. After 48 weeks, 12 patients in the azathioprine treatment group were still using azathioprine, whereas 24 patients in the methotrexate group were still using methotrexate. A good or partial overall improvement at 48 weeks in these same-drug groups was found in $75 \%$ of the patients treated with azathioprine and $91 \%$ of the patients treated with methotrexate (Figure 1). A good or partial overall improvement at 24 weeks in the intention-to-treat groups was present in $70 \%$ of the azathioprine and $78 \%$ of the methotrexate group. At 48 weeks, a good or partial improvement was present in $70 \%$ of the azathioprine group and $90 \%$ of the methotrexate group.

\section{Radiologic response to therapy}

All available radiologic data were used. The baseline radiographs for one patient from the methotrexate group were missing, and after 24 weeks radiographs for 3 patients from 
Figure 1. Clinical course. Sixty-four patients with rheumatoid arthritis were randomized to receive azathioprine or methotrexate therapy and were followed for 48 weeks. The amount of clinical improvement and the number of patients leaving the trial and their reasons for doing so are shown at various time points. Numbers $=$ number of patients.

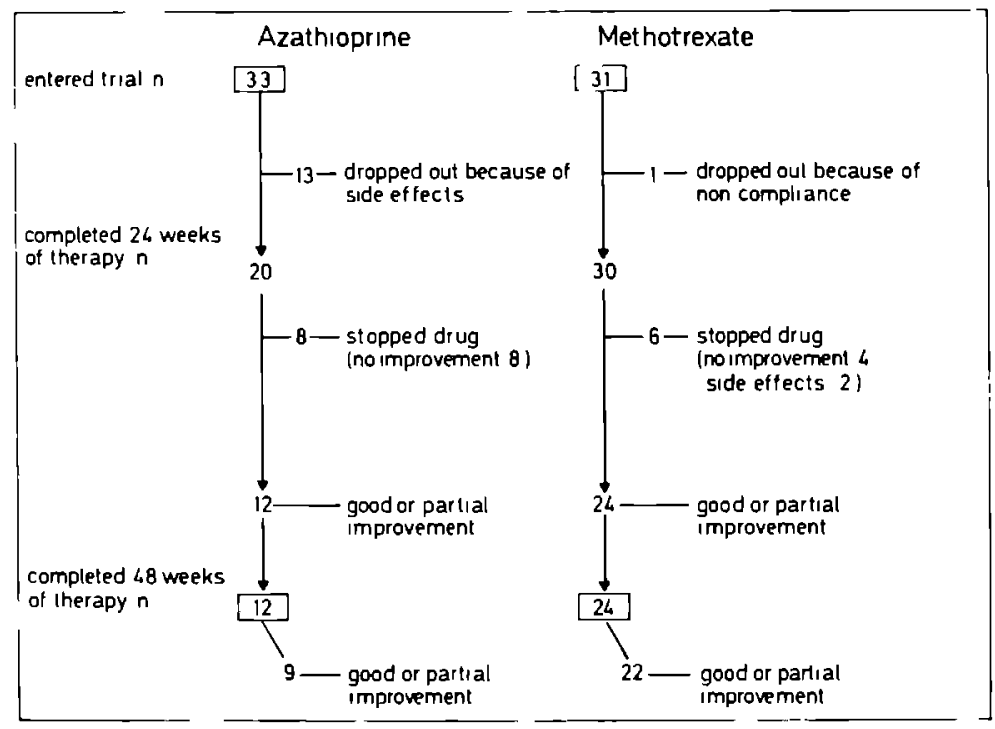

both treatment groups were missing or incomplete. After 48 weeks, radiographs for 3 patients from the methotrexate group were incomplete. At the start of the study the two treatment groups showed no significant differences in erosion score or in total radiologic score (that is, erosions plus joint-space narrowing; Table 2). Scores changed, at most, by 0.2 after adjusting for possible confounders (gender, disease duration) with multiple regression analysis. Clinical activity measurements (Ritchie index, pain score, morning stiffness) also changed only slightly. Therefore only unadjusted estimates are presented.

In the patients who completed 24 weeks of azathioprine, the mean number of new erosions was 3.1 compared with 1.1 in patients who completed 24 weeks of methotrexate therapy (Table 2). After 48 weeks, the number of new erosions was 4.7 and 1.5, respectively $(P=0.01)$. Total joint damage was also less in patients in the methotrexate group. According to an intention-to-treat analysis, results were similar. Fewer new erosions were found in the methotrexate group after 24 weeks (1.2 compared with 3.2 ) and 48 weeks (1.8 compared with 5.3). The change in total joint score also favored the methotrexate group.

The changes in mean erosions (3.1) and in mean total joint score (5.1) in the azathioprine group in the first 24-week period were higher than in the second 24 weeks of the same drug therapy (1.6 and 2.5, respectively). This was also the case in the methotrexate group when the first 24 weeks of therapy (1.1 and 2.3$)$ and the second 24 weeks $(0.4$ and 


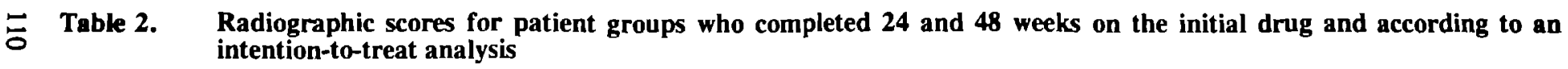

\begin{tabular}{|c|c|c|c|c|c|c|c|c|c|c|c|c|c|c|}
\hline \multirow[t]{3}{*}{ Variable } & \multicolumn{7}{|c|}{$\begin{array}{l}\text { Analysis confined to those patients who } \\
\text { completed therapy with the initial drug }\end{array}$} & \multicolumn{7}{|c|}{ Intention-to-treat analysis } \\
\hline & \multicolumn{3}{|c|}{ Azathioprine } & \multicolumn{3}{|c|}{ Methotrexate } & \multirow{2}{*}{$\begin{array}{l}\text { Difference } \\
(95 \% \mathrm{CI})\end{array}$} & \multicolumn{3}{|c|}{ Azathioprine } & \multicolumn{3}{|c|}{ Methotrexate } & \multirow{2}{*}{$\begin{array}{l}\text { Difference } \\
(95 \% \mathrm{CI})\end{array}$} \\
\hline & $\mathbf{n}$ & mean & (SE) & $\mathrm{n}$ & mean & (SE) & & $n$ & mean & (SE) & n & mean & (SE) & \\
\hline \multicolumn{15}{|l|}{ E score $*$} \\
\hline Baseline & 33 & 37.5 & $(4.1)$ & 30 & 34.4 & $(4.7)$ & & 33 & 37.5 & $(4.1)$ & 30 & 34.4 & $(4.7)$ & \\
\hline 24 weeks & 19 & 3.1 & (1.1) & 26 & 1.1 & $(0.3)$ & $\begin{array}{l}2.0 \\
(-0.1 \text { to } 4.0)\end{array}$ & 30 & 3.2 & $(0.8)$ & 27 & 1.2 & $(0.3)$ & $\begin{array}{l}2.0 \\
(0.2 \text { to } 3.9)\end{array}$ \\
\hline 48 weeks & 12 & 4.7 & (1.5) & 24 & 1.5 & $(0.4)$ & $\begin{array}{l}3.2 \\
(0.7 \text { to } 5.3)\end{array}$ & 33 & 5.3 & $(0.9)$ & 27 & 1.8 & $(0.5)$ & $\begin{array}{l}3.5 \\
(1.3 \text { to } 5.8)\end{array}$ \\
\hline \multicolumn{15}{|l|}{ T score \# } \\
\hline Baseline & 33 & 60.5 & $(6.8)$ & 30 & 62.7 & (8.4) & & 33 & 60.5 & $(6.8)$ & 30 & 62.7 & (8.4) & \\
\hline 24 weeks & 19 & 5.1 & (1.3) & 26 & 2.3 & $(0.8)$ & $\begin{array}{l}2.8 \\
(-0.2 \text { to } 5.6)\end{array}$ & 30 & 5.1 & $(1.0)$ & 27 & 2.4 & $(0.8)$ & $\begin{array}{l}2.7 \\
(0.2 \text { to } 5.2)\end{array}$ \\
\hline 48 weeks & 12 & 7.6 & (1.8) & 24 & 4.0 & (1.0) & $\begin{array}{l}3.6 \\
(-0.5 \text { to } 7.7)\end{array}$ & 33 & 8.6 & $(1.2)$ & 27 & 4.7 & $(0.9)$ & $\begin{array}{l}3.9 \\
(0.3 \text { to } 7.4)\end{array}$ \\
\hline
\end{tabular}

- Erosion score at baseline and change in erosion score after 24 and 48 weeks

- Total score (is the score for erosions plus the score for joint-space narrowing) at baseline and change in total score after 24 and 48 weeks 
1.6) were compared (Table 2).

When radiologic scores were analyzed according to the degree of progression and according to an intention-to-treat analysis (Table 3), after 48 weeks of therapy, $11 \%$ of the methotrexate group and $43 \%$ of the azathioprine group had marked radiologic deterioration ( $>10$ units change in total score). Radiologic stabilization after 48 weeks was found in $29 \%$ of the methotrexate group and in $10 \%$ of the azathioprine group. Calculation of correlation coefficients between the total radiographic score and all demographic, clinical, and laboratory variables at baseline revealed no relation except for disease duration $(r=0.38)$.

\subsection{DISCUSSION}

This study showed that after 48 weeks, fewer new erosions developed in patients who completed 48 weeks of methotrexate therapy than in patients who completed 48 weeks of azathioprine therapy. The total radiologic score at 48 weeks in these patients did not reach statistical significance $(P=0.08)$. The small number of patients on azathioprine who completed 48 weeks of therapy (12), however, limits the statistical power. The number of

Table 3. Changes in radiographic scores according to their degree of change (four categories) and according to an Intention-to-treat analysis

\begin{tabular}{|c|c|c|c|c|}
\hline \multirow[t]{2}{*}{ Variable } & \multicolumn{2}{|c|}{$\begin{array}{l}\text { Azathioprine } \\
(n=30)\end{array}$} & \multicolumn{2}{|c|}{$\begin{array}{l}\text { Methotrexate } \\
(n=27)\end{array}$} \\
\hline & $24 w k$ & $48 w k$ & $24 w k$ & $48 \mathrm{wk}$ \\
\hline \multicolumn{5}{|c|}{ Change in erosions } \\
\hline 0 & 11 & 7 & 12 & 11 \\
\hline 1 to 5 & 10 & 11 & 14 & 13 \\
\hline 6 to 10 & 7 & 7 & 1 & 2 \\
\hline 11 to 30 & 2 & 5 & 0 & 1 \\
\hline \multicolumn{5}{|c|}{$\begin{array}{l}\text { Change in total } \\
\text { score* }\end{array}$} \\
\hline 0 & 4 & 3 & 12 & 8 \\
\hline 1 to 5 & 15 & 10 & 11 & 12 \\
\hline 6 to 10 & 6 & 4 & 2 & 4 \\
\hline 11 to 30 & 5 & 13 & 2 & 3 \\
\hline
\end{tabular}

* The total score is the score for erosions plus the score for joint-space narrowing. A significant difference in distribution of the total score after 24 weeks $(P=0.02)$ and after 48 weeks $(P=0.01)$ was found in favor of the methotrexate group. 
of patients who dropped out because of severe side effects was significantly higher in the patients on azathioprine (Figure 1). An intention-to-treat analysis done to study the final radiologic outcome of all patients after 24 and 48 weeks of therapy also found significantly slower radiologic joint damage after 24 and 48 weeks in the methotrexate group. When patients were divided into four categories according to the severity of radiographic damage during the study period, methotrexate treatment was superior. Although we did not find radiographic improvement in any patient, the number of patients with radiologic stabilization was approximately three times higher in the methotrexate group than in the azathioprine group after 24 and 48 weeks of follow-up. The number of patients with marked radiologic deterioration after 48 weeks of therapy was four times higher in the azathioprine group.

The change in mean number of erosions (that is, new erosions) and mean total joint scores in the first 24 weeks of the same drug therapy was higher than the scores in the second 24 weeks. Although this finding occured in both treatment groups, the changes in the methotrexate group were less than those found in the azathioprine group for both periods. Because radiologic changes spread over time and it takes several months before second-line antirheumatic drugs exert their effect, the favorable radiologic results of metho-trexate compared with the azathioprine group probably reflect the earlier response and the more pronounced clinical effect of methotrexate in this study.

Factors that have been reported to correlate with progression of joint destruction in rheumatoid arthritis are disease duration $(21,22)$; persistently elevated erythrocyte sedimentation rate (23) or C-reactive protein (22-24); Ritchie index (22); hemoglobin (22); immunoglobulin M (22); human leukocyte antigen HLADR4 (25); rheumatoid factor (21, 25); antiperinuclear factor in seronegative patients (26); and clinical outcome, based on the variables of functional grade, joint score, grip strength, and moming stiffness (27). In our patients we found only a modest correlation between the initial mean radiologic score and the disease duration of patients. In both treatment groups a similar number of patients had relatively short and long disease duration. Because all but two patients were positive for the rheumatoid factor, we could not judge the effect of the presence of the rheumatoid factor on the degree of joint destruction.

In three of five open prospective radiologic studies of low-dose methotrexate, radiographs were taken at variable intervals $(10,13,14)$. In two studies $(13,14)$ the interval between the first radiograph (that is, the time of start of methotrexate therapy) and the second ranged from 10 to 50 months (mean, 30 months). In the third study, follow-up radiographs were taken after a minimum of 28 months (10). In two other studies (11, 12), there was a fixed interval of 2 years between the first two radiographs followed by annual radiographs in one study (11). Hand and wrist radiographs were evaluated in three studies $(10,12,14)$, whereas, in the other two studies $(11,13)$ (as in our study), radiographs of the feet were also evaluated. Mean disease duration, method of radiologic assessment, and criteria used for defining clinical improvement were not always comparable in these studies. One group of investigators demonstrated worsening of radiographs in 6 of 14 patients, no change in 3, and radiologic improvement in 5 patients (10). A second group of investigators (11) found radiologic stabilization in all patients and improvement in radiologic scores in several patients after 2 years. After 3 years of methotre- 
xate therapy, however, $36 \%$ of patients had radiologic deterioration (11). Hanrahan and colleagues (12) found radiologic stabilization in 18 of 47 patients on methotrexate after 2 years and marked radiologic deterioration (that is more than 10 units of change in the radiologic score) in 16 patients despite clinical improvement. Nordstrom and colleagues (13) suggested that methotrexate could not significantly alter the rate of radiologic progression. Reykdal and colleagues (14) showed slowing of radiologic progression in 8 of 15 patients. The mean rate of radiologic progression in 15 patients during methotrexate therapy, however, did not differ significantly from the rate of radiologic progression before methotrexate treatment (14). Interpretation of the results of all five studies is limited by lack of an adequate control group. Comparison of our radiologic results with those from another double-blind trial of azathioprine compared with methotrexate (9) is difficult, because the number of patients with radiographs available for evaluation after one year in that study was probably too small (azathioprine, 12; methotrexate, 9) to yield significant results.

We have shown that after 1 year of therapy, patients who started on methotrexate therapy had significantly better radiologic results compared with patients who started on azathioprine therapy. The slowing of damage in the joints of the hands, wrists, and feet in favor of methotrexate suggests that administering methotrexate before azathioprine is preferable in patients with rheumatoid arthritis.

\section{Acknowledgment}

The authors thank Mrs. Bianca Schippers for administrative assistance and the following colleagues for allowing us to study patients under their care: M.W. Kruijsen, J.J. Rasker, J.F. Haverman, H.J. van Beusekom and W. Hissink Muller, M.J.A.M. Franssen and D.J.R.A.M. de Rooy.

Grant Support: By a grant from the Dutch League against Rheumatism. The trial medication was supplied by Wellcome and Lederle.

Requests for Reprints: Maurice E.C. Jeurissen, MD, Department of Rheumatology, University Hospital Nijmegen, P.O. Box $9101,6500 \mathrm{HB}$ Nijmegen, The Netherlands.

\section{REFERENCES}

1. Sharp JT. Radiologic assessment as an outcome measure in rheumatoid arthritis. Arthritis Rheum. 1989; 32: 221-9.

2. Borg G, Allander E, Lund B, Berg E, Brodin U, Petterson H, Trang I. Auranofin improves outcome in early rheumatoid arthritis. Results from a 2-year, double-blind placebo controlled study. J Rheumatol. 1988; 15: 1747-54. 
3. Van der Heyde DM, Van Riel PL, Nuver-Zwart IH, Gribnau FW, Van de Putte LBA. Effects of hydroxychloroquine and sulfasalazine on progression of joint damage in rheumatoid arthritis. Lancet. 1989; i: 1036-8.

4. Sigler JW, Bluhm GB, Duncan H, Sharp JT, Ensign DM, McCrum WR. Gold salts in the treatment of rheumatoid arthritis. A double-blind study. Ann Intern Med. 1974; 80: 21-6.

5. A controlled trial of gold salt therapy in rheumatoid arthritis. Arthritis Rheum. 1973; 16: 353-8.

6. A controlled trial of cyclophosphamine in rheumatoid arthritis. N Engl J Med. 1970; 283: 883-9.

7. Dwosh IL, Stein HB, Urowitz MB, Smythe HA, Hunter T, Ogryzlo MA. Azathioprine in early rheumatoid arthritis. Comparison with gold and chloroquine. Arthritis Rheum. 1977; 20: 685-92.

8. Berry H, Liyanage SP, Durance RA, Barnes CG, Berger LA, Evans S. Azathioprine and D-penicillamine in treatment of rheumatoid arthritis: a controlled trial. BMJ 1976; 1: 1052-5.

9. Handy H, McKendry RJ, Mierins E, Liver JA. Low-dose methotrexate compared with azathioprine in the treatment of rheumatoid arthritis. Arthritis Rheum. 1987; 30: 361-8.

10. Weinblatt ME, Trentham DE, Fraser PA, et al. Long-term prospective trial of low-dose methotrexate in rheumatoid arthritis. Arthritis Rheum. 1988; 31: 167-75.

11. Kremer JM, Lee JK. A long-term prospective study of the use of methotrexate in rheumatoid arthritis. Arthritis Rheum. 1988; 31: 577-84.

12. Hanrahan PS, Scrivens GA, Russell AS. Prospective long-term follow-up of methotrexate therapy in rheumatoid arthritis: toxicity, efficacy and radiological progression. Br J Rheumatol. 1989; 28: 147-53.

13. Nordstrom DM, West SG, Andersen PA, Sharp JT. Pulse methotrexate therapy in rheumatoid arthritis. A controlled prospective roentgenographic study. Ann Intern Med. 1987; 107: 797-801.

14. Reykdal S, Steinsson K, Sigurjonsson K, Brekkan A. Methotrexate treatment of rheumatoid arthritis: effects on radiological progression. Scand J Rheumatol. 1989; 18: 221-6.

15. Jeurissen MEC, Boerbooms AMTh, van de Putte LBA. Superiority of methotrexate to azathioprine in advanced rheumatoid arthritis. Results of a randomized double blind trial. [Abstract] Arthritis Rheum. 1990; 33: S39.

16. Steinbrocker $\mathrm{O}$, Traeger $\mathrm{CH}$, Batterman RC. Therapeutic criteria in rheumatoid arthritis. JAMA. 1949; 140: 659-62.

17. Weinblatt ME, Coblyn JS, Fox DA, et al. Efficacy of low-dose methotrexate in rheumatoid arthritis. N Engl J Med. 1985; 312: 818-22.

18. Williams HJ, Willkens RF, Samuelson CO Jr, et al. Comparison of low-dose oral pulse methotrexate and placebo in the treatment of rheumatoid arthritis. A controlled clinical trial. Arthritis Rheum. 1985; 28: 721-30.

19. Sharp JT, Young DY, Bluhm GB, et al. How many joints in the hands and wrists should be included in a score of radiologic abnormalities used to assess rheumatoid arthritis? Arthritis Rheum. 1985; 28: 1326-35.

20. Fleiss JL. Reliability of measurement. In: Fleiss JL, ed. The Design and Analysis of Clinical Experiments. New York: John Wiley \& Sons; 1986: 1-27.

21. Fuchs HA, Kaye JJ, Callahan LF, Nance EP, Pincus T. Evidence of significant radiographic damage in rheumatoid arthritis within the first 2 years of disease. $J$ Rheumatol. 1989; 16: 585-91.

22. Sjöblom KG, Saxne T, Pettersson H, Wollheim FA. Factors related to the progression of joint destruction in rheumatoid arthritis. Scand J Rheumatol. 1984; 13: 21-7.

23. Amos RS, Constable TJ, Crockson RA, Crockson AP, McConkey B. Rheumatoid arthritis: relation of serum C-reactive protein and erythrocyte sedimentation rates to radiographic changes. Br Med J. 1977; 1: 195-7.

24. Thompson PW, Silman AJ, Kirwan JR, Currey HL. Articular indices of joint inflammation in rheumatoid arthritis. Correlation with the acute-phase response. Arthritis Rheum. 1987; 30: 618-23.

25. Calin A, Elswood J, Klouda PT. Destructive arthritis, rheumatoid factor, and HLA-DR4. Arthritis Rheum. 1989; 32: 1221-5. 
26. Westgeest AA, Boerbooms AMTh, Jongmans $M$, Vanden Broucke JP, Vierwinden G, van de Putte LBA. Antiperinuclear factor: indicator of more severe disease in seronegative rheumatoid arthritis. J Rheumatol. 1987; 14: 893-7.

27. Brook A, Fleming A, Corbett M. Relationship of radiological change to clinical outcome in rheumatoid arthritis. Ann Rheum Dis. 1977; 36: 274-5. 

Chapter 8

\section{SERIAL PULMONARY FUNCTION TESTS \\ DURING A RANDOMIZED, DOUBLE-BLIND \\ TRIAL OF AZATHIOPRINE VERSUS \\ METHOTREXATE IN RHEUMATOID ARTHRITIS}

Maurice EC Jeurissen', MD, Agnes MTh Boerbooms', MD, Jan Festen², MD, Levinus van de Putte', MD, Wim Doesburg ${ }^{3}$, MSc.

Department of Rheumatology', Pulmonology ${ }^{2}$, and Statistical Consultation ${ }^{3}$, University Hospital Nijmegen, The Netherlands

Submitted for publication 



\subsection{ABSTRACT}

The ain of this study was to investigate whether periodic pubmonary function tests and chest matiographs were useful for detecting methotrexate (MTX)-induced pubmonary toxicity in theumotoid arthritis (RA). It was also investigated whether pre-existent pulmonary abnomalities were a risk factor for development of MTX pneumonitis.

In a randomized, double-blind study of 64 patients with active refractory theumatoid arthritis (RA), patients received initially either arathioprine (AZA), $100 \mathrm{mg}$ daily, or $M T X, 7.5 \mathrm{mg}$ weekly omily. Depending on the clinical effect after 8 weeks the dosage was increased to $150 \mathrm{mg} \mathrm{AZA}$ or $15 \mathrm{mg}$ MTX. Ertensive pubmonary function tests (spirometry, flow volume curves, $C O$ diffusion, compliance) and chest radiographs were performed at baseline, after 24 weeks and after 2 years.

Results of baseline pubmonary function tests, performed in 52 patients (27 AZA; 25 MTX), were not significantly different between the two groups and showed abnomal results in one or more function tests in 15 to $50 \%$ of patients. Five patients had radiographic signs of lung fibrosis, one pleural effusion, and one pubmonary nodules. After 24 weeks and 2 years, results of pubmonary function tests and chest radiographs showed no changes either within the two groups or between both groups. Patients with pre-eristent lung abnormality did not develop MTX-induced pubmonary toxicity. An association between presence of kerutoconjunctivitis sicce and small airways disease in $R A$ was confirmed.

Conclusion: The results of this study suggest no need for periodic pulmonary funetion tests and chest radiographs during MTX therupy in RA. Patients with pre-existent pulmonary abnomalities did not develop MTX-induced pubnonary toxicity, suggesting that these potients are not more at risk for MTX-induced pneumonitis than others.

\subsection{INTRODUCTION}

Methotrexate-induced pulmonary toxicity is an uncommon but potentially fatal adverse reaction of low-dose methotrexate therapy in rheumatoid arthritis (RA) $(1,2)$. Therefore pulmonary function tests and chest $\mathrm{X}$-rays were performed in RA patients who entered a double-blind study of azathioprine (AZA) compared with methotrexate (MTX) (3).

The major objective of this study was to investigate whether periodic pulmonary function tests and chest X-rays were useful for detecting MTX-induced pulmonary toxicity. The patients on azathioprine therapy served as a control group. We also were interested in the question whether pre-existent pulmonary abnormalities (mainly lung fibrosis) were a risk factor for development of MTX-induced pulmonary toxicity. A question of secondary importance was whether there was an association between the presence of keratoconjunctivitis sicca in RA and the presence of small airways disease. 


\subsection{PATIENTS AND METHODS}

Patients. Sixty-four patients with active classical or definite RA, were enrolled in the period November 1986 and November 1988. All the patients were refractory to or reacted with toxicity to at least parenteral gold. Three quarters of the patients had used hydroxychloroquine and also three quarters of patients had previously received D-penicillamine. Active RA was defined by the following four criteria: six or more joints tender or painful at motion, three or more swollen joints, Westergren erythrocyte sedimentation rate (ESR) above $28 \mathrm{~mm} /$ first hour, morning stiffness for at least 45 minutes. Excluded from the study were patients with abnormal liver function tests (liver enzymes twice the normal value), renal clearance less than $50 \mathrm{ml} / \mathrm{min}$, hematological abnormalities (leucocytes $\leq 3.5 \times 10^{\circ} / 1$ or platelets $\leq 150 \times 10^{\circ} / 1$ ), insulin dependent diabetes mellitus, malignancy, alcohol abuse (more than 4 oz/day), active peptic ulcer disease, (recurrent) infections, inadequate contraception, use of allopurinol or antifolate drugs such as sulfonamide derivatives, age $<16$ or $>75$ years, and functional class according to Steinbrocker (4). The protocol of the study was approved by the Ethical Committee and each patient gave informed consent prior to the study entry.

Patients were randomly allocated to receive either MTX or AZA in blocks of six patients. Stratification for functional class (4) II or III was made. Initially patients received either two tablets of $50 \mathrm{mg}$ AZA daily and three placebo capsules MTX weekly at three consecutive 12-hour intervals or 3 capsules each containing $2.5 \mathrm{mg}$ MTX (divided dose regimen) weekly and two placebo tablets of AZA daily (double dummy technique). Patients with less than partial 'overall' improvement (definition see below) after 8 weeks received the increased dosage schedule viz. AZA, $150 \mathrm{mg}$ daily, or MTX, $15 \mathrm{mg}$ weekly, during the double-blind phase of the study.

A good 'overall' improvement was defined as 50 percent or more improvement of at least three of four disease variables [Ritchie articular index, ESR, pain score (visual analogue scale) and moming stiffness]. A partial improvement was defined as improvement of 30 to 50 percent in at least two of the four disease variables and no worsening of the remaining variables compared with initial values. Only in patients with good overall improvement at week 24 was trial medication continued until week 48 using the double-blind protocol. Withdrawal of the initial drug followed in patients with no effect after week 24 , or in patients with serious adverse reactions to the drug at any time during the study period. These patients received the alternative drug in an open phase viz. AZA instead of MTX and vice versa, unless contraindicated. Therapy with AZA or MTX was also continued after week 48 depending on the clinical effect at that time and on absence of toxicity. The disease activity was assessed with the validated disease activity score (DAS) (5), consisting of the variables Ritchie articular index, swollen joints count, ESR and general health (visual analog scale).

The dosages of nonsteroidal anti-inflammatory drugs (NSAIDs) and prednisone ( $\leq 10$ $\mathrm{mg} /$ day) were held stable for at least 4 weeks before study entry and also throughout the study.

Patients came from 5 different clinics, but clinical investigation of all the patients during the study period was done by the same physician (M.J). Clinical assessments 
(number of tender joints, Ritchie articular index, number of swollen joints, assessment of pain and general health using a visual analog scale of $0-100 \mathrm{~mm}$, morning stiffness, gripstrength) and laboratory assessments were carried out every 4 weeks for the first 24 weeks and thereafter every 8 weeks until week 48 . A complete medical history and physical examination were performed at the start of the study and repeated after 24 and 48 weeks, and after 2 years. With regard to smoking status, smokers were considered to be those who currently smoked, non-smokers those who had never smoked, ex-smokers those who had smoked. A Schirmer test was considered abnormal when $5 \mathrm{~mm}$ or less of the paper slip was wet. Only patients with sicca symptoms and/or abnormal Schirmer test (twice $<5 \mathrm{~mm}$ ) were examined by an ophthalmologist. In these latter patients rose bengal staining on slit lamp examination of the eyes was performed. A chest radiograph was made at baseline and after 2 years.

Pulmonary function tests. Lung volumes were obtained by standardized helium dilution techniques with a spirometer (Pulmonet III, Gould). All volumes were corrected for standard conditions of BTPS (body temperature, pressure, saturation) and expressed as percentages of the predicted values $(6,7)$. Forced expiratory volume in one second $\left(\mathrm{FEV}_{1}\right)$ was assessed from a forced expiration into the spirometer. Flow-volume curves and forced vital capacity (FVC) were assessed by means of the pneumoscreen of Jaeger. Flow-volume curves were obtained by plotting flow ( $V$ in $1 / \mathrm{sec}$ ) against volume ( $\mathrm{V}$ in $\mathrm{l}$ ) during a maximal expiration manoeuvre. The parameters MEF50 and MEF25 (Maximum Expiratory Flow) were defined as the values when $50 \%$ and $25 \%$ of FVC, respectively, still have to be expelled (8). The diffusion capacity (DLCO) was measured using the single breath method with carbon monoxide (Transfer screen II, Jaeger). The values of DLCO were corrected for hemoglobin concentration (8). The lung compliance (semistatic) was obtained by means of an esophageal balloon and measured in the body box (Body screen II, Jaeger). According to the guidelines of the American Thoracic Society, normal values of total lung capacity (TLC), vital capacity (VC), DLCO and compliance are $\pm 20 \%$ of the predicted values (6). The ratio $\mathrm{FEV}_{1} / \mathrm{FVC}$ had to exceed $75 \%$ of the predicted values (6). A ratio $\mathrm{FEV}_{1} / \mathrm{FVC}$ below $75 \%$ is indicative of obstructive lung disease (6). MEF50 and MEF25 are considered abnormal if the values of these parameters are less than $60 \%$ of the predicted values $(7,8)$. Isolated MEF50 $<60 \%$ suggests small airways disease (8), whereas TLC and VC $<80 \%$ suggest restrictive lung disease (9).

Statistical analysis. Since patients were randomly allocated to the two treatments, there was only a $5 \%$ chance of statistically significant differences in baseline variables. Nevertheless we assessed the results of the allocation procedure by standard statistical tests. Differences in characteristics between the two treatment groups were assessed with chi-square tests for nominal variables whereas for continuous variables such as age and disease duration, Student two-sample test was applied. Differences in results of pulmonary function tests after 24 weeks and 2 years within each group were assessed with the Student one-sample test. Clinical and laboratory variables and changes in patients who continued on the same drug for 24 weeks and for 2 years were assessed. 
Table 1. Demographic characteristics and disease variables at baseline of 64 patients with rbeumatoid arthritis treated with either azathioprine or methotrexate

$\begin{array}{ll}\text { Azathioprine } & \text { Methotrexate } \\ (\mathrm{N}=33) & (\mathrm{N}=31)\end{array}$

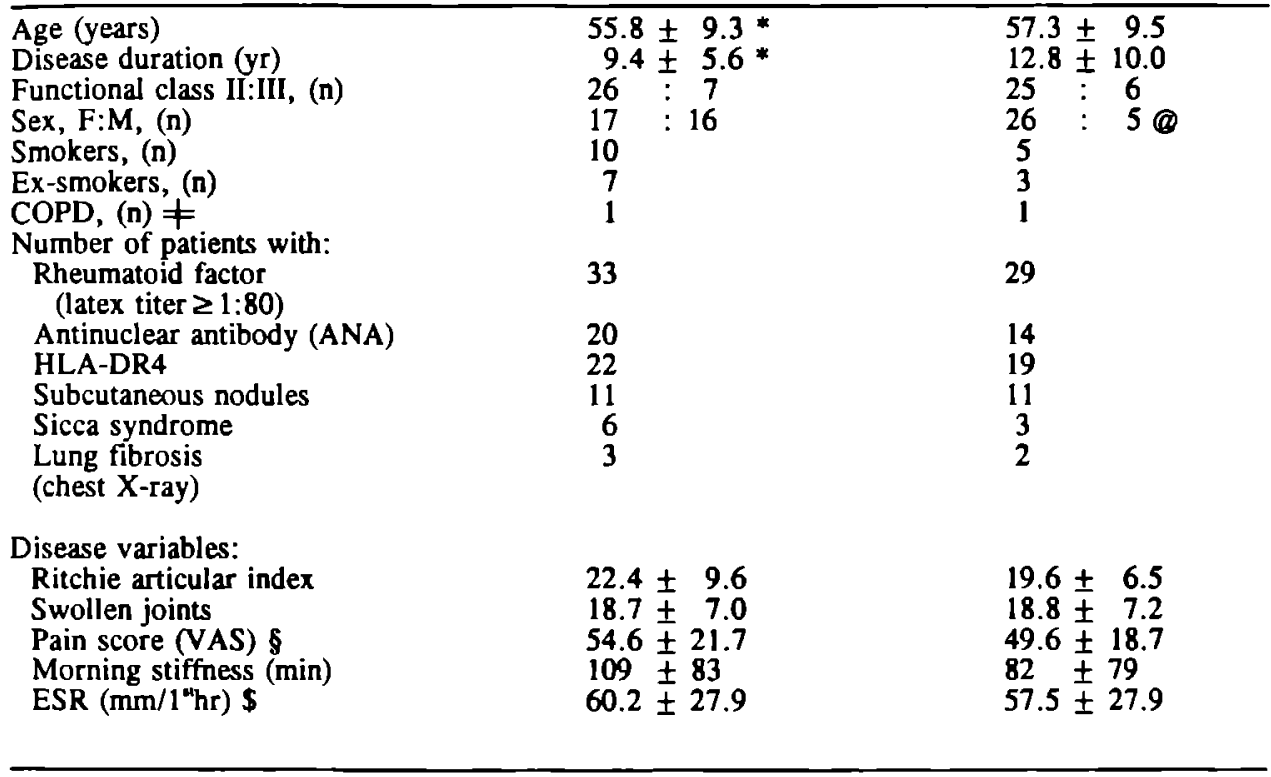

* Mean \pm s.d.

@ Significant difference $(p=0.01)$ between the two groups

$\neq$ Chronic obstructive pulmonary disease

$\$$ Visual analogue scale, $0 \mathrm{~mm}$ meaning no pain and $100 \mathrm{~mm}$ very severe pain

$\$$ Erythrocyte sedimentation rate in $\mathrm{mm}$ in first hour

Regarding to the clinical disease activity, an improvement by 1.08 of the disease activity score (DAS) was considered to be significant (5).

\subsection{RESULTS}

Demographic and clinical features of the $33 \mathrm{AZA}$ and 31 MTX patients at the start of the study were comparable except for a significant difference in gender (Table 1). Twenty AZA and 30 MTX patients completed 24 weeks of AZA and MTX respectively. At the time of data collection 35 patients (18 AZA; 17 MTX), had completed 2 years of follow-up. A significant improvement of the DAS at 24 weeks was found in 6 AZA and 18 MTX patients. After two years, 4 of the 18 patients from the AZA group still used 
Table 2. Baseline values of pulmonary function tests and changes after 24 weeks of azathioprine or methotrexate therapy expressed as percentages of predicted values

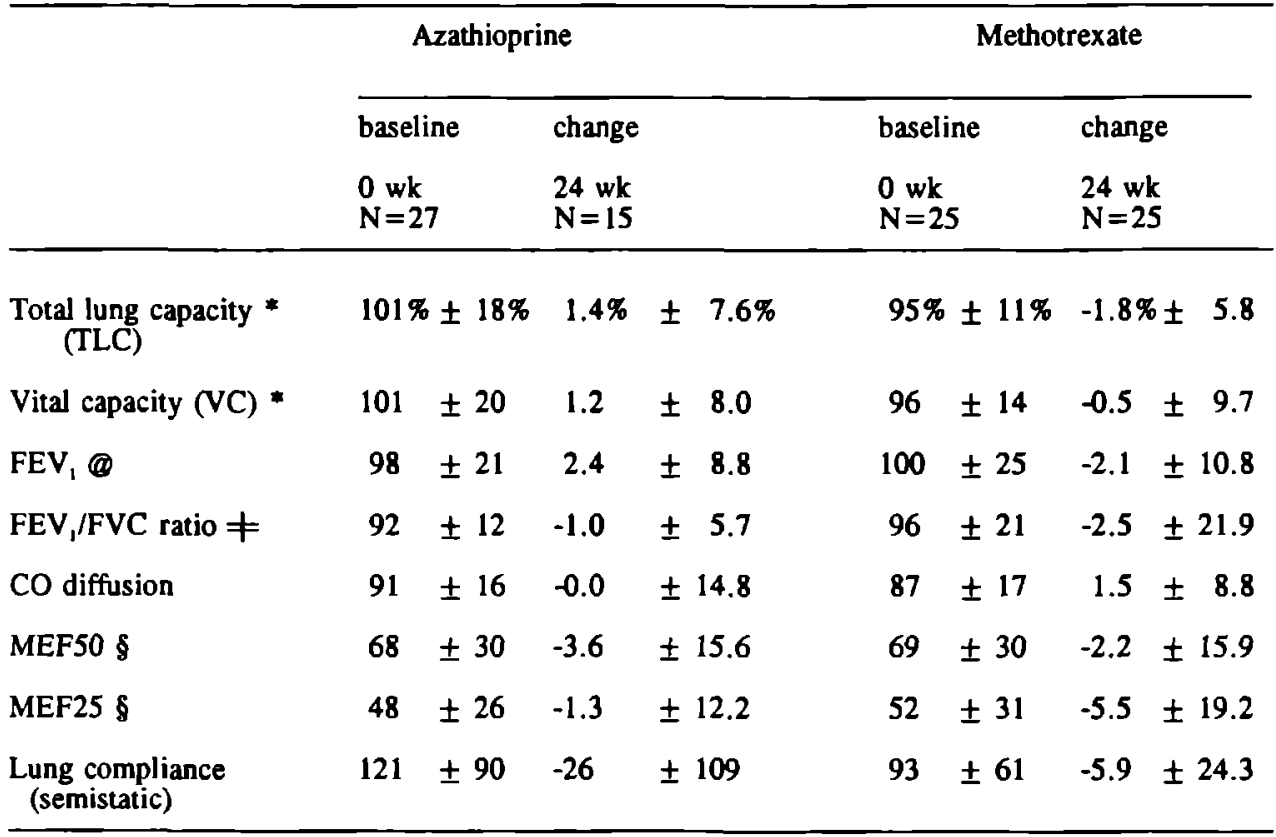

* $\quad \pm$ Standard deviation (normal value of TLC and VC $\geq 80 \%$ )

(Q FEV 1 = forced expired volume in one second (normal value $\geq 80 \%$ )

$\neq \mathrm{FVC}^{\prime}=$ forced vital capacity (nomal value of $\mathrm{FEV}_{1} / \mathrm{FVC} \geq 75 \%$ )

$\$$ MEF50 and MEF25 mean maximal expiratory flow when $50 \%$ and $25 \%$ respectively of FVC still had to be expelled (normal values $\geq 60 \%$ of predicted)

AZA, whereas 11 of the 17 patients from the MTX group still used MTX. Significant clinical improvement after 2 years was found in 4 AZA and 7 MTX patients. The number of withdrawals due to severe side effects was significantly $(P=0.03)$ higher in the AZA group compared with the MTX group (13 versus 2 patients). In 2 MTX-treated patients pneumonia was diagnosed. The causative agent was unknown. MTX was temporarily ( 3 weeks) discontinued and patients received antibiotics.

At study entry pulmonary function tests were performed in $27 \mathrm{AZA}$ and $25 \mathrm{MTX}$ patients. In the first 6 patients of the trial (4 AZA, $2 \mathrm{MTX}$ ), no pulmonary function tests were performed. Owing to other reasons (technical difficulties, refusal), pulmonary function tests were performed in 15 of $20 \mathrm{AZA}$ and 25 of $30 \mathrm{MTX}$ patients (Table 2). At 2 years we had results of pulmonary function tests from 19 of 35 patients. None of the patients had respiratory symptoms at the start of the study. In 9 patients (6 AZA, 3 MTX) basal rales were heard on initial physical examination. During follow-up no increa- 
Table 3. Number of RA patients with normal or decreased pulmonary function tests at the start of the study and after 24 weeks of therapy with azathioprine or methotrexate

\begin{tabular}{|c|c|c|c|c|}
\hline & \multicolumn{2}{|c|}{ Azathioprine } & \multicolumn{2}{|c|}{ Methotrexate } \\
\hline & $\begin{array}{l}0 w k \\
N=15\end{array}$ & $\begin{array}{l}24 w k \\
N=15\end{array}$ & $\begin{array}{l}0 \text { wk } \\
\mathrm{N}=25\end{array}$ & $\begin{array}{l}24 \text { wk } \\
N=25\end{array}$ \\
\hline & \multicolumn{4}{|c|}{ Number of patients } \\
\hline $\begin{array}{l}\text { Normal TLC* } \\
\text { Decreased TLC @ }\end{array}$ & $\begin{array}{r}13 \\
2\end{array}$ & $\begin{array}{r}13 \\
2\end{array}$ & $\begin{array}{r}20 \\
5\end{array}$ & $\begin{array}{r}22 \\
3\end{array}$ \\
\hline $\begin{array}{l}\text { Normal VC } \\
\text { Decreased VC }\end{array}$ & $\begin{array}{r}13 \\
2\end{array}$ & $\begin{array}{r}12 \\
3\end{array}$ & $\begin{array}{r}21 \\
4\end{array}$ & $\begin{array}{r}20 \\
5\end{array}$ \\
\hline $\begin{array}{l}\text { Normal FEV } \\
\text { Decreased FEV, }\end{array}$ & $\begin{array}{r}11 \\
4\end{array}$ & $\begin{array}{r}12 \\
3\end{array}$ & $\begin{array}{r}21 \\
4\end{array}$ & $\begin{array}{r}20 \\
5\end{array}$ \\
\hline $\begin{array}{l}\text { Normal FEV } / F V C \\
\text { Decreased } \mathrm{FEV}_{1} / \mathrm{FVC}\end{array}$ & $\begin{array}{r}13 \\
2\end{array}$ & $\begin{array}{r}12 \\
3\end{array}$ & $\begin{array}{r}21 \\
4\end{array}$ & $\begin{array}{r}20 \\
5\end{array}$ \\
\hline $\begin{array}{l}\text { Normal CO diffusion } \\
\text { Decreased CO diffusion }\end{array}$ & $\begin{array}{r}10 \\
5\end{array}$ & $\begin{array}{l}9 \\
6\end{array}$ & $\begin{array}{r}18 \\
7\end{array}$ & $16 \neq$ \\
\hline $\begin{array}{l}\text { Normal MEF50 } \\
\text { Decreased MEF50 }\end{array}$ & $\begin{array}{l}8 \\
7\end{array}$ & $\begin{array}{l}9 \\
6\end{array}$ & $\underset{12}{9 \neq}$ & $\underset{9}{12} \neq$ \\
\hline $\begin{array}{l}\text { Normal MEF25 } \\
\text { Decreased MEF25 }\end{array}$ & $\begin{array}{r}5 \\
10\end{array}$ & $\begin{array}{l}6 \\
9\end{array}$ & $\begin{array}{r}7 \\
14\end{array}$ & $\begin{array}{r}7 \neq \\
14\end{array}$ \\
\hline $\begin{array}{l}\text { Normal static compliance } \\
\text { Decreased static compliance }\end{array}$ & ${ }_{4}^{11} \neq$ & $\underset{2}{12} \neq$ & ${ }_{9}^{8} \neq$ & $\frac{6}{8} \neq$ \\
\hline
\end{tabular}

- $\quad$ TLC = Total lung capacity; VC = vital capacity; $F E V_{1}=$ forced expiratory flow in one second FVC = forced vital capacity; MEF50 and MEF25 = maximal expiratory flow when 50 and $25 \%$ respectively of FVC still have to be expelled.

(6) Decreased values of TLC, VC, $\mathrm{FEV}_{1}, \mathrm{CO}$ diffusion and Static Compliance are values below $80 \%$ of predicled; FEV /FVC ratio $<75 \%$ is abnormal; decreased MEF50 and 25 are results below $60 \%$ of predicted values.

\# Several functions tests were measured in fewer patients than the total group of 15 AZA and 25 MTX patients due to refusal, technical difficulties or other reasons.

se of rales was found. After 24 weeks we found no significant changes in pulmonary function tests either within each group or between the two groups (Table 2).

In Table 3 pulmonary function tests are presented in a different way. For each of the function tests, patients were divided in two categories: having normal or decreased values at baseline and week 24 . At study entry $15 \%$ of the patients had restrictive lung disease. Thirty-seven percent of the patients had abnormal CO diffusion, whereas in 50\% abnor$\mathrm{mal}$ flow/volume curves were found. Half of the patients with abnormal flow/volume curves were smokers or ex-smokers. A low semistatic compliance was observed in more 
Table 4. Pulmonary function tests expressed as percent predicted values after 24 weeks and 2 years of continued MTX therapy in 9 RA patients

\begin{tabular}{llcc}
\hline & 0 wk & 24 wk & 2 years \\
\hline TLC @ & $95 \pm 9 \% *$ & $94 \pm 9 \%$ & $98 \pm 7 \%$ \\
VC & $94 \pm 13 \%$ & $93 \pm 14 \%$ & $96 \pm 10 \%$ \\
FEV $_{1}$ & $92 \pm 31 \%$ & $93 \pm 26 \%$ & $99 \pm 26 \%$ \\
FEV $/$ /FVC & $85 \pm 24 \%$ & $97 \pm 16 \%$ & $91 \pm 17 \%$ \\
CO diffusion & $84 \pm 20 \%$ & $84 \pm 20 \%$ & $86 \pm 20 \%$ \\
MEF50 & $70 \pm 47 \%$ & $77 \pm 35 \%$ & $69 \pm 36 \%$ \\
MEF25 & $54 \pm 39 \%$ & $61 \pm 20 \%$ & $54 \pm 27 \%$ \\
Semistatic compliance & $121 \pm 88 \%$ & $109 \pm 73 \%$ & $107 \pm 55 \%$ \\
\hline
\end{tabular}

- Mean \pm SD

(9) Abbreviations as in Tables 2 and 3

than $50 \%$ of the patients who started on MTX and in $25 \%$ who started on AZA. The number of patients who had abnormal pulmonary function tests at the start of the study was almost equal to the number of patients with abnormal function tests at week 24 (Table 3). Because of the low number of AZA patients ( 3 patients) who completed 2 years of the same therapy and of whom pulmonary function tests were done, only the results of pulmonary function tests of 9 MTX patients at 2 years are listed in Table 4. This table shows no changes in pulmonary function tests after 2 years of weekly MTX. Otherwise the pulmonary function tests of the three AZA patients did also not change. Comparison of initial chest radiographs with those at 2 years did not show any substantial changes.

A Schirmer test performed in 58 patients was abnormal in 14 patients. A false positive test (absence of sicca symptoms and normal rose bengal test) was found in 5 of the 14 patients (36\%). In 9 patients (15\%) keratoconjunctivitis sicca was diagnosed. Two of the 9 patients lack sicca symptoms. Labial salivary gland biopsies were not performed. In Table 5 it is demonstrated that 6 of the 9 patients with keratoconjunctivitis sicca had small airways disease based on the findings of MEF50. All but one patient was positive for HLA-DR4 antigen and rheumatoid factor.

\subsection{DISCUSSION}

To our knowledge this is the first controlled study in which the role of periodic pulmonary function tests and chest radiographs is evaluated for monitoring MTX-induced pulmonary toxicity in RA. In 1987 it was recommended to perform baseline and annual chest radiographs and pulmonary function tests in RA patients treated with low-dose MTX 
Table 5. Characteristics of 9 RA patients (6 AZA; 3 MTX) with keratoconjunctivitis sicca $(\mathrm{KCS})$ *

Variable

Number of patients

$\begin{array}{ll}\text { Decreased MEF50 @ } & 6 \\ \text { Decreased MEF25 @ } & 6 \\ \text { Abnormal FEV,FVC } & 1 \\ \text { Abnormal CO diffusion } \S & 2 \\ \text { Lung fibrosis (chest X-ray) } & 0 \\ \text { Non smokers } & 6 \\ \text { Latex titer } \geq 1: 80 & 9 \\ \text { ANA } & 4 \\ \text { HLA-DR } & 8 \\ \text { Subcutaneous nodules } & 8\end{array}$

- Diagnosis based on least 2 of 3 criteria: history of dry eyes, abnormal Schirmer, abnormal rose bengal staining on slit lamp examination

(1) $\leq 60 \%$ of predicted values

$\neq \leq 75 \%$ of predicted values

$\$ \leq 80 \%$ of predicted values

until more data were available (10). The prevalence of MTX-induced pneumonitis in large scale studies of RA patients ranges from 3 to $5.5 \%(1,11,12)$.

At study entry demographic and clinical characteristics (except for gender) as well as values of pulmonary function tests were equal in patients treated with AZA or MTX. The clinical data revealed that more patients on MTX than on AZA showed significant clinical improvement, whereas more patients on AZA developed serious (non-pulmonary) side effects leading to withdrawal.

In order to get detailed information of possible changes in the lung, extensive pulmonary function tests and chest radiographs were performed. Baseline pulmonary function tests showed that a considerable percentage (15-50\%) of RA patients had one or more abnormal pulmonary function tests. These percentages agree with percentages reported in the literature: 0 to $20 \%$ for restrictive lung disease $(8,13), 30$ to $80 \%$ for small airways disease $(8,13,14,15,16)$, and 25 to $70 \%$ for decreased CO diffusion $(8,16)$. Results of studies evaluating chronic obstructive airways disease in RA are often difficult to interpret due to confounding effects of smoking and concurrent restrictive lung disease (17). However, obstructive lung disease in a subgroup of non smoking RA patients with Sicca syndrome has been demonstrated $(13,17,18)$.

The mean results of pulmonary function tests expressed as percentages of predicted values in our study were comparable with results reported elsewhere (17), except for lower results of MEF50 in our patients. After 24 weeks we found no significant changes in pulmonary function tests either within each treatment group or between the patients from the MTX or the AZA group (Tables 2 and 3). In an uncontrolled study of 34 RA patients treated with MTX also no significant changes in three measured pulmonary function tests (VC, $F E V_{1}$, and CO diffusion) were found. The time of pulmonary function testing in that study ranged from 34 to 52 weeks (19). 
After 2 years of continued MTX therapy we did not find important changes in pulmonary function tests or chest radiographs. The 24 weeks and 2 years findings of this study suggest that there is no need for periodic testing of pulmonary function or chest radiographs during treatment with MTX in RA. The number of studied patients, however, was relatively small, mainly the 2 -year group.

Based on retrospective findings and small numbers of patients two authors $(12,20)$ have suggested that pre-existent lung disease (lung fibrosis, decreased $\mathrm{CO}$ diffusion) and smoking history (12) may predispose to MTX pneumonitis. In a large sized (154 RA patients) study, clear predisposing factors for MTX pneumonitis were lacking (11). In our study we did not find MTX-induced pulmonary toxicity, not even in patients with pre-existent pulmonary abnormalities: ten patients on MTX had one or more signs of pulmonary abnormalities of whom 4 had decreased $\mathrm{CO}$ diffusion, 3 radiographic signs compatible with lung fibrosis, 1 had pulmonary nodules, decreased $\mathrm{VC}$ and $\mathrm{CO}$ diffusion ( $<50 \%$ of normal), 1 pleural effusion and 1 patient chronic obstructive pulmonary disease $\left(\mathrm{FEV}_{1} 40 \%\right.$ of normal value). In all these patients pulmonary function tests and chest radiographs remained stable during MTX therapy. The 2 MTX-treated patients with pneumonia were nonsmokers, had no immunoglobulin deficiency or pre-existent lung abnormality. The clinical findings, response to antibiotics, and disease course, argued against a diagnosis of MTX pneumonitis.

In accordance with the literature $(13,18)$ we could confirm the association between presence of keratoconjunctivitis sicca in RA and presence of small airways disease and the HLA-DR4 antigen. We also found that all but one patient in this subgroup of RA patients $(\mathbf{N}=9)$ had subcutaneous nodules. Since only 3 of these 9 patients smoked, none of them had recurrent respiratory infections or restrictive lung disease, abnormal flowvolume curves in this subgroup may represent small airways disease as an extra-articular feature of RA. Airflow obstruction in these patients is considered to be caused by lymphocytic infiltration of bronchioles $(13,18)$.

In conclusion we have demonstrated that pulmonary function tests and chest radiographs do not change in RA patients treated with MTX (or AZA). Patients with preexistent lung disease did not develop MTX-induced pulmonary toxicity in this study. An association between the presence of keratoconjunctivitis sicca in RA and small airway disease was confirmed. In view of the prevalence of MTX-induced pulmonary toxicity, we recommend to have baseline chest radiographs and pulmonary function tests (spirometry, CO diffusion) before starting MTX in RA patients. The results of this study suggest no need for periodic pulmonary function tests and chest radiograph during MTX therapy. Long-term prospective studies of larger number of patients are necessary for definite conclusions. 
The authors thank Mrs Bianca Schippers for typing the manuscript and the following colleagues for allowing us to study patients under their care: M.W.M Kruijssen, J.J Rasker (Medisch Spectrum Twente), H.J van Beusekom, W. Hissink Muller (Maria and Elisabeth Hospital Tilburg), J.F Haverman (Bosch Medicentrum 's Hertogenbosch), M.J.A.M Franssen, D.J.R.A.M de Rooy (St Maartenskliniek Nijmegen).

\section{REFERENCES}

1. St Clair W, Rice JR, Snydermann R. Pneumonitis complicating low-dose methotrexate therapy in rheumatoid arthritis. Arch Int Med 145: 2035-2038, 1985

2. Newmann ED, Harrington ThM. Fatal methotrexate pneumonitis in rheumatoid arthritis. Arthritis Rheum 31: 1585-1586, 1988

3. Jeurissen MEC, Boerbooms AMTh, van de Putte LBA, Doesburg WH, Mulder J, Rasker JJ, Kruijsen MWM, Haverman JF, van Beusekom HJ, Hissink Muller W, Franssen MJAM, de Rooy DJRAM. Methotrexate versus azathioprine in the treatment of rheumatoid arthritis. A forty-eight week randomized, double-blind trial. Arthritis Rheum (in press)

4. Steinbrocker O, Traeger ChM, Battermann RC. Therapeutic criteria in rheumatoid arthritis. JAMA 140: 659-662, 1949

5. Van der Heijde DMFM, Van 't Hof MA, van Riel PLCM, Theunisse LAM, Lubberts EW, van Leeuwen MA, van Rijswijk MH, van de Putte LBA. Judging disease activity in clinical practice in rheumatoid arthritis: first step in the development of a disease activity score. Ann Rheum Dis 49: 916-920, 1990

6. Renzetti AD, Blecker ER, Epler GR, Jones RN, Kamer RE, Ripsker LH. American Thoracic Society. Evaluation of impairment/disability secondary to respiratory disorders. Am Rev Resp Dis 133: 1205-1209, 1986

7. Mountz JD, Turner RA, Collins RL, Gallup KL, Semble EL. Rheumatoid arthritis and small airways function. Effects of disease activity, smoking and $\alpha_{1}$-antitrypsin deficiency. Arthritis Rheum 27: 728-736, 1984

8. Andounopolos RP, Drosos AA, Skopouli FN, Acritidis NC, Moutsopolos HM. Secondary Sjögren's syndrome in theumatoid arthritis. J Rheumatol 14:1098-1103, 1987

9. Garcia JG, James HL, Zinkgraf S, Perlman MB, Keogh BA. Lower respiratory tract abnormalities in rheumatoid interstitial disease. Am Rev Resp Dis 136: 811-818, 1987

10. Tugwell $\mathbf{P}$, Benett $\mathbf{K}$, Gent $\mathbf{M}$. Methotrexate in rheumatoid arthritis. Indications, contraindications, efficacy, and safety. Ann Intern Med 107: 358-366, 1987

11. Carson CW, Cannon GW, Egger MJ, Clegg DO. Pulmonary disease during the treatment of rheumatoid arthritis with low-dose pulse methotrexate. Semin Arthritis Rheum 16: 186195,1987

12. Searles G, McKendry RJR. Methotrexate pneumonitis in rheumatoid arthritis. Potential risk factors. Four case reports and a review of the literature. J Rheumatol 14: 1164-1171, 1987

13. Radoux V, Menard HA, Begin R, Decary F, Koopman WJ. Airways disease in rheumatoid arthritis patients. One element of a general exocrine dysfunction. Arthritis Rheum 30: 249-256, 1987

14. Collins RL, Turner RA, Johnson AM, Whitley NO, Mclean RL. Obstructive pulmonary disease in rheumatoid arthritis. Arthritis Rheum 19: 623-628, 1976

15. Geddes DM, Webley M, Emerson PA. Airways obstruction in rheumatoid arthritis. Ann Rheum Dis 38: 222-225, 1979

16. Vitali C, Viegi G, Tassoni S, Tavoni A, Paoletti P, Bibolotti E, Ferri C, Bombardieri S. Lung function abnormalities in different connective tissue diseases. Clin Rheumatol 5: 181-188, 1986

17. Gordon DA, Hyland RH, Broder I. Rheumatoid Arthritis. The Lung in Rheumatic Diseases. First Edition. Edited by GW Cannon, GA Zimmerman. New York, Basel, Marcel Dekker, 1990 
18. Begin R, Masse S, Cautin A, Menard H, Bureau M. Airways disease in a subset of non smoking theumatoid arthritis patients. Characterization of the disease and evidence for an auto-immune pathogenesis. Am J Med 72: 743-750, 1982

19. Furst DE, Zavala D, Monick $\mathbf{M}$, Hanser $\mathbf{M}$, Humminghake G. Pulmonary function testing and broncho-alveolar lavage (BAL) in rheumatoid arthritis patients on low-dose methotrexate. Arthritis Rheum 29 (Suppl): S17, 1986

20. Bell MJ, Geddie WR, Gordon DA, Reynolds WJ. Pre-existing lung disease in patients with rheumatoid arthritis (RA) may predispose to methotrexate (MTX) lung. Arthritis Rheum 29: S75, 1986 

Chapter 9

\section{RARE SIDE EFFECTS OF AZATHIOPRINE AND METHOTREXATE}



Chapter 9.1

\section{PANCYTOPENIA RELATED TO AZATHIOPRINE IN RHEUMATOID ARTHRITIS}

M.E.C. Jeurissen, A.M.Th. Boerbooms, L.B.A. van de Putte

Department of Rheumatology, University Hospital Nijmegen, The Netherlands

Ann Rheum Dis 1988; 47: 503-505 (Reproduced with permission) 

Two patients with rheumatoid arthritis developed pancytopenia during treatment with azathioprine $100 \mathrm{mg}$ daily. In one patient this side effect occurred after three weeks, in the other after eight weeks of treatment. Rapid fall of platelets in one patient necessitated platelet transfusion. In the other patient additional treatment with allopurinol was probably responsible for the toxic effect. Haematological side effects of azathioprine are discussed.

Key words: adverse drug reaction, bone marrow suppression

Azathioprine has been extensively used for more than 20 years in the treatment of patients with rheumatoid arthritis (RA) who are unresponsive or react with side effects to gold salts or D-penicillamine, or both. At a dosage of $1.5-2.5 \mathrm{mg} / \mathrm{kg} /$ day the toxic reactions of azathioprine are moderate and limited mainly to gastrointestinal and mild haematological complications $(1,2)$.

Pancytopenia in relation to this drug is a rare side effect. So far, 18 cases of pancytopenia during azathioprine treatment used for a variety of diseases, given in different dosages and in combination with different other drugs, have been reported world wide (3). Detailed descriptions of these cases are mostly lacking.

We report two patients with rheumatoid arthritis who developed pancytopenia while receiving azathioprine $100 \mathrm{mg}$ daily. In one patient platelet transfusion was necessary because of severe thrombocytopenia. The pancytopenia disappeared in both patients after azathioprine treatment was stopped.

\section{CASE REPORTS}

Case 1.

A 36 year old woman was diagnosed as suffering from seropositive RA in November 1974. Besides non-steroidal anti-inflammatory drugs she was treated successively with hydroxychloroquine, gold thioglucose, and D-penicillamine.

D-Penicillamine had to be discontinued twice owing to dermatitis. In August 1985 this drug had to be stopped permanently on account of leucopenia $\left(2.4 \times 10^{9} / \mathrm{l}\right)$ and thrombocytopenia $\left(60 \times 10^{9} / 1\right)$. Other abnormal laboratory findings were a positive antinuclear antibody (ANA) test and on immunoblotting weak anti-Sm and antihistone antibodies. Physical examination was normal and there were no signs of active arthritis. Drug induced systemic lupus erythematosus was suspected, and she was treated with prednisone for several months.

Because of active erosive RA involving wrists, knees, and proximal interphalangeal joints of the hands treatment with azathioprine $100 \mathrm{mg}$ daily was started on 12 February 1987. Except for indomethacin $150 \mathrm{mg}$ daily she took no other drug. Three weeks after starting azathioprine RA activity was diminished. Blood tests showed leucopenia of $1.6 \mathrm{x}$ $10^{9} / 1$ and thrombocytopenia of $78 \times 10^{9} / 1$. Azathioprine was immediately stopped. Five 
Figure 1. Haematological changes during azathioprine and indomethacin treatment in patient 1 . ( $\checkmark=$ one unit of platelet transfusion)

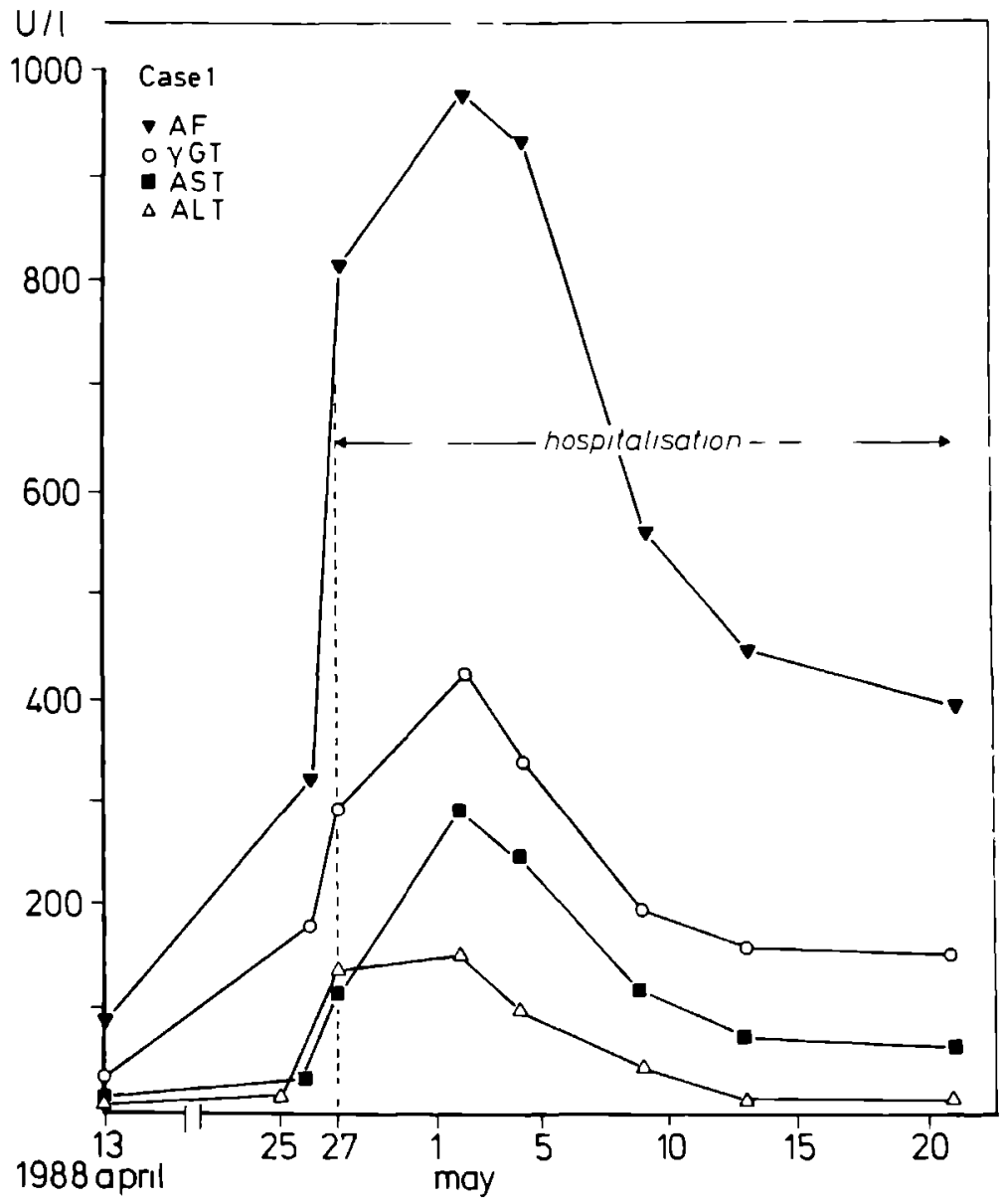

days later the platelet count fell to $27 \times 10^{9} / 1$. Petechiae developed on her legs and she was admitted to hospital. Examination showed little RA activity. Laboratory findings were erythrocyte sedimentation rate (ESR) $60 \mathrm{~mm} / 1 \mathrm{st} \mathrm{h}$, haemoglobin $90.2 \mathrm{~g} / \mathrm{l}$, platelets $18 \times 10^{9} / 1$, leucocytes $1.8 \times 10^{9} / 1$ with $47 \%$ granulocytes. Mean corpuscular volume (MCV) was $81 \mathrm{fmol} / 1$, reticulocytes $0.2 \%$. Except for a positive ANA test and antidouble-stranded DNA (anti dsDNA) of $57 \mathrm{U} / 1$ (normal less than $20 \mathrm{U} / 1$ ), other laboratory tests, including lactic dehydrogenase, direct Coombs', antibodies to platelets and granulocytes, complement, and immunoblotting, showed no abnormalities. HLA analysis was A2, A28, B15, Bw4, Bw6, DR1, DQw1. A bone marrow biopsy showed a hypocellular marrow with a shift of the myeloid series towards immaturity. Megakaryocytes 
were absent and the erythroid precursors were partly megaloblastic.

The pancytopenia was considered most probably to be related to azathioprine. From the first day in hospital indomethacin was also stopped. Treatment with prednisone 60 $\mathrm{mg}$ daily was started and reduced in 10 days to a $5 \mathrm{mg}$ maintenance dose. Two days after admission platelet transfusion was necessary because of a rapid fall of the platelets to $4 \times 10^{9} / 1$. Otherwise there were no other problems. The lowest value of the leucocytes was $1.4 \times 10^{\circ} / 1$ and of haemoglobin $75.7 \mathrm{~g} / 1$ (Fig. 1).

After three weeks in hospital the patient was dismissed with a haemoglobin of $90.2 \mathrm{~g} / \mathrm{l}$, reticulocytes $4.5 \%$, leucocytes $2.7 \times 10^{\%} / 1$, and platelets $173 \times 10^{9} / 1$. Later a marrow biopsy specimen was completely normal and anti-dsDNA was repeatedly negative. At this time she felt well. Her only treatment being prednisone $5 \mathrm{mg}$ daily.

\section{Case 2.}

A 68 year old man was diagnosed as suffering from seropositive RA in January 1976. He was then treated successively with hydroxychloroquine and gold thioglucose. Because of a recurrent duodenal ulcer he received a maintenance dosage of cimetidine $400 \mathrm{mg}$ daily. In January 1985 hyperuricaemia and nephrolithiasis from urate calculi were detected, and treatment with allopurinol $100 \mathrm{mg}$ daily was started. One year later he was admitted to hospital because of active RA involving wrists, knees, proximal interphalangeal and metacarpophalangeal joints of the hand. Subcutaneous nodules were present. Abnormal laboratory findings were ESR $81 \mathrm{~mm} / 1 \mathrm{st} \mathrm{h}$, haemoglobin $114.3 \mathrm{~g} / \mathrm{l}$, creatinine $118 \mu \mathrm{mol} / \mathrm{l}$, and a creatinine clearance of $70 \mathrm{ml} / \mathrm{min}$. Treatment with azathioprine $100 \mathrm{mg}$ daily was started. In addition to allopurinol and cimetidine, the patient had taken indomethacin $125 \mathrm{mg}$ daily for several years. At the end of February 1986 a declining haemoglobin $(82.1 \mathrm{~g} / 1)$ occurred without melena or positive benzidine reaction. Values of leucocytes and platelets were normal. Gastroscopy showed superficial erosions in the bulbus. Two weeks later the patient was readmitted with pancytopenia. Physical examination was unchanged. Laboratory results were as follows: ESR $122 \mathrm{~mm} / 1 \mathrm{st} \mathrm{h}$, haemoglobin $69.2 \mathrm{~g} / \mathrm{l}, \mathrm{MCV} 90 \mathrm{fmol} / 1$, reticulocytes $0.1 \%$, platelets $50 \times 10^{\circ} / \mathrm{l}$, leucocytes $2.8 \times 10^{9} / 1$ with normal differential cell count. Renal function was unchanged. Other laboratory values were normal, including iron, folic acid, and vitamin $\mathbf{B}_{12}$.

Bone marrow biopsy showed only a decreased number of megakaryocytes. After discontinuation of azathioprine, allopurinol, and indomethacin the counts of leucocytes and platelets returned to normal in two weeks. Two units of packed red blood cells were administered. Because of active RA azathioprine was restarted three weeks after admission at a dosage of $50 \mathrm{mg}$ but now without allopurinol. Daily blood tests were performed. The dosage was increased after one week to $100 \mathrm{mg}$, but the drug had to be discontinued owing to isolated thrombocytopenia of $107 \times 10^{\circ} / 1$. As the RA activity persisted, prednisone $10 \mathrm{mg}$ daily was started and the platelet count became normal within one week.

\section{DISCUSSION}

These two patients with RA developed pancytopenia induced by azathioprine. Bacon et 
al. have reported two patients with this serious side effect (4). They emphasized in one patient the possible additional role of allopurinol. In our second patient also allopurinol probably played a part in the development of pancytopenia.

Azathioprine is an imidazole derivative of 6-mercaptopurine with immunosuppressive and anti-inflammatory effects. Its mode of action is based on incorporation of a false purine, leading to alteration and inhibition of the purine, DNA, and RNA synthesis. Haematological side effects of azathioprine are dependent on the dosage. When the usual dosage $(1.5-2.5 \mathrm{mg} / \mathrm{kg} /$ day $)$ is given the interval before maximum bone marrow suppression is about two weeks (5). We found the same interval in patient 1 .

Leucopenia is the most frequent haematological complication of azathioprine treatment. In published reviews about this adverse drug reaction in patients with RA the incidence of leucopenia ranges from 11 to $14.5 \%(1,2)$. Agranulocytosis within one week of azathioprine administration is very rare and possibly an idiosyncratic reaction (5). Other haematological changes are thrombocytopenia, anaemia, and macrocytosis. Thrombocytopenia is an uncommon side effect reported in $0.8-4.8 \%$ of cases $(1,2)$. It rarely develops without leucopenia. In our second patient isolated thrombocytopenia developed two weeks after restarting azathioprine. Pure red cell aplasia induced by azathioprine is a very rare adverse reaction. It reflects a selective toxic effect of azathioprine on erythropoiesis $(6,7)$. Macrocytosis has been reported in transplant recipients and ascribed to interference with DNA synthesis (7-9). It is unrelated to the metabolism of folic acid or vitamin $B_{12}$, or both. In our patients we could not find a significant alteration in the $\mathrm{MCV}$. In the second patient a declining haemoglobin concentration occurred two weeks before the leucopenia and thrombocytopenia. When the negative result of the gastroscopy and the laboratory values are considered the anaemia appears to be related to azathioprine.

In the case of patient 1 the general practitioner had not brought to our notice the haematological changes (leucocytes $3.3 \times 10^{\circ} / 1$, platelets $123 \times 10^{\circ} / 1$ ) a week before she visited us. At that time we could have discontinued or diminished the dosage. An additional toxic effect of indomethacin on the bone marrow was unlikely because she had taken that drug for many years. In retrospect, owing to the absence of megakaryocytes from the bone marrow and the absence of antibodies to granulocytes and platelets, the indications for administering high dosage prednisone were debatable. As she had developed leucopenia and thrombocytopenia while taking D-penicillamine in the past she may have been predisposed to bone marrow suppression due to different drugs.

There are several reports of pancytopenia due to the combination of azathioprine and allopurinol (10-12), as occurred in patient 2 . Azathioprine is rapidly converted to 6mercaptopurine. The major metabolite of 6-mercaptopurine, 6-thiouric acid, is excreted in the urine. The enzyme xanthine oxidase is responsible for this oxidation. Allopurinol inhibits this enzyme and so administration of azathioprine together with allopurinol gives rise to an increased 6-mercaptopurine blood concentration, which can induce bone marrow toxicity. If it is necessary to administer both drugs it is advisable to reduce the usual dose of azathioprine by about $75 \%(3,5)$. In patient 2 this rule was unfortunately not applied.

Finally, when azathioprine is prescribed, close clinical and laboratory controls are 
necessary. Increased toxicity due to additional drugs has to be considered. Fortunately, both these patients recovered completely from this rare but dangerous adverse reaction to azathioprine.

\section{Acknowledgment}

We wish to thank Mrs. Marion Janssen for her excellent secretarial help.

\section{REFERENCES}

1. Whisnant JK, Pelkey J. Rheumatoid arthritis: treatment with azathioprine (Imuran ${ }^{\mathrm{R}}$ ). Clinical side-effects and laboratory abnormalities. Ann Rheum Dis 1982; 41(suppl): 44-7.

2. Bunch ThW, O'Duffy DM. Disease modifying drugs for progressive rheumatoid arthritis. Series on pharmacology in practice. Mayo Clin Proc 1980; 55: 161-79

3. Lawson DH, Lovatt GE, Gurton GS, Hennings RC. Adverse effects of azathioprine. Adverse Drug React Acute Poisoning Rev 1984; 3: 161-71.

4. Bacon BR, Treuhaf WH, Goodman AM. Azathioprine-induced pancytopenia. Arch Intern Med 1981; 141: 223-6.

5. Decker JL, Steenberg AD. Immunoregulatory drugs. In: McCarty DJ ed. Arthritis and allied conditions. Philadelphia: Lea and Febiger, 1985; 529-30

6. Old CW, Flannery EP, Grogan ThM, Stone WH, San Antonio RP. Azathioprine induced pure red blood cell aplasia. JAMA 1978; 240: 552-4.

7. McGrath BP, Ibels LS, Raik E. Erythroid toxicity of azathioprine. Q J Med 1975; 173: 57-63.

8. Nicholls AJ, Davidson RJ. Development of macrocytosis during azathioprine therapy after renal transplantation. Transplantation 1978; 27: 220-1.

9. Wickramasinghe SN, Dodsworth H, Rault RM. Observations on the incidence and cause of macrocytosis in patients on azathioprine following renal transplantation. Transplantation 1974; 18: 443-6.

10. Reinicke H, Weber FW, Hausamen TU. Myelosuppression mit Makrozytärer Anămie und Leukopenie unter Behandlung mit Azathioprine bei Myastenia gravis. Dtsch Med Wochenschr 1982; 107: 1592-4.

11. Zazgornik J, Kopsa H, Schmidt P, Pils P, Kuschan K, Deutsch E. Increased danger of bone marrow damage in simultaneous azathioprine-allopurinol therapy. Int $\mathbf{J}$ Clin Pharmacol Ther Toxicol 1981; 19: 96-7.

12. Glogner $\mathbf{P}$, Henri N. Panzytopenie nach Kombinationsbehandlung mit Allopurinol und Azathioprine. Medizinische Welt 1976; 277: 1545-6. 

Chapter 9.2

\section{AZATHIOPRINE INDUCED FEVER, CHILLS, RASH, AND HEPATOTOXICITY IN RHEUMATOID ARTHRITIS}

M.E.C. Jeurissen ${ }^{1}$, A.M.Th. Boerbooms', L.B.A. van de Putte', M.W.M. Krựjsen²

Department of Rheumatology, University Hospital Nijmegen'; Medisch Spectrum Twente ${ }^{2}$, The Netherlands

Ann Rheum Dis 1990; 49: 25-27 (Reproduced with permission) 

Within one year three of 25 patients with meumatoid arthritis treated with azathioprine $100 \mathrm{mg}$ daily developed the following adverse reactions less than two weeks after stanting treatment: patient one showed fever with chills, mash, and severe liver function abnomalities suggestive of cholestasis; the second patient had fever, nausea, diarrhoea, and modenately raised liver enzymes; the thind patient showed very high fever and severe chills. In two patients the drug was rechallenged, with more rapidly arising and more severe symptoms. In one case raised liver enzymes persisted until seven months after discontinuation of azathioprine. Hypersensitivity reactions and hepatotoxicity of azathioprine are discussed.

Hypersensitivity reactions to azathioprine -for example, fever, myalgia, arthralgia, and rash- are well known, but rare, adverse reactions to the drug (1). To our knowledge the combination of liver function abnormalities with fever, chills, and rash has been reported before in only two patients (2). Recently, we observed in one year three patients with rheumatoid arthritis (RA) treated with $100 \mathrm{mg}$ azathioprine daily who developed fever and chills with liver function abnormalities (two patients) and rash (one patient).

The clinical picture of these three patients is described and allergic adverse reactions to azathioprine and the hepatotoxicity of the drug are discussed.

\section{CASE REPORTS}

Case 1. A 49 year old man was diagnosed as having seropositive RA since 1972. He had been successively treated with parenteral gold and D-penicillamine. Both drugs were ineffective. For several years he also took diclofenac $150 \mathrm{mg}$ daily.

In April 1988 treatment with azathioprine (100 mg daily) was started because of active RA involving shoulders, elbows, hands, and feet. Laboratory findings were as follows: erythrocyte sedimentation rate (ESR) $42 \mathrm{~mm} / \mathrm{h}$ and haemoglobin $130 \mathrm{~g} / \mathrm{l}$. Apart from an increased concentration of IgA $4.5 \mathrm{~g} / 1$ (normal $<2.6 \mathrm{~g} / \mathrm{l}$ ), other laboratory values were normal. Ten days after starting azathioprine he developed fever $\left(38.5^{\circ} \mathrm{C}\right)$ with severe chills, diarrhoea, and dermatitis of his hands. Azathioprine was discontinued and laboratory values showed a greatly increased ESR of $108 \mathrm{~mm} / \mathrm{h}$, alkaline phosphatase $317 \mathrm{U} / \mathrm{l}$ (normal $<120 \mathrm{U} / 1$ ), and gamma-glutamyltransferase $176 \mathrm{U} / 1$ (normal $<40 \mathrm{U} / \mathrm{l}$ ). Two days later the clinical situation worsened and he was admitted to hospital. Apart from severe dermatitis of his hands with vesicles and pustules and a moderately active RA, physical examination on admission was normal. Laboratory findings were as follows: ESR $93 \mathrm{~mm} / \mathrm{h}$, haemoglobin $120 \mathrm{~g} / \mathrm{l}$, leucocytes (including eosinophils) and platelets normal. Alkaline phosphatase $810 \mathrm{U} / 1$, gamma-glutamyltransferase $295 \mathrm{U} / 1$, serum aspartate aminotransferase (AST) $127 \mathrm{U} / 1$ (normal $<25 \mathrm{U} / \mathrm{l}$ ), serum alanine aminotransferase (ALT) $150 \mathrm{U} / 1$ (normal <30 U/l). Bilirubin total and direct slightly raised at 26 and 18 $\mu \mathrm{mol} / 1$ (normal $<10 \mu \mathrm{mol} / 1$ and $1 \mu \mathrm{mol} / 1$ respectively), lactic dehydrogenase and amylase normal. 
Figure 1. Changes of liver function tests [alkaline phosphatase (AP), G-glutamyltransferase (GGT), serum aspartate aminotransferase (AST), serum alanine aminotransferase (ALT)] during treatment of patient No 1 with azathioprine and diclophenac.

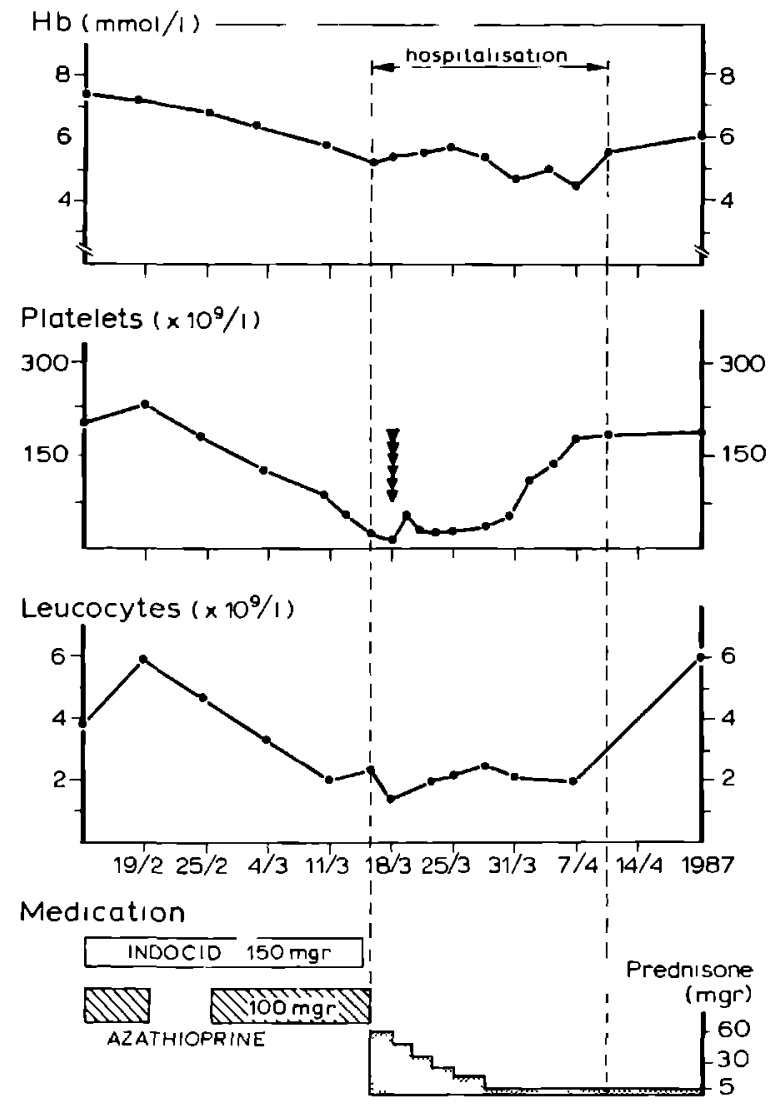

Blood cultures showed no growth. Tests for syphilis, hepatitis $\mathbf{A}$ and $\mathbf{B}$, and cytomegalovirus were negative. Antinuclear antibody, antibodies against mitochondria and smooth muscle were also negative. HLA typing: A2, B5, B15, Bw62, Bw4, Bw6, DR4, DRw52, DQw2, DQw3. Ultrasonography of gall bladder, biliary tract, liver, and pancreas was normal.

Because all liver enzymes rose further (maximum alkaline phosphatase $935 \mathrm{U} / 1$, AST $290 \mathrm{U} / \mathrm{l})$ a liver biopsy was performed. Histological examination showed only some (peri)portal infiltration and several necrotic liver cells, but neither cholestasis nor cirrhosis. The figure shows the course of the liver function tests. He was dismissed with diclofenac $150 \mathrm{mg}$. In July 1988 the RA was more active and prednisone $7.5 \mathrm{mg}$ daily was started. The liver enzymes normalized only seven months after dismissal. 
Case 2. A 63 year old woman had been suffering from seropositive RA since 1977. Besides indomethacin $150 \mathrm{mg}$ daily she had been treated with hydroxychloroquine sulphate, D-penicillamine (thrombocytopenia), oral gold tablets (ineffective), and sulphasalazine (fever, exanthema). She refused parenteral gold treatment. In March 1987 she was admitted to hospital because of active RA involving knee, hands, wrists, and shoulders. The ESR was $97 \mathrm{~mm} / \mathrm{h}$, haemoglobin $115 \mathrm{~g} / \mathrm{l}$, IgA $4.9 \mathrm{~g} / \mathrm{l}, \operatorname{IgG} 16.3 \mathrm{~g} / \mathrm{l}$ (normal $<14.6 \mathrm{~g} / \mathrm{l}$ ). Other laboratory findings were normal. HLA typing: A2, Aw19, B13, B15, Bw4, Bw6, DR4, DR7, DRw53, DQw2, DQw3.

Thirteen days after starting azathioprine $100 \mathrm{mg}$ daily she developed fever $\left(39^{\circ} \mathrm{C}\right)$, nausea, vomiting, and diarrhoea. Blood tests showed raised alkaline phosphatase $(240$ $\mathrm{U} / 1)$ and gamma-glutamyltransferase $(76 \mathrm{U} / 1)$. Blood cells counts were unchanged. Transaminase and amylase were normal. Blood cultures showed no growth. Ultrasonography of the abdomen was normal. Azathioprine was discontinued. Five days later one tablet of azathioprine was given by accident and within two hours diarrhoea and fever $\left(39.5^{\circ} \mathrm{C}\right)$ again occurred. Liver enzymes retumed to normal in two weeks. She was successfully treated with $15 \mathrm{mg}$ methotrexate orally weekly. This drug caused no liver dysfunctions.

Case 3. A 74 year old woman was diagnosed as suffering from seropositive RA since 1984. Besides diclofenac $100 \mathrm{mg}$ daily she had been treated with parenteral gold for one year and D-penicillamine $750 \mathrm{mg}$ daily for 18 months. Both drugs were ineffective. In October 1987 azathioprine $100 \mathrm{mg}$ daily was started because of active RA involving wrists, hands, left shoulder, and jaws. Laboratory findings showed an ESR of $30 \mathrm{~mm} / \mathrm{h}$, C reactive protein $51.0 \mathrm{mg} / \mathrm{l}$ (normal $<6.0 \mathrm{mg} / \mathrm{l}$ ), haemoglobin $125 \mathrm{~g} / \mathrm{l}$. Apart from a diminished renal function (estimated creatinine clearance $60 \mathrm{ml} / \mathrm{min}$ ) and raised $\operatorname{IgA}(4.1$ $\mathrm{g} / \mathrm{l})$ and $\mathrm{IgG}(21.6 \mathrm{~g} / \mathrm{l})$, other laboratory values were normal. HLA typing: A2, A29, B12, B27, Bw4, Bw6, DR4, DRw53, DQw3.

On the 13th day of azathioprine treatment she showed fever $\left(38.5^{\circ} \mathrm{C}\right)$, dry cough, and some nausea. Laboratory studies showed slight leucopenia $\left(3.1 \times 10^{9} / 1\right)$ with normal differential count. A viral infection was suspected and azathioprine was temporarily discontinued. Two weeks later azathioprine was restarted. Within two hours of taking one tablet severe fever $\left(41.5^{\circ} \mathrm{C}\right)$ with chills occurred which necessitated hospital admission. Examination showed no hypotension and no other findings to explain the high fever. Repeated blood tests showed an ESR of $35 \mathrm{~mm} / \mathrm{h}$. Leucocytes, differential count, and liver function tests were normal. Blood cultures showed no growth and a chest radiograph was normal. Two days after admission and discontinuation of azathioprine she was afebrile. Treatment with oral methotrexate $(7.5 \mathrm{mg}$ weekly) had to be discontinued five months later because of stomatitis and dermatitis.

\section{DISCUSSION}

Our finding of azathioprine hypersensitivity reactions in three of 25 (12\%) patients with RA followed up for one year is remarkable. Bell et al. (ARA meeting, Houston, May 1988) have also reported a high percentage of azathioprine hypersensitivity reactions 
$(4 / 17 ; 24 \%)$. The presence of these side effects in larger numbers of patients with RA, our own previous study included, was between $<1 \%$ and $5 \%(1,3,4,5)$.

To our knowledge the triad (severe liver function abnormalities, rash, fever with chills), as shown in patient 1, has been reported only once before in two out of a series of 50 patients with RA (2). Hypersensitivity reactions or hepatotoxicity, or both, due to azathioprine have also been reported in patients with diseases other than RA (6-10). Although a genetic predisposition to azathioprine toxicity is speculative, we found a striking similarity of HLA typing in patients 1 and 2, both having the phenotypes A2, B15, Bw4, Bw6, DR4, DQw2, DQw3. Patient 3 also had these phenotypes except B15 and DQw2. In 171 other patients with RA treated with different drugs we did not find the HLA typing of cases 1 and 2. We could not confirm an association between a low IgA concentration and azathioprine hepatotoxicity (11) because the patients we described all had repeatedly raised IgA concentrations.

Hypersensitivity reactions to azathioprine have been found to occur mostly within two weeks of starting treatment $(2,6)$. That interval was also seen in our three patients.

Hepatotoxicity associated with azathioprine can develop between two weeks and 33 months after starting treatment $(6,8)$, possibly depending on the origin of hepatotoxicity. The mechanisms of azathioprine hepatotoxicity may be threefold-namely (a) allergic (with simultaneous systemic allergic symptoms); (b) direct hepatotoxic [exact mechanism unknown (12)]; (c) blockade of the liver blood outflow at the junction of sinusoids and centrilobular veins, causing peliosis hepatitis (13). Davis et al. have suggested that the imidazole moiety of azathioprine causes the allergic symptoms and the 6-mercaptopurine moiety the liver injury (10). Histologically, the picture of azathioprine hepatotoxicity consists of intrahepatic cholestasis with variable degrees of liver cell necrosis and slight (peri)portal inflammatory reaction. Biochemically, abnormal liver function tests are found, ranging between a cholestatic pattern and increase of transaminase $(6,12)$. Azathioprine hepatotoxicity is mostly a reversible process, but normalization of liver enzymes can take several months (8), as shown in patient 1. For different reasons it seems unlikely that diclofenac had a role in the production of liver dysfunctions in patient 1. Firstly, he had already used that drug for several years without side effects. Secondly, liver function returned to normal (very slowly) while treatment with diclofenac was continuing. Thirdly, the pattem of liver enzyme increase (cholestatic) is unusual for diclofenac hepatotoxicity (14).

Reintroduction of a smaller dose of azathioprine in dose related hepatotoxicity seems justified (9), but rechallenge of azathioprine when there is a suspicion of hypersensitivity can be dangerous and lead to life threatening shock (15-17).

In patient 2 the reintroduction of azathioprine was not our intention but happened accidentally. Retrospectively, the first period of fever and malaise in patient 3 was not recognized as azathioprine toxicity. If there is a compelling reason for reintroducing azathioprine it must be done under very careful clinical observation (17). For completeness we point out that the spectrum of azathioprine hypersensitivity can include more symptoms (18).

In summary, with these three case reports of azathioprine hypersensitivity in patients with RA we draw attention to this serious complication and recommend that liver 
function tests are carried out two weeks after starting azathioprine and thereafter every one to two months.

\section{Addendum}

Very recently we saw a new case of severe azathioprine hypersensitivity in a patient whose clinical picture was similar to that of patient 1.

The patient, a 27 year old man who had had destructive seropositive RA since 1983, was admitted to hospital because of fever $\left(39.2^{\circ} \mathrm{C}\right)$, chills, nausea, cough, and purpura on his legs. He had taken azathioprine $100 \mathrm{mg}$ for 12 days and piroxicam $20 \mathrm{mg}$ daily for several years. Both drugs were discontinued. Laboratory investigation of this severely ill patient disclosed an ESR of $126 \mathrm{~mm} / \mathrm{h}(78 \mathrm{~mm} / \mathrm{h}$ ), (figures in brackets show the values before the start of azathioprine treatment), haemoglobin $101 \mathrm{~g} / 1(127 \mathrm{~g} / \mathrm{l})$, leucocytes $27 \times 10^{9} / 1\left(11.8 \times 10^{9} / 1\right)$ with shift to the left in the differential count, bilirubin total $63 \mu \mathrm{mol} / 1$, direct $46 \mu \mathrm{mol} / 1$, alkaline phosphatase $422 \mathrm{U} / 1(77 \mathrm{U} / \mathrm{l})$, gamma-glutamyltransferase $73 \mathrm{U} / 1$, ALT $87 \mathrm{U} / 1$ (8 U/I), AST $32 \mathrm{U} / \mathrm{l}$ (11 U/l). Chest radiograph was normal. Blood cultures showed no growth. All serological tests (see patient 1) were negative. Because all liver enzymes rose further in three weeks (alkaline phosphatase 800 U/l, gamma-glutamyltransferase $175 \mathrm{U} / 1$, ALT $192 \mathrm{U} / 1$, AST $63 \mathrm{U} / \mathrm{l}$ ) a liver biopsy was performed, which disclosed a moderate portal infiltration of eosinophil leucocytes around small bile canaliculi (without bile stasis). Sporadic necrotic liver cells were present. A skin biopsy showed aspecific perivascular inflammation. Six weeks after admission this patient is still in hospital (May 1989) and liver enzymes are still greatly raised (alkaline phosphatase $900 \mathrm{U} / 1$, gamma-glutamyltransferase $254 \mathrm{U} / 1$, ALT $148 \mathrm{U} / \mathrm{l}$ ). HLA typing: Aw19, B15, B40, Bw6, DR4, DQw3.

\section{Acknowledgment}

We are grateful to Dr M Kruijsen (Ziekenhuis Ziekenzorg, Enschede, The Netherlands) for allowing us to study his patients, and we wish to thank Mrs. Marion Janssen for her excellent secretarial help.

\section{REFERENCES}

1. Whisnant JK, Pelky J. Rheumatoid arthritis: treatment with azathioprine [Imuran(R)]. Clinical side effects and laboratory abnormalities. Ann Rheum Dis 1982; 41 (suppl): 44-7.

2. Stollenwerk R, Schilling F. Imurek-Fieber. Verh Dtsch Ges Rheumatol 1980; 6: 473-4.

3. Speerstra F, Boerbooms AMTh, van de Putte LBA, van Beusekom HJ, Kruijsen MWM, Vandenbroucke JP. Side effects of azathioprine treatment in rheumatoid arthritis: analysis of 10 years of experience. Ann Rheum Dis 1982; 41: 37-9.

4. Paulus HE, Williams HJ, Ward JR, et al. Azathioprine versus D-penicillamine in rheumatoid arthritis patients who have been treated unsuccessfully with gold. Arthritis Rheum 1984; 27: $721-7$.

5. Handy $\mathrm{H}$, McKendry RJR, Mierins E, Liver JA. Low-dose methotrexate compared with azathioprine in the treatment of rheumatoid arthritis. A twenty-four week controlled 
clinical trial. Arthritis Rheum 1987; 30: 361-8.

6. Kissel JT, Levy RJ, Mendell JR, Griggs RC. Azathioprine toxicity in neuromuscular diseases. Neurology 1986; 336: 35-9.

7. Singleton JW, Law DH, Kelly ML, Mekhjian HS, Sturdevant RAL. National cooperative Crohn's disease study: adverse reactions to study drugs. Gastroenterology 1979; 77: 87082.

8. Iselin $\mathbf{H}$, Knoblauch $\mathbf{M}$, Binswanger $\mathbf{K}$, et al. Azathioprin-induzierte intrahepatische cholestase. Schweiz Med Wochenschr 1976; 106: 320-1.

9. Ware AJ, Luby JP, Hollinger B, et al. Etiology of liver disease in renal transplant patients. Ann Intern Med 1979; 91: 364-71.

10. Davis M, Eddlestone ALWF, Williams R. Hypersensitivity and jaundice due to azathioprine. Postgrad Med J 1980; 56: 274-5.

11. Harvey C, Dixon JS, Bird HA. Serum IgA concentration and hepatotoxicity in theumatoid arthritis treated with azathioprine. Br Med J 1983; 287: 534.

12. Menard DB, Gisselbrecht C, Marty M, Reyes F, Dhumeaux D. Antineoplastic agents and the liver. Gastroenterology 1980; 78: 142-64.

13. Degott C, Rueff B, Kreis H, Duboust A, Potet F, Benkamou JP. Peliosis hepatitis in recipients of renal transplants. Gut 1978; 19: 748-53.

14. Paulus HE. FDA arthritis advisory committee meeting: serious gastrointestinal toxicity of non-steroidal anti-inflammatory drugs; drug-containing renal and biliary stones; diclofenac and carprofen approved. Arthritis Rheum 1988; 31: 1450-1.

15. Cunningham T, Barraclough D, Murdin K. Azathioprine-induced shock. Br Med J 1981; 283: 823-4.

16. Keystone EC, Schabas R. Hypotension with oliguria: a side effect of azathioprine. Arthritis Rheum 1981; 24: 1453-4.

17. Rosenthal E. Azathioprine shock. Postgrad Med J 1986; 62: 677-8.

18. Saway PA, Heck LW, Bonner JR, Kerklin JK. Azathioprine hypersensitivity. Case report and review of the literature. Am J Med 1988; 84: 960-4. 
Chapter 9.3

\section{PANCYTOPENIA AND METHOTREXATE WITH TRIMETHOPRIM- SULFAMETHOXAZOLE}

M.E.C. Jeurissen, MD, A.M.Th. Boerbooms, MD, PhD, L.B.A. van de Putte, MD, $\mathrm{PhD}$

Department of Rheumatology University Hospital Nijmegen, 6525 GA Nijmegen, The Netherlands

Ann Intern Med 1989; 111: 261 (Reproduced with permission) 



\section{To the Editor:}

Kozarek and colleagues (1) found a dramatic clinical improvement in patients treated with methotrexate who had refractory Crohn colitis and an incomplete remission of chronic ulcerative colitis. Of 21 patients, 14 were also receiving either sulfasalazine or metronidazole (exact number of patients not mentioned).

The risk of bone marrow suppression is increased when other antifolate drugs (derivatives of sulfonamides, trimethoprim) are used simultaneously with methotrexate. Besides additive folate antagonism, other pharmacologic mechanisms, such as competition with tubular secretion and displacement from albumin binding sites, play an important role in interactions of sulfonamides and methotrexate. Moreover, it was shown that sulfasalazine inhibits the hydrolysis of polyglutamyl folate and the intestinal transport of folate in patients with ulcerative colitis (2). Pancytopenia due to the combined use of methotrexate and trimethoprim-sulfamethoxazole has been reported in two patients with rheumatoid arthritis $(3,4)$. We report two additional cases of this severe side effect.

In case 1, an 81-year-old woman had refractory rheumatoid arthritis and impaired renal function (creatinine, $166 \mu \mathrm{mol} / \mathrm{l}$ ) and was treated with methotrexate, $5 \mathrm{mg}$ weekly for 6 weeks. Cystitis (Escherichia coli) was treated with trimethoprim, $300 \mathrm{mg}$ daily. One week after starting trimethoprim, bone marrow suppression developed (leukocytes, $1.9 \mathrm{x}$ $10^{9} / 1$; platelets, $15 \times 10^{9} / \mathrm{l}$; hemoglobin, $\left.6.3 \mathrm{mmol} / \mathrm{l}\right)$. Both methotrexate and trimethoprim were discontinued. Blood cell counts retumed to normal in 2 weeks. One month after discharge she died of severe bronchopneumonia (determined at autopsy).

In case 2, a 75-year-old woman with refractory rheumatoid arthritis and impaired renal function (estimated creatinine clearance, $40 \mathrm{ml} / \mathrm{min}$ ) was receiving methotrexate, $5 \mathrm{mg}$ weekly. A recurrent cystitis was treated with trimethoprim-sulfamethoxazole. Shortly after beginning trimethoprim-sulfamethoxazole, bone marrow suppression developed (hemoglobin, $5.6 \mathrm{mmol} / 1$; leukocytes, $1.6 \times 10^{9} / 1$; platelets, $23 \times 10^{9} / 1$ ). A bone marrow biopsy specimen showed hypocellularity. Both drugs were discontinued, and therapy with leucovorin was begun; she recovered in several weeks.

These two patients were not treated with the combination of sulfasalazine and methotrexate; however, other antifolate drugs were used in conjunction with methotrexate. Additive folate antagonism, independent of which antifolate drug was used simultaneously with methotrexate, seemed to play a central role in inducing bone marrow suppression in these patients. We do not recommend prescribing other drugs with antifolate action simultaneously with methotrexate. The toxicity of and the possibility of adverse drug interactions with methotrexate are increased in the presence of other risk factors such as old age, hypalbuminemia, impaired renal function, and decreased bone marrow reserve (5).

\section{Acknowledgment}

We thank Drs.J.Rasker, W.Hissink Muller, and J.Haverman for allowing us access to their patients. 


\section{REFERENCES}

1. Kozarek RA, Patterson DJ, Gelfand MD, Botoman VA, Ball TJ, Wilsh KR. Methotrexate induces clinical and histological remission in patients with refractory inflammatory bowel disease. Ann Intern Med. 1989; 110: 353-6

2. Halstead $\mathbf{C H}$, Ghandi G, Tamura T. Sulfasalazine inhibits the absorption of folates in ulcerative colitis. N Engl J Med. 1981; 305: 1513-7.

3. Maricic M, Davis M, Gall EP. Megaloblastic pancytopenia in a patient receiving concurrent methotrexate and trimethoprim-sulfamethoxazole treatment. Arthritis Rheum. 1986; 29: 133-5.

4. Thomas MH, Gutterman LA. Methotrexate toxicity in a patient receiving trimethoprimsulfamethoxazole. J Rheumatol. 1986; 13:440-1.

5. MacKinnon SK, Starkebaum G, Willkens RF. Pancytopenia associated with low pulse methotrexate in the treatment of theumatoid arthritis. Arthritis Rheum. 1985; 28: 119-26. 
Chapter 9.4

\section{ERUPTION OF NODULOSIS AND VASCULITIS DURING METHOTREXATE THERAPY FOR RHEUMATOID ARTHRITIS}

M.E.C. Jeurissen, A.M.Th. Boerbooms. L.B.A. van de Putte

Department of Rheumatology, University Hospital Nijmegen, P.O. Box 9101, $6500 \mathrm{HB}$ Nijmegen, The Netherlands

Clin Rheumatol 1989; 8: $418-419$ (Reproduced with permission) 

Figure 1. Vasculitic lesions on the big toe (A). Subcutaneous nodules (arrows) on the thoracolumbal spine (B).

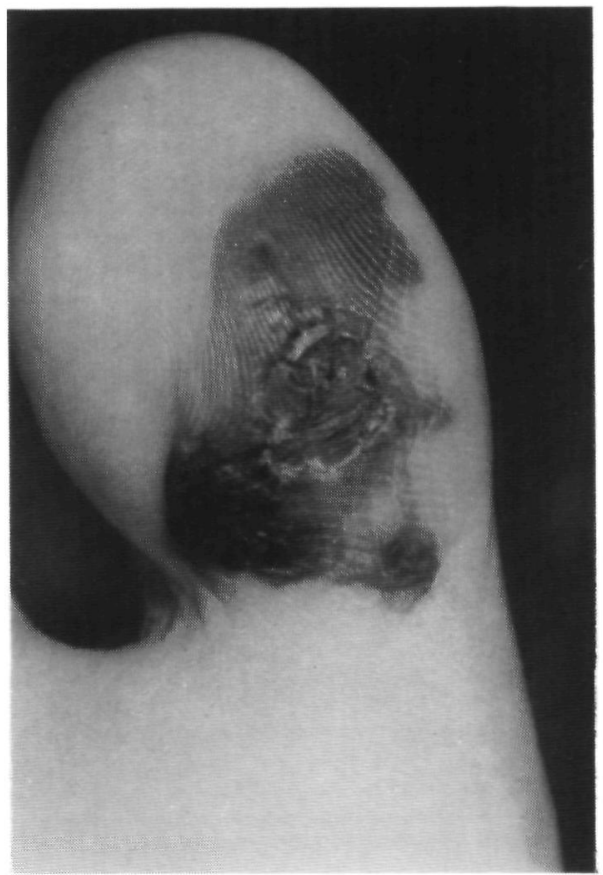

A

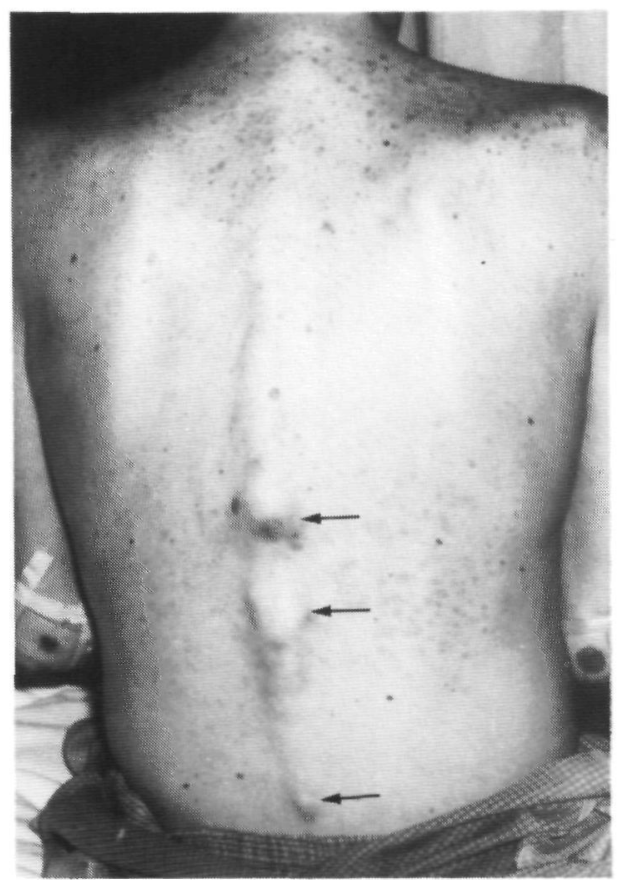

B

\section{To the Editor:}

Recently, the development of new subcutaneous nodules in three patients with rheumatoid arthritis (RA), treated with methotrexate (MTX) was described (1). This adverse reaction of MTX has also been reported in two other studies $(2,3)$. In our clinic we also observed extensive and severe eruption of new nodules with an extraordinary localization, i.e the spinal column and the soles of the feet. Moreover, vasculitis lesions appeared on the feet. The patient concerned, a 51-year-old man with seropositive RA, was treated weekly with MTX $7.5 \mathrm{mg}$ orally. Previous therapy with hydroxychloroquine and parenteral gold was ineffective. At the start of MTX therapy he had some nodules on his elbows, left-sided pleural effusion, but no vasculitis skin lesions. Laboratory investigation revealed an erythrocyte sedimentation rate (ESR) of $100 \mathrm{~mm} / \mathrm{hr}, \mathrm{C}$ reactive 
protein (CRP) $81.0 \mathrm{mg} / \mathrm{l}$ (normal $<6.0 \mathrm{mg} / \mathrm{l}$ ) and hemoglobin of $5.7 \mathrm{mmol} / \mathrm{l}$. Other laboratory values (C3 and $\mathrm{C} 4$ included) were normal, except elevation of all immunoglobulin (Igg) levels. Antinuclear antibody was strongly positive and the HLA typing revealed the DR4 phenotype.

Two months after starting MTX therapy, new nodules developed on his forearms, metacarpophalangeal joints and eyebrows. One month later nodules appeared on his knees, buttocks and dorsum of his feet. When inflamed nodules developed along his spinal column and on the soles of his feet together with vasculitic lesions (Fig. 1), he was unable to lay down on his back or to walk. Hospital admission followed and MTX was discontinued. After discontinuation of MTX, the nodules gradually regressed in about one month. However, the RA relapsed and therapy with azathioprine was started. In contrast with the observation of Segal et al. (1), the CRP level remained high (81.0 $\mathrm{mg} / \mathrm{l})$ during MTX therapy. The levels of Igg's did not change during MTX therapy despite the good clinical response of his arthritis to MTX. In other RA patients with a good clinical response to MTX, we found a significant decrease of Igg levels (4).

In summary, we have reported on severe eruption of new nodules and vasculitic lesions, localized on extraordinary sites in a RA patient treated with low-dose MTX therapy. Diametrically opposed to the induction of new nodules and vasculitis (5) by MTX, is the beneficial clinical effect of MTX in some patients with rheumatoid (vasculitic) ulcers $(6,7)$ and in patients with systemic vasculitis like polyarteritis nodosa $(8,9)$. Whether there are (immunohistological) differences between nodules and/or vasculitis (skin) lesions developed in the course of RA and those induced by MTX, has to be evaluated.

\section{REFERENCES}

1. Segal R, Caspi D, Tishler M, Fishel B, Yaron M. Accelerated nodulosis and vasculitis during methotrexate therapy for rheumatoid arthritis. Arthritis Rheum 1988; 31 : 11821185 .

2. Kremer J.M, Lee J.K. The safety and efficacy of the use of methotrexate in long-term therapy for rheumatoid arthritis. Arthritis Rheum 1986; 29: 822-831.

3. Weinblatt M.E, Trentham D.E, Fraser P.A, Holdsworth D.E, Falchuk K.R, Weissman B.N, Coblyn J.S. Long-term prospective trial of low-dose methotrexate in rheumatoid arthritis. Arthritis Rheum 1988; 31: 167-175.

4. Boerbooms A.M.Th, Jeurissen M.E.C, Westgeest A.A.A, Theunisse H, van de Putte L.B.A. Methotrexate in refractory theumatoid arthritis. Clin Rheumatol 1988; 7: 249-256.

5. Marks C.R, Willkens R.F, Wilske K.R, Brown P.B. Small-vessel vasculitis and methotrexate. Ann Intern Med 1984; 100: 916.

6. Tiliakos $\mathbf{N}$. Pulse methotrexate therapy for intractable rheumatoid cutaneous ulcers (RCU). Arthritis Rheum 1985 (suppl), S37, 140.

7. Espinoza L.R, Espinoza G.G, Vasey F.B, Germain B.F. Oral methotrexate therapy for chronic rheumatoid arthritis ulceration. J Am Acad Dermatol 1986; 15: 508-512.

8. Tannenbaum H. Combined therapy with methotrexate and prednison in polyarteritis nodosa. Canad Med Assoc 1980; 123: 893-894.

9. Mitchell M.S, Gifford R.H, Bertino J.R, Kenney J.D, Malawista S.E. The treatment of disseminated vasculitis with methotrexate. Inflammation 1976; 1: 285- 295. 
Chapter 10

\section{SUMMARY AND CONCLUSIONS}



The main objective of this thesis was to elucidate the place of low-dose methotrexate (MTX) in the treatment of rheumatoid arthritis (RA) patients with emphasis on clinical aspects. To this purpose a comparison was made with azathioprine (AZA), the other cytotoxic drug frequently used in the treatment of $R A$. The results of a double-blind trial of AZA versus MTX in RA are presented and discussed. The clinical results (Chapter 6), the influence on radiologic progression (Chapter 7) and the results of pulmonary function tests (Chapter 8) will be reviewed successively.

In Chapter 1 the pathogenesis of RA, indications for the use of azathioprine and methotrexate in RA, and the mechanisms of action of these drugs are summarized.

Rheumatoid Arthritis is a chronic systemic and articular disorder of unknown origin. The main feature of RA is symmetric polyarthritis of hands and feet. The course of the disease is variable and often unpredictable. In about $10 \%$ of patients the disease runs a progressive course, characterized by destructive polyarthritis and frequently by extraarticular manifestations.

The sequence of pathological processes in RA, divided into five stages, starts with presentation of the unknown antigen to T-cells and ends with invasion and destruction of cartilage, intra-articular ligaments and subchondral bone. T-lymphocytes play an important part in the complex process of immune and inflammatory events in RA.

Indications for use of cytotoxic, immunoregulatory drugs such as AZA and MTX are presence of active polyarthritis despite combined treatment with first-line antirheumatic drugs (non-steroidal anti-inflammatory drugs = NSAIDs) and second-line antirheumatic drugs (hydroxychloroquine, parenteral gold, salazopyrine or D-penicillamine). Other indications are development of severe radiologic progression and presence of extra-articular manifestations such as vasculitis.

Despite extensive research the exact mechanism of action of AZA and MTX is still unclear. Interesting findings from in vivo and in vitro animal- and human studies have shed some light upon possible mechanisms of action of, especially, low-dose MTX in RA. Anti-inflammatory, subtle immunomodulating and antiproliferative effects may play a part (Chapter 1).

Chapter 2 and 3 provide general information on azathioprine and methotrexate. Azathioprine is quickly metabolized to 6-Mercaptopurine (6-MP). Both drugs are purine analogues and inhibit DNA and RNA synthesis after conversion to their ribonucleotides. The metabolism of AZA (and 6-MP) follows three important enzymatic routes of which the conversion by hypoxanthine guanine phosphoribosyl transferase (HGPRT) is the major one. Inherited low thiopurine methyl transferase (TPMT) activity constitutes a major risk for development of AZA induced myelosuppression. Concurrent use of AZA and allopurinol, a known xanthine oxidase inhibitor, may also led to myelo-suppression.

The usual dosage of AZA in the treatment of $R A$ ranges from $1.5 \mathrm{mg} / \mathrm{kg}$ to $2.5 \mathrm{mg} / \mathrm{kg}$ daily. Adequate contraception is recommended when the drug is prescribed. Whether AZA causes an excess of malignancies in RA is still unclear.

Double-blind studies of AZA versus other second-line antirheumatic drugs have not revealed significant intergroup differences regarding clinical effect or adverse reactions. 
Gastrointestinal side effects and leucopenia are the most frequent adverse reactions to AZA. Less frequent side effects are hepatotoxicity, hypersensitivity reactions, thrombocytopenia, and pancytopenia.

Methotrexate is an antagonist of folate dependent enzymes of which dihydrofolate reductase (DHFR) is the most important target enzyme. Folate dependent enzymes are involved in DNA and RNA synthesis. MTX is converted mainly to MTX-polyglutamates. Low-dose MTX therapy $(7.5-15 \mathrm{mg} /$ week) in RA patients does not cause progressive accumulation of MTX-polyglutamates in the liver. Renal excretion is the major route of MTX elimination. Patients with decreased renal function (renal clearance $<50 \mathrm{ml} / \mathrm{min}$ ) have an increased risk of adverse reactions to MTX. MTX synovial fluid levels are equal or higher than MTX serum levels. Concurrent use of nonsteroidal anti-inflammatory drugs and low-dose MTX in RA, rarely causes serious drug interactions. Severe myelosuppression is possible when MTX and other antifolate drugs such as trimethoprim and trimethoprim-sulfamethoxazole (co-trimoxazole) are used concurrently.

Leucovorin is used as a 'rescue therapy' in patients with (severe) toxicity of MTX. Folic acid ( $1 \mathrm{mg} /$ day) can significantly lower MTX toxicity without affecting the clinical efficacy of MTX in RA. Since MTX has teratogenic properties, adequate contraception during treatment with the drug is absolutely indicated. There is no evidence to assume that MTX is a carcinogenic drug.

In a double-blind trial MTX was more effective and less toxic than oral gold. In other trials no significant differences were demonstrated between MTX and parenteral gold and between MTX and AZA.

The most frequent adverse reactions of MTX are elevated liver enzymes and gastrointestinal side effects. Less frequent adverse reactions are stomatitis, hematological- and pulmonary (pneumonitis) side effects. Since there is no relevant hepatotoxicity after a cumulative dosage of 1.5-2.0 $\mathrm{g}$ MTX in RA patients, there is much debate about the need for post MTX liver biopsies, especially in low risk patients. The percentage of patients who were still on MTX therapy after 5 to 6 years $( \pm 50 \%)$, is much higher than the percentage found for other second-line antirheumatic drugs (less than 20\%).

Chapter 4 reviews the clinical use of MTX therapy in connective tissue diseases. Additional data on pharmacology of MTX, its adverse reactions, risk factors, drug interactions and recommendations for drug monitoring are presented.

Four placebo controlled trials of MTX in RA have demonstrated that MTX had a superior clinical effect. The clinical experience with MTX in polymyositis, dermatomyositis, systemic lupus erythematosus, scleroderma, and vasculitis, suggest that MTX is an effective drug in these connective tissue diseases. Mechanisms by which other drugs can increase the toxicity of MTX are mainly through competition with renal tubular secretion, displacement of albumin binding sites and additive folate antagonism. Alcohol abuse is the major risk factor for MTX-induced hepatotoxicity. Impaired renal function, decreased serum albumin and concurrent use of other antifolate drugs are risk factors for the development of hematological adverse reactions to MTX.

The following scheme for drug monitoring during MTX treatment is proposed: the first 
4 weeks hemoglobin, leucocytes (with differential count), and platelets weekly, renal and liver function tests biweekly; thereafter all aforementioned blood tests monthly until six months after start of therapy; after 6 months blood tests every 1-2 months. When an increased dosage of MTX is prescribed, drug monitoring should be intensified for several months. Baseline chest radiographs and pulmonary function tests (spirometry and $\mathrm{CO}$ diffusion) should be considered seriously.

Chapter 5 describes the results of an open 12 month study of 16 patients with active RA refractory to hydroxychloroquine, gold thioglucose, D-penicillamine and azathioprine. Patients received $7.5 \mathrm{mg}$ MTX weekly and depending on their clinical effect after 8 weeks, $15 \mathrm{mg}$ MTX weekly. All patients had used NSAIDs and 8 patients also used prednisone ( $\leq 10 \mathrm{mg}$ daily) before the study.

Clinical and laboratory assessments were made monthly during the first 6 months and thereafter every 2 months. Two of the 16 patients were excluded from analysis because of side effects (one patient severe diarrhoea, one patient depression). Fourteen patients completed 6 months and 12 patients completed 12 months of therapy. Two of 14 patients discontinued MTX after 6 months because of inefficacy. After 6 months there was significant $(P \leq 0.05)$ improvement of 5 clinical variables: morning stiffness, tender joints, Ritchie index, swollen joints, and pain score. Furthermore ESR, C-reactive protein, and IgA, IgG, IgM improved significantly. No significant change in mean rheumatoid factor was found. The clinical improvement started as early as after 1 month and increased up to 6 months. Between 6 and 12 months clinical and laboratory variables only changed minimally (plateau phase). At 12 months all articular indices had improved by $50 \%$ compared with baseline values. Gastrointestinal side effects (31\%) and elevated liver enzymes (25\%) were the commonest adverse reactions to MTX in this study. All these side effects disappeared after reduction of the dose of MTX.

The general conclusion from this study was that MTX was an effective second-line drug in refractory $R A$.

In Chapter 6 the results of a double-blind randomized 48 week trial are described and discussed. In this trial azathioprine was compared with methotrexate in 64 patients with active RA refractory to at least parenteral gold, D-penicillamine or both drugs. Patients were randomly assigned to receive $7.5 \mathrm{mg}$ MTX weekly or $100 \mathrm{mg}$ AZA daily (double dummy). Depending on the clinical effect after 8 weeks, the dosage was increased to 15 $\mathrm{mg} \mathrm{MTX}$ or $150 \mathrm{mg} \mathrm{AZA}$. The dosages of NSAIDs and prednisone ( $\leq 10 \mathrm{mg}$ daily) were held stable for at least 4 weeks before study entry and throughout the study.

Clinical results were analyzed for patients who continued on the same drug for 24 and 48 weeks and also for an intention-to-treat approach, that is, independently of whether patients switched to other second-line drugs. Baseline values compared with 24 and 48 weeks values were calculated. For the period 0-24 weeks, 4 weekly data were utilized in an area under the curve (AUC) analysis. Apart from the change in separate clinical and laboratory variables, the change in a validated composed index of 4 variables (disease activity score $=$ DAS) was calculated.

Except for gender $(P=0.01)$ patients on AZA $(n=33)$ and MTX $(n=31)$ showed no 
significant differences in demographic and clinical variables at the start of the study. Comparison of 24-week values with baseline values revealed significant $(P<0.05)$ improvement in 12 of 13 clinical and laboratory variables in the MTX group and 6 of 13 in the AZA group. Comparison between the two same drug groups at 24 weeks showed significant improvement of swollen joints, pain score, ESR, CRP, hemoglobin, platelets and DAS in favor of the MTX treated patients (AUC analysis, P<0.04). An intention-to-treat analysis at 24 weeks showed equal clinical results as shown in the same drug groups, except for swollen joints. After 48 weeks no significant differences in clinical and laboratory variables were found between the two groups. However, statistically significant results in the same drug groups at 48 weeks could be missed because of the small number of AZA patients (12 AZA vs 24 MTX patients).

In the period between 8 and 24 weeks, two to three times more MTX than AZA patients had significant improvement of the DAS. After 48 weeks half of the AZA and three-quarters of the MTX patients had significant improvement of the DAS. Significantly more patients on AZA withdrew from the study due to severe side effects (13 AZA vs 2 MTX). Severe adverse reactions to AZA comprised gastrointestinal complaints (5), cholestatic liver dysfunction (2), hypersensitivity (3), and hematological (2) side effects. Dermatitis and severe nodulosis necessitated discontinuation of MTX therapy in two patients.

In conclusion, this double-blind trial demonstrated clinical superiority of MTX to AZA in RA patients. The earlier, more pronounced, and more sustained clinical improvement after one year of MTX therapy was accompanied by a lower rate of serious adverse reactions.

Chapter 7 describes the influence of methotrexate and azathioprine on the radiologic progression in RA. This influence was investigated in the same patient groups as mentioned in Chapter 6. Radiographs of hands, wrists and feet were taken at baseline and after 24 and 48 weeks. Radiographs of the hands and wrists were scored according to the modified method of Sharp. Since there was hardly any variation $(R=0.98)$ in either the intra- or the interobserver measurements for erosions and joint space narrowing, all radiographs of the trial were scored by one experienced rheumatologist, who was unaware of the clinical findings and drugs the patients used. Results of radiologic scores were analyzed for patients who completed 24 and 48 weeks of the same therapy and also in an intention-to-treat approach. Initial radiologic scores (erosion score and total joint score, i.e. score for erosion plus score for joint space narrowing) were comparable in the two treatment groups. After including possible confounders (gender, disease duration etc) all radio-graphic scores changed at most 0.2 (multiple regression analysis). Therefore unadjusted estimates were presented.

Patients who completed 24 and 48 weeks of the same drug, showed more new erosions when treated with AZA than with MTX. This difference was significant after 48 weeks. The total radiologic score at 24 and 48 weeks also showed less progression in the MTX group, but the difference was not significant. The small number of patients who completed 48 weeks of AZA therapy, however, limited the statistical power. After an intention-to-treat analysis at 24 and 48 weeks, significantly fewer new erosions and less 
change in total radiologic score were found in favor of the patients initially treated with MTX. Radiologic stabilization after 48 weeks was present in 10\% of the AZA group and in 29\% of the MTX group.

In summary, this study shows significantly less radiologic progression in RA patients who started on MTX compared with patients who started on AZA. The favorable radiologic results of MTX probably reflect the earlier response and more pronounced clinical effect of MTX. These data indicate also that even in longstanding erosive RA, further radiologic progression may be influenced by antirheumatic second-line drugs.

In Chapter 8 the question was investigated whether periodic pulmonary function tests and chest radiographs were useful for detecting MTX-induced pulmonary toxicity in RA. It was also investigated whether pre-existent pulmonary abnormalities were a risk factor for development of MTX pneumonitis. The patients on AZA therapy served as a control group. A question of secondary importance was whether there was an association between the presence of keratoconjunctivitis in RA and the presence of small airways disease, detected by flow volume curves.

Clinical findings in the two patient groups were identical to the data mentioned in Chapter 6. Pulmonary function tests (spirometry, flow volume curves, CO diffusion, lung compliance) and chest $X$-rays were performed at study entry, after 24 weeks and after 2 years.

Baseline pulmonary function tests, performed in 52 patients (27 AZA; 25 MTX patients) were not significantly different between the two groups and showed abnormal results of one or more function tests in 15 to $50 \%$ of all patients. Thirty-seven percent of patients had decreased $\mathrm{CO}$ diffusion. Five patients had radiographic signs of lung fibrosis, one patient had pleural effusion and one patient had pulmonary nodules. At the time of data collection, 35 patients (18 on AZA; 17 on MTX) had completed 2 years of follow-up. After 24 weeks and 2 years there were no significant changes in mean results of pulmonary function tests within the two groups nor differences between both groups. When patients were divided into those with and without decreased (comparison with predicted values) pulmonary function tests, no differences at 24 weeks were found, either, between patients treated with AZA or MTX.

Patients with pre-existent lung abnormality did not develop MTX-induced pneumonitis. Nine patients (6 AZA; 3 MTX patients) had keratoconjunctivitis sicca (KCS). An association between KCS and presence of small airways disease and HLA DR4 was confirmed. All but one patient in this subgroup of RA had subcutaneous nodules. Small airways disease is considered to be one of the extra-articular features of RA and part of a generalized exocrinopathy.

In conclusion, this study has demonstrated that pulmonary function tests and chest Xrays do not change after 24 weeks and 2 years of therapy with AZA or MTX in RA. Patients with pre-existent lung abnormalities did not develop MTX-induced pneumonitis. In view of the prevalence of MTX-induced pulmonary toxicity, baseline pulmonary function tests (spirometry, CO diffusion) is advisable. However, the results of this study suggest no need for periodic pulmonary function tests and chest radiographs during MTX therapy in RA. Long-term prospective studies of more patients are necessary for definite 
conclusions.

In Chapter 9 four rare, but potentially dangerous side effects of AZA and MTX are described. Pancytopenia induced by AZA occurred in one patient within three weeks after starting the trial. Rapid fall of all blood cells, mainly platelets, necessitated hospitalization. A bone marrow biopsy showed hypocellularity and absent megakaryocytes. Because platelet counts fell further $\left(4 \times 10^{\circ} / 1\right)$, transfusion with platelets was necessary. In another patient (not a trial patient) pancytopenia developed due to the simultaneous use of allopurinol and AZA.

In a second article the case studies of three trial patients were described in whom the following adverse reactions to AZA developed within two weeks after starting AZA: patient one showed fever with chills, rash, and severe cholestatic liver dysfunction; the second patient showed fever, nausea, diarrhoea, and liver dysfunction; the third patient had very high fever and severe chills. In the first patient raised liver enzymes persisted until seven months after discontinuation of AZA.

In a third article eruption of subcutaneous nodules and vasculitis during MTX therapy were described. Before MTX therapy, the patient concerned had only nodules at his elbows. MTX therapy was effective for his polyarthritis. However, from the third month of MTX therapy, multiple new nodules developed on extraordinary sites such as knees, along the spinal column, eyebrows etc. Later on inflamed nodules developed and vasculitic lesions were found on the soles of his feet, necessitating hospital admission. After discontinuation of MTX, the nodules regressed within 4 weeks. Pancytopenia due to the combined use of methotrexate and trimethoprim-sulfamethoxazole is reported in a fourth article.

General conclusions from this thesis are:

- Methotrexate is effective in refractory RA, i.e. in RA patients with unresponsiveness to four other second-line drugs: hydroxychloroquine, parenteral gold, D-penicillamine, and azathioprine

- Methotrexate has a superior clinical effect compared with azathioprine in RA patients refractory to parenteral gold, D-penicillamine or both drugs

- The clinical effect of methotrexate starts earlier than that of azathioprine

- Methotrexate causes fewer severe adverse reactions than azathioprine

- RA patients who start on methotrexate therapy show significantly less radiologic progression than patients who start on azathioprine therapy

- Pulmonary function tests did not change during therapy with either methotrexate or azathioprine in RA

- Pre-existent lung abnormalities are no contraindication to MTX therapy in RA

- In view of its superior clinical effect and its disease modifying effect methotrexate is preferable to azathioprine in rheumatoid arthritis. 
Chapter 11

SAMENVATTING 

De voomaamste doelstelling van dit proefschrift was onderzoek naar de plaats van lage dosis methotrexaat (MTX) bij de behandeling van emstige Reumatoide Artritis (RA). Om dit te onderzoeken werd een studie opgezet, waarin MTX vergeleken werd met azathioprine (AZA), een ander cytotoxisch medicament, dat regelmatig gebruikt wordt bij de behandeling van RA.

In de Hoofdstukken 6, 7, en 8 komen achtereenvolgens de klinische resultaten van dit onderzoek, de röntgenologische gegevens, en de bevindingen van longfunctie-onderzoek tijdens die studie aan bod.

In Hoofdstuk 1 worden de criteria en de ontstaanswijze van RA beschreven om vervolgens in te gaan op de indicaties voor het gebruik van cytotoxische geneesmiddelen bij RA en het werkingsmechanisme te bespreken van AZA en MTX. De Hooldstukken 2 en 3 bevatten algemene en meer gedetailleerde informatie over respectievelijk AZA en MTX. Beschreven en belicht worden o.a de farmacologie en -kinetiek, de wisselwerking met andere medicamenten, de toepassing in gecontrolcerde studies bij patiënten met RA op korte- en lange termijn, bijwerkingen enzovoorts. In Hoofdstuk 4 wordt de klinische toepassing van MTX bij collageenziekten samengevat, naast aanvullende gegevens over farmacologie, mechanismen van geneesmiddeleninteracties (tussen MTX en andere medicamenten) en bijwerkingen van MTX. In Hoofdstuk 5 worden de resultaten van een open studie van MTX bij RA belicht.

Terugkerend naar Hoofdstuk 1 wordt beschreven dat Reumatoide Artritis een chronische ziekte is met onbekende oorzaak, gekenmerkt door symmetrische gewrichtsontstekingen (=polyartritis) in vooral handen, polsen en voeten, en minder frequent in ellebogen, knieën en schouders. In 1987 zijn de criteria voor de classificatie van RA herzien. Een patiënt voldoet aan de diagnose RA, indien tenminste 4 van 7 criteria gedurende tenminste 6 weken aanwezig zijn. Deze criteria omvatten: ochtendstijfheid langer dan 1 uur, artritis in 3 of meer gewrichten, artritis in handen, symmetrische artritis, aanwezigheid van reumanoduli, aanwezigheid van reumafactoren in het serum, karakteristieke röntgenologische afwijkingen (o.a erosies).

RA komt 2 à 3 maal vaker voor bij vrouwen dan bij mannen en treft ongeveer 1 à $2 \%$ van de bevolking. Het verloop van de zieite is veelal onvoorspelbaar en wisselend, waarbij opvlammingen van de ziekte worden afgewisseld door rustige perioden. Bij een klein percentage van de patiënten $( \pm 10 \%)$ verloopt de ziekte ernstig progressief. Een dergelijk progressief ziektebeeld wordt gekenmerkt door een ernstige, deformerende en destructieve polyartritis vaak in combinatie met extra-articulaire verschijnselen zoals vasculitis. Vooral voor deze laatste groep patiënten is adequate en krachtige (medicamenteuze) therapie aangewezen.

Het pathologisch proces van RA, grofweg ingedeeld in 5 stadia, begint met de "presentatie" van een onbekend antigeen aan de T-lymfocyt en eindigt met invasie en destructie van kraakbeen, intra-articulaire ligamenten en subchondraal bot. De T-cellen spelen een belangrijke rol in het complexe ontstekingsproces van RA.

Eén van de indicaties voor het gebruik van cytotoxische medicamenten als AZA en MTX, is de aanwezigheid van persisterende polyartritis ondanks behandeling met eerstelijns antireumatica [=niet steroidale anti-inflammatoire middelen (NSAIDs)] in 
combinatie met tweedelijns antireumatica als hydroxychloroquine, oraal goud, salazopyrine, parenteraal goud of D-penicillamine. Andere indicaties zijn emstige radiologische progressie en de aanwezigheid van extra-articulaire manifestaties.

Hoofdstuk 2 bevat gegevens over azathioprine. De eerste stap in het metaboliseringsproces van AZA, is de snelle omzetting naar 6-Mercaptopurine (6-MP). Beide geneesmiddelen zijn purine analoga en remmen de DNA en RNA synthese. De precieze werking van AZA bij RA is onbekend. Vergeleken met placebo is er een bewezen klinisch antireumatisch effect. Studies warin AZA vergeleken is met andere tweede-lijns antireumatica, laten geen verschillen zien noch wat betreft het klinisch effect bij RA noch wat betreft het optreden van bijwerkingen.

$\mathrm{Na}$ de snelle thiolysis (in lever en erythrocyten) van AZA naar 6-MP, vindt verdere omzetting van AZA via drie enzymatische wegen plaats. De route via het enzym hypoxanthine guanine phosphoribosyl transferase (HGPRT) is hiervan de belangrijkste. Patiēnten met een (genetisch bepaald) laag gehalte aan het enzym thiopurine methyltransferase (TPMT) en die behandeld worden met AZA, hebben een potentieel verhoogde kans op beenmergschade. De gelijktijdige toepassing van allopurinol en AZA, zonder de dosis van AZA met $75 \%$ te verlagen, is gevaarlijk eveneens met het $00 \mathrm{~g}$ op beenmergschade.

De dosis azathioprine die aan RA patiënten wordt gegeven, varieert tussen de 1.5 en 2.5 $\mathrm{mg} / \mathrm{kg}$ lichaams-gewicht/dag. De meest frequent voorkomende bijwerkingen van AZA zijn gastro-intestinale complicaties en leucopenie. Bijwerkingen die minder frequent voorkomen zijn hepatotoxiciteit, allergische reacties en hematologische complicaties zoals anemie, trombopenie of pancytopenie.

In Hoofdstuk 3 passeert methotrexaat de revue. MTX is een antagonist van foliumzuur afhankelijke enzymen, waarvan dihydrofolaat reductase (DHFR) de belangrijkste is. Foliumzuur afhankelijke enzymen zijn betrokken in de DNA en RNA synthese. De werking van MTX bij RA is, ondanks veel onderzoek, nog slechts ten dele bekend. De aanbevolen dosis MTX bij RA varieert tussen de 7,5 en $15 \mathrm{mg}$ per week in één dosis, of verdeeld in drie doses om de 12 uur. In-vivo en in-vitro gegevens bij mens en dier doen vooral anti-inflammatoire maar ook immuunmodulerende en antiproliferatieve eigenschappen van MTX vermoeden. MTX wordt omgezet in MTX-polyglutamaten, welke vooral in de lever worden aangetroffen. Onderzoek heeft aangetoond, dat er geen cumulatie ontstaat van MTX-polyglutamaten in de lever bij RA patiënten, die behandeld worden met een lage dosis methotrexaat.

MTX wordt voomamelijk via de nier uitgescheiden. Een verminderde nierfunctie (klaring $<50 \mathrm{ml} / \mathrm{min}$ ) geeft meer kans op bijwerkingen. De concentratie van MTX in de synoviale vloeistof komt vrijwel overeen met die in het serum. Het gelijktijdig toepassen van NSAIDs en een lage dosis MTX veroorzaakt zelden bijwerkingen bij RA patiënten. Er bestaat een verhoogde kans op beenmergschade, indien gelijktijdig met MTX, andere foliumzuur antagonisten zoals trimethoprim-sulfamethoxazol (co-trimoxazol) worden voorgeschreven. Aangezien MTX teratogene eigenschappen heeft, is adequate contraceptie tijdens toepassing van dit middel absoluut vereist. 
MTX blijkt bij RA patiēnten significant effectiever te zijn dan placebo. Uit vergelijkingsstudies blijkt verder, dat MTX ten opzichte van andere tweedelijns antireumatica op zijn minst even effectief is. In vergelijking met oraal goud (ridaura) heeft MTX klinisch meer effect en is minder toxisch. Het percentage patiēnten dat na 5 jaar nog MTX gebruikt $( \pm 50 \%)$ is veel hoger dan het percentage dat gevonden wordt voor andere tweedelijns antireumatica $( \pm 20 \%)$.

De meest frequent voorkomende bijwerkingen van MTX zijn verhoogde waarden van leverenzymen en gastro-intestinale bijwerkingen. Minder frequent voorkomende bijwerkingen zijn ulcera in de mond en hematologische en pulmonale complicaties (pneumonitis). Uit onderzoek is gebleken, dat de toevoeging van een lage dosis foliumzuur ( $1 \mathrm{mg}$ /dag) minder bijwerkingen veroorzaakt, zonder het klinisch effect van MTX bij RA te beïnvloeden.

Ervaring met ruim $800 \mathrm{RA}$ patiēnten heeft aangetoond, dat ernstige, histologisch bevestigde hepatotoxiciteit (cirrose) zeer zelden voorkomt na een cumulatieve dosis van 1.5-2.0 gram MTX. In de reumatologische literatuur bestaat er communis opinio om geen leverbiopsieën meer te doen vóór het starten van MTX bij RA, tenzij er risicofactoren zijn. Er bestaat veel discussie omtrent de noodzaak tot het doen van "post-MTX" leverbiopsieën na een cumulatieve dosis van 1.5-2.0 gram, met name in de groep van patiënten die geen risicofactoren bezitten (zoals geen of nauwelijks alcohol gebruik en geen pre-existente leverziekte). De ervaring met MTX bij RA patiënten op langere termijn is echter nog te gering om definitief leverbiopsieën uit het controle schema te schrappen.

In Hoofdstuk 4 komt het gebruik van MTX bij de verschillende collageenziekten aan de orde. Na gegevens over de historie van MTX en diermodel studies bij MTX, volgt aanvullende informatie op hoofdstuk 3 over de farmacologie en farmacokinetiek van MTX, naast hypothesen over het werkingsmechanisme van MTX bij RA. Wat betreft de klinische toepassing van MTX bij collageenziekten, is de ervaring bij poly- en dermatomyositis het grootst, en veelal gunstig. De ervaring met MTX bij vasculitis, sclerodermie, en systemische lupus erythematosus (SLE) is beperkt, maar biedt perspectieven. In dit hoofdstuk komen tevens de belangrijkste risicofactoren voor het gebruik van MTX (met name alcohol gebruik) alsmede mechanismen van geneesmiddelen interacties met MTX (competitie met tubulaire secretie, verdringing van eiwitbinding, additief foliumzuurantagonisme) aan de orde. Verder worden aanvullende gegevens vermeld ten aanzien van de bijwerkingen van MTX. Tenslotte worden nog aanbevelingen gedaan voor een controleschema, welke gehanteerd kan worden bij de toepassing van MTX.

Hoofdstuk 5 bevat de klinische resultaten van een 1 -jarige open studie, waarbij 16 patiënten met actieve, therapieresistente RA behandeld werden met een lage dosis MTX (7,5-15 mg/week). Eerdere therapie met 4 andere antireumatische middelen, te weten hydroxychloroquine, parenteraal goud, D-penicillamine en azathioprine, had bij deze patiënten gefaald. Alle patiënten gebruikten voor en tijdens de studie NSAIDs. Acht van hen waren reeds voor de start van de studie ingesteld op prednison ( $\leq 10 \mathrm{mg} / \mathrm{dag}$ ). Het eerste half jaar vonden maandelijks klinische metingen en laboratoriumcontroles plaats; in 
het tweede half jaar vonden de controles elke 2 maanden plaats.

Twee patienten werden van analyse uitgesloten in verband met het vroege ontstaan van bijwerkingen (respectievelijk diarree na 2 weken en depressie na 2 maanden). Bij 12 van de 14 resterende patiënten bleek er na 2 maanden een significante verbetering te zijn ontstaan in 5 klinische graadmeters [ochtendstijfheid, het aantal pijnlijke en gezwollen gewrichten, de score voor pijn en algemeen welbevinden $(0-10 \mathrm{~cm}$ schaal)], naast verbetering van een aantal laboratorium graadmeters [bezinking, C-reactieve proteine (CRP), en de Immunoglobulines $A, M$, en $G$ ]. De klinische verbetering nam in de periode tussen de $2^{\circ}$ en $6^{\mathrm{C}}$ maand toe, maar bereikte hierna een plateau fase. Dit betekende dat er vanaf de $6^{c}$ tot de $12^{c}$ maand nauwelijks verdere verbetering optrad. De helft van de patiënten kreeg te maken met bijwerkingen, meestal van gastro-intestinale aard ofwel in de vorm van verhoogde waarden van leverenzymen. Deze bijwerkingen waren vrijwel altijd van milde aard en verdwenen na tijdelijk stoppen of verlagen van de dosis MTX.

Samenvattend bleek uit deze studie, dat MTX bij patiënten met therapieresistente RA een effectief geneesmiddel was.

In Hoofdstuk 6 worden de klinische resultaten van een dubbelblinde studie tussen MTX en AZA bij RA uitvoerig beschreven. Het betrof 64 patiënten (33 AZA; 31 MTX) met actieve RA, die onvoldoende gereageerd hadden op, of bijwerkingen kregen van behandeling met parenteraal goud. Driekwart van hen was ook zonder succes behandeld met hydroxychloroquine en driekwart tevens met D-penicillamine. Alle patiēnten voldeden aan een 4-tal insluitcriteria voor actieve RA. Patiënten kregen of 7,5 mg MTX per week of $100 \mathrm{mg}$ AZA per dag. Afhankelijk van het klinisch resultaat na 8 weken, werd de dosis verhoogd naar respectievelijk $15 \mathrm{mg}$ MTX en $150 \mathrm{mg}$ AZA. De doses prednison en NSAIDs werden tijdens de studie en 4 weken voor de start van de studie stabiel gehouden.

De klinische resultaten werden beoordeeld zowel voor de patiëntengroepen die na 24 en 48 weken nog steeds hetzelfde medicament (dwz of AZA of MTX) gebruikten, als ook volgens een "intention-to-treat methode", dwz onafhankelijk van het feit of patiënten een ander tweedelijns middel dan AZA of MTX kregen. Naast vergelijking van uitslagen na 24 en 48 weken met de gegevens aan het begin van de studie, werd voor de periode tussen 0 en 24 weken ook de oppervlakte onder de curve van de belangrijkste graadmeters van ziekteactiviteit berekend. Tenslotte werd nog de procentuele verbetering van deze graadmeters en een samengestelde, gevalideerde ziekte-index [de zogenaamde DAS (=disease activity score)] van 4 graadmeters berekend.

Uit het onderzoek kwam naar voren, dat er geen significante verschillen in demografische en klinische gegevens waren tussen beide patiēntengroepen. Verdere berekening toonde aan, dat 12 van 13 klinische- en laboratoriumgraadmeters in de MTX groep significant na 24 weken verbeterden. In de AZA groep verbeterden 6 van 13 graadmeters. Uit analyse (oppervlakte onder de curve) bleek tevens, dat patiënten uit de MTX groep significant meer verbetering lieten zien in de volgende 7 graadmeters: pijnscore (0$10 \mathrm{~cm}$ schaal), aantal gezwollen gewrichten, bezinking (BSE), CRP, hemoglobine, trombocyten en de DAS. Een intention-to-treat analyse na 24 weken leverde een gelijksoortig resultaat op met uitzondering van het aantal gezwollen gewrichten. $\mathrm{Na} 48$ weken waren 
er geen significante verschillen tussen beide groepen meer aantoonbaar. Het aantal patiënten met een significant verbeterde DAS in de periode tussen 0 en 24 weken, was driemaal hoger in de MTX dan de AZA groep. Het aantal patiēnten dat moest stoppen vanwege bijwerkingen, was significant hoger in de AZA groep. Enstige bijwerkingen door behandeling met AZA bestonden uit gastro-intestinale (5x), cholestatische leverfunctiestoornissen $(2 x)$, overgevoeligheidsreacties $(3 x)$ en hematologische complicaties (2x).

De conclusie van deze studie was, dat MTX bij RA patiënten klinisch superieur was ten opzichte van AZA. Naast een sneller intredend effect, was het klinisch effect van MTX ook meer uitgesproken en ging gepaard met minder ernstige bijwerkingen dan AZA.

In Hoofdstuk 7 wordt de invloed van AZA en MTX op de radiologische progressie bij RA onderzocht. Het betrof dezelfde patiëntengroepen zoals beschreven in de dubbelblinde studie van hoofdstuk 6 . Röntgenfoto's van handen, polsen en vooryoeten werden aan het begin van de studie en vervolgens na 24 en 48 weken gemaakt. Deze röntgenfoto's werden gescoord volgens de gemodificeerde methode van Sharp door een ervaren reumatoloog, die niet op de hoogte was van de klinische gegevens dan wel de medicatie die de betreffende patiënten gebruikten. Vór de studie werd het verschil bij het scoren van röntgenfoto's zowel tussen de onderzoekers als "binnen" de onderzoekers beoordeeld. Hierbij werd nauwelijks enig verschil $(R=0.98)$ gevonden.

Radiologische scores werden zowel voor patiëntengroepen die gedurende 24 en 48 weken hetzelfde medicament (dwZ of AZA of MTX) gebruikten, als ook volgens een intention-to-treat methode berekend. De initiële radiologische scores tussen beide groepen verschilden nauwelijks van elkaar.

Na 24 en 48 weken bleek, dat in de patiënten die steeds MTX hadden gebruikt, er minder nieuwe erosies waren ontstaan. Dit verschil in nieuwe erosies was ten opzichte van de AZA groep na 48 weken significant. Wat betreft de totale score (=erosies + gewrichtsspleetversmalling) bleek er eveneens minder progressie in de MTX groep te zijn. Een intention-to-treat analyse liet zien, dat er significant minder nieuwe erosies en minder verandering in de totale score na 24 en 48 weken waren in de patiënten die gestart waren met MTX. Na 48 weken bleek er bij $10 \%$ van de AZA en $29 \%$ van de MTX patiēnten geen veranderingen te zijn ontstaan in reeds aanwezige afwijkingen op röntgenfoto's van handen en voeten (=radiologische stabilisatie).

De conclusie van deze studie was, dat er bij RA patiënten die gestart waren met MTX, na 1 jaar significant minder radiologische progressie was in vergelijking met patiēnten die gestart waren met AZA. Deze gunstige radiologische resultaten voor MTX hebben mogelijk te maken met het sneller intredend en krachtiger klinisch effect van MTX zoals beschreven in hoofdstuk 6 .

In Hoofdstuk 8 komen de resultaten van longfunctie-onderzoek en thoraxfoto's bij de eerder beschreven 2 patiëntengroepen aan de orde. De voomaamste vraag die we ons stelden was, of periodieke thoraxfoto's en meting van longfuncties zinvol waren voor de (vroege) detectie van eventuele MTX pneumonitis. Bovendien werd onderzocht of RA 
patiënten met reeds bestaande longafwijkingen een risicogroep vormden voor het ontwikkelen van een mogelijke MTX pneumonitis. Tenslotte was nog een bijkomende vraag of er een associatie was tussen de aanwezigheid van keratoconjunctivitis bij RA en de aanwezigheid van aandoeningen van de kleine luchtwegen (zogenaamde "small airways diseasen").

Thoraxfoto's en longfunctie-onderzoek bestaande uit spirometrie, flow volume curves, CO diffusie en compliance werden uitgevoerd aan het begin van de studie, na 6 maanden en na 2 jaar.

Longfunctietesten aan het begin van de studie, uitgevoerd bij 52 patiënten (27 AZA; 25 MTX), lieten geen significante verschillen zien tussen de twee groepen. Verder bleek dat in beide groepen, 15 tot $50 \%$ van de patiënten, een of meerdere afwijkende longfunctietesten had. Op het tijdstip van de analyse waren 35 patiënten 2 jaar vervolgd.

$\mathrm{Na} 24$ weken en 2 jaar bleken er in vergelijking met beginwaarden, geen significante verschillen in longfunctietesten te zijn noch tussen beide groepen noch binnen de twee groepen. Indien patiënten werden verdeeld in groepen met en zonder verlaagde waarden van longfunctietesten was er ook na 24 weken geen verschil aanwezig. Vergelijking tussen thoraxfoto's aan het begin van de studie met die na 2 jaar leverden geen verschillen op in beide groepen.

Patiënten met bestaande longafwijkingen (o.a longfibrose) ontwikkelden geen MTX pneumonitis. Negen patiënten (6 AZA; 3 MTX) hadden keratoconjunctivitis sicca (KCS). Een associatie tussen KCS en aandoeningen van de kleine luchtwegen, zoals beschreven in de literatuur, kon worden bevestigd. Vrijwel al deze patiënten waren positief voor het humaan leucocyte antigeen (HLADR4) en hadden subcutane noduli.

Concluderend bleek dat longfunctietesten en thoraxfoto's van RA patiēnten niet veranderden na 24 weken en 2 jaar behandeling met AZA of MTX. Bij patiēnten met reeds bestaande longafwijkingen werd geen MTX pneumonitis gevonden. Met het oog op het voorkomen van MTX pneumonitis $( \pm 3-5 \%$ ) is het aanbevelenswaardig om (beperkt) longfunctie onderzoek te doen (spirometrie en $\mathrm{CO}$ diffusie) en een thoraxfoto te maken voor het starten van behandeling met MTX. Herhaald onderzoek van longfunctie en thoraxfoto lijkt op grond van deze studie alleen nodig indien het klinisch beeld daartoe aanleiding geeft. Studies met een langere vervolgduur en een groter aantal patiēnten zijn echter nodig om tot een definitiever advies te komen.

In Hoofdstuk 9 worden in drie publicaties een drietal zeldzame, maar potentieel gevaarlijke bijwerkingen van AZA en MTX, die tijdens deze studie ontstonden, in detail besproken en bediscussieerd.

In het eerste artikel wordt beschreven, hoe binnen 3 weken pancytopenie ontstond tijdens behandeling met AZA. In verband met een ernstige trombopenie werd de betreffende patiënt opgenomen en kreeg trombocytenconcentraat toegediend. Bij een tweede patiënt (geen trial patiënt) ontstond pancytopenie tijdens gecombineerde behandeling van AZA en allopurinol.

In het tweede artikel worden drie patiēnten beschreven bij wie de volgende bijwerkingen ontstonden binnen 2 weken na starten van AZA: bij de eerste patiënt koorts met koude rillingen en cholestatische leverafwijkingen, bij de tweede, koorts, huiduitslag, 
diarree en leverfunctiestoornissen en bij de derde patiënt zeer hoge koorts en heftige koude rillingen. Bij de eerste patiënt waren de leverfuncties pas na 7 maanden genormaliseerd.

In een derde artikel wordt een patiënt gedemonstreerd, bij wie plotseling vele reumanoduli ontstonden tijdens behandeling met MTX. Na 3 maanden behandeling met MTX kreeg deze patiēnt noduli op vele, vaak ongebruikelijke plaatsen zoals knieên, wervelkolom en wenkbrauwen. Er volgde opname toen deze noduli ontstoken raakten en er vasculitis verschijnselen op de voeten waren verschenen. Na het staken van de MTX verdwenen de noduli en vasculitis binnen vier weken.

Pancytopenie bij 2 patiënten (beiden niet afkomstig uit de trial) wordt tenslotte beschreven in een vierde artikel van dit hoofdstuk. De pancytopenie ontstond door de gelijktijdige toepassing van MTX en andere foliumzuurantagonisten (trimethoprim en trimethoprim-sulfamethoxazole). 



\section{DANKWOORD}

Meer dan ik ooit voor mogelijk heb gehouden, zijn veel mensen bij de uiteindelijke totstandkoming van dit proefschrift betrokken geweest. Ik wil daarom al degenen die mij op enigerwijze geholpen hebben, langs deze weg nog eens hartelijk bedanken. In de eerste plaats ben ik alle patiënten, die aan het onderzoek hebben meegewerkt, zeer erkentelijk. Zonder in cliche's te vervallen is het zeker zo, dat zonder uw medewerking, inzet en trouwe bezoek aan de poliklinieken, dit onderzoek volstrekt onmogelijk was geweest. Verder wil ik, in willekeurige volgorde, alle mensen van de deelnemende klinieken [secretaresses, personeel van diverse laboratoria (inclusief longfunctie)] bedanken voor hun gastvrijheid en hulp. Jullie stonden steeds klaar om, indien nodig, onderzoek met voorrang te verrichten, statussen te zoeken etc. Ook telefoontjes of vragen over (achtergebleven) uitslagen waren nooit teveel. De verwerking en bepaling van de vele serummonsters, met name die van Complement C3, C4, C1q en de APF waren in goede handen van Gertie Vierwinden en Ans van Erp.

Een woord van dank gaat zeker uit naar de collega's J. Rasker en M. Kruijsen uit Enschede, H. van Beusekom en W. Hissink Muller uit Tilburg, J. Haverman uit Den Bosch, M. Franssen en DJ. de Rooy uit Nijmegen (St Maartenskliniek) en alle collega's van de afdeling reumatologie van het St Radboudziekenhuis, die de tijd en ruimte vonden om eventuele geschikte trialpatiënten aan mij voor te dragen. Toon Westgeest maakte al een aanvang met het eerste ontwerp van de trial- en laboratoriumformulieren en organiseerde de opslag van de serummonsters.

Voor de statistische ondersteuning stonden J. Mulder en W. Doesburg altijd klaar. Beste Jan, uit de enorme vracht aan gegevens wist je met mijn vele vragen uiteindelijk steeds de juiste zaken uit de computer te halen. De vele kilo's computervellen getuigen van je inzet. Beste Wim, het was mij een genoegen om met je te discussiëren over de resultaten van het onderzoek. Elk moment van de dag kon ik even overleggen. Je hebt constructief meegedacht en veel tijd besteed aan de statistische analyse van de belangrijkste artikelen.

Het vele typewerk werd aanvankelijk door Marion Janssen gedaan. Beste Marion, bedankt voor de zorg en de tijd die je eraan besteedde. Het was vaak "passen en meten" om tussendoor iets te typen. Toen het teveel tijd ging vergen, nam Bianca Schippers het "roer" over. Beste Bianca, bedankt voor het vele typewerk, je inzet en je geduld. Ik kon altijd langskomen voor veranderingen van teksten, zelfs toen je hand in het gips zat.

De vriendschap en collegialiteit op de afdeling reumatologie in Nijmegen heeft mij altijd zeer getroffen. Het is de basis geweest voor een uiterst plezierig werkklimaat. Beste Agnes, Leo, Alphons, Desiree, Frank, Ike, Marcel, Piet, Pit, en Roland, bedankt hiervoor. Roland, ik heb je spontane aanbod om diverse tabellen te vervolmaken zeer gewaardeerd.

Uiteraard wil ik ook mijn promotores Prof. Dr. L.B.A. van de Putte en Prof. Dr. F.W.J. Gribnau niet vergeten. Beste Leo, bedankt voor het vertrouwen dat je in mij stelde om dit onderzoek te verrichten. Je wist steeds snel en haarscherp de juiste positieve kritiek te leveren. Beste Frank, met name de hoofdstukken 2 en 3 heb je van kritisch commentaar voorzien. Je hebt mij daarbij vele nuttige suggesties aan de hand 
gedaan.

Last but not least, wil ik Dr. A.M.Th. Boerbooms bedanken. Beste Agnes, woorden schieten tekort voor de manier waarop je mij hebt begeleid. Jouw bezielende leiding, je enthousiasme en stuwende kracht waren voor mij een enorme stimulans. Bedankt voor alles wat je hebt gedaan!

De kinderen, familie, en vrienden wil ik bedanken voor hun geduld. Vaak moest ik noodgedwongen verstek laten gaan bij verjaardagen en andere feestelijke gebeurtenissen. Vooral Astrid en Linda hebben heel wat begrip moeten opbrengen. Marianne en Victor bied ik nog een glaasje "Spatie rood" aan voor hun geweldige hulp aan het eind van de rit.

Ik zou niet willen eindigen zonder mijn vrouw Wanda in de bloemetjes te zetten. Meisje, zonder jouw steun was het me nooit gelukt om zo ver te komen. Zonder enig woord van protest heb je vele, vele avonden en dagen alleen moeten doorbrengen. Vaak bood je mij aan om te helpen of iets uit te zoeken. Je typte ook daadwerkelijk menig "A4tje" en verrichtte veel noodzakelijk controlewerk. Tot het laatste toe stimuleerde je mij om door te gaan. Ook die vaak onzichtbare steun is mij meer dan dierbaar geweest! 


\section{CURRICULUM VITAE}

De schrijver van dit proefschrift, Maurice Jeurissen, werd op 31 augustus 1953 te Eindhoven geboren. Van 1965-1971 was hij leerling aan het Bernardinus College te Heerlen, waar hij in mei 1971 zijn diploma gymnasium-B behaalde.

Van september 1971 tot november 1972 studeerde hij Tandheelkunde aan de Katholieke Universiteit te Nijmegen. Aan dezelfde Universiteit begon hij in januari 1973 met de studie Geneeskunde. Op 18 mei 1979 werd het artsexamen behaald.

Van juli 1979 tot oktober 1980 was hij, in verband met zijn dienstplicht, als controleen kazernearts werkzaam in de Brederode kazeme te Vught. Op 1 november 1980 startte hij de opleiding Interne Geneeskunde in het Grootziekengasthuis te 's Hertogenbosch (opleiders Dr. J. Lips en Dr. J. Jansen). Hij werd op 1 januari 1986 ingeschreven als internist.

Vervolgens maakte hij op 1 maart 1986 een aanvang met de opleiding tot reumatoloog in het St Radboudziekenhuis te Nijmegen (opleider Prof. Dr. L.B.A van de Putte). In april 1987 begon hij met zijn promotie-onderzoek, afgewisseld door klinische- en poliklinische werkzaamheden. In september 1990 volgde zijn registratie als reumatoloog. Vanaf 1 oktober 1990 is hij als reumatoloog werkzaam in het ziekenhuis de Gelderse Vallei (locaties Wageningen, Veenendaal, Bennekom, Ede) en in het ziekenhuis Rijnstate te Amhem, in associatie met twee collegae reumatologen.

Maurice Jeurissen is gehuwd met Wanda Simons. Zij hebben twee dochters, Linda en Astrid. 



\section{STELLINGEN}

behorende bij het proefschrift

\section{METHOTREXATE VERSUS AZATHIOPRINE IN RHEUMATOID ARTHRITIS}

Maurice Jeurissen

Nijmegen, 2 december 1991 
1. Methotrexaat in een dosis van $7.5-15 \mathrm{mg}$ per week is bij veel patiēnten met reumatoide artritis eerder werkzaam, effectiever, en leidt tot minder ernstige bijwerkingen dan behandeling met azathioprine.

(Dit proefschrift)

2. Methotrexaat is, vergeleken met azathioprine, meer in staat om het proces van radiologische progressie bij reumatoide artritis af te remmen.

Lage dosis methotrexaat kan dan ook met recht gerekend worden tot de DMARD's = disease modifying antirheumatic drugs.

(Dit proefschrift)

3. Het voorschrijven van allopurinol in combinatie met azathioprine, zonder de dosis van azathioprine drastisch aan te passen, kan ernstige gevolgen hebben.

(Dit proefschrift)

4. De kans dat een cumulatieve dosis van 1.5-2 gram methotrexaat bij reumatoide artritis, met name bij patiēnten zonder risicofactoren, irreversibele leverschade veroorzaakt, is erg klein. In hoeverre dit ook geldt voor hogere doses methotrexaat is nog onvoldoende bekend.

(Dit proefschrift)

5. "You can not teach an old dog new tricks", gaat niet op voor het al uit 1947 stammende medicijn methotrexaat. Voor de dosis gebruikt bij reumatoide artritis zou kunnen gelden: "You can teach an old drug superior tricks".

6. Preēxistente longafwijkingen bij patiēnten met reumatoide artritis zijn geen contraindicatie voor behandeling met methotrexaat.

(Dit proefschrift)

7. Het gelijktijdig voorschrijven van methotrexaat en andere foliumzuur antagonisten zoals sulfapreparaten, kan de kans op beenmerg depressie aanzienlijk verhogen.

(Dit proefschrift)

8. Het nog steeds gebruiken, anno 1991, van woorden als malaria (mal, slecht; aer, lucht) en arteria (aer, lucht; terrere, dragen) getuigt van weinig modem inzicht in de ontstaanswijze van malaria of fysiologie van de bloedcirculatie. Reeds Galenus (200 n. Chr.) ontzenuwde de mening dat slagaders bij het leven lucht zouden bevatten en na de dood leeg zouden zijn!

9. Men weet eigenlijk slechts zolang men nog weinig weet; hoe meer men weten gaat, hoe meer men gaat twijfelen. 
10. Bij leucocytose in combinatie met een verhoogde bezinking en een in korte tijd ontstane plankharde zwelling in het bovenbeen, dient in de eerste plaats aan pyomyositis gedacht te worden.

(Eigen waameming)

11. Wie tevreden is over zijn arbeid, heeft reden tot ontevredenheid over zijn tevredenheid

(Multatuli)

12. De verspreking "methotractatie", gehoord uit de mond van een reumapatiènt, wekt de verkeerde indruk dat methotrexaat het "snoepje van de week" zou zijn. 


4 